Márcio Fontana Catapan

Christian Scapulatempo Strobel

Fábio Evangellista Santana

\title{
Desenho técnico no contexto das engenharias
}

$1^{\circ}$ Ediçä̀o

São José dos Pinhais

BRAZILIAN JOURNALS PUBLICAÇÕES DE PERIÓDICOS E EDITORA

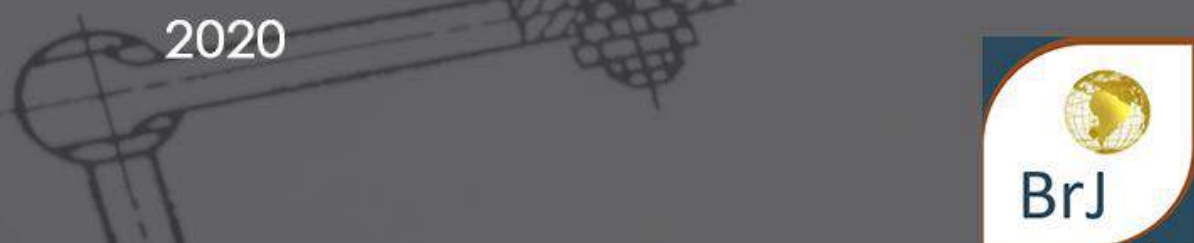




\section{Desenho técnico no contexto das engenharias}

$1^{\circ}$ Edição

\section{Brazilian Journals Editora} 2020 


\author{
2020 by Brazilian Journals Editora \\ Copyright (C) Brazilian Journals Editora \\ Copyright do Texto (C) 2020 Os Autores \\ Copyright da Edição (C) 2020 Brazilian Journals Editora \\ Editora Executiva: Barbara Luzia Sartor Bonfim \\ Diagramação: Sabrina Binotti \\ Edição de Arte: Sabrina Binotti \\ Revisão: Os Autores
}

O conteúdo dos artigos e seus dados em sua forma, correção e confiabilidade são de responsabilidade exclusiva dos autores. Permitido o download da obra e o compartilhamento desde que sejam atribuídos créditos aos autores, mas sem a possibilidade de alterá-la de nenhuma forma ou utilizá-la para fins comerciais.

\title{
Autores:
}

Márcio Fontana Catapan

Christian Scapulatempo Strobel

Fábio Evangelista Santana

Brazilian Journals Editora

São José dos Pinhais - Paraná - Brasil

www.brazilianjournals.com.br

editora@brazilianjournals.com.br 


\section{APRESENTAÇÃO}

A arte de representar um objeto ou fazer sua leitura por meio do desenho técnico é tão importante quanto à execução de uma tarefa. Esse fato é devido que o desenho tem a necessidade de fornecer todas as informações precisas e necessárias para a construção de uma peça/produto.

Visando abordar a maioria dos assuntos relativos ao desenho técnico de forma sucinta, porém completa em uma disciplina de cursos de graduação compostas de 45 a 60 horas, esta apostila foi elaborada. A experiência de 20 anos nesta área, tanto atuando como profissional do ramo de engenharia mecânica, como professor universitário, capacitaram os autores a construir um material que propiciasse tal dinâmica de aprendizagem.

Para isso, esta apostila foi dividida no conteúdo de introdução ao Desenho Técnico e Desenho, onde abordará os conceitos básicos para o seu entendimento.

Na primeira parte, dentro do escopo do curso e respeitando as limitações de tempo disponível para o ensino de desenho técnico, num curso de graduação, praticamente todos os conhecimentos básicos necessários para a realização de um desenho serão abordados.

$\mathrm{Na}$ segunda parte da apostila, os conhecimentos adquiridos na primeira são aplicados para a realização de desenhos bidimensionais e tridimensionais, com instrumentos. Essa parte consiste basicamente no aprendizado do uso de instrumentos para aplicação dos conhecimentos de desenho técnico da primeira parte do curso.

Se você trabalhar com dedicação, conseguirá atingir todos os objetivos propostos em ambas as partes.

Bom trabalho! 


\section{SUMÁRIO}

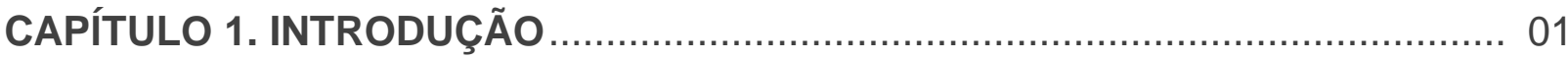

CAPÍTULO 2. NORMAS PARA DESENHO TÉCNICO - ABNT/DIN ...................... 07

CAPÍTULO 3. FORMATOS PADRÕES DE FOLHAS …....................................... 09

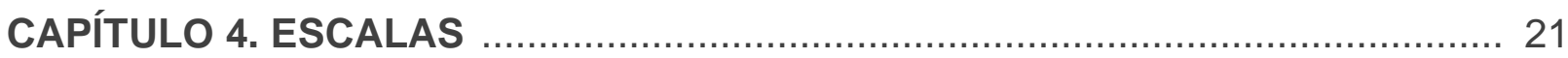

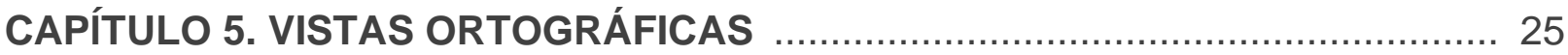

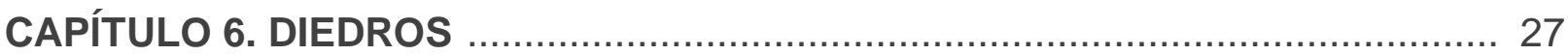

CAPÍTULO 7. COTAGEM EM DESENHO TÉCNICO - NBR $10126 \ldots \ldots \ldots \ldots \ldots \ldots \ldots \ldots . . . . . . \ldots 2$

CAPÍTULO 8. SÓLIDOS GEOMÉTRICOS ………......................................... 79

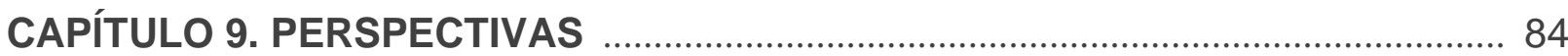

CAPÍTULO 10. PERSPECTIVA ISOMÉTRICA DE MODELOS COM ELEMENTOS CIRCULARES E ARREDONDADOS ....................................................... 98

CAPÍTULO 11. PERSPECTIVA ISOMÉTRICA DE MODELOS COM ELEMENTOS

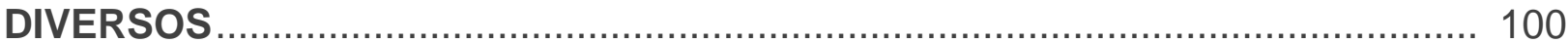

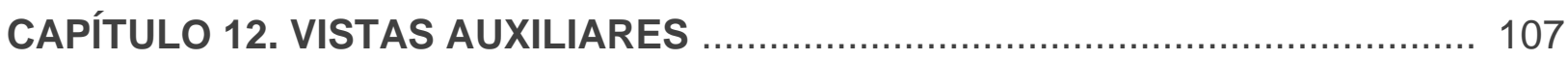

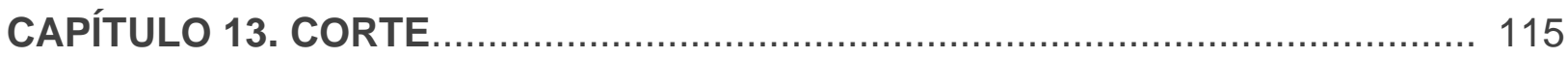

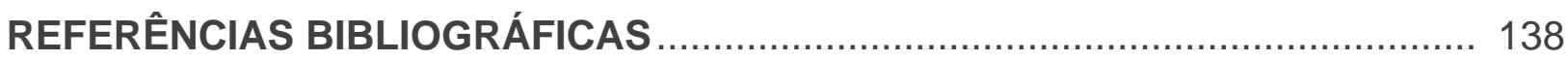

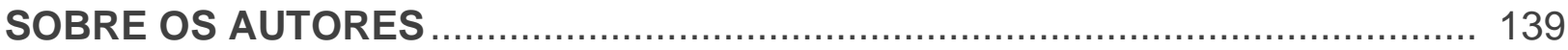

DOI 10.35587/brj.ed.000057 


\section{CAPÍTULO 1}

\section{INTRODUÇÃO}

\subsection{ETIMOLOGIA}

O português desenho é um substantivo deverbal do verbo desenhar, que remonta ao latim designare, "marcar, notar, traçar, desenhar; indicar, designar; dispor, ordenar, regular, imaginar", étimo do italiano desegnare. O português desenhar (e desenho) é modernamente só "traçar (e traçado) com linhas e afins".

Desenho é qualquer representação gráfica - colorida ou não - de formas. Desenho é a expressão gráfica da forma, não se pode desenhar sem conhecer as formas a serem representadas.

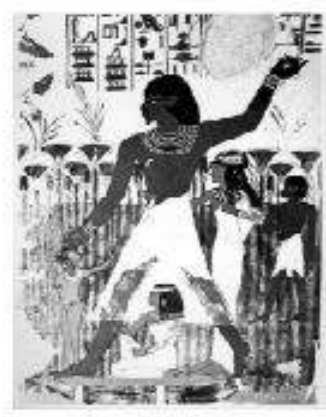

HIERÓGLIFOS

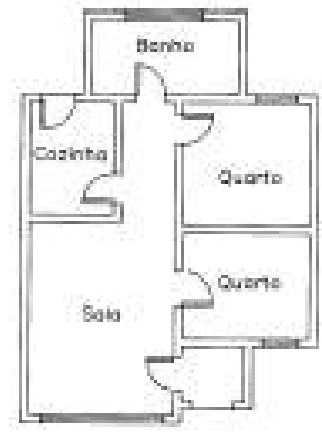

PLANTA BAIXA

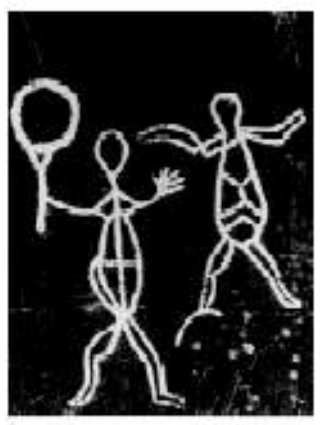

DESENHO PRIMITIVO

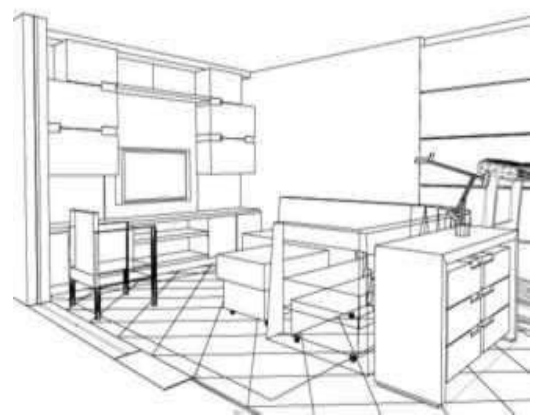

PERSPECTIVA EXATA

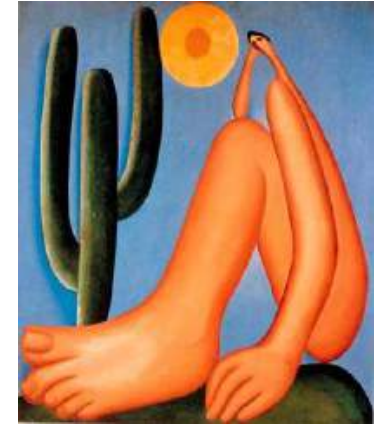

ARTE MODERNA
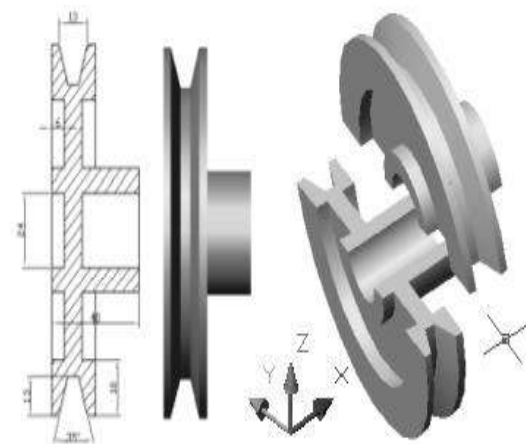

DESENHO TÉCNICO 
O desenho é a forma de comunicação mais importante, depois da palavra, o desenho serve à propaganda, ao humorismo, à arquitetura, à expressão gráfica da palavra, etc..

É um erro se considerar o desenho como uma cópia de formas, pois ele pode representar a imaginação de uma forma não existente (fiç̧ão científica): afinal, pode-se considerar desenho tudo aquilo que a mão humana traduz quando quer exprimir uma idéia mesmo que não o consiga.

Desenho Industrial - tradução da expressão inglesa industrial design significa tradicionalmente o desenho, o projeto de objetos ou de sistemas de objetos industrializados normalmente fruídos na existência cotidiana, no lar, no trabalho, no lazer: do relógio de pulso, aos talheres, da bicicleta ao automóvel, do trem ao avião, dos eletrodomésticos aos instrumentos de escritório, dos móveis aos barcos, das ferramentas manuais à máquinas operatrizes. Todos esses objetos estão fundamentados num momento projetivo - de desenho criador - e num momento iterativo - de produção em série e mecanizada.

Assim, Desenho Técnico Mecânico é o projeto da forma de objetos destinados à fabricação de objetos em série. O Projetista Mecânico (Mechanical Designer) é responsável pela forma dos produtos da sua empresa e sociedade; por isso deve considerar no seu trabalho a complexidade de relações entre produto, máquinas/equipamentos e ambiente, produto e usuário, isto é, fatores tecnológicos, econômicos, sociais e culturais do ambiente.

\subsubsection{CONCEITO}

O que é Desenho Técnico? O desenho técnico, como citado anteriormente, é uma linguagem gráfica utilizada na indústria. Para que esta linguagem seja entendida no mundo inteiro, existe uma série de regras internacionais que compõem as normas gerais de desenho técnico, cuja regulamentação no Brasil é feita pela ABNT - Associação Brasileira de Normas Técnicas.

É derivado da Geometria descritiva, que é a ciência que tem por objetivo representar no plano (folha de desenho, quadro, etc.) os objetos tridimensionais, permitindo desta forma a resolução de infinitos problemas envolvendo qualquer tipo de poliedro, no plano do papel.

O desenho técnico é um desenho operativo, ou seja, após sua confecção segue-se uma operação de fabricação e/ou montagem. Desta forma, para 
fabricarmos ou montarmos qualquer tipo de equipamento ou construção civil, em todas as áreas da indústria, sempre precisaremos de um desenho técnico.

\subsection{FINALIDADE}

Ao iniciar o estudo de Desenho Técnico, você está empreendendo uma experiência educacional gratificante que terá real valor em sua futura profissão. Quando você tiver se tornado perito nesse estudo, terá a seu dispor um método de comunicação usado em todas as áreas da indústria técnica, uma linguagem sem igual para a descrição acurada de objetos sólidos.

O desenho técnico é um dos mais importantes ramos de estudo em uma escola técnica, porque é à base de todos os projetos e subseqüentes fabricações. Todo estudante técnico deve saber fazer e ler desenhos. O desenho é essencial em todos os tipos de engenharia prática, e deve ser compreendido por aqueles relacionados com, ou interessados na indústria técnica. Todos os projetos e instruções para fabricação são preparados por desenhistas, escritores profissionais da linguagem, mas mesmo alguém que nunca tenha feito projetos deve ser capaz de lê-los e entendê-los, ou será, profissionalmente, um leigo.

A nossa finalidade é estudar a linguagem do desenho técnico, de tal maneira que se possa escrevê-la, de uma maneira clara, a alguém que, familiarizado com este assunto, possa lê-la prontamente quando escrita por outro alguém para tanto, é preciso conhecer sua teoria e composição básica e ficar a par das abreviaturas e convenções adotadas.

A finalidade principal do Desenho Técnico é a representação precisa, no plano, das formas do mundo material e, portanto, tridimensional, de modo a possibilitar a reconstituição espacial das mesmas.

Essa representação de formas constitui o campo do chamado "desenho projetivo"; o Desenho Técnico também abrange a representação gráfica de cálculos, leis e dados estatísticos, por meio de diagramas, ábacos, e nomogramas, que pertencem ao campo do "desenho não projetivo".

Por serem seus princípios fundamentalmente os mesmos em todo o mundo, alguém treinado nestas práticas em uma nação pode prontamente adaptar-se às de uma outra nação qualquer.

Esta linguagem é completamente gráfica e escrita, e é interpretada pela aquisição de um conhecimento visual do objeto representado. O êxito de um aluno 
nesta matéria será indicado não somente pela sua habilidade na execução, mas também pela sua capacidade de interpretar linhas e símbolos e visualizá-los claramente no espaço.

\subsection{IMPORTÂNCIA}

O Desenho Técnico constitui-se no único meio conciso, exato e inequívoco para comunicar a forma dos objetos; daí a sua importância na tecnologia, face à notória dificuldade da linguagem escrita ao tentar a descrição da forma, apesar a riqueza de outras informações que essa linguagem possa veicular.

Diante da complexidade dos problemas relativos aos projetos de Engenharia e Arquitetura, poderia parecer excessiva a importância atribuída à forma e à sua representação. Ocorre que a forma não é um acessório nos problemas de tecnologia, mas faz parte intrínseca dos mesmos.

O Desenho Técnico, ao permitir o tratamento e a elaboração da forma de modo fácil econômico, participa decisivamente das três fases da solução daqueles problemas.

Essas três fases são:

$1^{\circ}$ - A busca de conceitos e idéias que pareçam contribuir para a solução.

$2^{2}$ - O exame e análise crítica desses conceitos, quando alguns são escolhidos e outros rejeitados.

$3^{0}$ - O desenvolvimento dos conceitos escolhidos, seu aperfeiçoamento final e comunicação.

Portanto, as aplicações do Desenho Técnico não se limitam à fase final de comunicação dos projetos de Engenharia e Arquitetura, mas ainda cumpre destacar sua contribuição fundamental nas fases anteriores, de criação e de análise dos mesmos.

Adicionalmente, face à dificuldade em concebermos estruturas, mecanismos e movimentos tridimensionais, o Desenho Técnico permite estudá-los e solucionálos eficazmente, porque permite a sua representação.

\subsection{MODALIDADES DE EXECUÇÃO}

É comum associar-se o Desenho Técnico apenas à execução precisa por meio de instrumentos (régua, compasso, esquadros, etc.), mas ele pode, também ser executado à mão livre ou por meio de computadores. Cada uma dessas 
modalidades difere apenas quanto à maneira de execução, sendo idênticos os seus princípios fundamentais.

Enquanto o "desenho instrumental" é utilizado em desenhos finais, de apresentação, de cálculos gráficos, de nomogramas, de diagramas, etc., o "esboço à mão livre" é, por excelência, o desenho do Engenheiro e do Arquiteto, pois possui a rapidez e a agilidade que permitem acompanhar e implementar a evolução do processo mental.

A presente apostila tem a finalidade de estudar os elementos básicos do Desenho Técnico Projetivo com enfoque na sua execução à mão livre. Os exercícios propostos visam não apenas treinar o aluno na execução do esboço à mão livre, mas objetivam, primordialmente, desenvolver a sua capacidade de visualização tridimensional e de representação da forma.

\subsection{COMO É ELABORADO UM DESENHO TÉCNICO}

Às vezes, a elaboração do desenho técnico mecânico envolve o trabalho de vários profissionais. O profissional que planeja a peça é o engenheiro ou o projetista. Primeiro ele imagina como a peça deve ser e depois representa suas idéias por meio de um esboço, isto é, um desenho técnico à mão livre. O esboço serve de base para a elaboração do desenho preliminar. O desenho preliminar corresponde a uma etapa intermediária do processo de elaboração do projeto, que ainda pode sofrer alterações.

Depois de aprovado, o desenho que corresponde à solução final do projeto será executado pelo desenhista técnico. O desenho técnico definitivo, também chamado de desenho para execução, contém todos os elementos necessários à sua compreensão.

O desenho para execução, que tanto pode ser feito na prancheta como no computador, deve atender rigorosamente a todas as normas técnicas que dispõem sobre o assunto.

O desenho técnico mecânico chega pronto às mãos do profissional que vai executar a peça. Esse profissional deve ler e interpretar o desenho técnico para que possa executar a peça. Quando o profissional consegue ler e interpretar corretamente o desenho técnico, ele é capaz de imaginar exatamente como será a peça, antes mesmo de executá-la. Para tanto, é necessário conhecer as normas 
técnicas em que o desenho se baseia e os princípios de representação da geometria descritiva.

\section{EXERCÍCIOS}

1) O que é Desenho Técnico?

2) Qual é a finalidade do Desenho Técnico?

3) Qual é a importância do Desenho Técnico?

4) Quais são as modalidades de execução de Desenho Técnico? 


\section{CAPÍTULO 2}

\section{NORMAS PARA DESENHO TÉCNICO - ABNT/DIN}

\subsection{ENTIDADES NORMALIZADORAS}

A seguir temos uma lista das principais entidades de normalização: ABNT - Associação Brasileira de Normas Técnicas;

ASME - Sociedade Americana de Engenharia Mecânica (American Society of Mechanical Engeering);

ASTM - Sociedade Americana para Testes e Materiais (American Society for Testing and Materials);

BS - Normas Britânicas (British Standards);

DIN - Instituto Alemão para Normalização (Deutsches Institut für Normung);

ISO - Organização Internacional para Normalização (International Organization for Standardization);

JIS - Normas da Indústria Japonesa (Japan Industry Standards);

SAE - Sociedade de Engenharia Automotiva (Society of Automotive Engeering);

\subsection{PRINCIPAIS NORMAS}

NBR 10067 - princípios gerais de representação em desenho técnico. A NBR 10067 (ABNT, 1995) fixa a forma de representação aplicada em desenho técnico. Normaliza o método de projeção ortográfica, que pode ser no $1^{\circ}$ diedro ou no $3^{\circ}$ diedro, a denominação das vistas, a escolha das vistas, vistas especiais, cortes e seções, e generalidades.

Em relação aos aspectos geométricos, a NBR 10647/89 define:

Desenho Projetivo: Desenhos resultante de projeções do objeto sobre um ou mais planos que fazem coincidir com o próprio desenho;

Vistas Ortográficas: figuras resultantes de projeções cilíndricas ortogonais do objeto, sobre planos convenientemente escolhidos, de modo a representar, com exatidão, a forma do mesmo com seus detalhes;

Perspectivas: figuras resultantes de projeção cilíndrica ou cônica, sobre um único plano, com a finalidade de permitir uma percepção mais fácil da forma do objeto. 
Outras normas NBR, são:

NBR 10068 - Folha de desenho Lay-out e dimensões - objetiva padronizar as dimensões das folhas na execução de desenhos técnicos e definir seu lay-out com suas respectivas margens e legenda.

NBR 10582 - apresentação da folha para desenho técnico - normaliza a distribuição do espaço da folha de desenho, definindo a área para texto, o espaço para desenho, etc..

NBR 13142 - desenho técnico - dobramento de cópias. Fixa a forma de dobramento de todos os formatos de folhas de desenho para facilitar a fixação em pastas.

NBR 8402 - execução de caracteres para escrita em desenhos técnicos.

NBR 8403 - aplicação de linhas em desenhos - tipos de linhas - larguras das linhas.

NBR 8196 - desenho técnico - emprego de escalas.

NBR 12298 - representação de área de corte por meio de hachuras em desenho técnico.

NBR 10126 - contagem em desenho técnico.

NBR 8404 - indicação do estado de superfície em desenhos técnicos.

NBR 6158 - sistema de tolerâncias e ajustes.

NBR 8993 - representação convencional de partes roscadas em desenho técnico.

NBR 6402 - Execução de desenhos técnicos de máquinas e estruturas metálicas.

\subsection{GRAU DE ELABORAÇÃO DOS DESENHOS TÉCNICOS}

Esboço: Representação gráfica aplicada habitualmente aos estágios iniciais de elaboração de um projeto, podendo, entretanto, servir ainda à representação de elementos existentes ou à execução de obras.

Desenho preliminar: Representação gráfica empregada nos estágios intermediários da elaboração do projeto, sujeita ainda a alterações e que corresponde ao anteprojeto.

Croqui: Desenho não obrigatoriamente em escala, confeccionado normalmente à mão livre e contendo todas as informações necessárias à sua finalidade.

Desenho definitivo: Desenho integrante da solução final do projeto, contendo os elementos necessários à sua compreensão. 


\section{CAPÍTULO 3}

\section{FORMATOS PADRÕES DE FOLHAS}

\subsection{TAMANHOS DE FOLHAS PADRONIZADAS PELA ISSO}

O primeiro tamanho é o formato A0 com dimensões de 841 X $1189 \mathrm{~mm}$, equivalente a $1 \mathrm{~m} 2$ de área, sendo que os demais formatos originam-se da bipartição sucessiva deste, conforme figura a seguir:

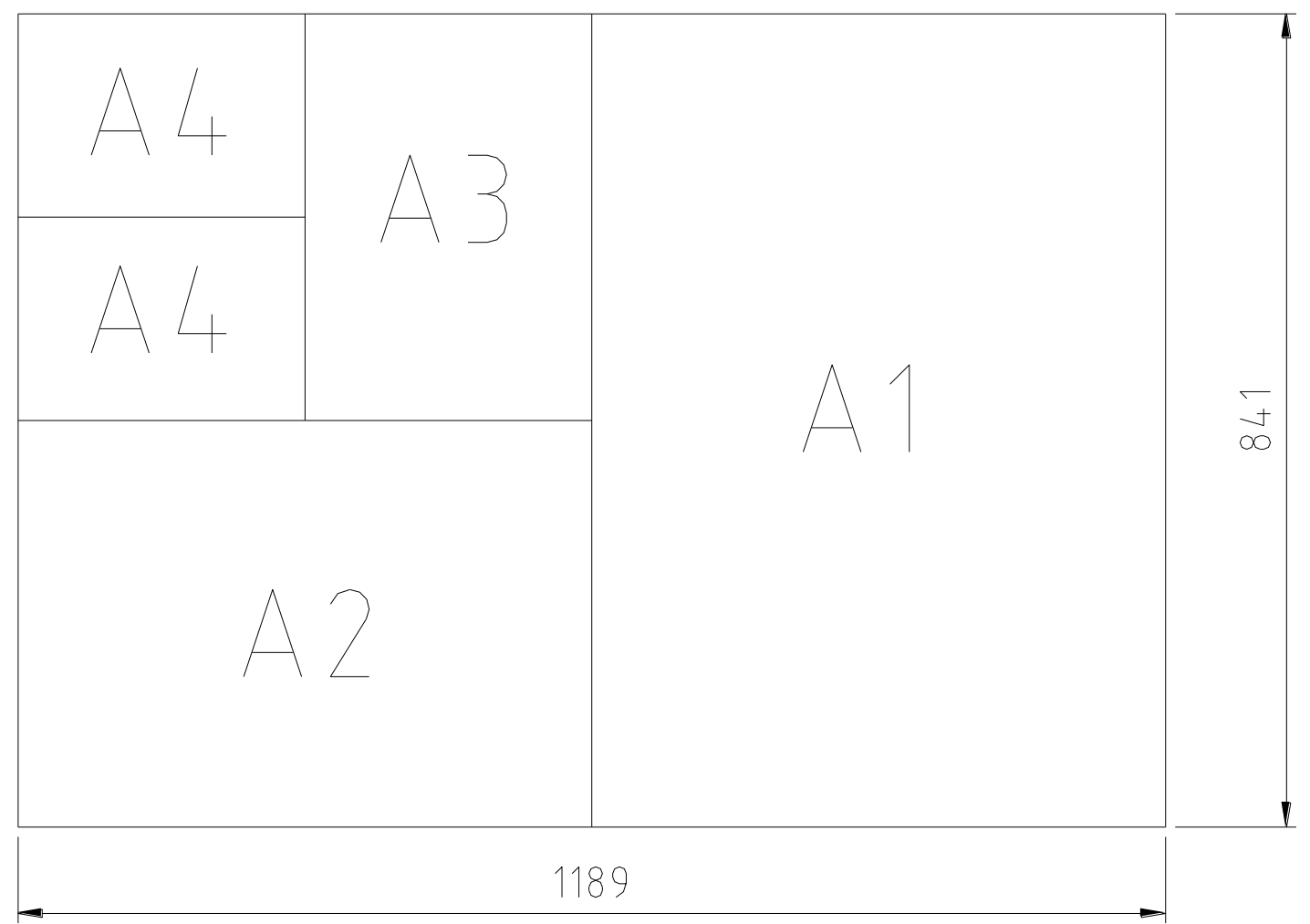

\begin{tabular}{|c|c|c|c|c|c|}
\hline \multirow[b]{2}{*}{ FORMATO } & \multirow[b]{2}{*}{ DIMENSÕES } & \multicolumn{2}{|c|}{ MARGEM } & \multirow{2}{*}{$\begin{array}{l}\text { COMPRIMENTO } \\
\text { DA LEGENDA }\end{array}$} & \multirow{2}{*}{$\begin{array}{l}\text { ESPESSURA } \\
\text { LINHAS DAS } \\
\text { MARGENS }\end{array}$} \\
\hline & & ESQUERDA & OUTRAS & & \\
\hline $\mathrm{A} 0$ & $841 \times 1189$ & 25 & 10 & 175 & 1,4 \\
\hline $\mathrm{A} 1$ & $594 \times 841$ & 25 & 10 & 175 & 1,0 \\
\hline $\mathrm{A} 2$ & $420 \times 594$ & 25 & 10 & 178 & 0,7 \\
\hline A3 & $297 \times 420$ & 25 & 10 & 178 & 0,5 \\
\hline A4 & $210 \times 297$ & 25 & 5 & 178 & 0,5 \\
\hline
\end{tabular}


Quando da necessidade de utilização de formatos fora dos padrões estabelecidos, recomenda-se a escolha destes de tal forma que a largura ou o comprimento corresponda ao múltiplo ou submúltiplo do formato padrão.

\subsection{QUADROS}

Nas dimensões das folhas deve haver um excesso de papel de $10 \mathrm{~mm}$ nos quatro lados e as margens ficam limitadas pelo contorno externo da folha e pelo quadro. $O$ quadro tem a finalidade de limitar o espaço para o desenho conforme figura abaixo.
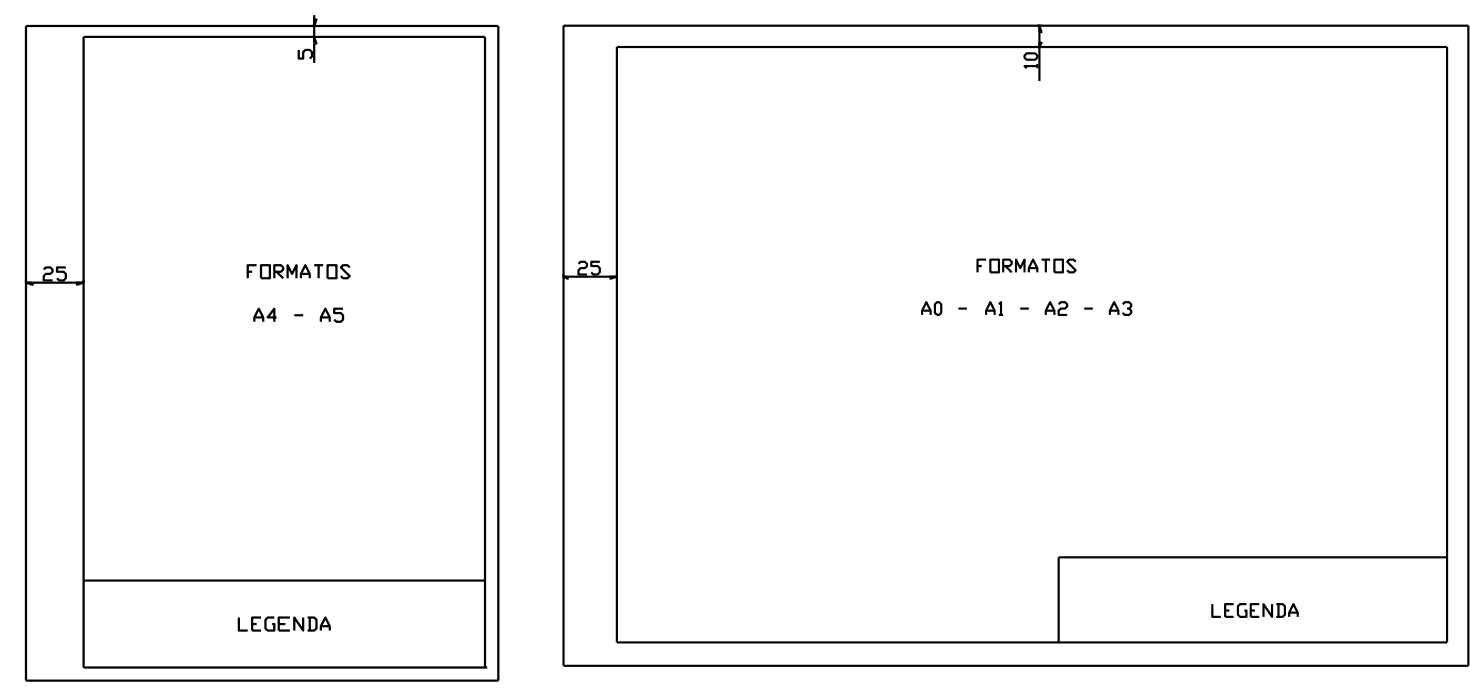

As margens são limitadas pelo contorno externo da folha e o quadro. $O$ quadro limita o espaço para o desenho (Figura abaixo).

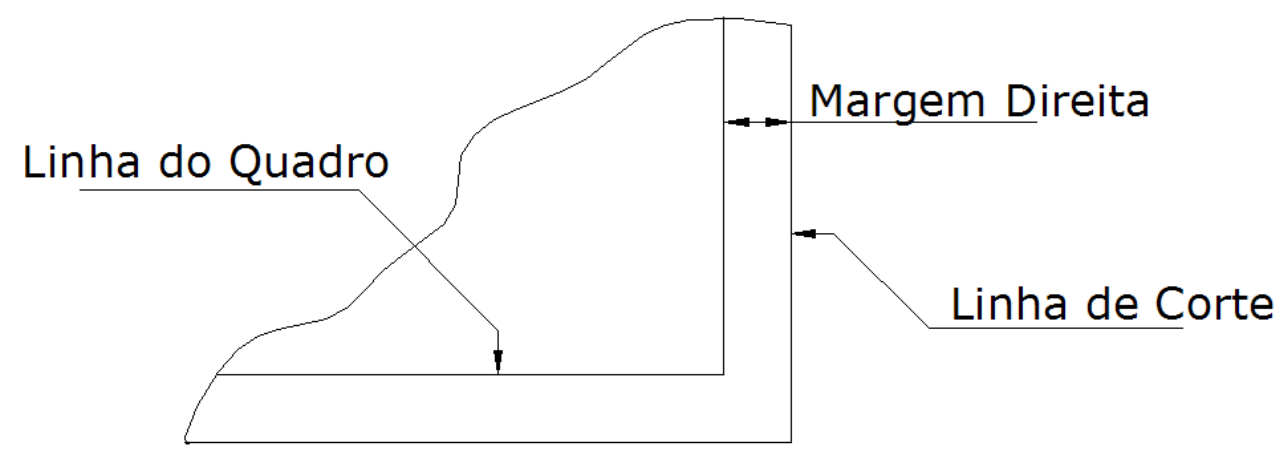




\subsection{LAYOUT DA FOLHA}

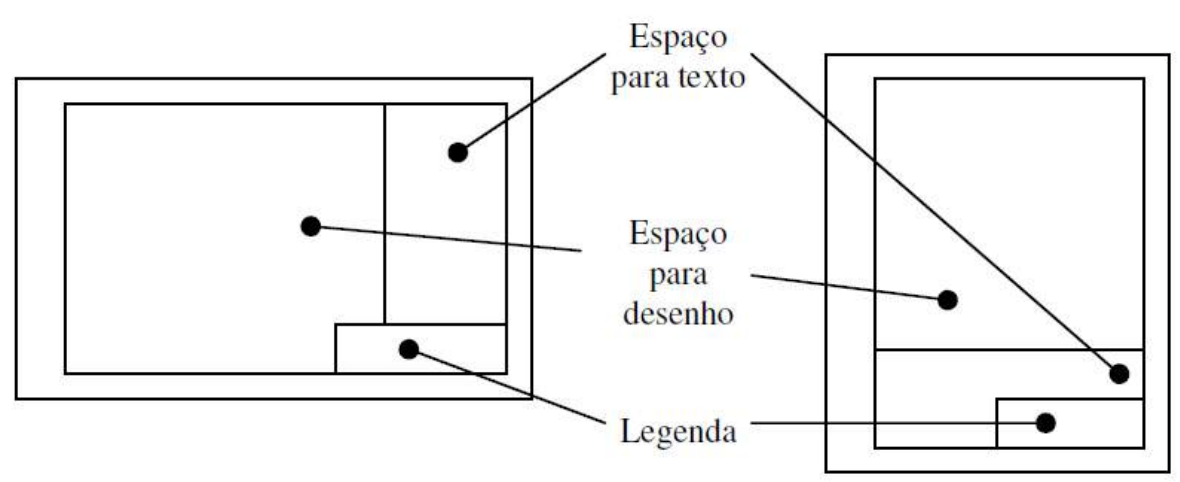

\subsection{ESPAÇO PARA DESENHO}

Os desenhos são dispostos na ordem horizontal ou vertical; a vista principal é inserida acima e à esquerda, na área para desenho.

\subsection{ESPAÇO PARA TEXTO}

Todas as informações necessárias ao entendimento do conteúdo do espaço para desenho são colocadas no espaço para texto; o espaço para texto é colocado à direita ou na margem inferior do padrão de desenho; quando o espaço para texto é colocado na margem inferior, a altura varia conforme a natureza do serviço; a largura do espaço de texto é igual a da legenda ou no mínimo 100 mm; o espaço para texto é separado em colunas com larguras apropriadas de forma que possível, leve em consideração o dobramento da cópia do padrão de desenho, conforme padrão A4; as seguintes informações devem conter no espaço para texto: explanação (identificação dos símbolos empregados no desenho), instrução (informações necessárias à execução do desenho), referência a outros desenhos ou documentos que se façam necessários, tábua de revisão (histórico da elaboração do desenho com identificação/assinatura do responsável pela revisão, data, etc).

\subsection{LEGENDAS}

A legenda deve ficar no canto inferior direito nos formatos $A 0, A 1, A 2, A 3$, ou ao longo da largura da folha de desenho no formato A4. As legendas nos desenhos industriais as informações na legenda podem ser diferentes de uma empresa para outra, em função das necessidades de cada uma. Este é o espaço destinado à informações complementares ao desenho como: identificação, número de registro, título, origem, escala, datas, assinaturas de execução, verificação e aprovação, número de peças, quantidades, denominação, material e dimensão em bruto, etc... 


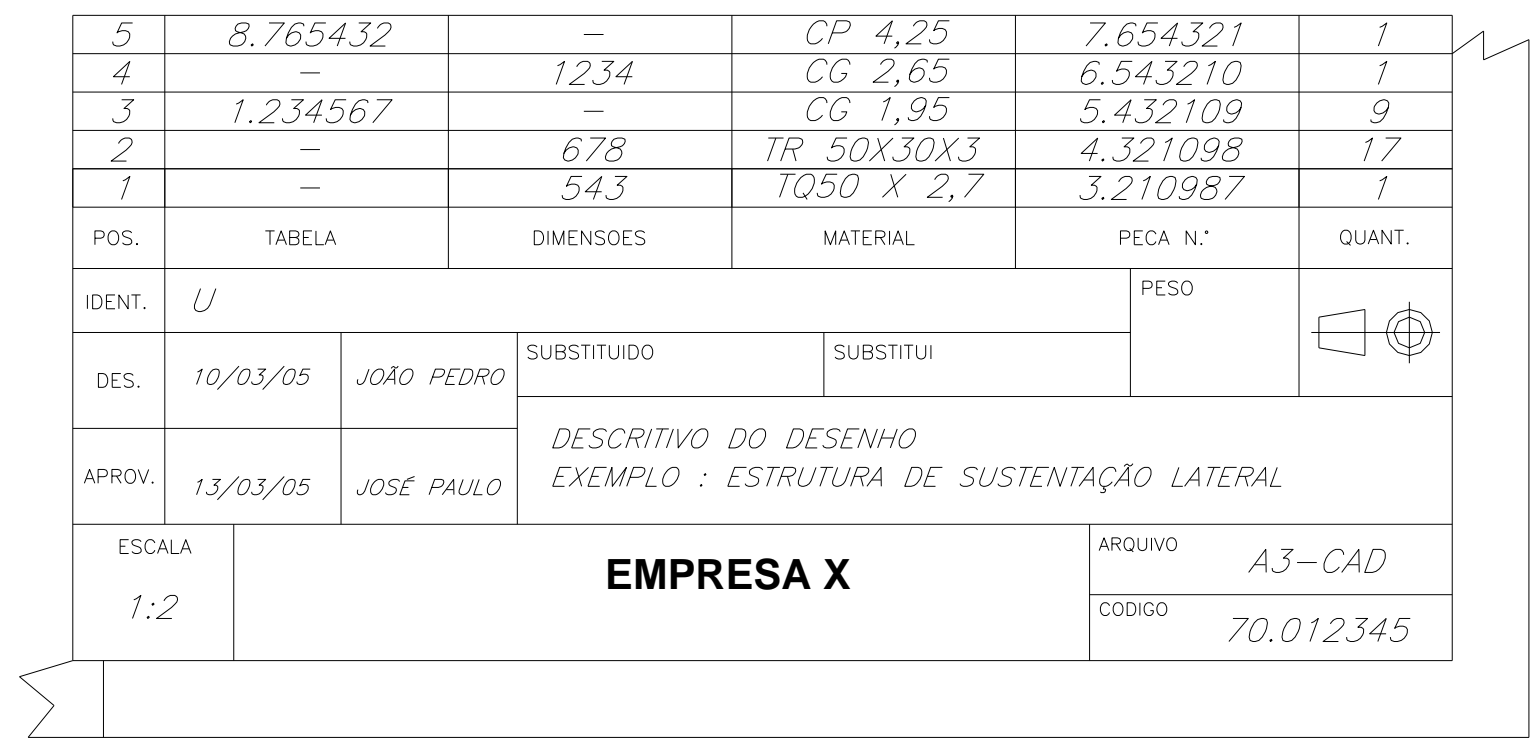

Toda folha de desenho deve possuir no canto inferior direito um quadro destinado à legenda. Este quadro deve conter o título do projeto/desenho, nome da empresa, escalas, unidades em que são expressas as informações, número da folha (caso o projeto tenha mais de uma folha), e outras informações necessárias para sua interpretação.

Figura - Exemplo de legenda.

\begin{tabular}{|l|l|c|c|c|}
\hline Título: & Data: & $\begin{array}{c}\text { Disciplina/Turma: } \\
\text { 2NA }\end{array}$ & Escala: & Unidade: \\
\hline Aluno(a): & $\begin{array}{c}\text { Disciplina/Turma: } \\
\text { 201X_MA }\end{array}$ & UFPR & $\mathbf{1} / \mathbf{1}$ \\
\hline
\end{tabular}

Acima da legenda é construído o quadro de especificações (ou NOTAS), contendo quantidade, denominação do objeto, material, acabamento superficial, entre outros que se julgar necessário.

A legenda deve ter $178 \mathrm{~mm}$ de comprimento nos formatos $\mathrm{A} 2$, A3 e A4, e 175 $\mathrm{mm}$ nos formatos $\mathrm{A} 0$ e $\mathrm{A} 1$.

\subsection{DOBRAGEM DE FOLHAS}

Toda folha com formato acima do A4 possui uma forma recomendada de dobragem. Esta forma visa que o desenho seja armazenado em uma pasta, que 
possa ser consultada com facilidade sem necessidade de retirá-la da pasta, e que a legenda estaja visível com o desenho dobrado.

As ilustrações a seguir mostram a ordem das dobras. Primeiro dobra-se na horizontal (em "sanfona"), depois na vertical (para trás), terminando a dobra com a parte da legenda na frente. A dobra no canto superior esquerdo é para evitar de furar a folha na dobra traseira, possibilitando desdobrar o desenho sem retirar do arquivo.

Figura - Dobragem de alguns formatos.
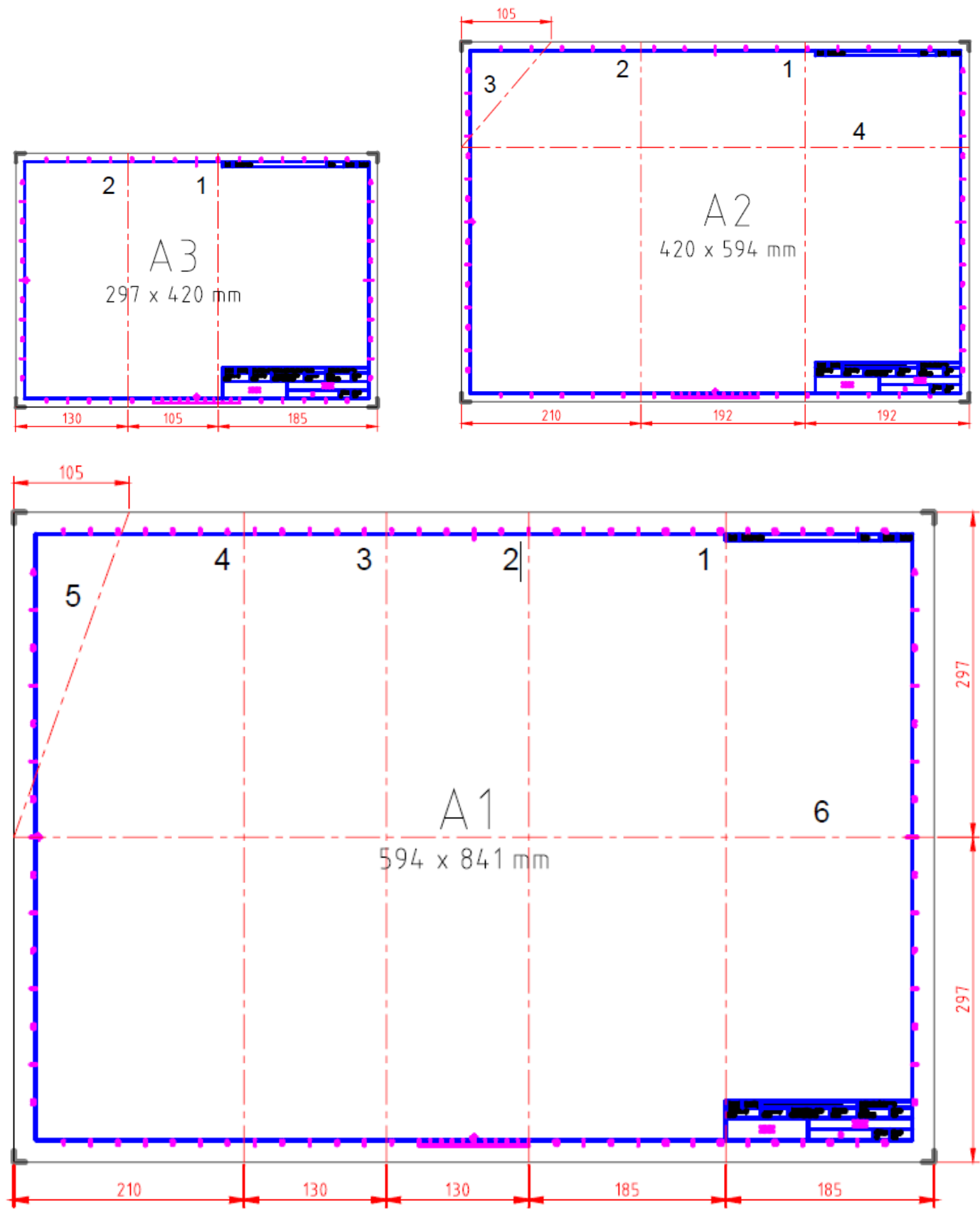

Catapan, Strobel e Santana (2020) 


\subsection{LETRAS E ALGARISMOS}

A NBR 8402 (ABNT, 1994) normaliza as condições para a escrita usada em Desenhos Técnicos e documentos semelhantes.

Visa à uniformidade, a legibilidade e a adequação à microfilmagem e a outros processos de reprodução.

"A habilidade no traçado das letras só é obtida pela prática contínua e com perseverança. Não é, pois, uma questão de talento artístico ou mesmo de destreza manual". (SILVA, 1987)

A maneira de segurar o lápis ou lapiseira é o primeiro requisito para o traçado das letras. A pressão deve ser firme, mas não deve criar sulcos no papel. Segundo Silva (1987) a distância da ponta do lápis até os dedos deve ser $1 / 3$ do comprimento do lápis, aproximadamente.

$\mathrm{Na}$ execução das letras e algarismos podem ser usadas pautas traçadas levemente, com lápis $\mathrm{H}$ bem apontado ou lapiseira $0,3 \mathrm{~mm}$ com grafite $\mathrm{H}$. Estas pautas são constituídas de quatro linhas conforme Figura 12. As distâncias entre estas linhas e entre as letras são apresentadas na Figura 13 e tabela 04 a seguir.

3.9 CALIGRAFIA TÉCNICA: EXEMPLO DE PAUTAS PARA ESCRITA EM DESENHO TÉCNICO

Figura: características da forma de escrita.

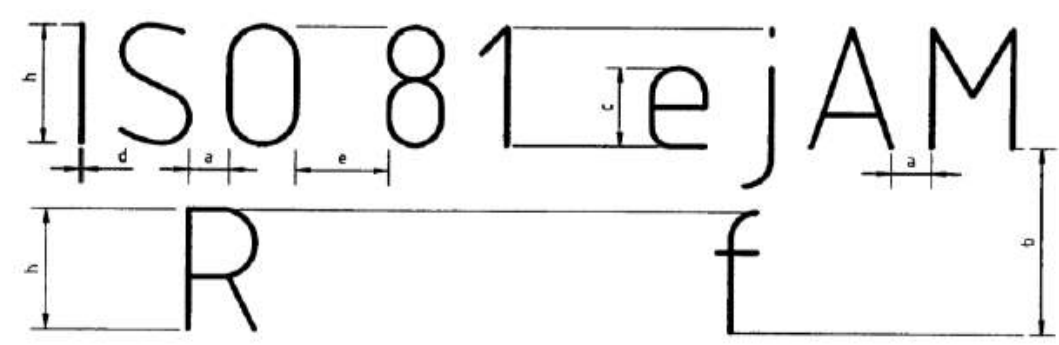

Fonte: NBR 8402 (ABNT, 1994)

Tabela - Proporções e dimensões de símbolos gráficos NBR 8402 (ABNT, 1994).

\begin{tabular}{|l|c|c|c|c|c|c|c|c|}
\hline \multicolumn{1}{|c|}{ Características } & Relação & \multicolumn{6}{|c|}{ Dimensões (mm) } \\
\hline Altura das Letras Maiúsculas - h & $(10 / 10) h$ & 2,5 & 3,5 & 5 & 7 & 10 & 14 & 20 \\
\hline Altura das Letras Minúsculas - c & $(7 / 10) h$ & - & 2,5 & 3,5 & 5 & 7 & 10 & 14 \\
\hline
\end{tabular}




\begin{tabular}{|l|c|c|c|c|c|c|c|c|}
\hline Distância Mínima entre Caracteres - a & $(2 / 10) \mathrm{h}$ & 0,5 & 0,7 & 1 & 1,4 & 2 & 2,8 & 4 \\
\hline Distância Mínima entre Linhas de Base - b & $(14 / 10) \mathrm{h}$ & 3,5 & 5 & 7 & 10 & 14 & 20 & 28 \\
\hline Distância Mínima entre Palavras - e & $(6 / 10) \mathrm{h}$ & 1,5 & 2,1 & 3 & 4,2 & 6 & 8,4 & 12 \\
\hline Largura da Linha - d & $(1 / 10) \mathrm{h}$ & 0,25 & 0,35 & 0,5 & 0,7 & 1 & 1,4 & 2 \\
\hline
\end{tabular}

A escrita pode ser vertical ou inclinada, em um ângulo de $15^{\circ}$ para a direita em relação à vertical.

Figura 1 - Forma da escrita vertical.

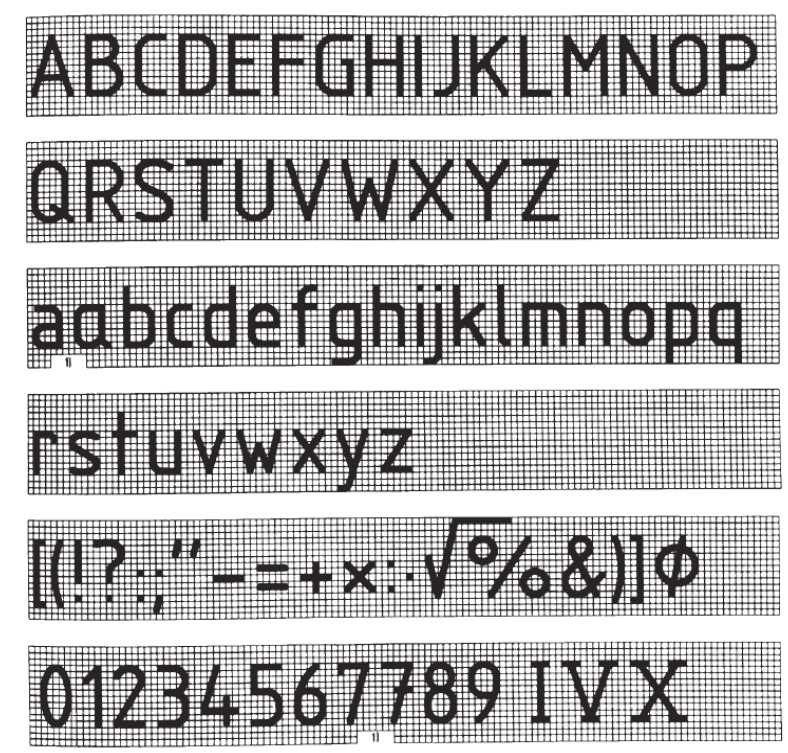

Fonte: NBR 8402 (ABNT, 1994)

Figura 2 - Forma da escrita inclinada.

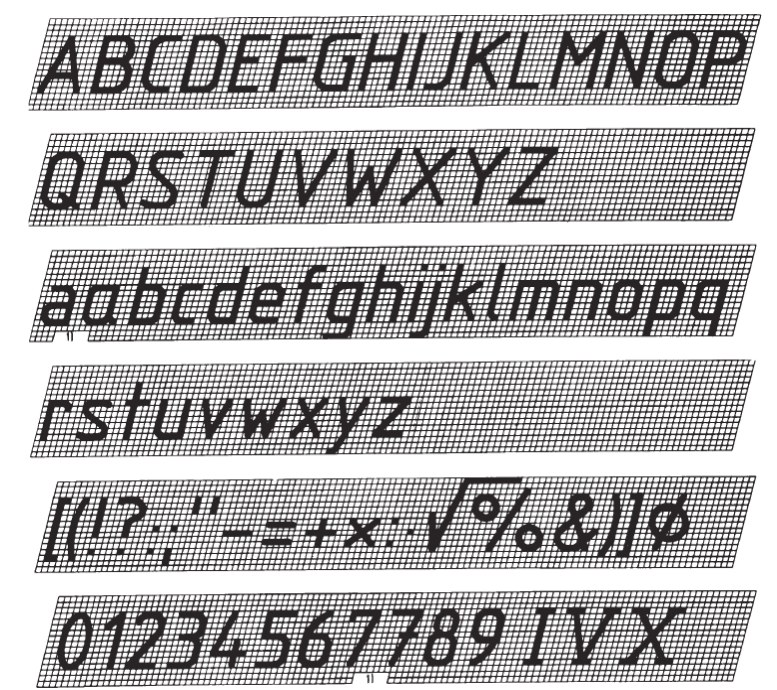

Fonte: NBR 8402 (ABNT, 1994) 


\subsection{TIPOS DE LINHAS E SUAS APLICAÇÕES}

A NBR 8403 (ABNT, 1984) fixa tipos e o escalonamento de larguras de linhas para uso em desenhos técnicos e documentos semelhantes (Tabela 05 e Figura 16).

A relação entre as larguras de linhas largas e estreita não deve ser inferior a 2. As larguras devem ser escolhidas, conforme o tipo, dimensão, escala e densidade de linhas do desenho, de acordo com o seguinte escalonamento: 0,$13 ; 0,18 ; 0,25$; 0,$35 ; 0,50 ; 0,70 ; 1,00 ; 1,40$ e 2,00mm. As larguras de traço 0,13 e $0,18 \mathrm{~mm}$ são utilizadas para originais em que a sua reprodução se faz em escala natural.

Figura - Demonstração de alguns tipos de linhas.
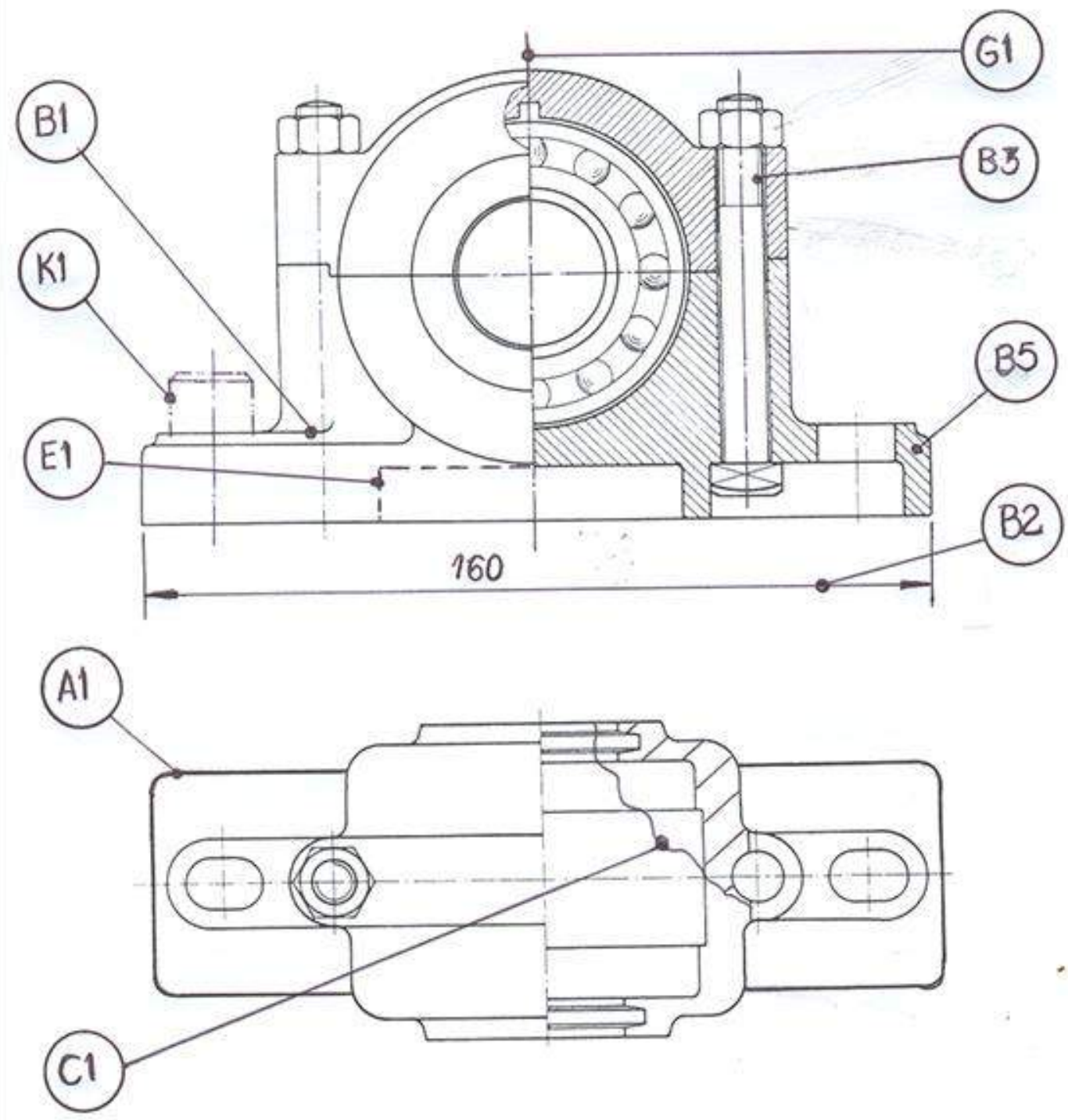
Figura - Demonstração de alguns tipos de linhas.

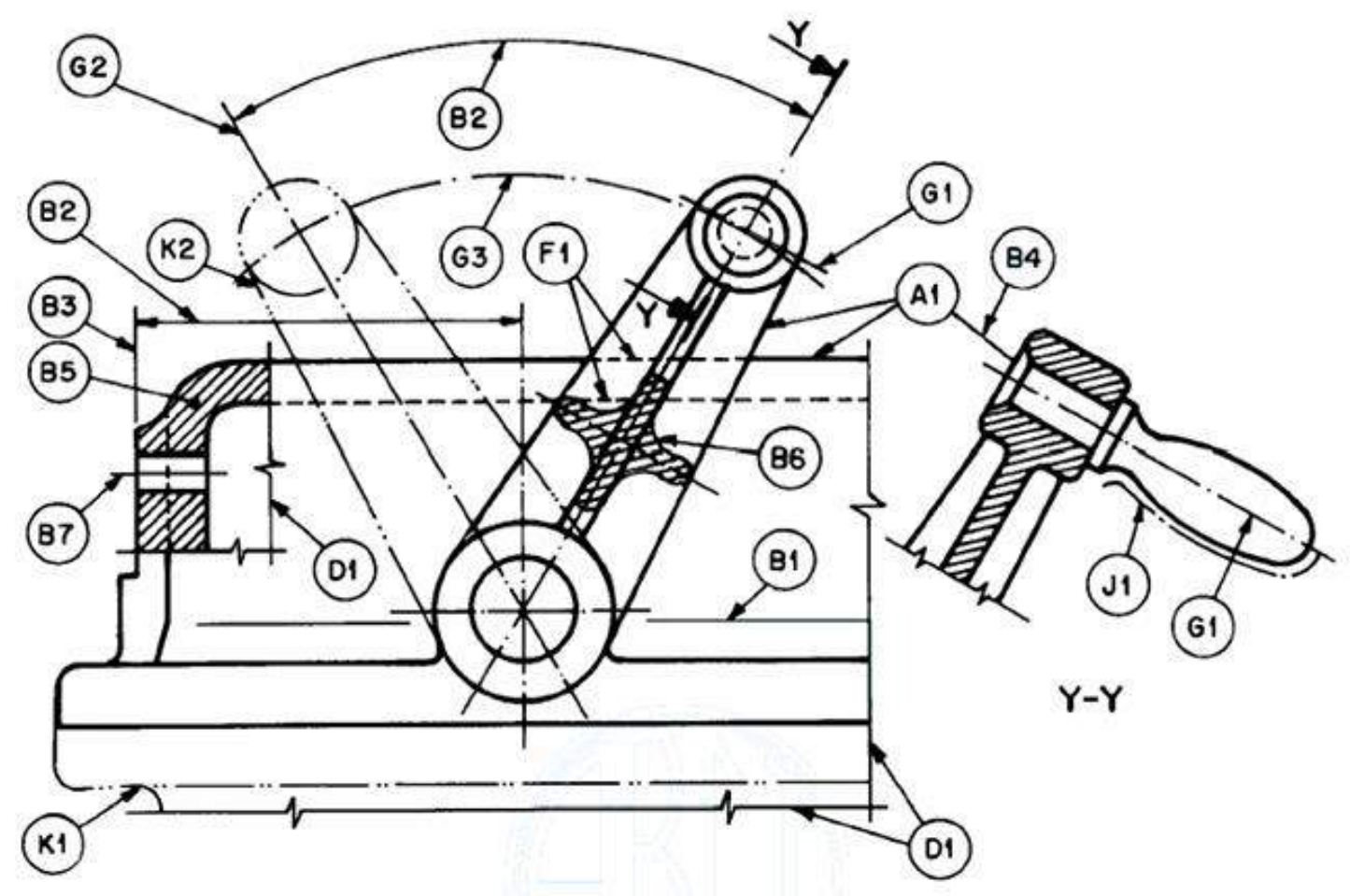

Fonte: NBR 8403 (ABNT, 1984) 


\begin{tabular}{|c|c|c|}
\hline LINHA & DENOMINAÇÃO & APLICAÇÃO GERAL \\
\hline A & Contínua larga & $\begin{array}{l}\text { A1 Contornos Visíveis } \\
\text { A2 Arestas Visíveis }\end{array}$ \\
\hline B & Contínua estreita & $\begin{array}{l}\text { B1 Linhas de interseção imaginárias } \\
\text { B2 Linhas de cotas } \\
\text { B3 Linhas auxiliares } \\
\text { B4 Linhas de chamada } \\
\text { B5 Hachuras } \\
\text { B6 Contornos de seções rebatidas na } \\
\text { própria vista } \\
\text { B7 Linhas de centro curtas }\end{array}$ \\
\hline c & $\begin{array}{l}\text { Contínua estreita a mão } \\
\text { livre (1) }\end{array}$ & $\begin{array}{l}\text { C1 Limites de vistas ou cortes parciais } \\
\text { ou interrompidas se os limites não } \\
\text { coincidir com linhas traço ponto }\end{array}$ \\
\hline${ }^{D} \sqrt{ }$ & $\begin{array}{l}\text { Contínua estreita em } \\
\text { zigue-zague (1) }\end{array}$ & $\begin{array}{l}\text { D1 Esta linha destina-se a desenho } \\
\text { confeccionados por máquinas }\end{array}$ \\
\hline $\begin{array}{l}E \\
-----\end{array}$ & Tracejada larga (1) & $\begin{array}{l}\text { E1 Contornos não visíveis } \\
\text { E2 Arestas não visíveis }\end{array}$ \\
\hline F ----- & Tracejada estreita (1) & $\begin{array}{l}\text { F1 Contornos não visíveis } \\
\text { F2 Arestas não visíveis }\end{array}$ \\
\hline G & Traço e ponto estreita (1) & $\begin{array}{l}\text { G1 Linhas de centro } \\
\text { G2 Linhas de simetrias } \\
\text { G3 Trajetória }\end{array}$ \\
\hline$\Gamma_{-\perp}^{H-}$ & $\begin{array}{l}\text { Traço e ponto estreito, } \\
\text { larga nas extremidades e } \\
\text { na mudança de direção }\end{array}$ & H1 Planos de corte \\
\hline J & Traço e ponto larga & $\begin{array}{l}\text { J1 Indicação das linhas ou superfícies } \\
\text { com } \\
\text { indicação especial }\end{array}$ \\
\hline K & $\begin{array}{l}\text { Traço e dois pontos } \\
\text { estreita }\end{array}$ & $\begin{array}{l}\text { K1 Contornos de peças adjacentes } \\
\text { K2 Posição limite de peças móveis } \\
\text { K3 Linhas de centro de gravidade } \\
\text { K4 Cantos antes de formação } \\
\text { K5 Detalhes situados antes do plano do } \\
\text { corte }\end{array}$ \\
\hline
\end{tabular}


Em muitas situações, ocorrem cruzamentos de linhas visíveis com invisíveis ou com linhas de eixo. Nestas situações, a representação pode ser tornada clara utilizando-se algumas convenções que, embora não normalizadas, podem ser bastante úteis, em particular para a realização e compreensão de esboços. Algumas destas convenções estão normalizadas pela ISO 128-20:1996, mas os programas de CAD normalmente não as utilizam. As convenções para a interseção de linhas são apresentadas na Tabela abaixo (SILVA et al, 2006).

Tabela - Interseção de linhas.

\begin{tabular}{|c|c|c|}
\hline Descrição & Correto & Incorreto \\
\hline $\begin{array}{l}\text { Quando uma aresta invisível termina } \\
\text { perpen-dicularmente ou } \\
\text { angularmente em relação a uma } \\
\text { aresta visível, toca a aresta visível. }\end{array}$ & --- & ----- \\
\hline $\begin{array}{l}\text { Se existir uma aresta visível no } \\
\text { prolonga-mento de uma aresta } \\
\text { invisível, então a aresta invisível não } \\
\text { toca a aresta visível. }\end{array}$ & -- & $\begin{array}{l}----\dashv- \\
----\dashv- \\
----\end{array}$ \\
\hline $\begin{array}{l}\text { Quando duas ou mais arestas } \\
\text { invisíveis terminam num ponto, } \\
\text { devem tocar-se. }\end{array}$ & $\begin{array}{r}--------1 \\
-1\end{array}$ & $\underset{1}{1}-1$ \\
\hline $\begin{array}{l}\text { Quando uma aresta invisível cruza } \\
\text { outra aresta (visível ou invisível), } \\
\text { não deve tocá-la. }\end{array}$ & 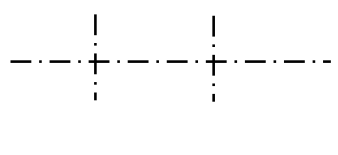 & \\
\hline $\begin{array}{l}\text { Quando duas linhas de eixo se } \\
\text { interceptam, devem tocar-se. }\end{array}$ & 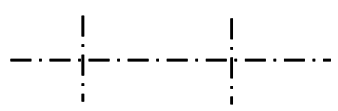 & \\
\hline
\end{tabular}

Fonte: Silva et al, 2006. 
EXEMPLOS
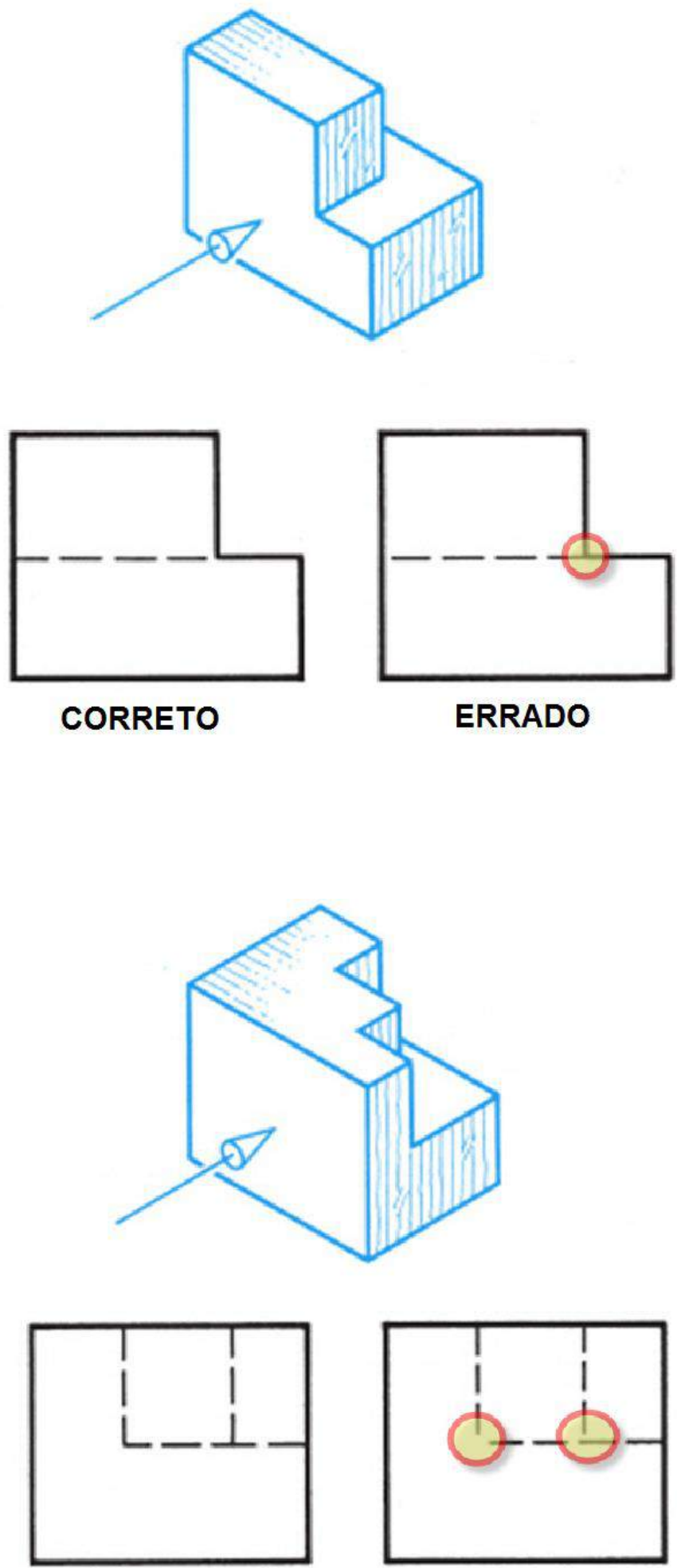

Catapan, Strobel e Santana (2020) 


\section{CAPÍTULO 4}

ESCALAS

Deve-se sempre que possível, procurar fazer o desenho nas medidas reais da peça, para transmitir uma idéia melhor de sua grandeza. Para componentes que são demasiadamente pequenos, precisamos fazer ampliações que permitam a representação de todos os detalhes conforme norma. No caso inverso, isto é, para peças de grande tamanho, o desenho deve ter proporções menores, sendo possível assim a sua execução dentro dos formatos padronizados.

A Norma NBR 8196 OUT / 1983, define que a designação completa de uma escala deve consistir da palavra "ESCALA", seguida da indicação da relação como segue:

\begin{tabular}{|c|c|c|}
\hline$\overline{R e d u c ̧ a ̃ o ~}$ & Natural & Ampliação \\
\hline 1:2 & $1: 1$ & $2: 1$ \\
\hline $1: 5$ & & $\begin{array}{r}5: 1 \\
10: 1\end{array}$ \\
\hline $\begin{array}{l}1: 10 \\
1 \cdot 20\end{array}$ & & $\begin{array}{l}10: 1 \\
20: 1\end{array}$ \\
\hline $\begin{array}{l}1: 20 \\
1: 100\end{array}$ & & $100: 1$ \\
\hline $1: 200$ & & $200:$ \\
\hline 1:500 & & 500: \\
\hline 1:1000 & & 1000 \\
\hline
\end{tabular}

Escala é uma relação que se estabelece entre as dimensões de um objeto em verdadeira grandeza e aquelas que ele possui em um desenho. 


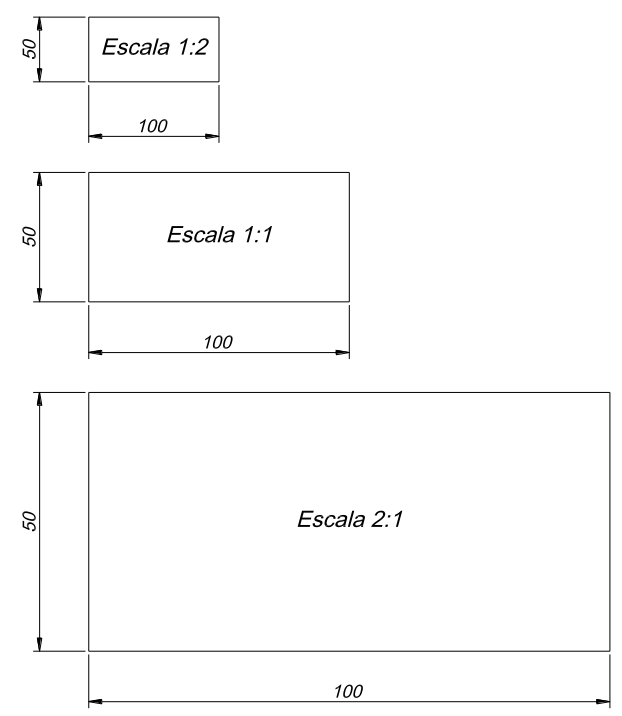

Observações: independente do uso de escalas reduzidas ou ampliadas, a cotagem sempre é feita com as medidas reais da peça. A escala utilizada sempre deve ser escrita na legenda. A escala a ser escolhida para um desenho depende da complexidade do objeto a ser representado e da finalidade da representação. Em todos os casos, a escala selecionada deve ser suficientemente grande para permitir uma interpretação fácil e clara da informação representada. A escala e o tamanho do objeto em questão deverão decidir o formato da folha.

Figura - Exemplos de peças em escala.
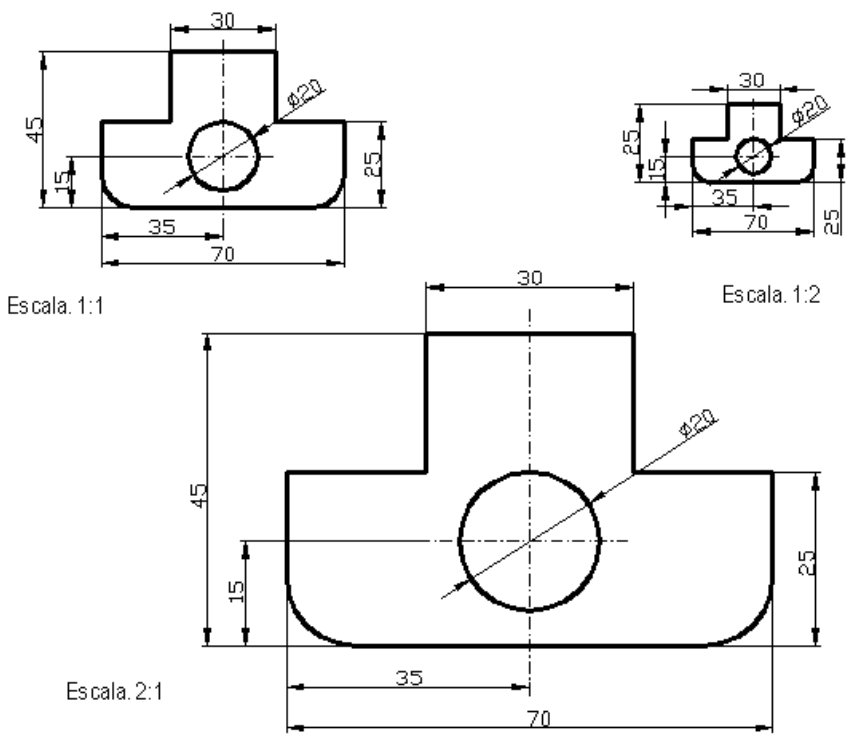
A designação completa de uma escala deve consistir na palavra "ESCALA", seguida da indicação da relação: a) ESCALA 1:1, para escala natural; b) ESCALA $X: 1$, para escala de ampliação $(X>1)$; c) ESCALA 1:X, para escala de redução $(X>$ 1).

\subsection{INSTRUMENTOS DE DESENHO}

Pranchetas (mesas para desenho) - construídas com tampo de madeira macia e revestidas com plástico apropriado, comumente verde, por produzir excelente efeito para o descanso dos olhos.

Régua paralela - instrumento adaptável à prancheta, funcionando através de um sistema de roldanas.

Tecnígrafo - instrumento adaptável à prancheta reunindo, num só mecanismo, esquadro, transferidor, régua paralela e escala.

Régua "T" - utilizada sobre a prancheta para traçado de linhas horizontais ou em ângulo, servindo ainda como base para manuseio dos esquadros.

Esquadros - utilizados para traçar linhas, normalmente fornecidos em pares (um de $30^{\circ} / 60^{\circ}$ e um de $45^{\circ}$ ).

Transferidor - instrumento destinado a medir ângulos. Normalmente são fabricados modelos de $180^{\circ}$ e $360^{\circ}$.

Escalímetro - utilizada unicamente para medir, não para traçar.

Compasso - utilizado para o traçado de circunferências, possuindo vários modelos (cada qual com a sua função), alguns possuindo acessórios como tiralinhas e alongador para círculos maiores.

Curva francesa - gabarito destinado ao traçado de curvas irregulares.

Gabaritos - fornecidos em diversos tamanhos e modelos para as mais diversas formas (círculos, elipses, específicos para desenhos de engenharia civil, elétrica, etc.)

Lápis ou lapiseira - atualmente as mais utilizadas são as lapiseiras com grafite de $0,5 \mathrm{~mm}$ e $0,7 \mathrm{~mm}$ de diâmetro.

Observações: Para a disciplina de Desenho Técnico, são necessários os instrumentos destacados em negrito. Ou seja, Esquadros (um de 30\%/60 e um de 45ㅇ - sem escala e de acrílico transparente - recomenda-se tamanho de 200 $\mathrm{mm}$ ); Transferidor (simples); Escalímetro (régua boa); Compasso (muito bom - evitar os de plástico simples); Duas Lapiseiras $-1^{\underline{a}}$ com grafite $\mathbf{0 , 7}$ para 0 traçado dos 
contornos da peça e a $2^{-a}$ com grafite $\mathbf{0 , 5}$ para o traçado linhas auxiliares e de cotas; Borracha branca e macia.

4.2 MATERIAIS COMPLEMENTARES

Flanela, escova para limpeza, fita adesiva, borrachas e grafites para a reposição.

\subsection{GRAU DE DUREZA DOS GRAFITES}

A graduação dos grafites está mostrada na Tabela 1.

Tabela 01 - Grau de dureza dos grafites.

\begin{tabular}{|c|c|c|c|c|}
\hline $9 \mathrm{H} \mathrm{a} \mathrm{4H}$ & $3 \mathrm{H}, 2 \mathrm{H} \mathrm{e} \mathrm{H}$ & F e HB & B e 2B & 3B, 4B, 5B e 6B \\
\hline $\begin{array}{c}\text { extremamente } \\
\text { duros }\end{array}$ & duros & médios & macios & $\begin{array}{c}\text { macios a } \\
\text { extremamente } \\
\text { macios }\end{array}$ \\
\hline
\end{tabular}




\section{CAPÍTULO 5}

\section{VISTAS ORTOGRÁFICAS}

Utilizando o sistema de projeções cilíndricas ortogonais, o matemático francês Gaspard Monge criou a Geometria Descritiva que serviu de base para o Desenho Técnico. Utilizando dois planos perpendiculares, um horizontal $(\pi$ ') e outro vertical $(\pi ")$, ele dividiu o espaço em quatro partes denominados diedros.

Um objeto colocado em qualquer diedro terá as suas projeções horizontal e vertical (Figura 5.1). Como o objetivo é visualizar o objeto num só plano, o desenho é denominado "épura", ou planificação do diedro, que consiste na rotação do plano horizontal, de modo que a parte anterior do $\pi$ ' coincida com a parte inferior de $\pi$ ", enquanto o plano vertical permanece imóvel (figura 5.2). A linha determinada pelo encontro dos dois planos é chamada de Linha de Terra (LT).

Figura 5.1 - Representação das projeções de um objeto no $1^{\circ}$ e $3^{\circ}$ diedros.

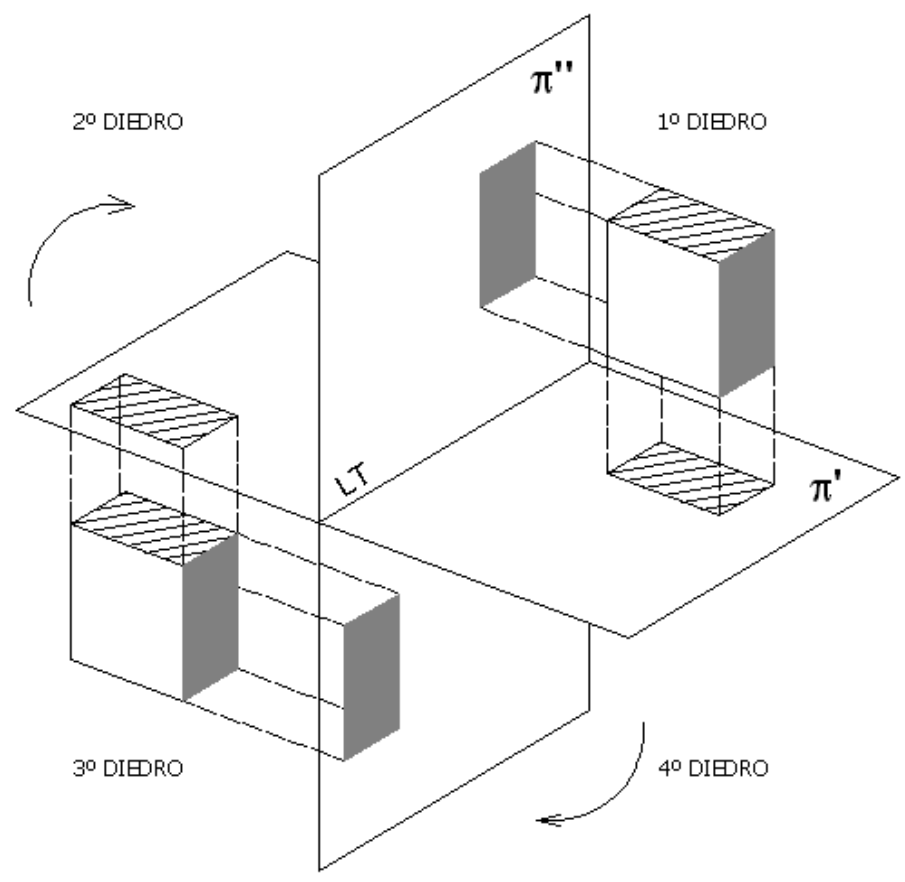


Figura 4.2 - Representação das épuras dos objetos da figura anterior.

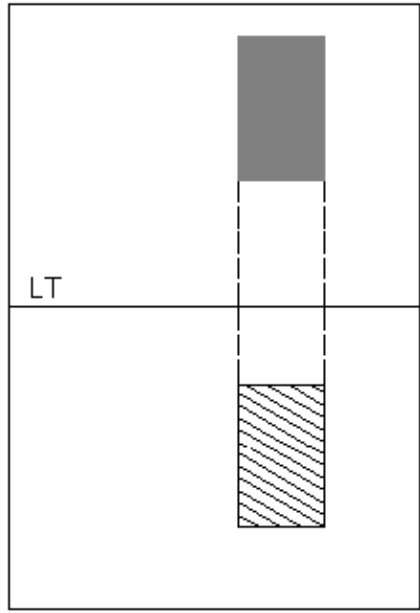

Projeção mo $1^{\circ}$ DIEDRO

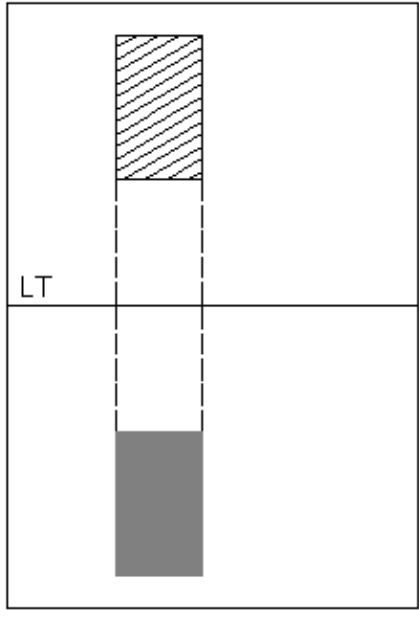

Projeção no $3^{\circ}$ DIEDRO

Pode-se citar algumas diferenças entre a Geometria Descritiva e o Desenho Técnico. Na Geometria Descritiva duas projeções são suficientes para representar um objeto, recorrendo raramente ao plano de perfil, isto se deve ao fato de utilizarmos letras na identificação dos vértices e arestas dos objetos representados. Já no Desenho Técnico, esta identificação torna-se impraticável, utilizando-se, normalmente, uma terceira projeção, para definir de modo inequívoco a forma dos objetos. A segunda distinção é encontrada no posicionamento do objeto. Em Desenho Técnico o objeto é colocado com suas faces principais paralelas aos planos de projeção, de modo a obtê-las em verdadeira grandeza (VG) na projeção em que seja paralela. O mesmo não ocorre com a Geometria Descritiva, onde se resolvem problemas de representação com objetos colocados em qualquer posição relativa aos planos de referência.

Define a Norma Técnica Brasileira NBR ISO 10209-2 (2005) que o termo "Representação ortográfica" significa "projeções ortogonais de um objeto posicionado normalmente com suas faces principais paralelas aos planos coordenados, sobre um ou mais planos de projeção, coincidentes ou paralelos aos planos coordenados. Estes planos de projeção são convenientemente rebatidos sobre a folha de desenho, de modo que as posições das vistas do objeto sejam relacionadas entre si“. As vistas de um objeto habitualmente são obtidas sobre três planos perpendiculares entre si, um vertical, um horizontal e outro de perfil, que definem um triedro tri-retângulo como sistema de referência. 


\section{CAPÍTULO 6}

\section{DIEDROS}

Atualmente, a maioria dos países que utilizam o método de representação por diedros adotam a projeção ortogonal no 1ำ diedro. No Brasil, a ABNT recomenda a representação no 1ำ diedro. Entretanto, alguns países, como por exemplo os Estados Unidos e o Canadá, representam seus desenhos técnicos no 3ํ diedro.

No 1ำ Diedro o objeto se situa entre o observador e o plano de projeção. No $3^{\circ}$ Diedro o plano de projeção se situa entre o objeto e o observador. Esses símbolos aparecem no canto inferior direito da folha de papel dos desenhos técnicos, dentro da Legenda. A seguir serão mostradas as diferenças de representações de desenhos em $1^{\circ}$ e $3^{\circ}$ diedro.

1ํㅡㄹ Diedro
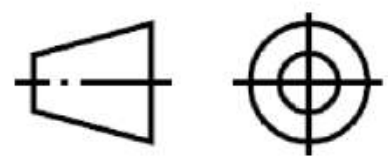

3ํDiedro
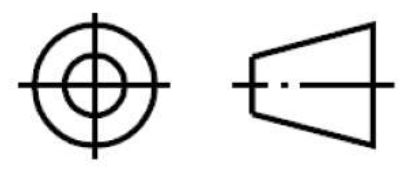

\subsection{REPRESENTAÇÃO NO 1 DIEDRO}

No $1^{\circ}$ diedro o objeto está entre o observador e o plano de projeção. $\mathrm{Na}$ Figura 6.1, podemos verificar três vistas ortográficas de um mesmo objeto que está disposto de modo a satisfazer a condição de paralelismo de duas faces com os três planos do triedro. Essas três vistas ortográficas habituais, que garantem a univocidade da representação do objeto, são denominadas: vista frontal (VF), vista superior (VS) e vista lateral esquerda (VLE). Planifica-se esta representação rebatendo o plano horizontal e o de perfil sobre o plano vertical.

O sistema de projeção no $1^{0}$ diedro é conhecido como Método Alemão ou Método Europeu. É adotado pela norma alemã DIN (Deutsches Institut für Normung) e também pela ABNT (Associação Brasileira de Normas Técnicas). 
Figura 6.1 - Projeção de um objeto no 1ํ diedro.
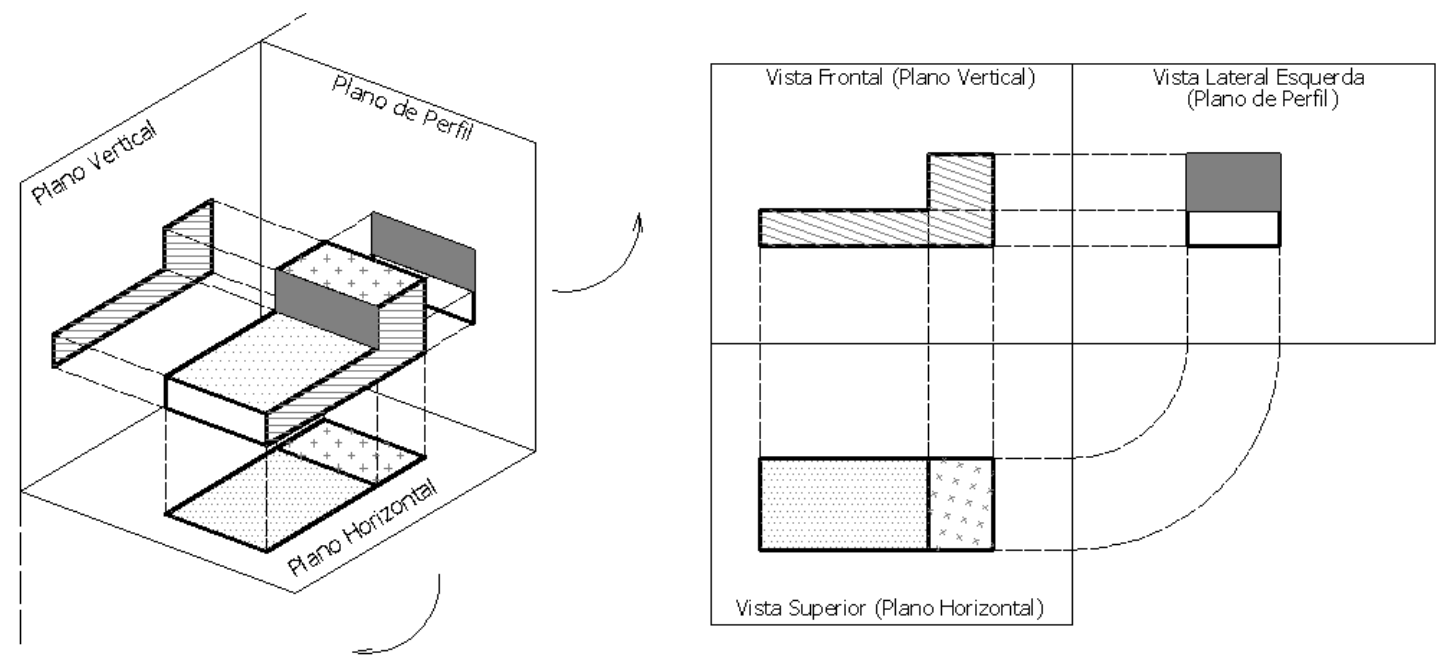

Em casos muito esporádicos (de peças complicadas), pode recorrer-se a mais planos de projeção, para representar mais vistas além das habituais (VF, VS VL), correspondendo a envolver a peça em um paralelepípedo de referência (triedro tri-retângulo fechado), que é posteriormente aberto e rebatido. Obtêm-se assim, seis vistas do objeto (Figura 6.2).

Figura 6.2 - Projeção no $1^{\circ}$ diedro.
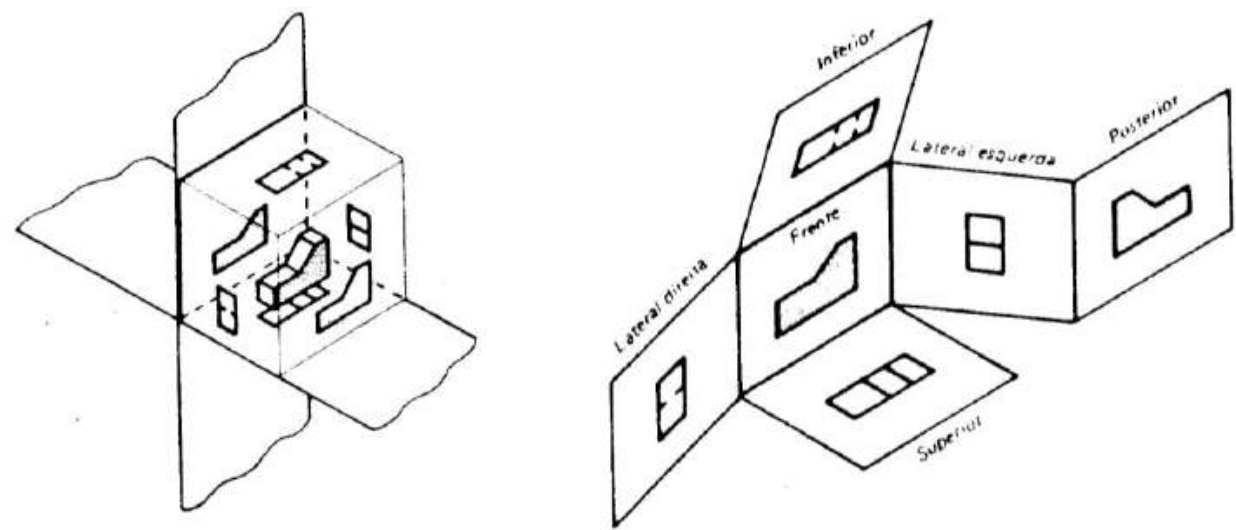
A projeção de um objeto no primeiro diedro corresponde à representação ortográfica compreendendo o arranjo, em torno da vista principal de um objeto, de algumas ou de todas as outras cinco vistas desse objeto. Com relação à vista principal (vista frontal), as demais vistas são organizadas da seguinte maneira: a vista superior (VS) fica abaixo, a vista inferior (VI) fica acima, a vista lateral esquerda (VLE) fica à direita, a vista lateral direita (VLD) fica à esquerda e a vista posterior (VP) fica à direita ou à esquerda, conforme conveniência (Figura 6.3).

Figura 6.3 - Exemplo das seis vistas ortográficas possíveis de uma peça, no 1ํ diedro.
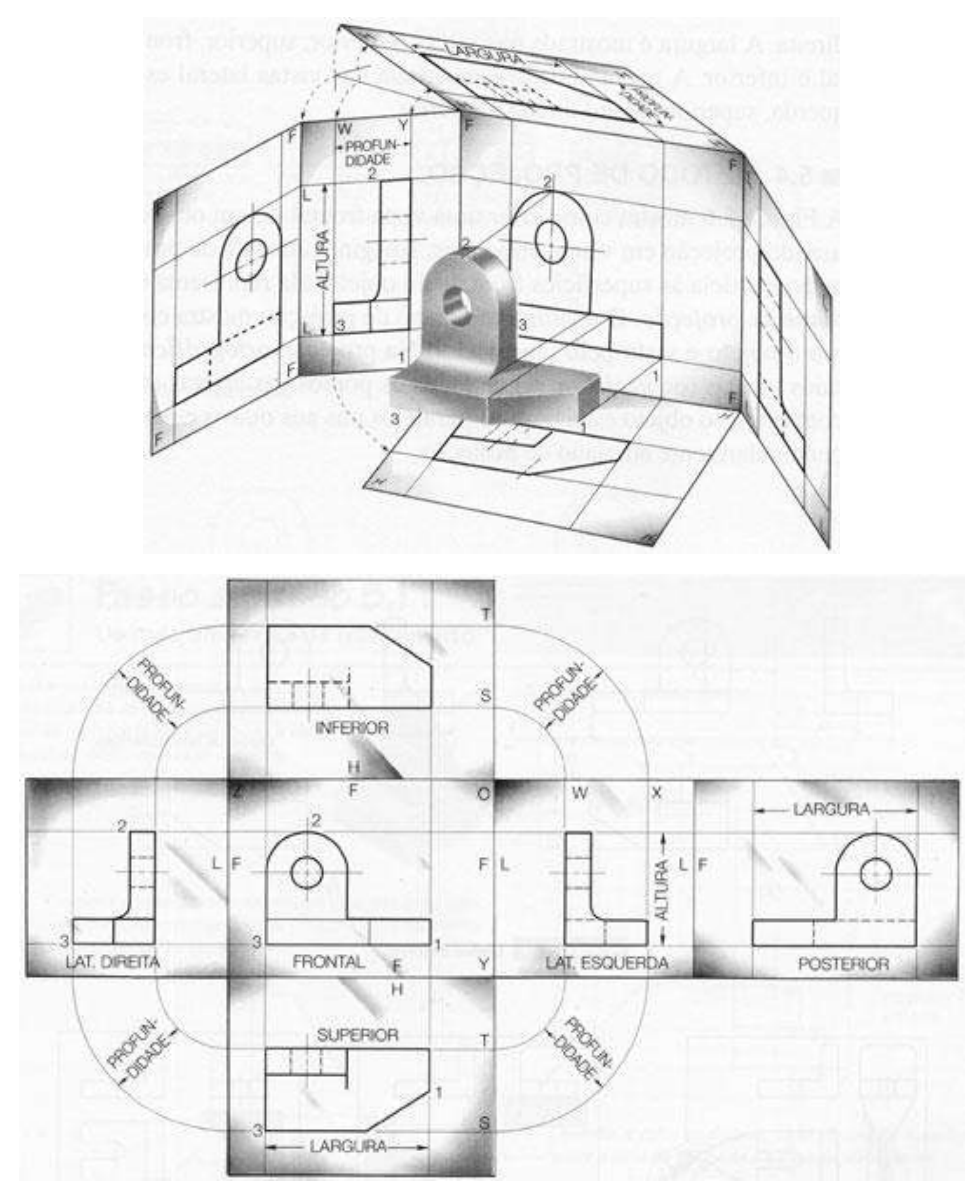

A projeção horizontal (VS ou VI) fornece a largura e a profundidade, a vertical (VF ou VP) fornece a largura e a altura, e a de perfil (VLD ou VLE) fornece a profundidade e a altura. 
Figura 6.4 - Forma de Projeção no 1ํDiedro das vistas principais.

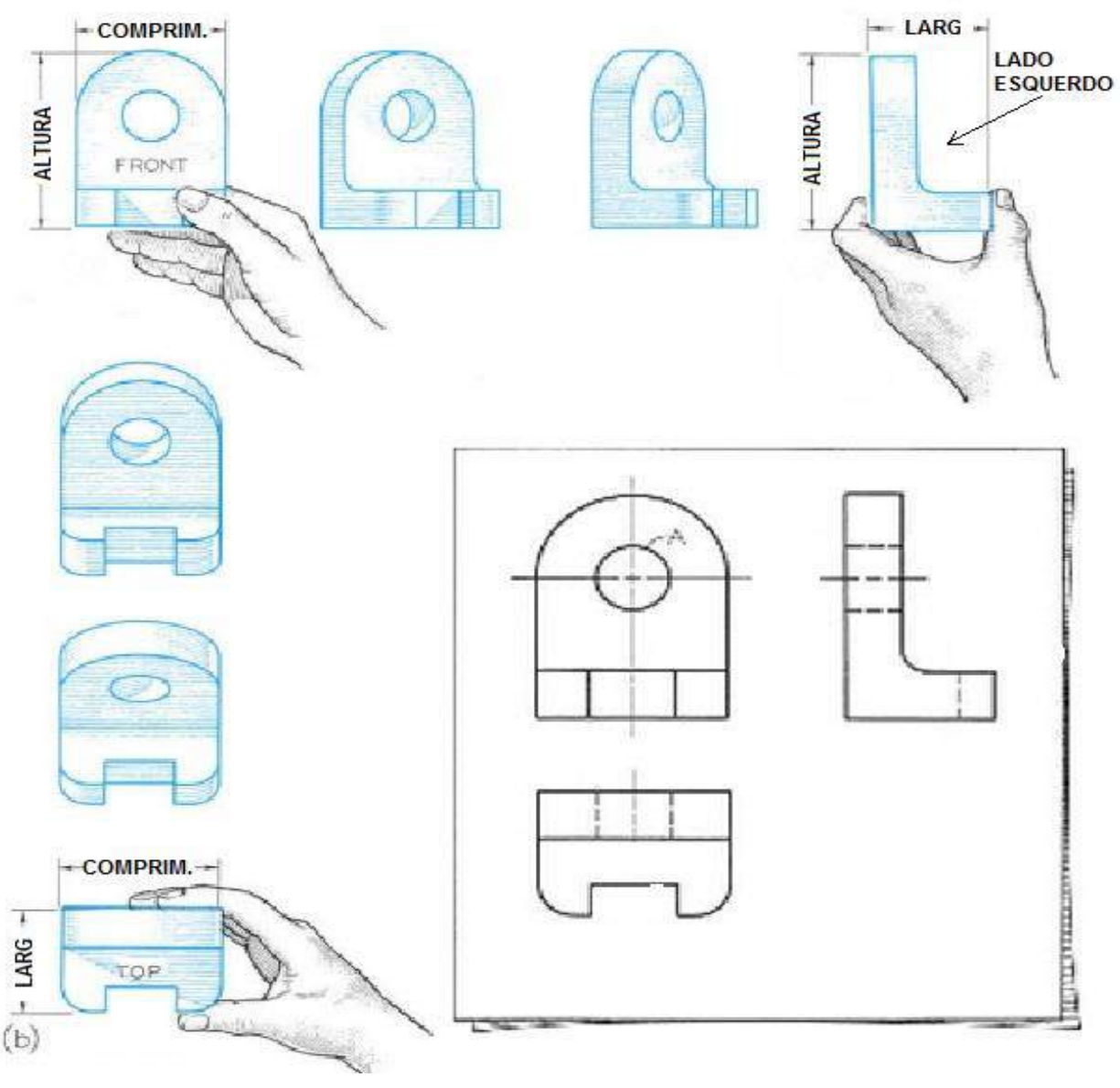

Figura 6.5 - Como definir as vistas em uma perspectiva isométrica.

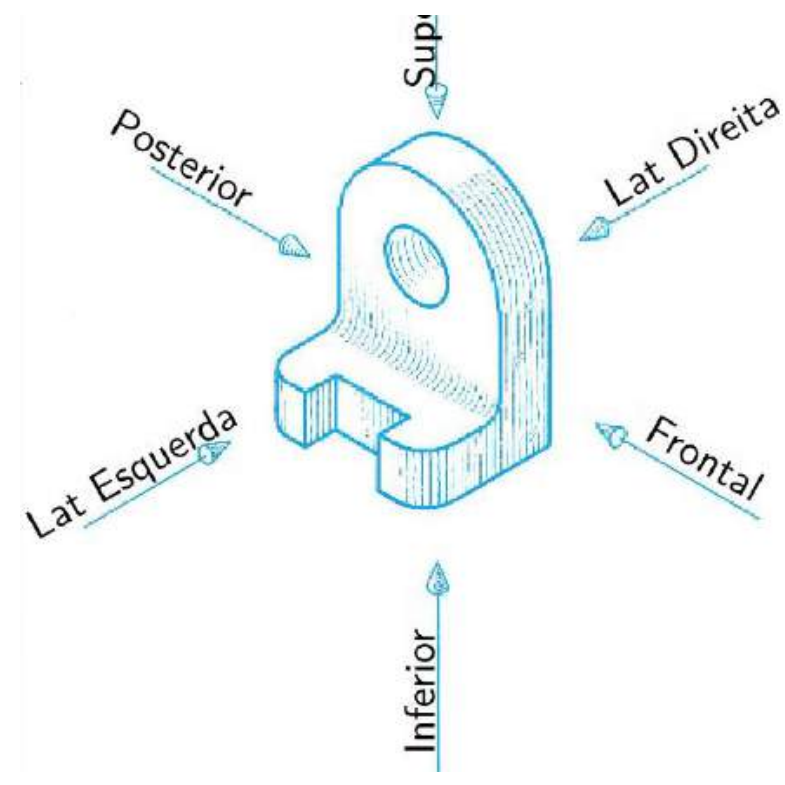

Catapan, Strobel e Santana (2020) 
Figura 6.6 - Como projetar as vistas através de uma perspectiva isométrica.

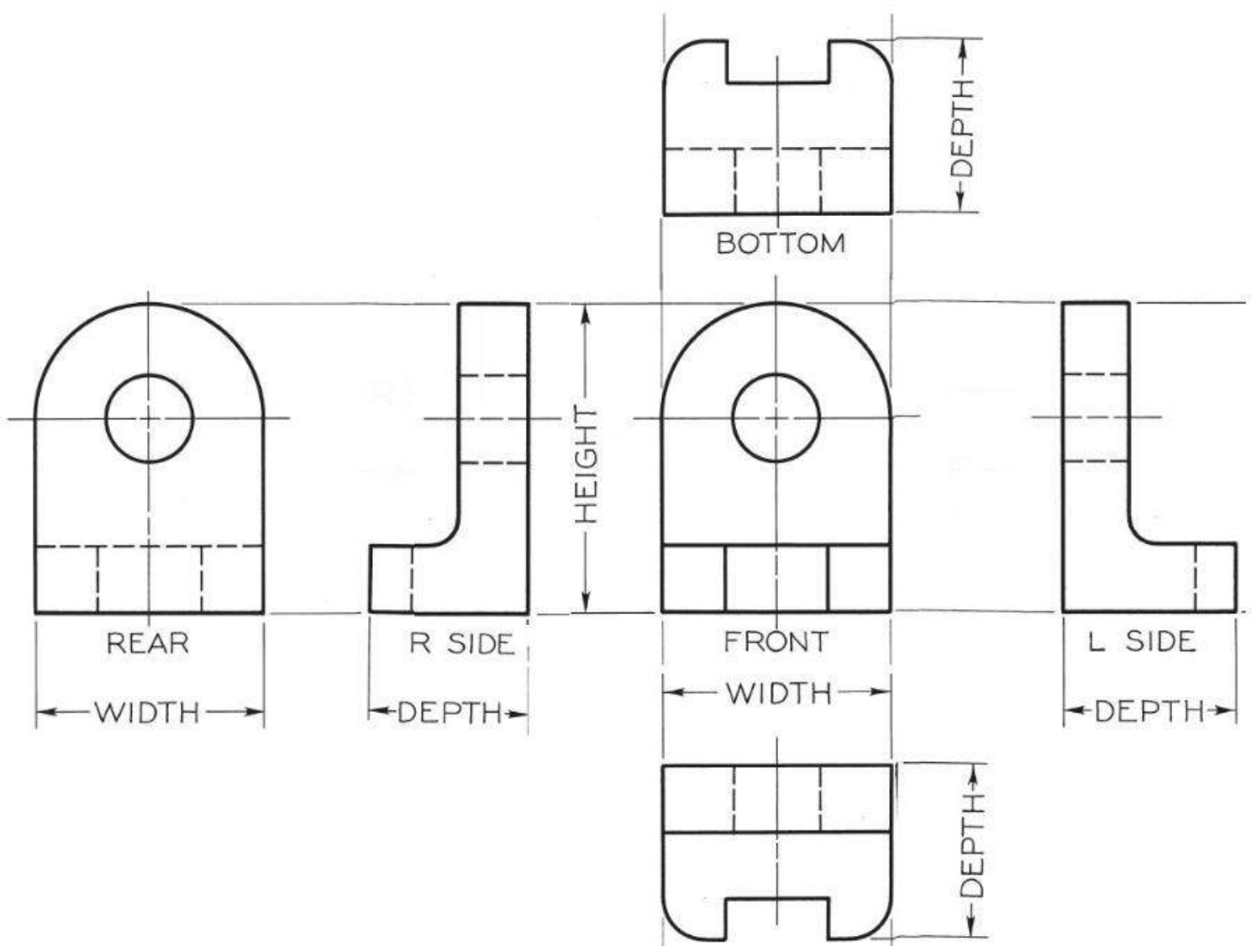

Quando a vista oposta a uma habitual for idêntica a esta ou totalmente desprovida de detalhes, não é necessária a sua representação, bastando a vista habitual. No caso de sólidos assimétricos é necessário apresentar as vistas opostas às habituais ou recorrer a outro tipo de representação convencional, como cortes, seções ou vistas auxiliares.

Se o objeto possuir faces inclinadas em relação aos planos do paralelepípedo de referência e é necessário representar a verdadeira grandeza dessas faces, deverão ser utilizados planos de projeção auxiliares, paralelos àquelas faces e rebatidos sobre os planos habituais de referência.

\subsection{REPRESENTAÇÃO NO 3 DIEDRO}

No 3ำ diedro o plano de projeção está situado entre o observador e o objeto. O sistema de projeção no $3^{\circ}$ diedro (Figura 6.7) é conhecido como Método Americano e é adotado pela norma americana ANSI (American National Standards Institute). 
Figura 6.7 - Projeção de um objeto no $3^{\circ}$ diedro.
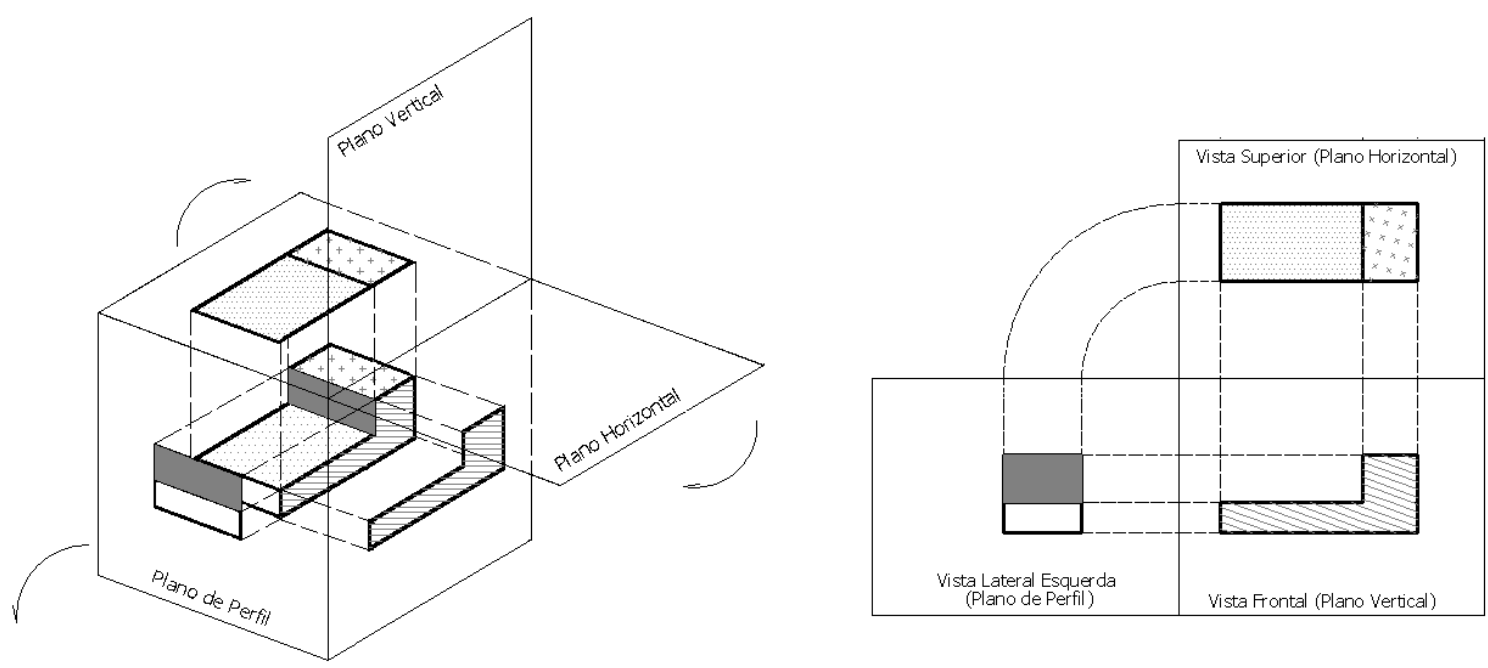

Com relação à vista principal, a vista frontal, as demais vistas são organizadas da seguinte maneira: a vista superior fica acima, a vista inferior fica abaixo, a vista lateral esquerda fica à esquerda, a vista lateral direita fica à direita e a vista posterior fica à direita ou à esquerda, conforme conveniência (Figura 6.8).

Figura 6.8 - Projeção no 3ํ diedro.
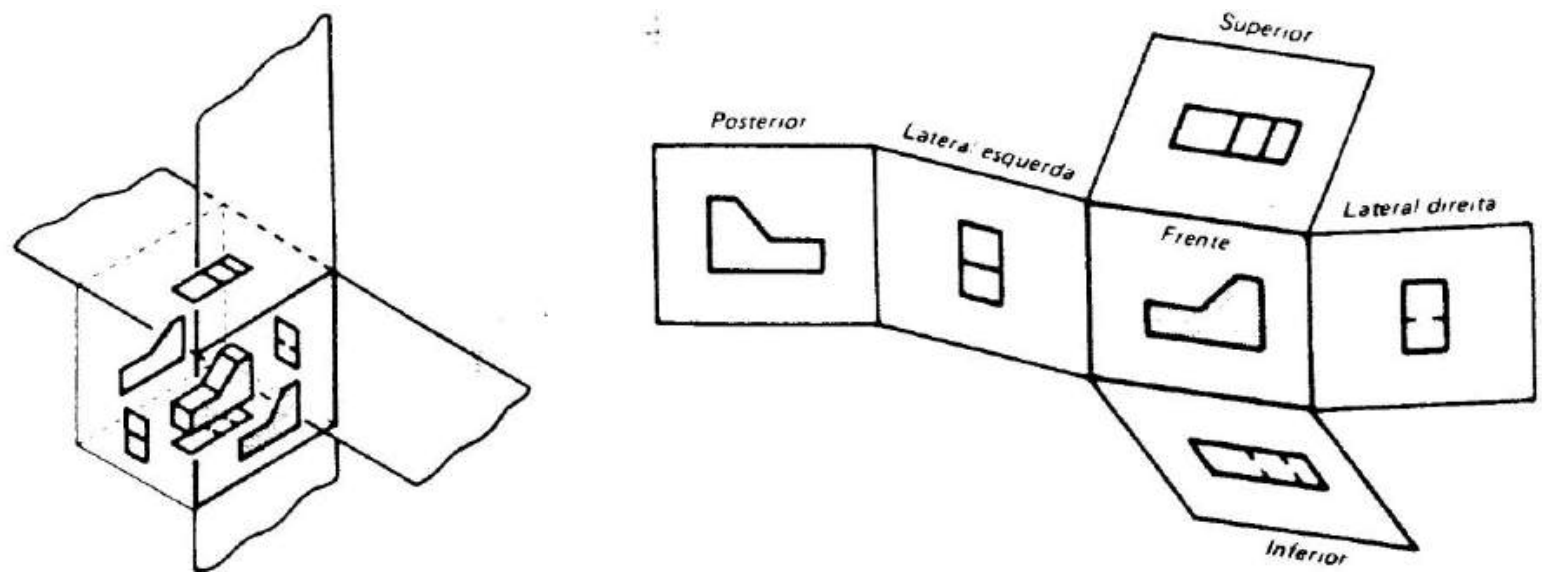

A diferença fundamental entre os dois métodos está na posição das vistas (Figura 6.9), sendo a vista frontal a principal. A vista de frente também é chamada de elevação e a superior de planta. 
Figura 6.9 - Exemplo das vistas ortográficas no sistema europeu e no sistema americano.

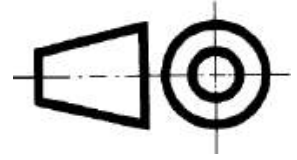

PRIMEIRO DIEDRO - MÉTODO EUROPEU

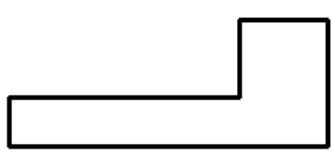

Vista Frontal

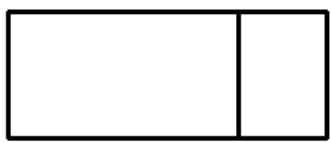

Vista Superior

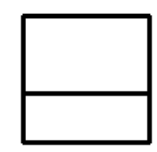

Vista Lateral Esquerda

TERCEIRO DIEDRO - MÉTODO AMERICANO

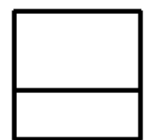

Vista Lateral Esquerda

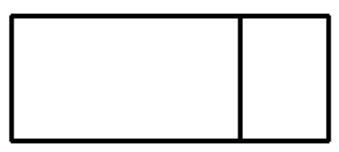

Vista Superior
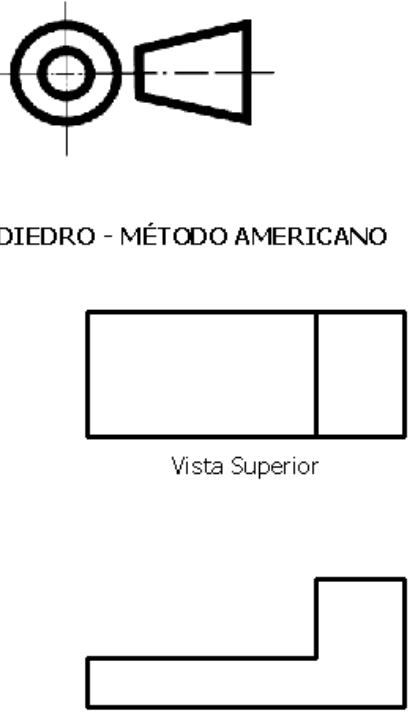

Vista Fronta

\subsection{OBTENÇÃO DAS VISTAS ORTOGRÁFICAS}

O objeto é colocado no interior do triedro tri-retângulo para obter suas vistas. A vista de frente deve ser a principal. Esta vista comanda a posição das demais. É conveniente que se faça uma análise do objeto, com o objetivo de escolher a melhor posição para a vista de frente.

A escolha da vista de frente deve ser:

a) Aquela que mostre a forma mais característica do objeto;

b) A que indique a posição de trabalho do objeto, ou seja, como ele é encontrado, isoladamente ou num conjunto;

c) Se os critérios anteriores forem insuficientes, escolhe-se a posição que mostre a maior dimensão do objeto e possibilite o menor número de linhas invisíveis nas outras vistas.

Em Desenho Técnico não se representam nem a linha de terra nem o traço do plano de perfil. Porém, devem ser obedecidas as regras de posicionamento relativo das vistas, decorrentes da teoria de dupla projeção ortogonal e do rebatimento dos planos de referência.

Para obter as vistas de um objeto, inicialmente, são comparadas as dimensões de largura, altura e profundidade, para a escolha da posição vertical ou 
horizontal do papel. Efetua-se então a representação das vistas necessárias do objeto, de acordo com suas dimensões (Figura 6.10).

Figura 6.10 - Vistas ortográficas de um objeto no $1^{\circ}$ diedro.
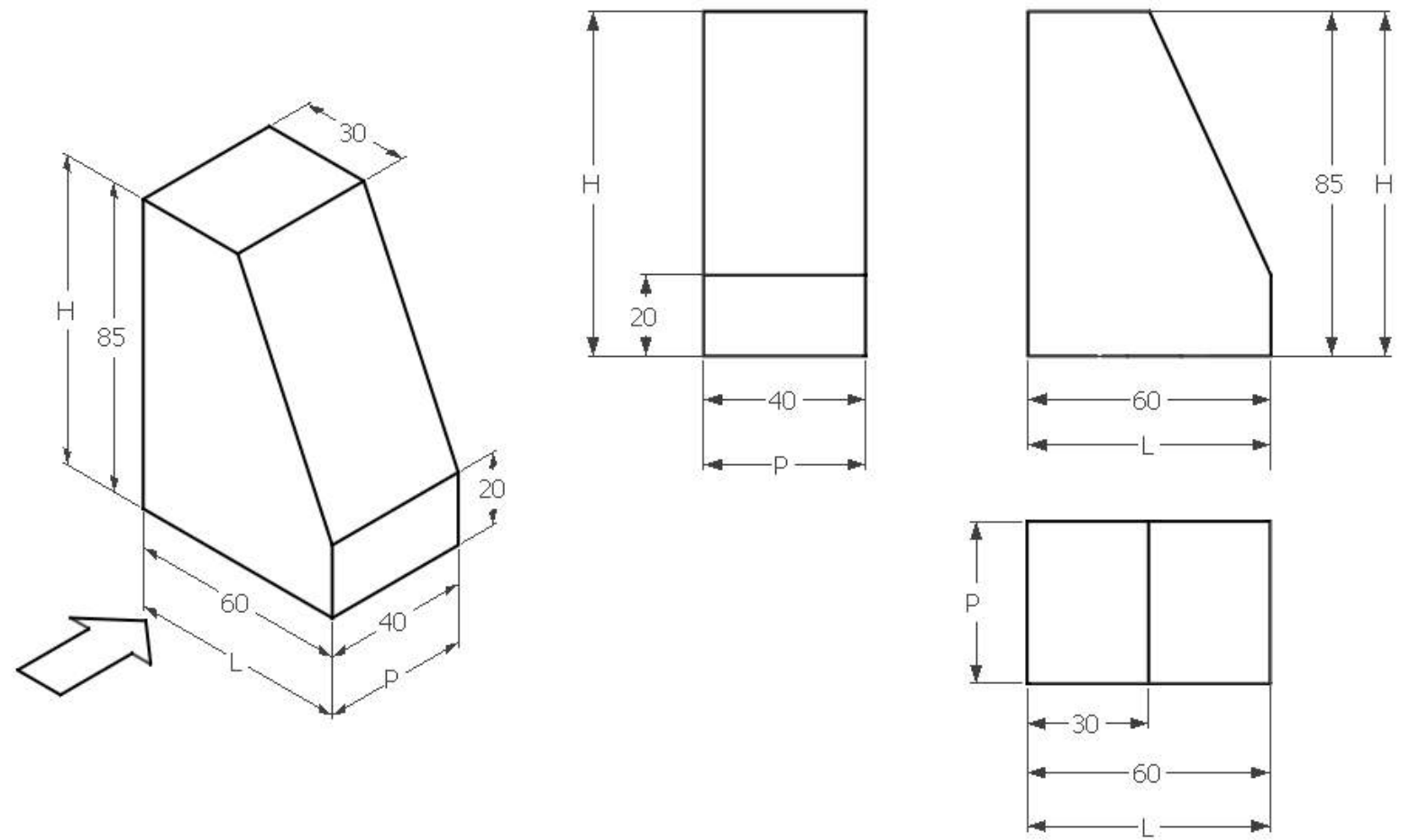

O objeto representado na Figura 6.10 possui uma face que não é paralela a nenhum dos planos de referência, e, portanto, nas suas vistas não aparece a verdadeira grandeza da mesma.

Os objetos, agora, estarão sendo representados apenas no $1^{\circ}$ diedro.

Em Geometria Descritiva constroem-se as figuras, ponto por ponto, em função das respectivas coordenadas (abscissa, afastamento e cota) referidas aos planos de projeção. Em Desenho Técnico, devido à regularidade dos objetos habitualmente representados, utilizam-se para construir as vistas suas próprias dimensões, tomadas paralelamente aos planos de projeção e tendo como referência as faces ou eixos de simetria do próprio objeto (Figura 6.11). 
Figura 6.11 - Vistas ortográficas de um objeto em Desenho Técnico no $1^{\circ}$ diedro.
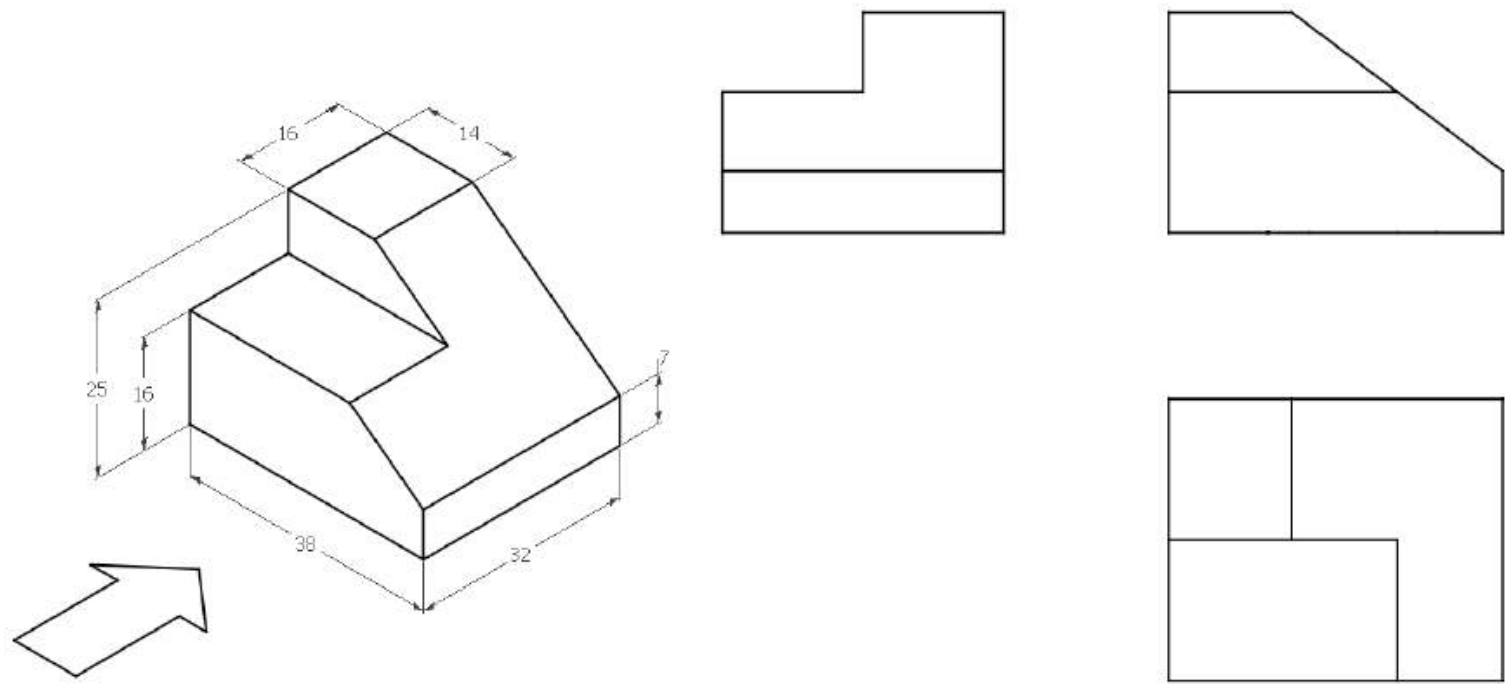

Na obtenção das vistas, os contornos e arestas visíveis são desenhados com linha contínua larga. As arestas e contornos que não podem ser vistos da posição ocupada pelo observador, por estarem ocultos pelas partes que ficam à frente, são representados por linhas tracejadas largas ou estreitas. Com a utilização de linhas tracejadas para aresta invisíveis evita-se, normalmente, com essa convenção, a necessidade de representação de duas vistas opostas de um mesmo contorno, quando o objeto não for simétrico (Figura 6.12). As linhas de centro são eixos de simetria que posicionam o centro de furos ou detalhes com simetria radial, elas são representadas pelo tipo de linha de traço e ponto estreita.

Figura 6.12 - Vistas de um objeto onde na lateral esquerda há uma aresta invisível no $1^{\text {o }}$ diedro.
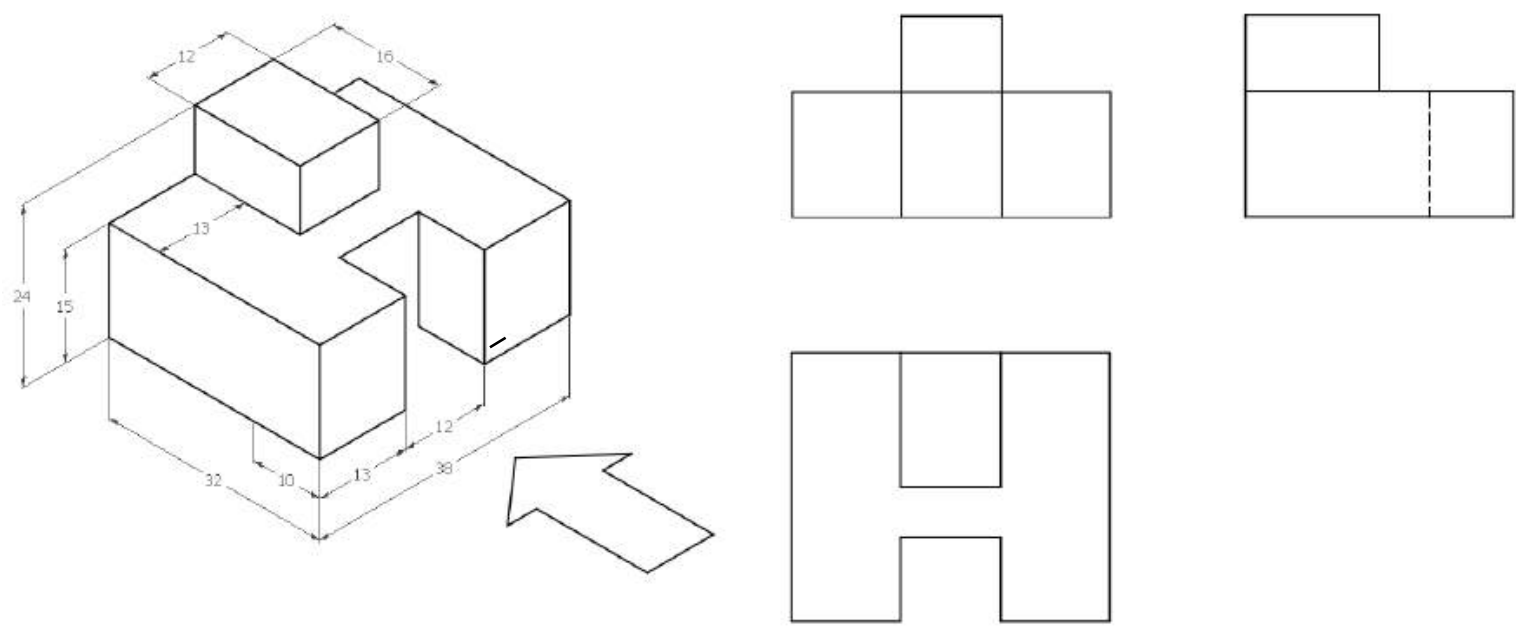

Catapan, Strobel e Santana (2020) 
A representação da vista oposta a uma vista habitual é necessária quando a quantidade e a complexidade dos detalhes invisíveis e sua coincidência parcial com linhas visíveis impedem uma fácil identificação dos mesmos.

\subsection{EVITAR VISTAS REDUNDANTES}
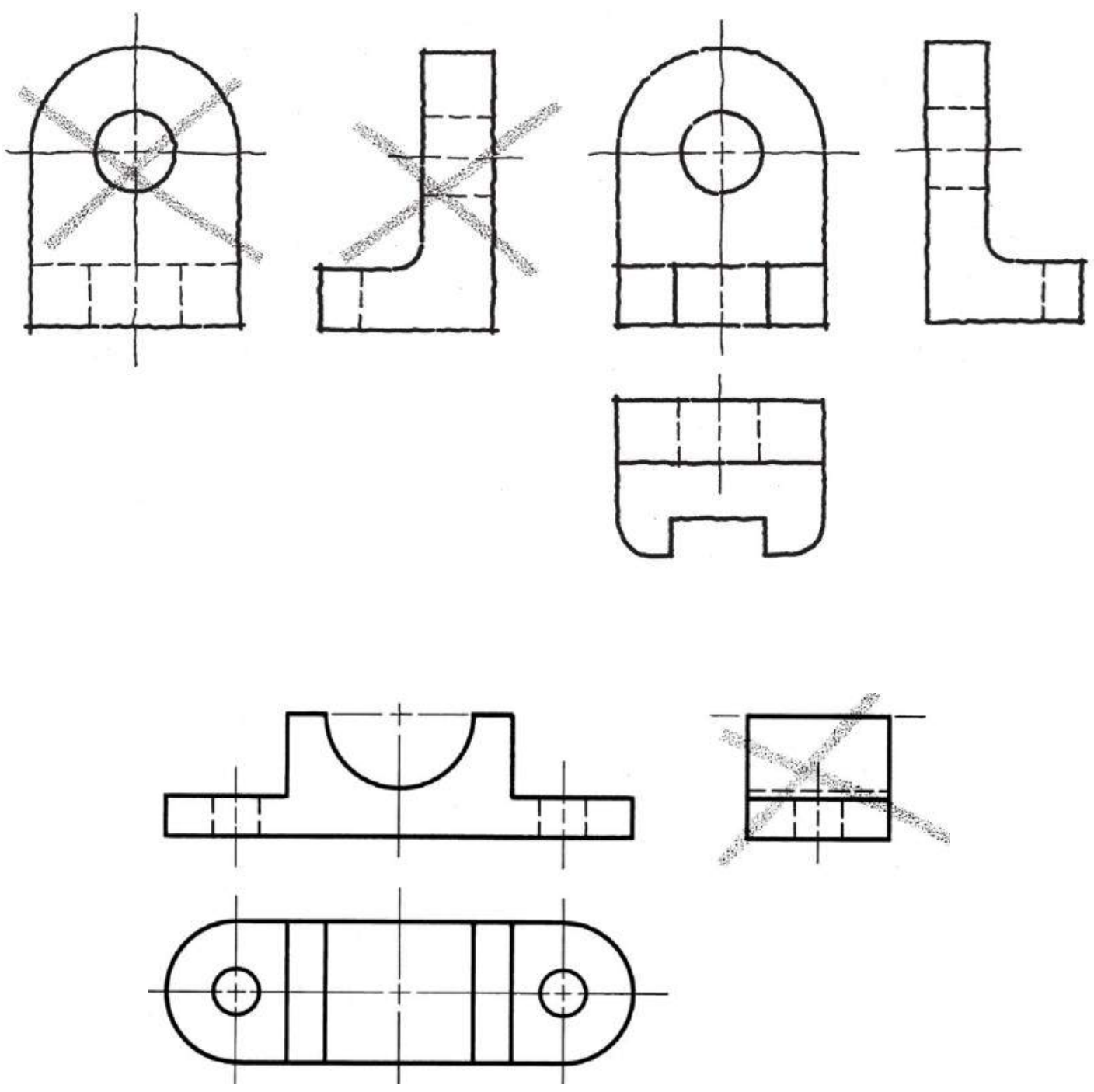

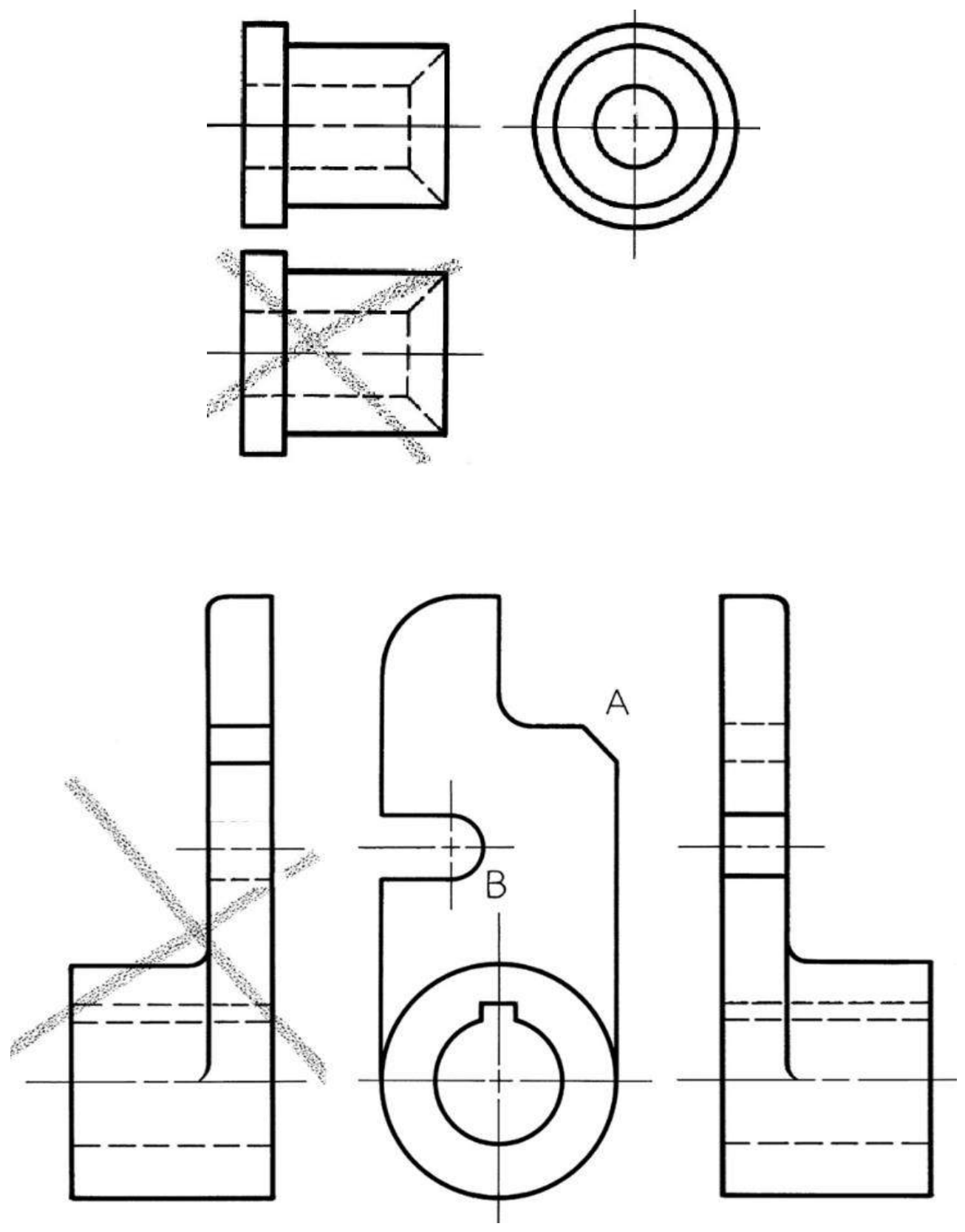

\subsection{ANÁLISE DA FORMA DOS OBJETOS}

Todos os objetos podem ser considerados como compostos de sólidos geométricos elementares, tais como: prismas, cilindros, cones, etc, utilizados de maneira positiva (adicionados) ou negativa (subtraídos) (Figuras 6.13 e 6.14).

Antes de representar um objeto por meio de suas vistas ortográficas deve-se analisar quais os sólidos geométricos elementares que adicionados ou subtraídos levam à sua obtenção. As vistas ortográficas desse objeto serão desenhadas obedecendo aquela sequência de operações de montagem ou corte. 


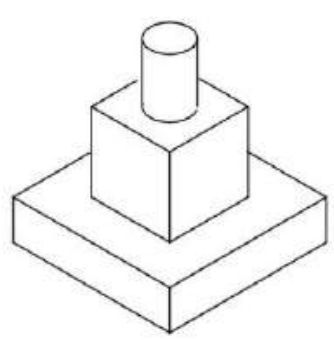

Figura 6.13 - Objeto composto de maneira positiva
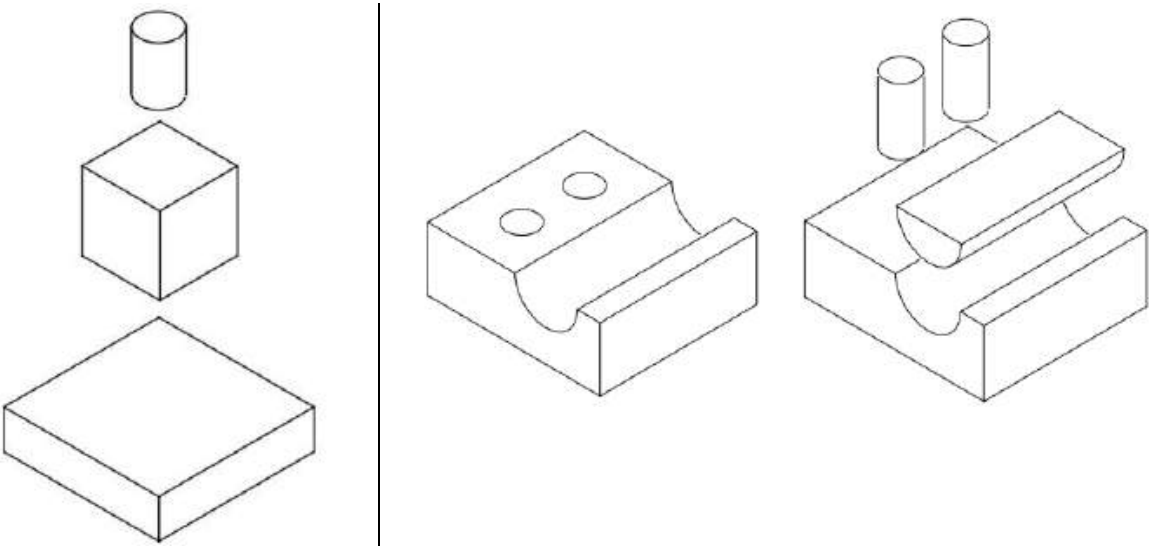

Figura 6.14 - Objeto composto de maneira negativa

\subsection{LEITURA DE VISTAS ORTOGRÁFICAS}

A representação de um objeto no sistema de vistas ortográficas somente será compreendida de modo inequívoco se cada vista for interpretada em conjunto e coordenadamente com as outras.

A leitura das vistas ortográficas é muito auxiliada pela aplicação de três regras fundamentais:

1' Regra do alinhamento: as projeções de um mesmo elemento do objeto nas vistas adjacentes estão sobre o mesmo alinhamento, isto é, sobre a mesma linha de chamada (Figura 6.15);

2ㄹ Regra das figuras contíguas: as figuras contíguas de uma mesma vista correspondem a faces do objeto que não podem estar situadas no mesmo plano (Figura 6.16);

3. Regra da configuração: uma face plana do objeto projeta-se com a sua configuração ou como um segmento de reta. No primeiro caso a face é inclinada ou paralela ao plano de projeção, e, no segundo caso é perpendicular a ele (Figura 6.17). 
Figura 6.15 - Regra do alinhamento das vistas ortográficas de um objeto.

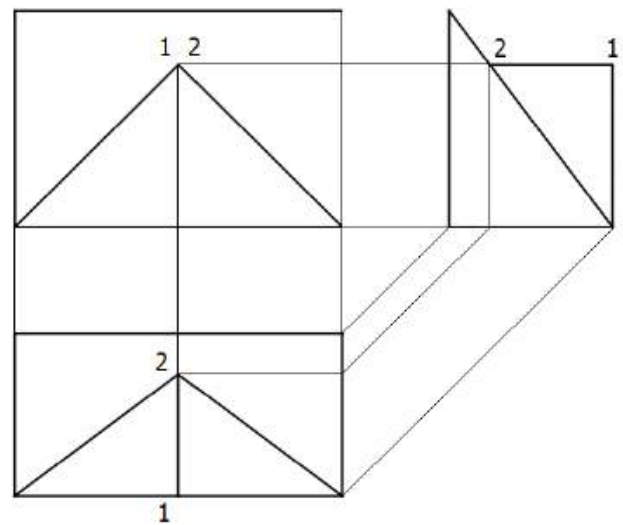

Figura 6.16 - Regra das figuras contíguas das vistas ortográficas de um objeto.
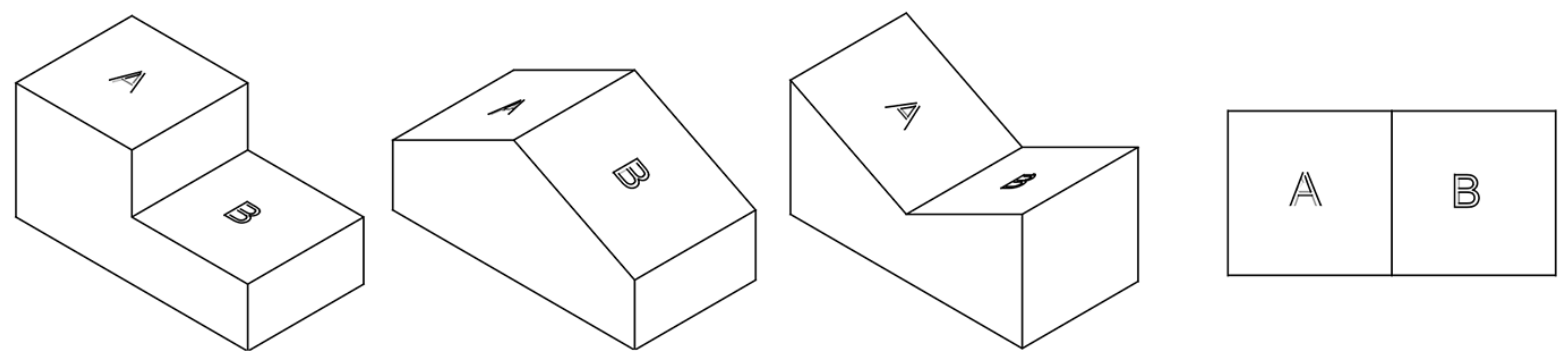

Figura 6.17 - Regra da configuração das projeções de uma face de um objeto.

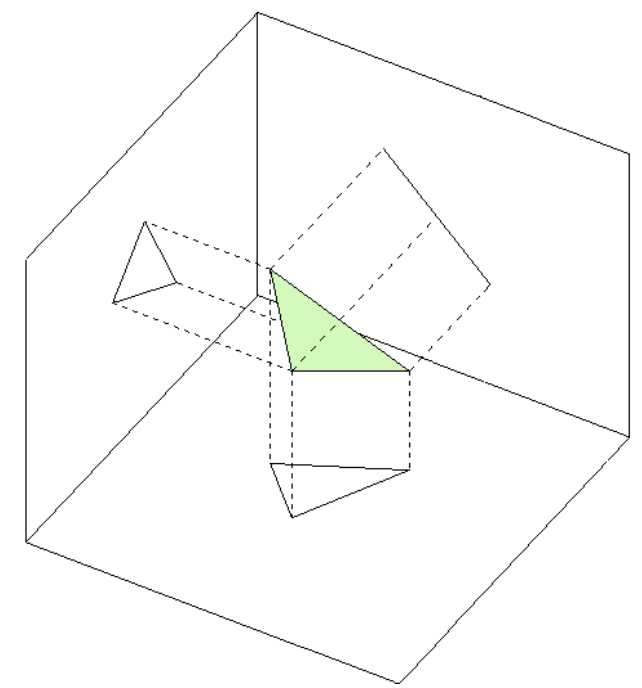

Além dessas três regras básicas, é útil saber que, usando as projeções no $1^{\circ}$ diedro, qualquer detalhe voltado para o observador numa determinada vista aparecerá mais afastados dela em uma vista adjacente. Se as projeções forem executadas no $3^{\circ}$ diedro, o mesmo detalhe estará mais próximo. 


\section{EXERCÍCIOS DE VISTAS ORTOGRÁFICAS}

1) Numere as projeções ortogonais correspondentes a cada perspectiva:

a

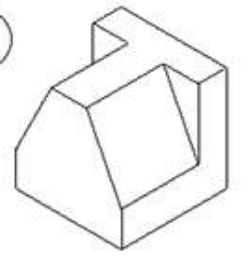

(b)

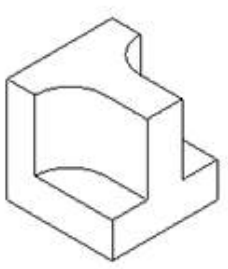

(c)

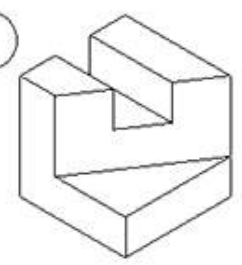

(d)

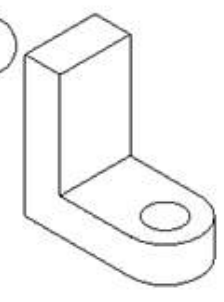

(e)

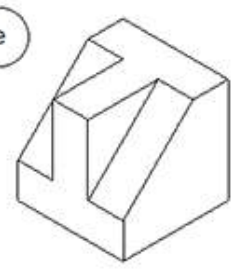

(f)

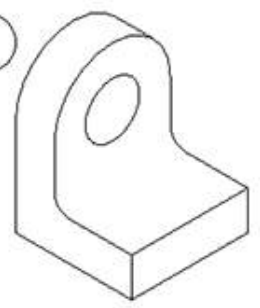

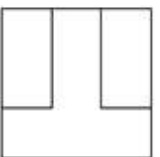

0
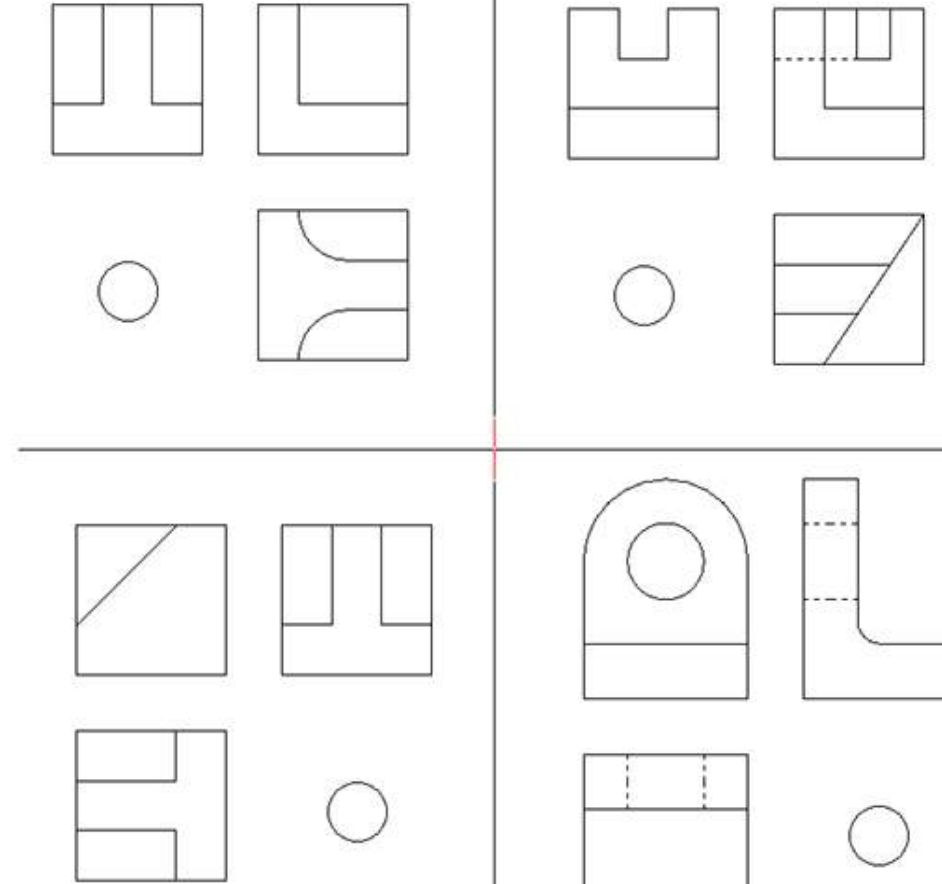

(
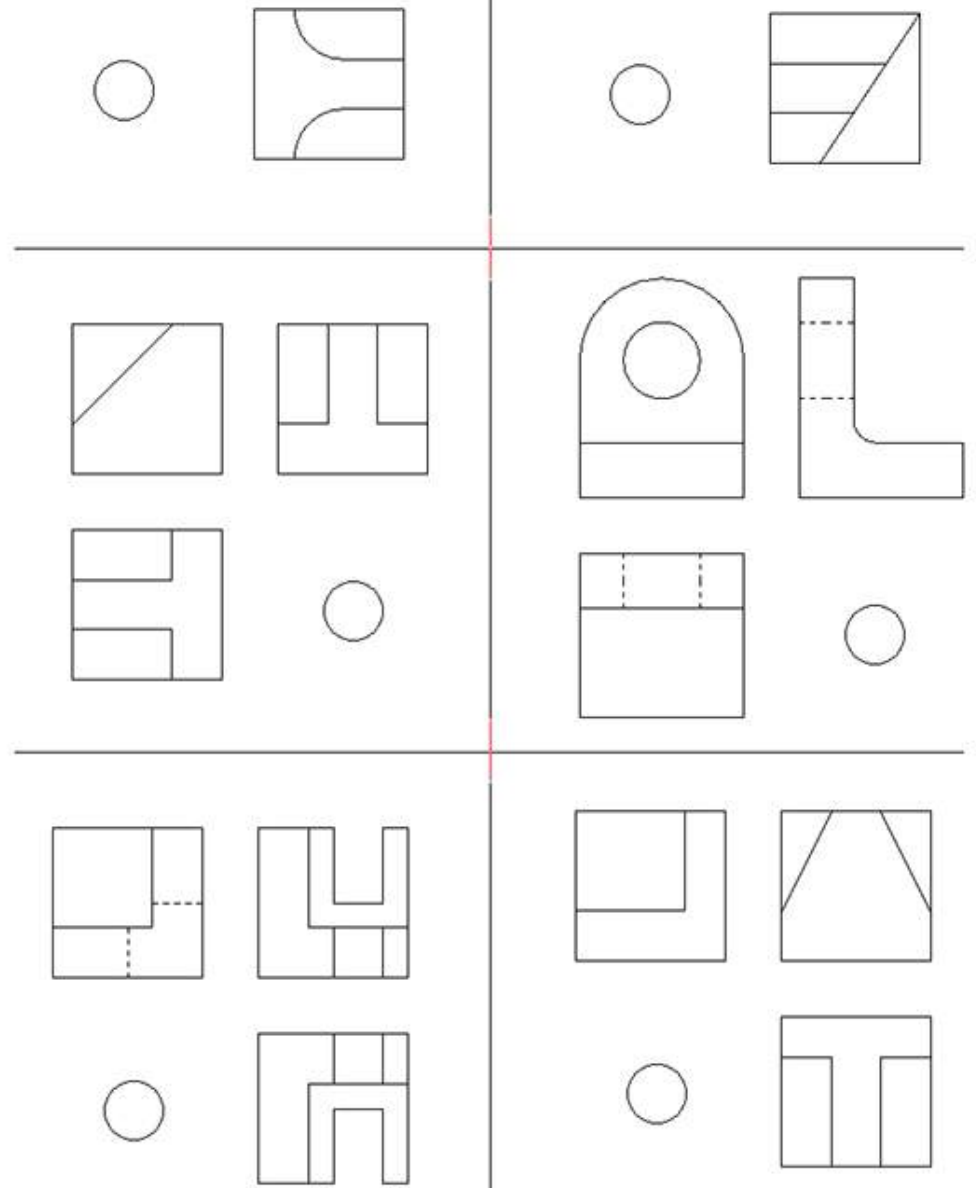

()
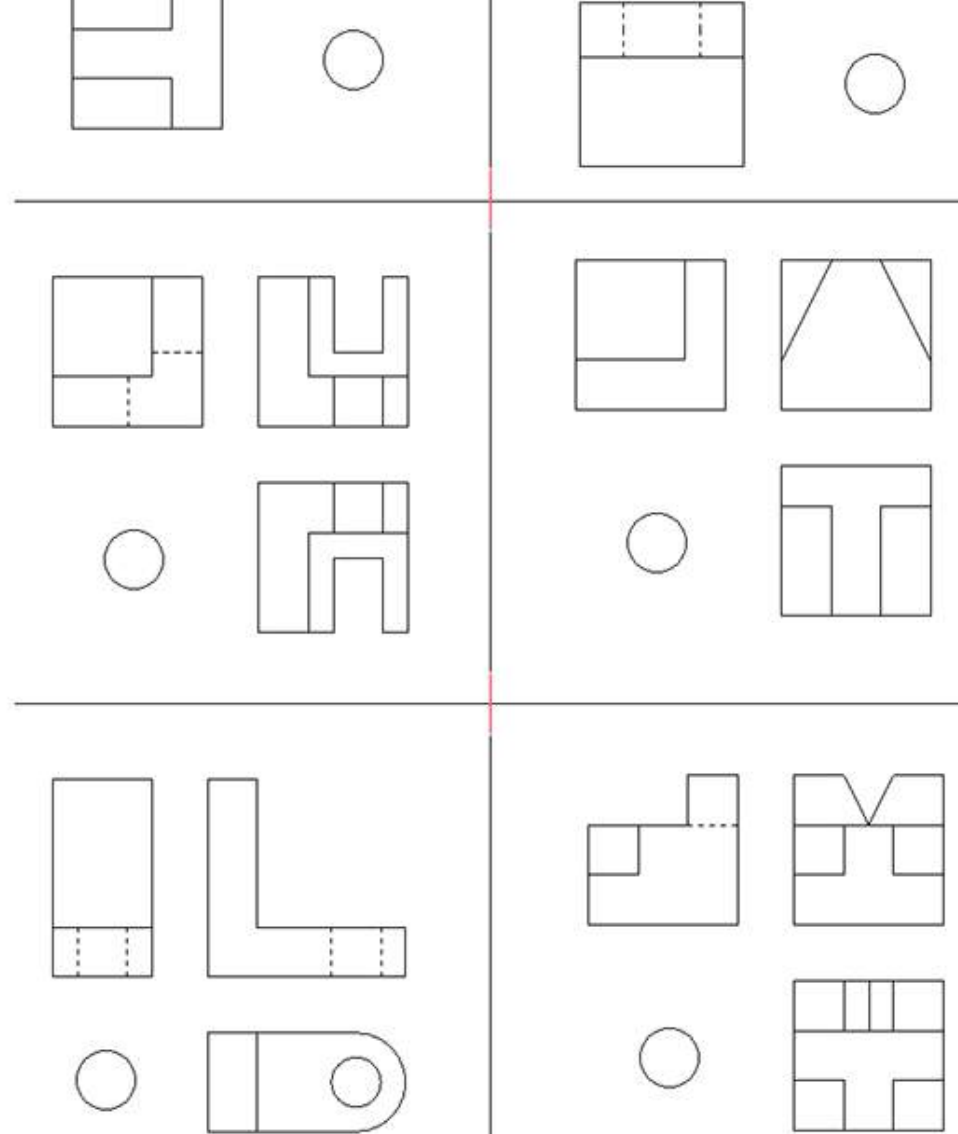

()

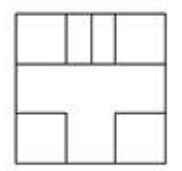


(9)

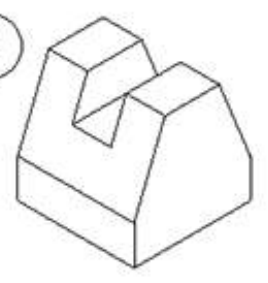

(n)

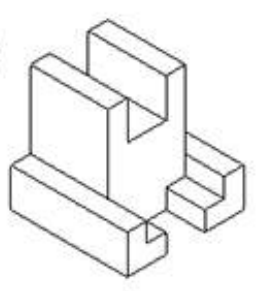

(1)

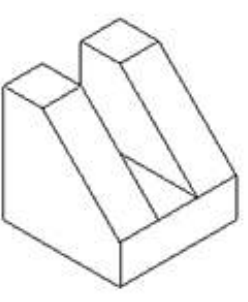

(i)

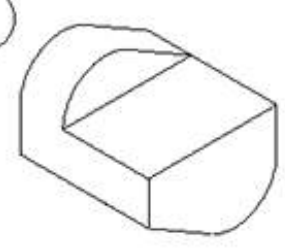

()

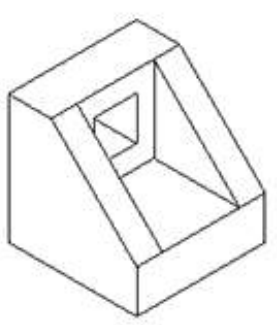

(1)

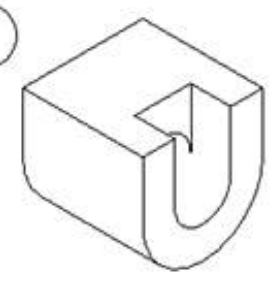

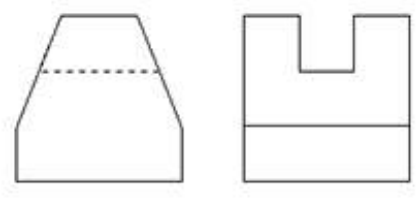

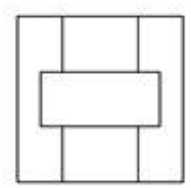

$\bigcirc$
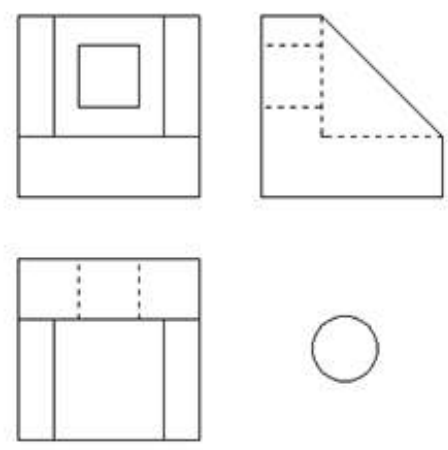

$\bigcirc$

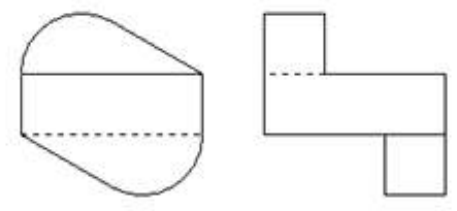

(

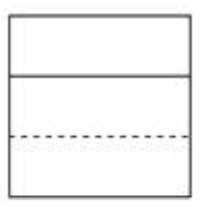

$\bigcirc$
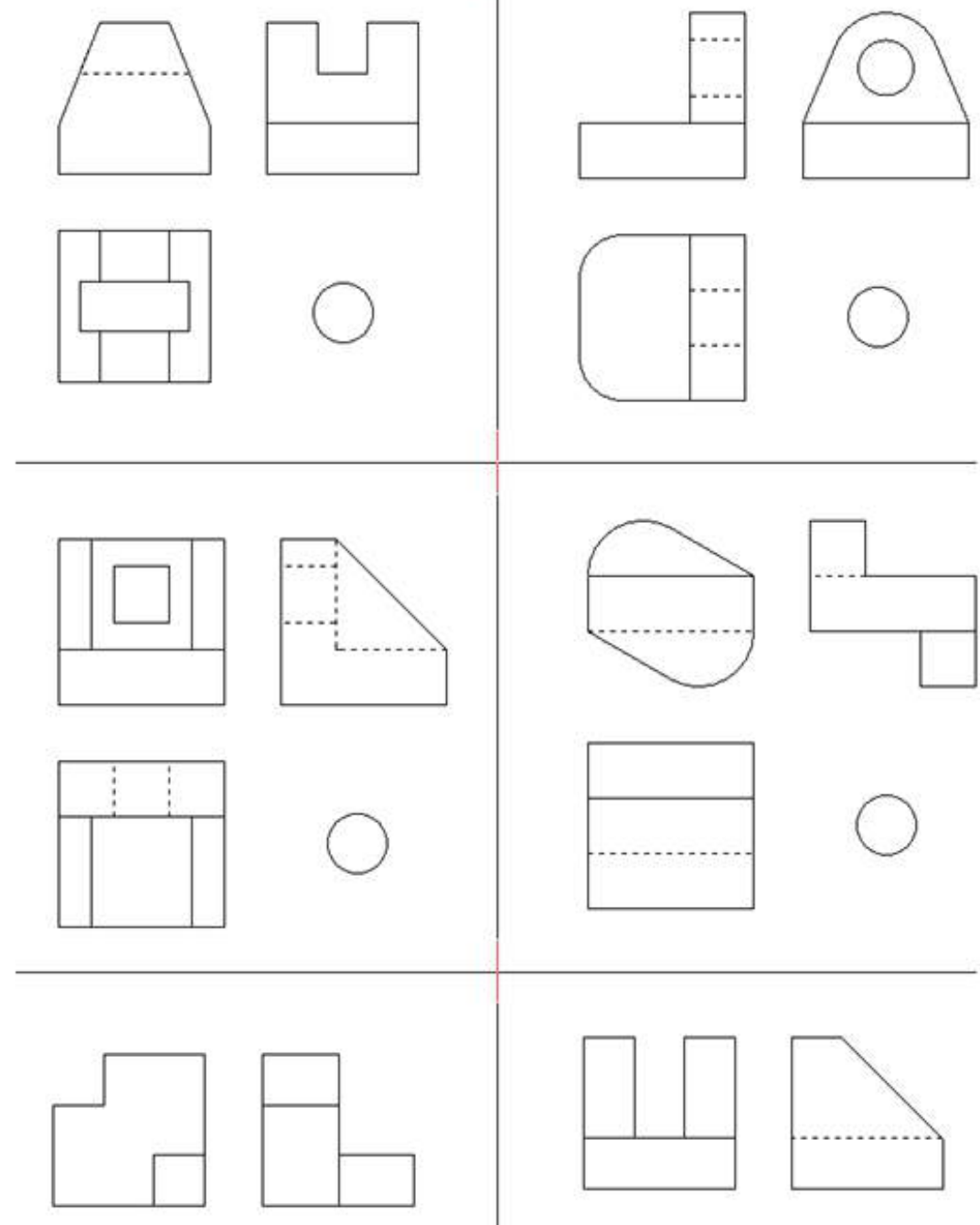

$\bigcirc$
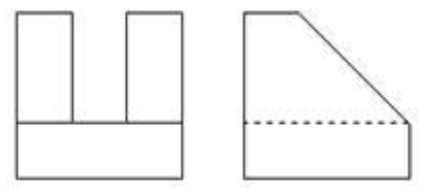

$\bigcirc$
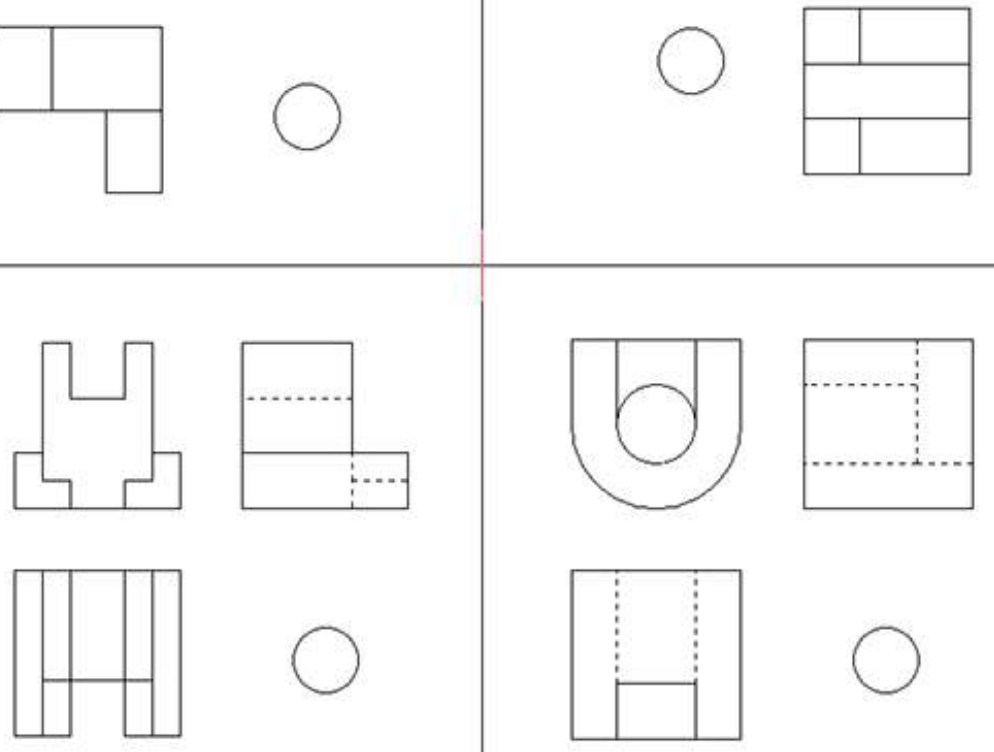

○

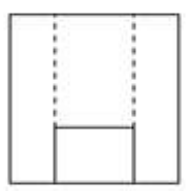

○ 
2) Identifique a Vista de Frente, a Vista Superior, a Vista Lateral Esquerda e a Vista Lateral Direita nas projeções dadas.

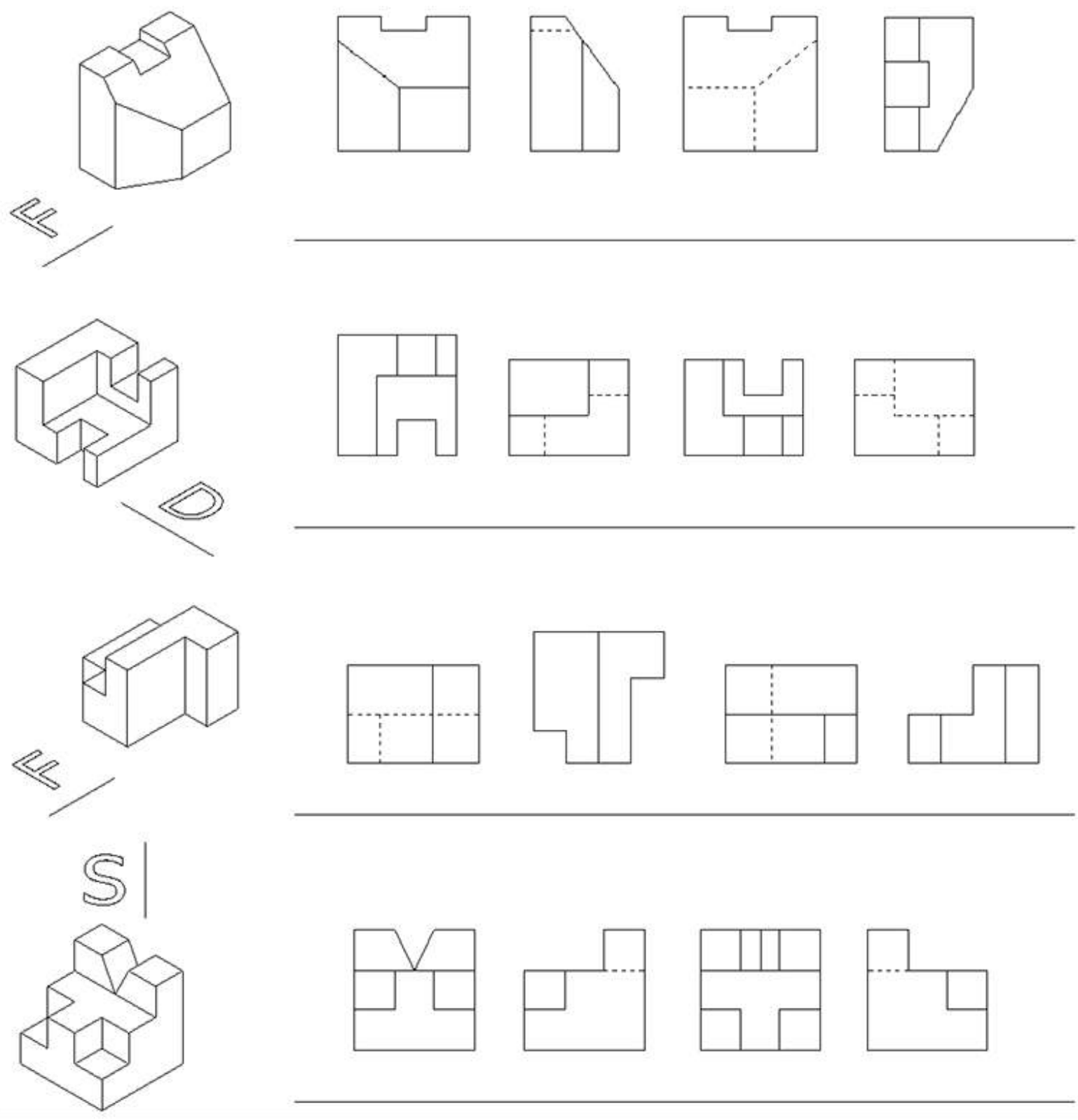


3) Identifique a Vista de Frente, a Vista Superior, a Vista Lateral Esquerda e a Vista Lateral Direita nas projeções dadas.
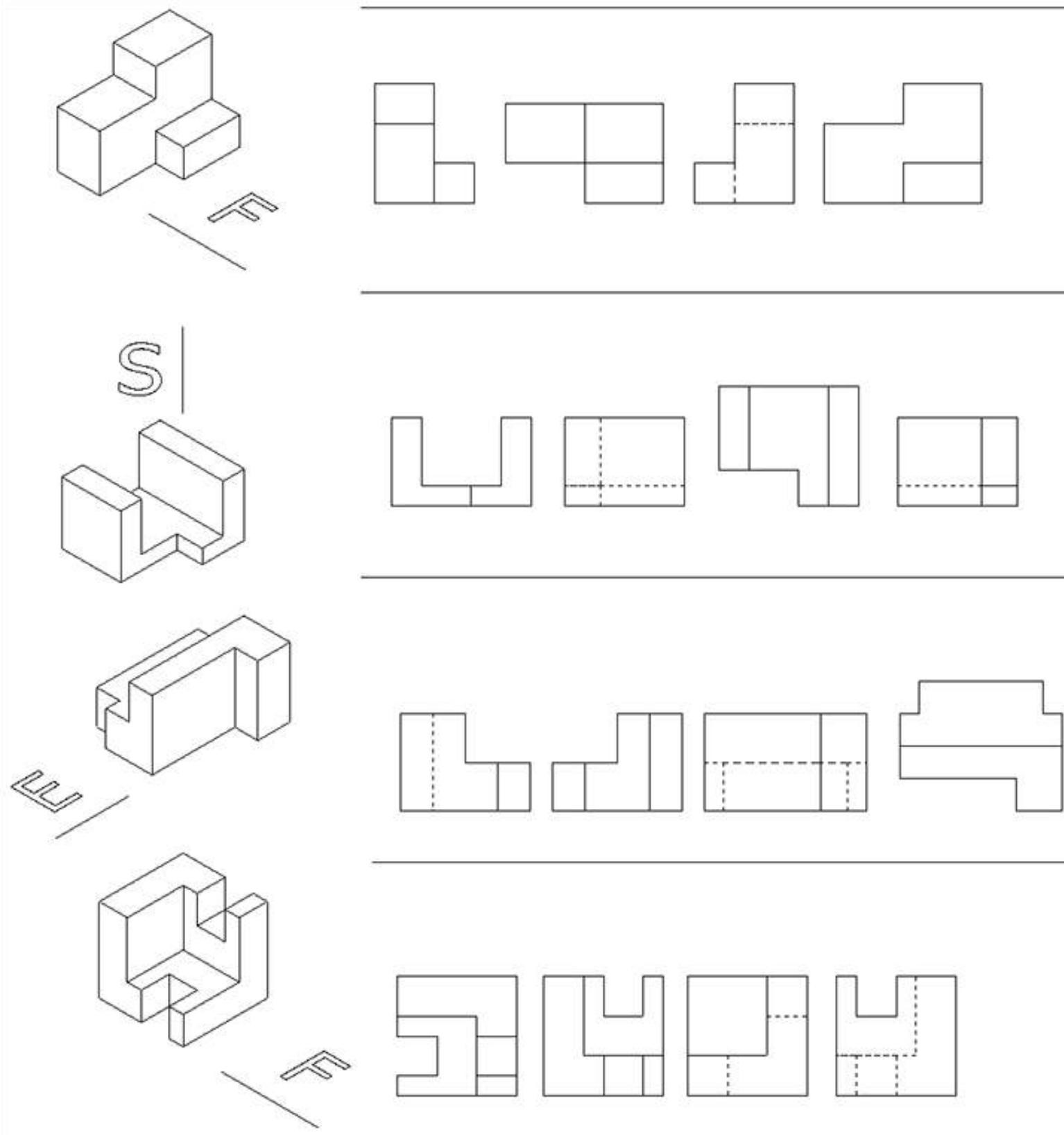
4) Identifique a Vista de Frente, a Vista Superior, a Vista Lateral Esquerda e a Vista Lateral Direita nas projeções dadas.

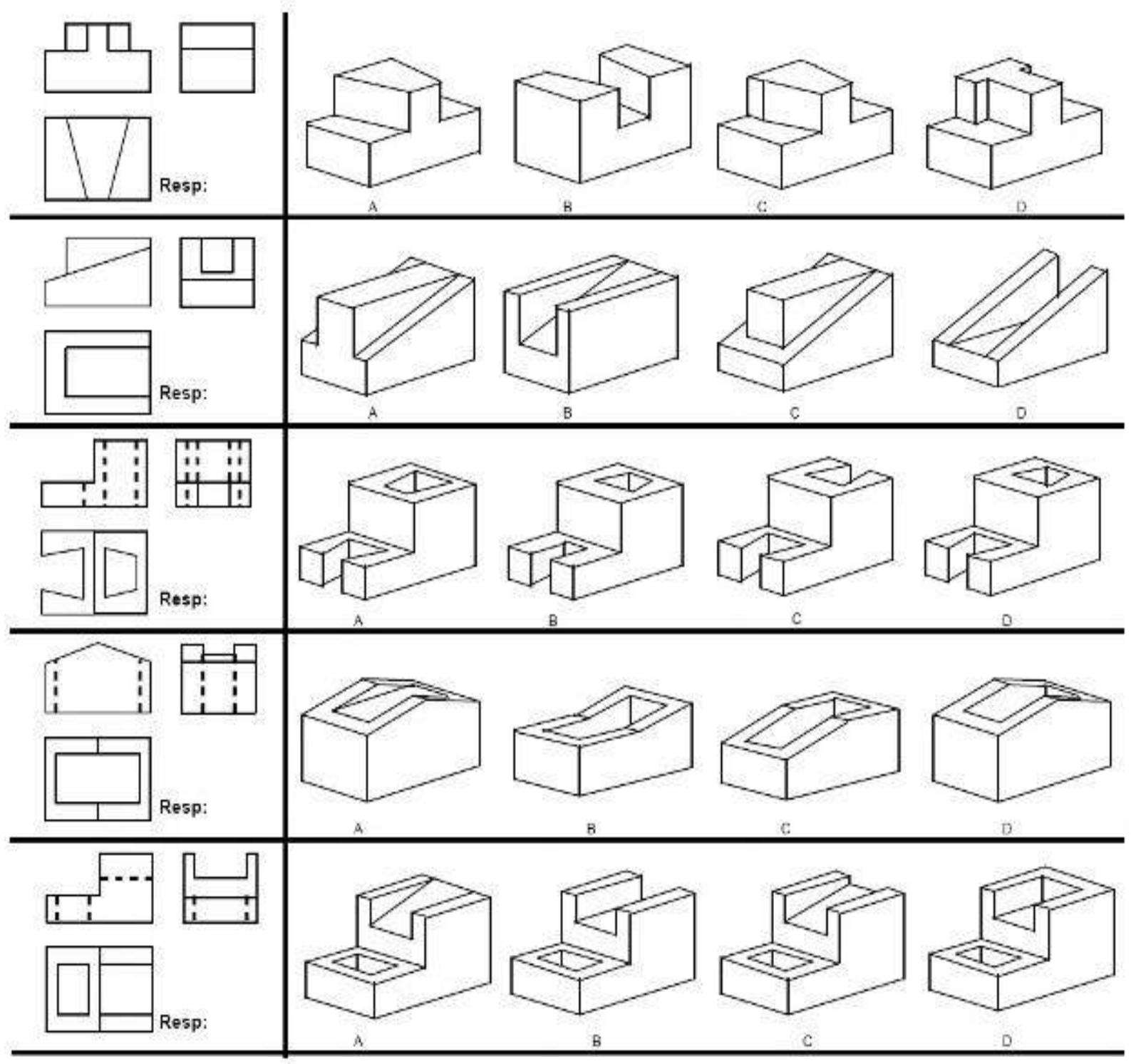


5) Escreva nos modelos representados em perspectiva isométrica as letras dos desenhos técnicos que correspondem às suas faces.
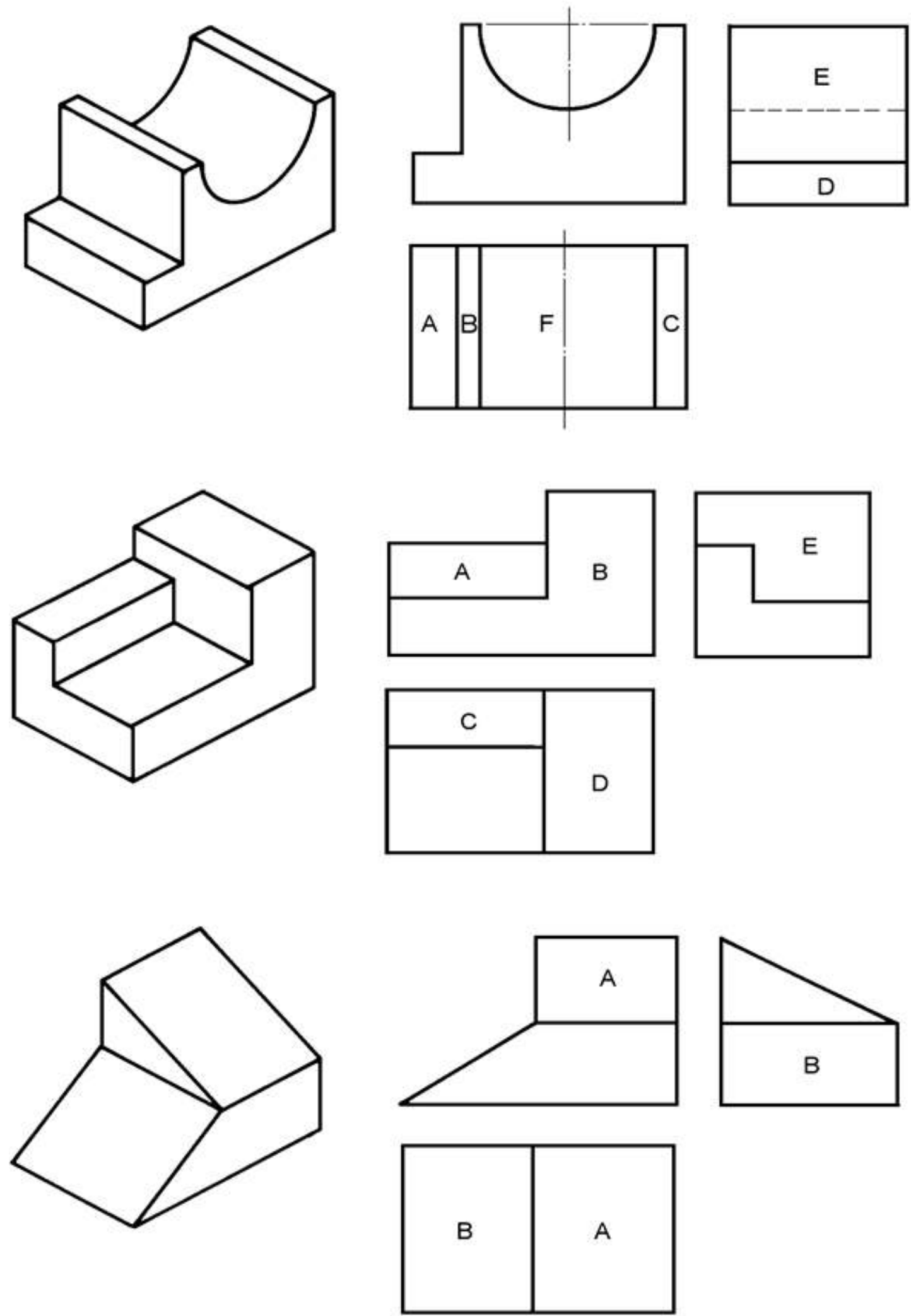
6) Escreva nas projeções ortográficas as letras que correspondem as letras dadas na Perspectiva Isométrica ao lado.
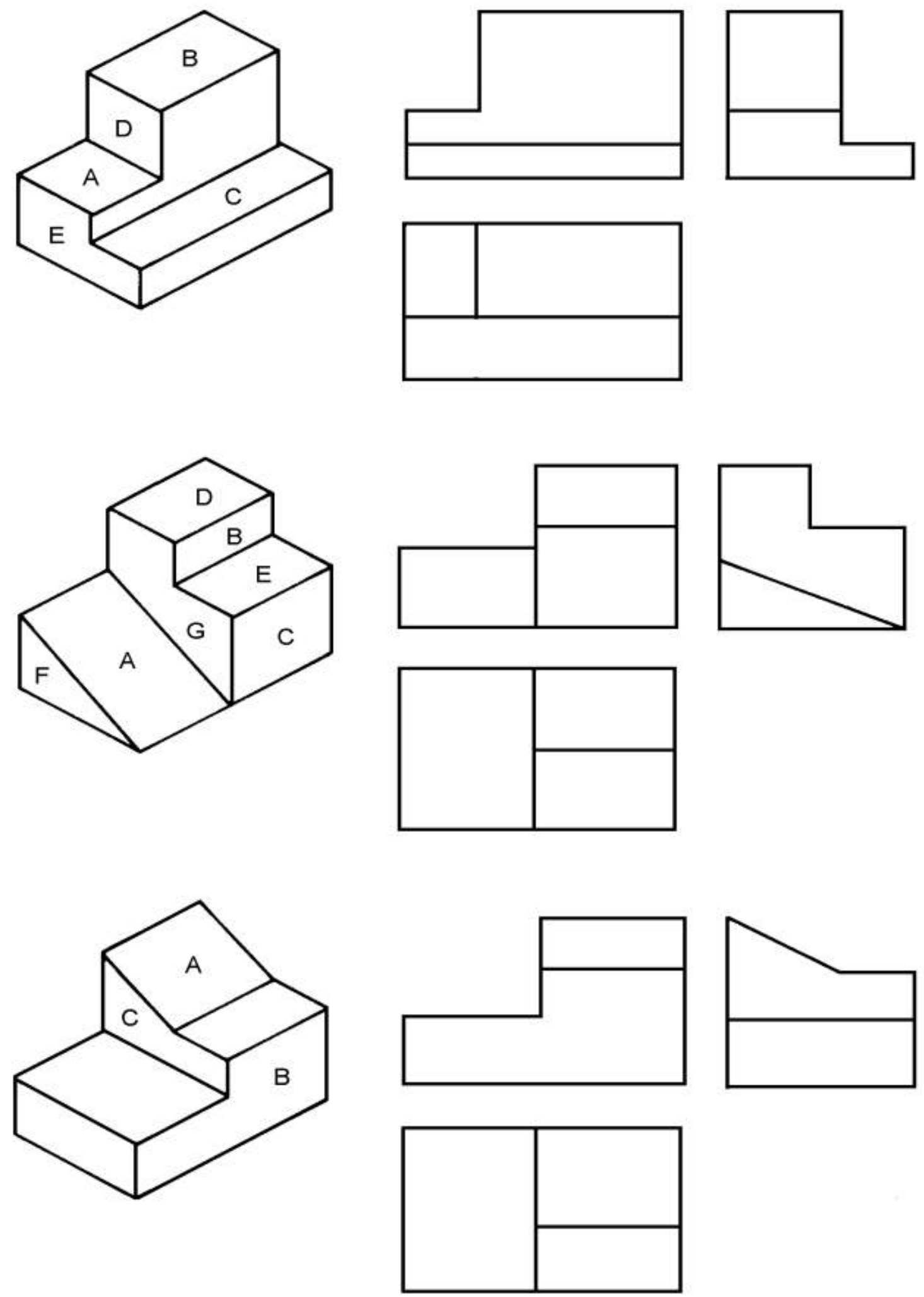
7) Para cada peça em projeção há quatro perspectivas, porém só uma é correta. Assinale com $\mathrm{X}$ a perspectiva que corresponde à peça.
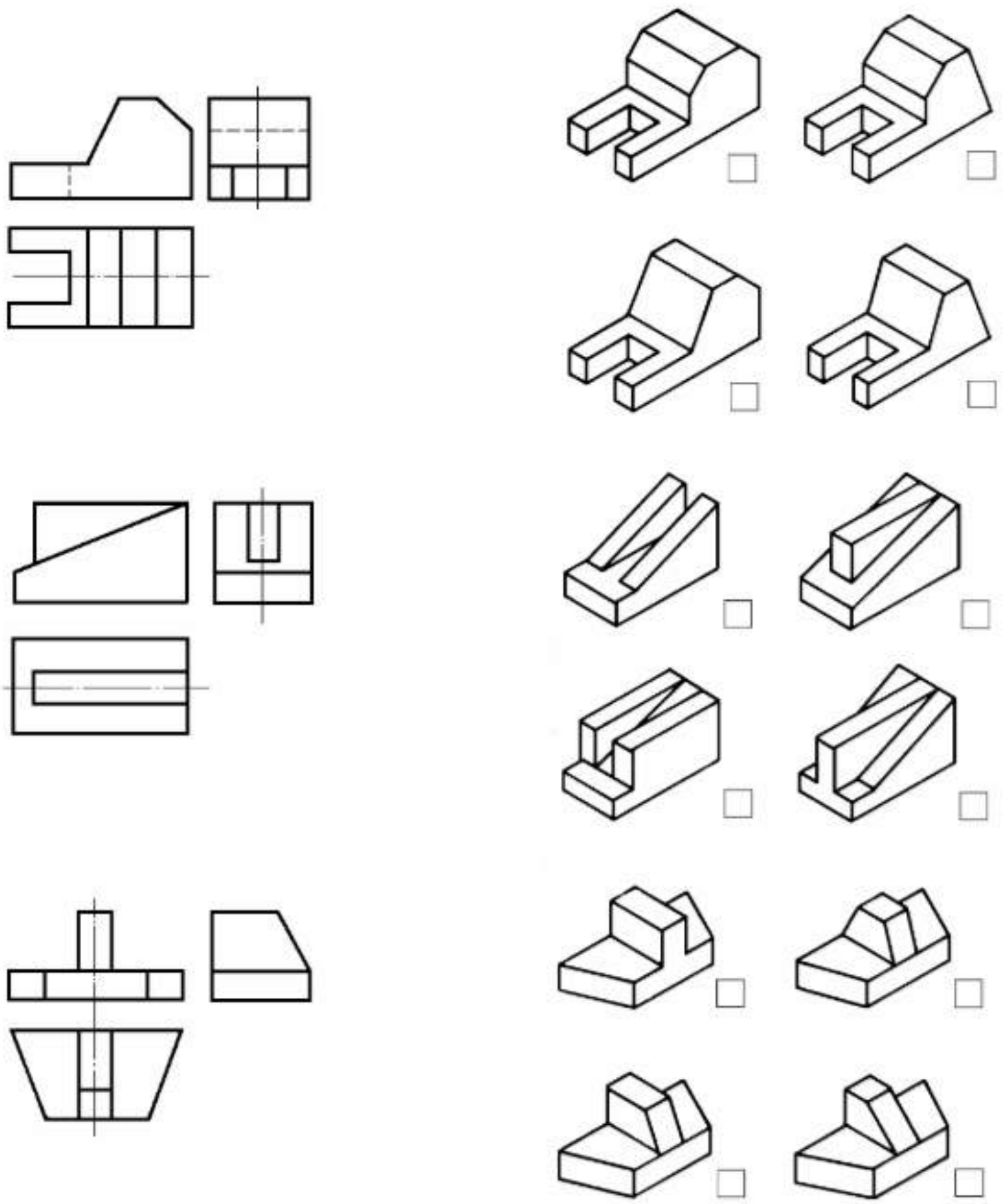

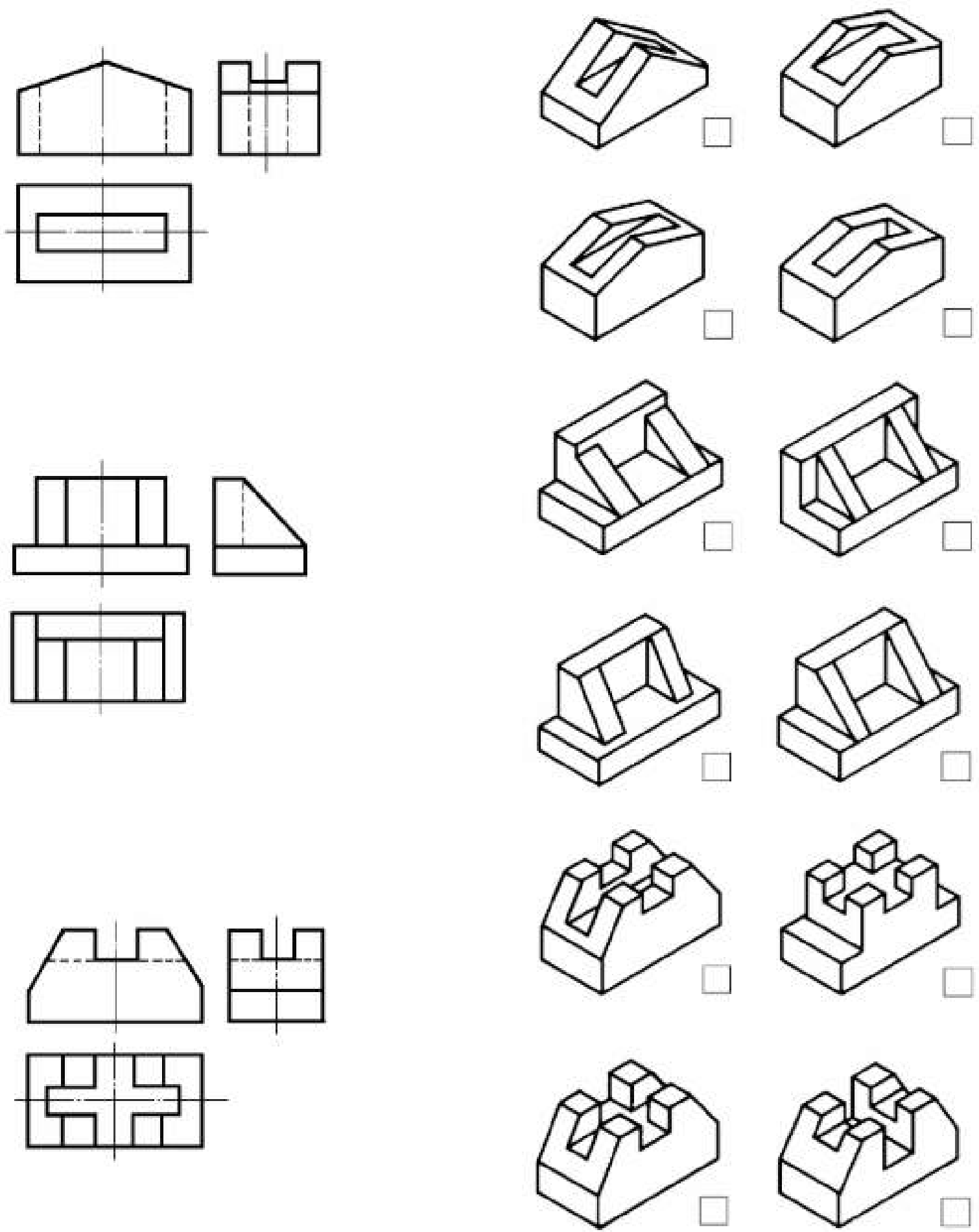
8) Procure entre as projeções abaixo as vistas frontal e superior que se relacionam entre si e anote os números correspondentes. No exemplo abaixo encontra-se a perspectiva da peça representada pelas projeções 1 e 15.

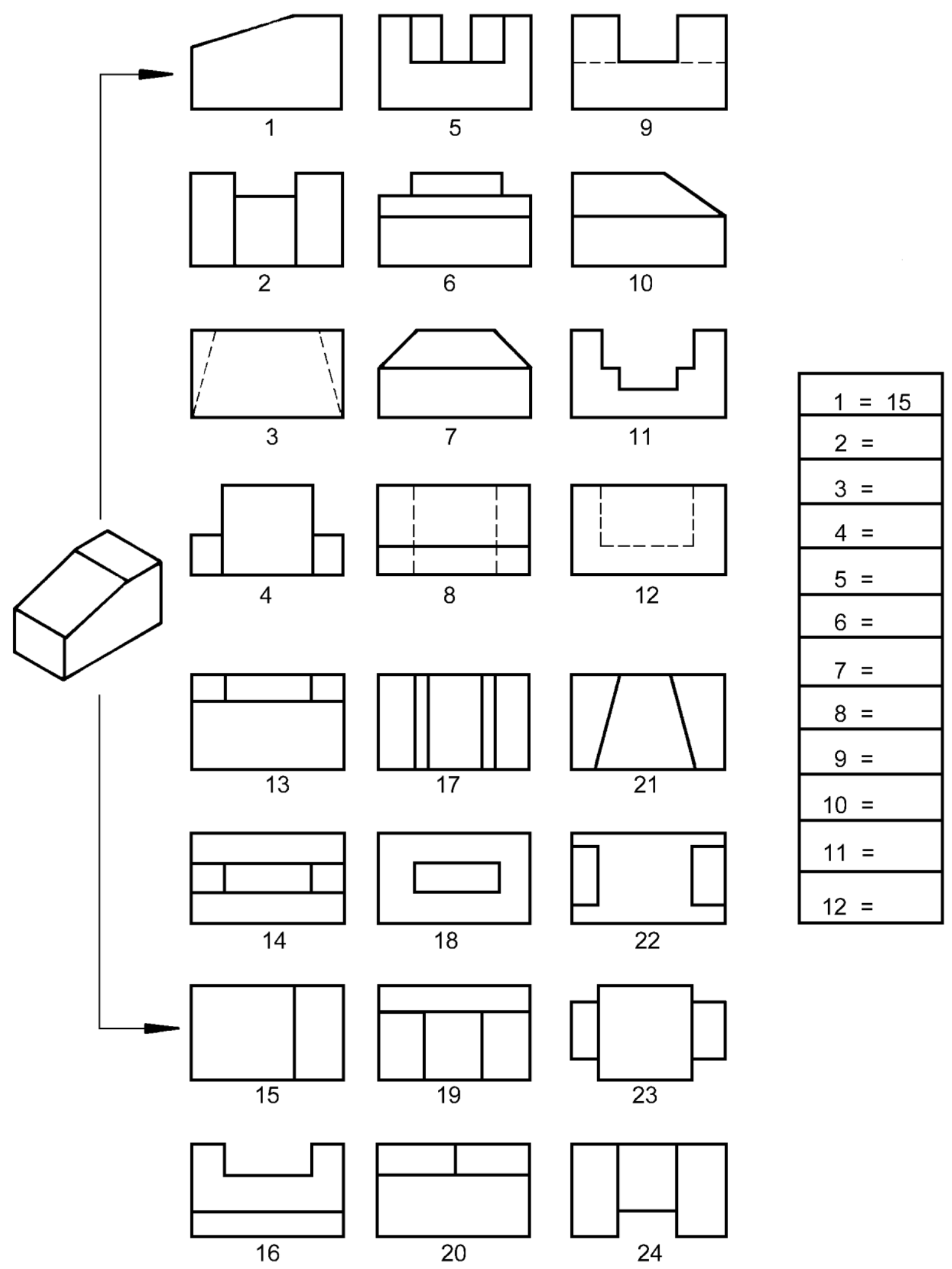


9) Procure entre as projeções abaixo as vistas frontal e lateral esquerda que se relacionam entre si e anote os números correspondentes. Nos exemplos abaixo encontra-se a perspectiva da peça representada pelas projeções 1 e 14.
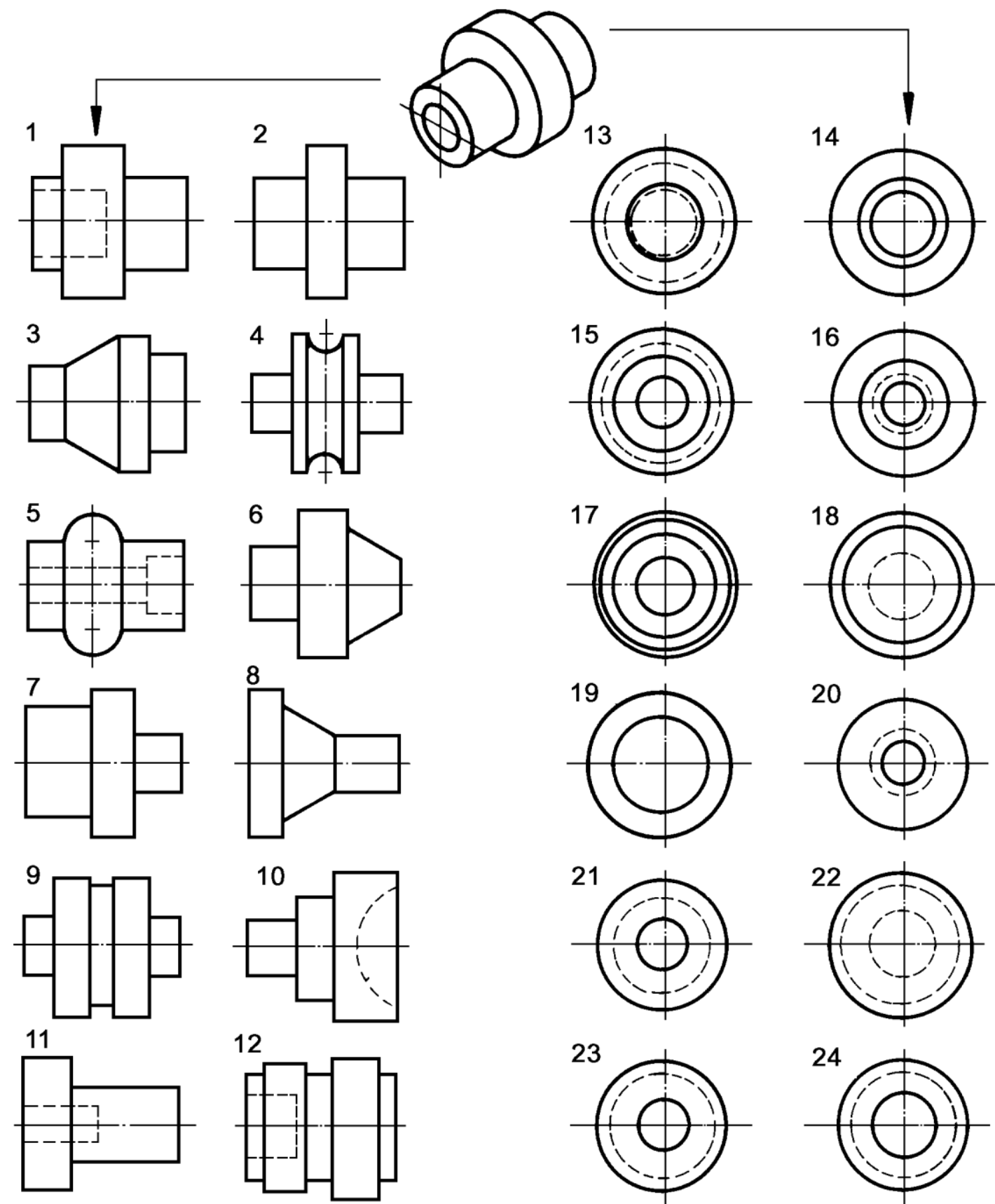
12
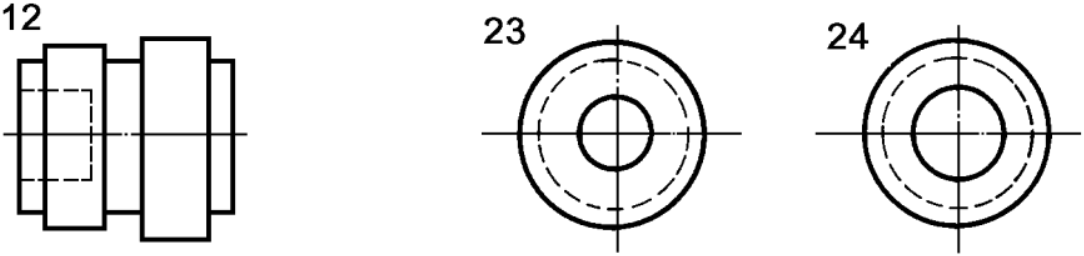

\begin{tabular}{|l|l|l|l|l|l|}
\hline $1=14$ & $2=$ & $3=$ & $4=$ & $5=$ & $6=$ \\
\hline $7=$ & $8=$ & $9=$ & $10=$ & $11=$ & $12=$ \\
\hline
\end{tabular}


10) Qual vista frontal representa corretamente a perspectiva dada?
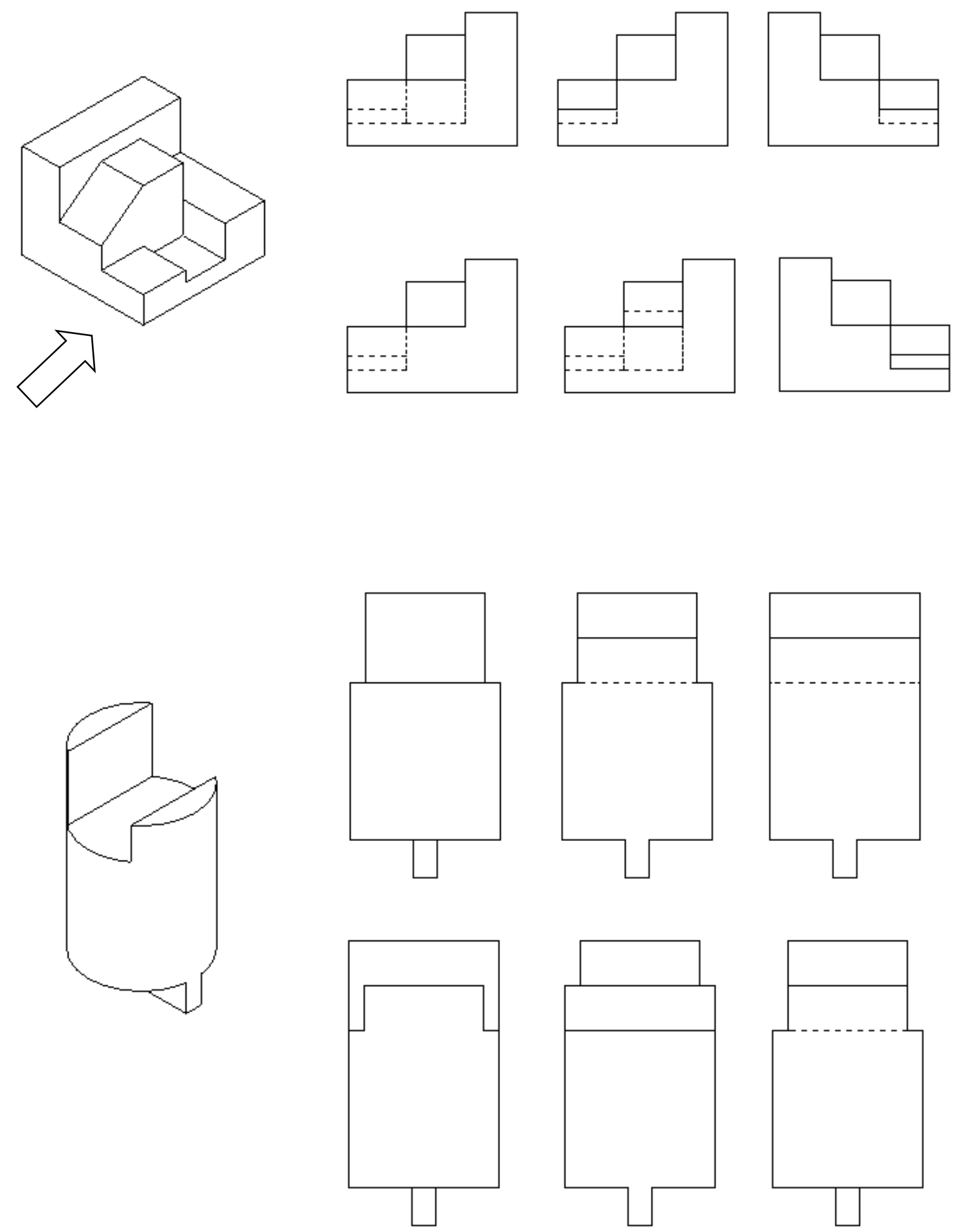
11) Qual vista superior representa corretamente o objeto?
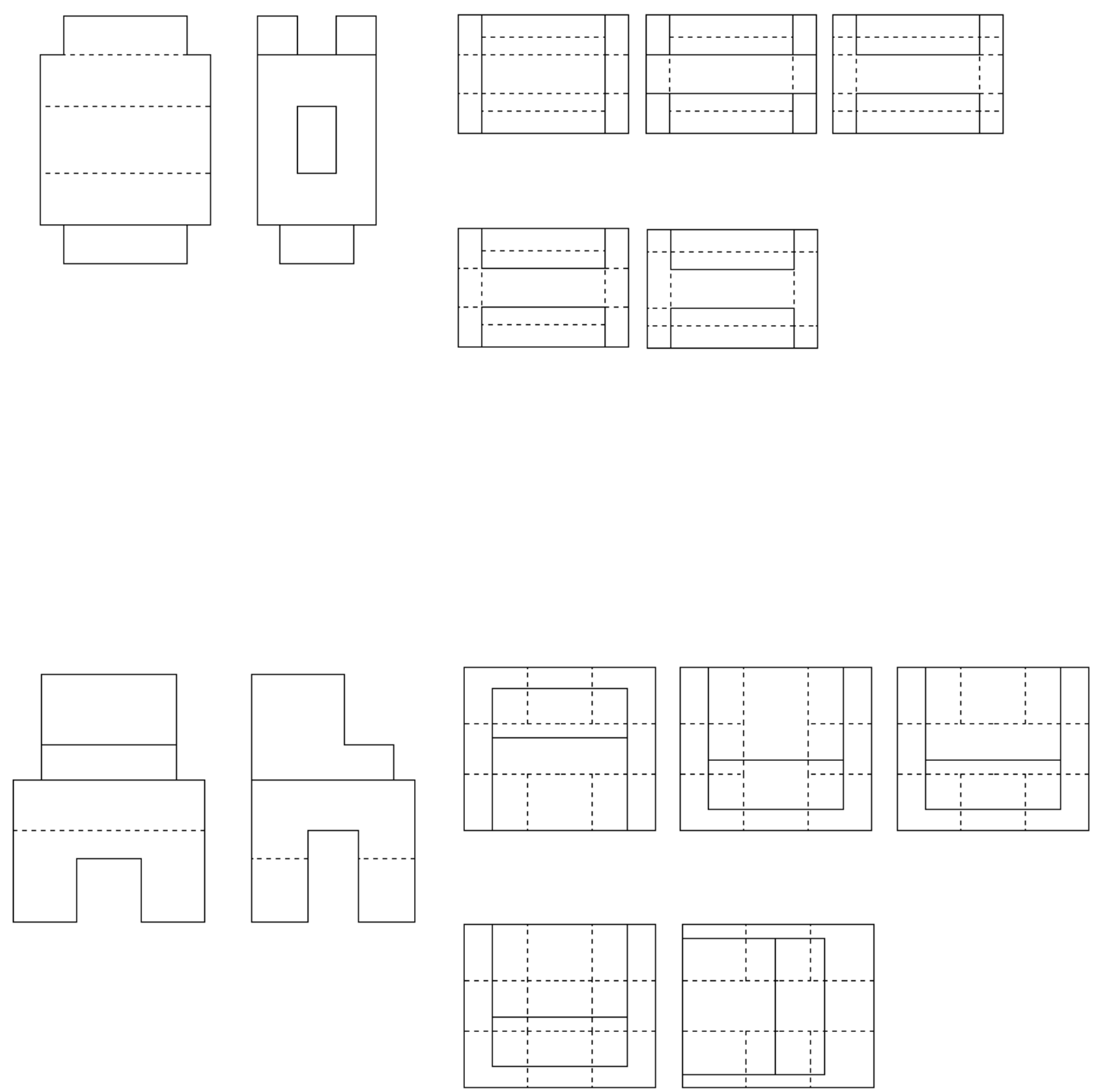
12) Desenhar as vistas ortográficas: VF, VS e VLE.

a)
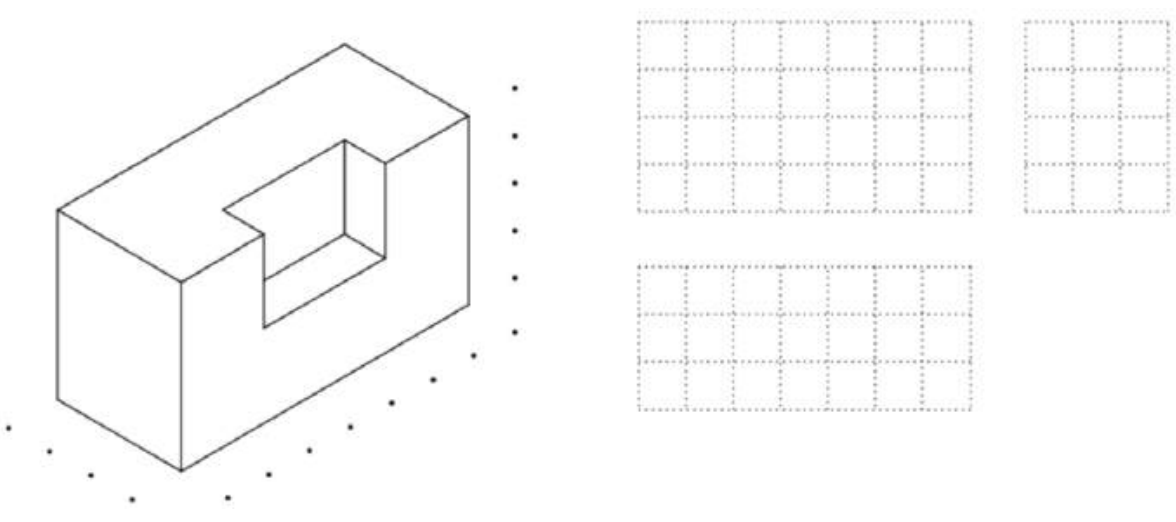

b)
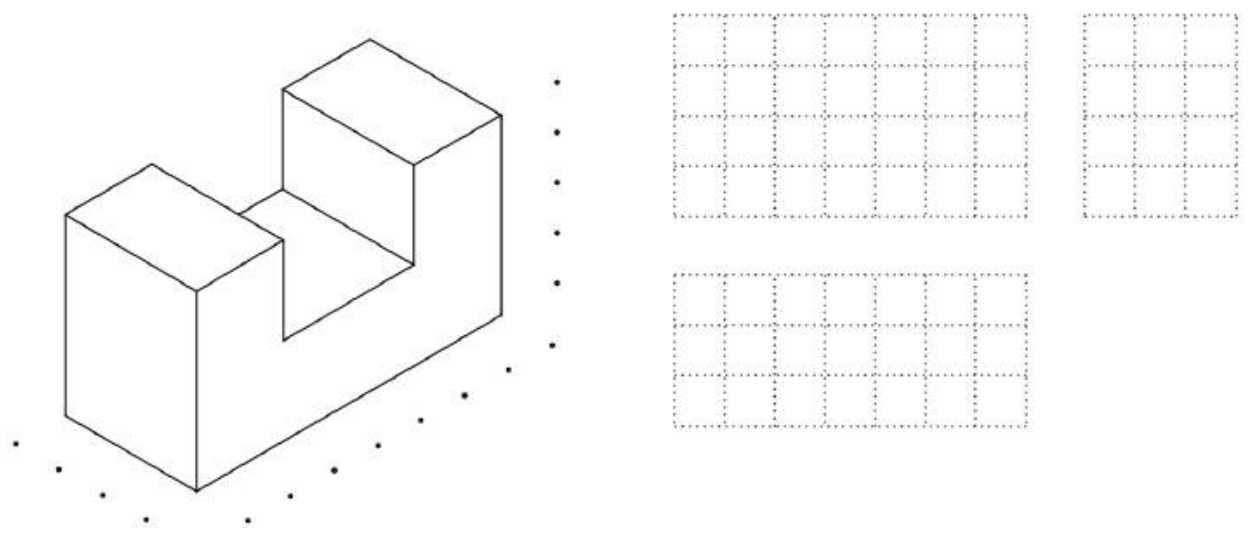

c)
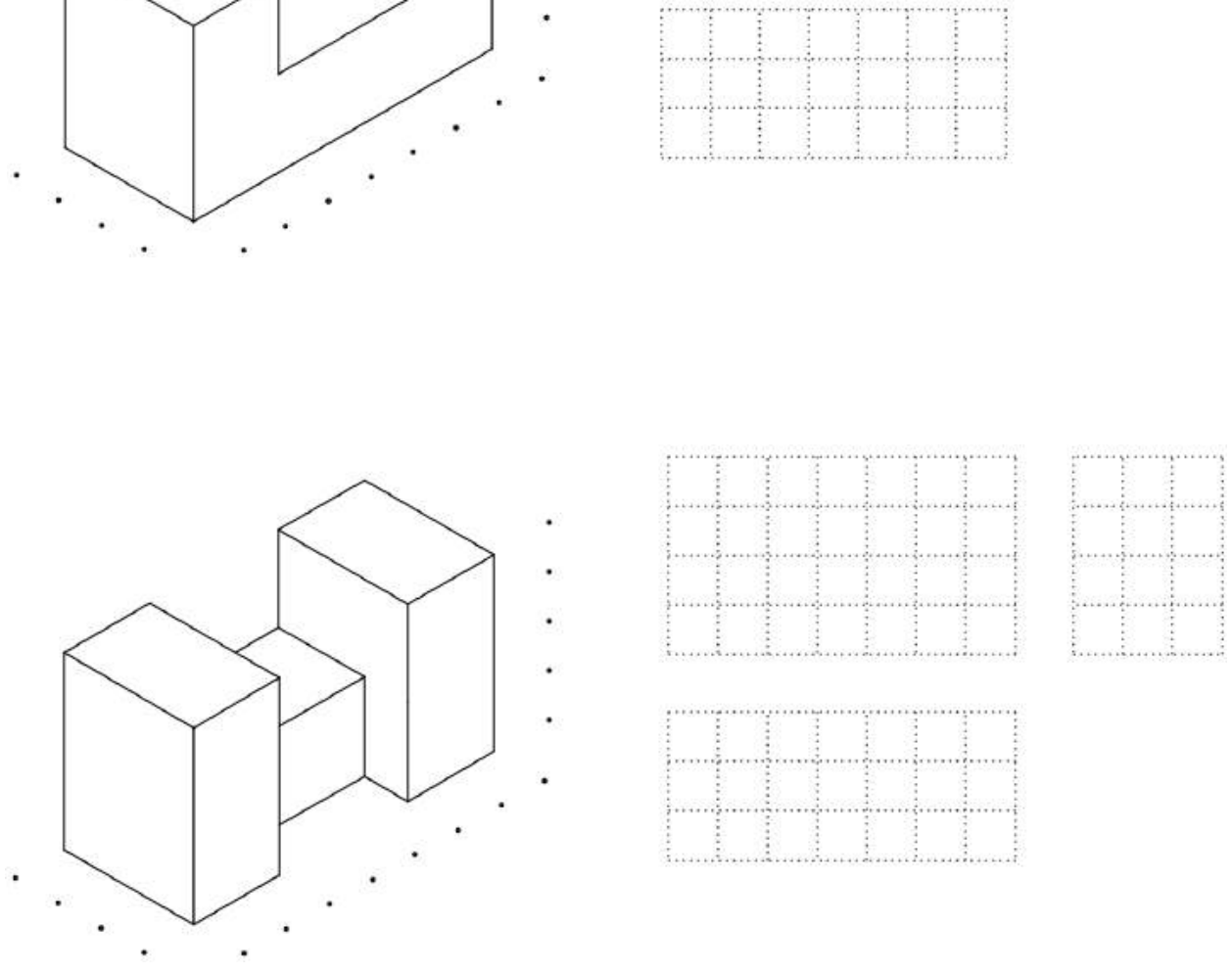
d)
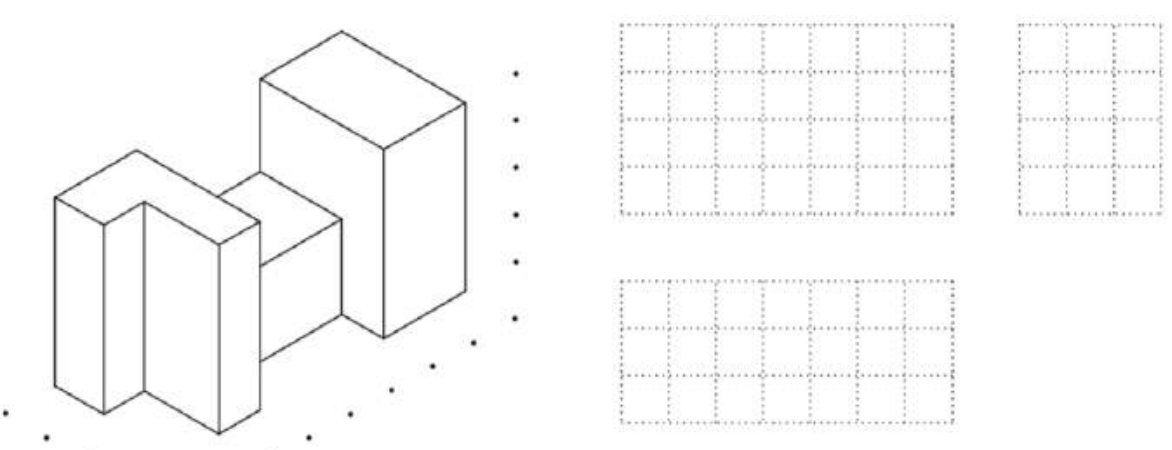

d)
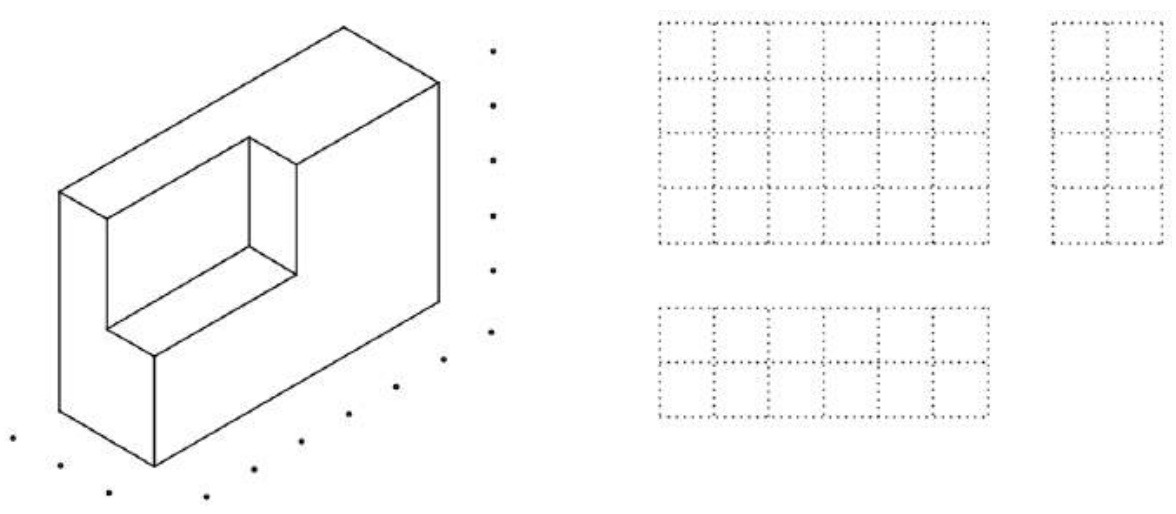

e)
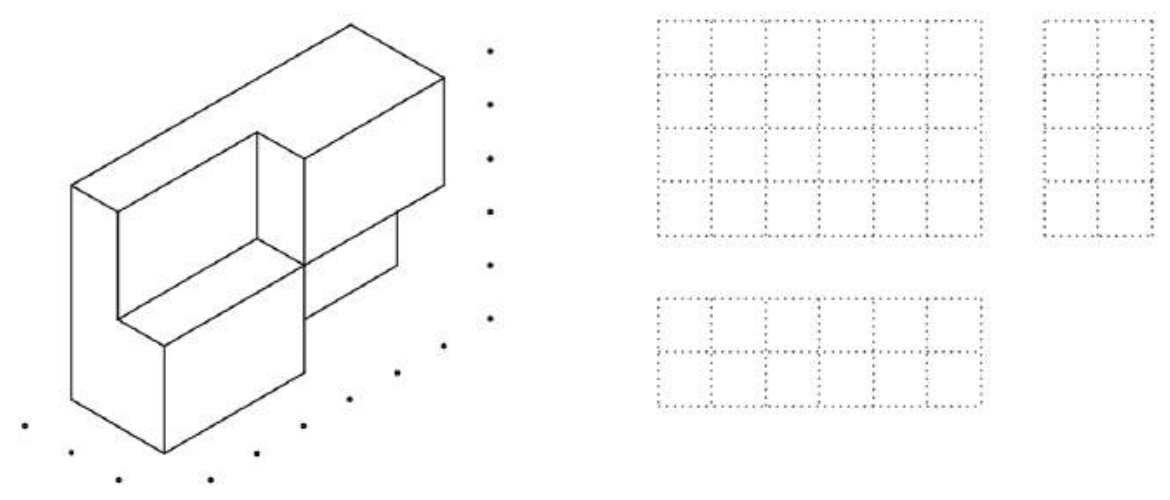

f)
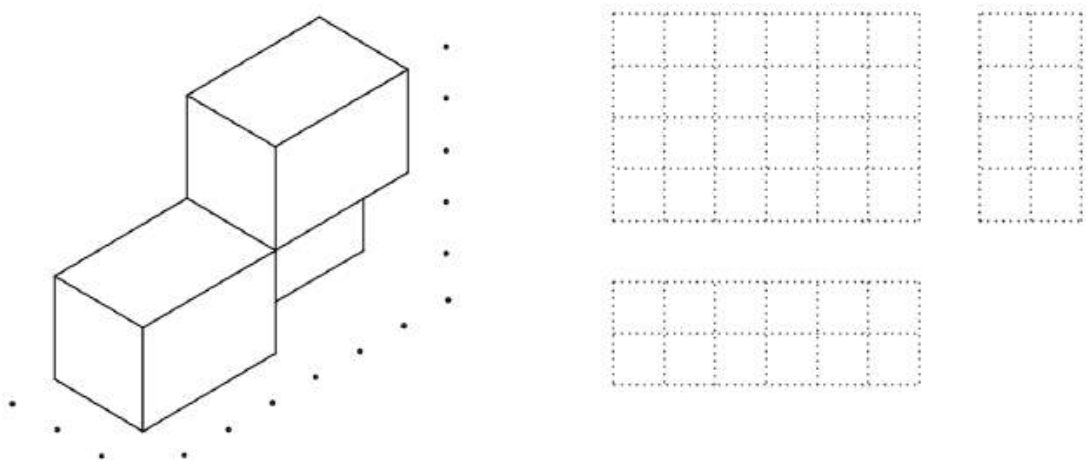
g)
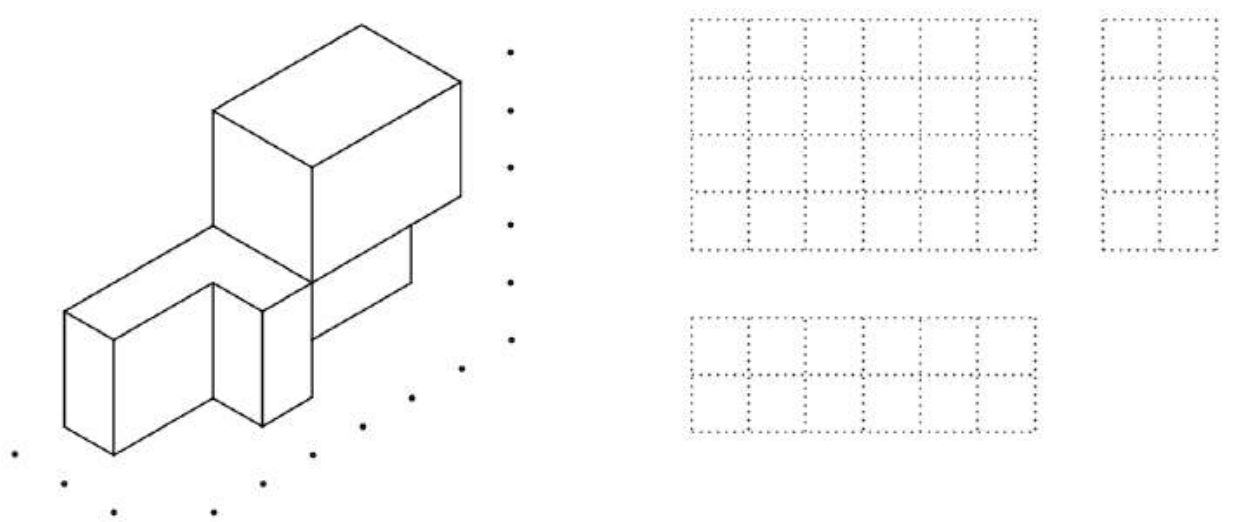

h)
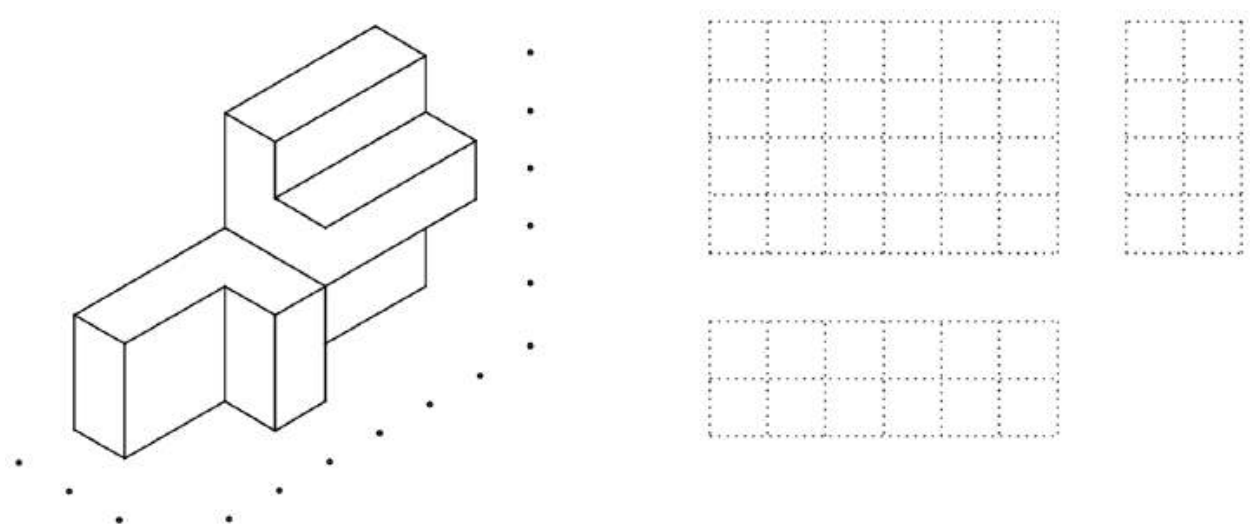

i)
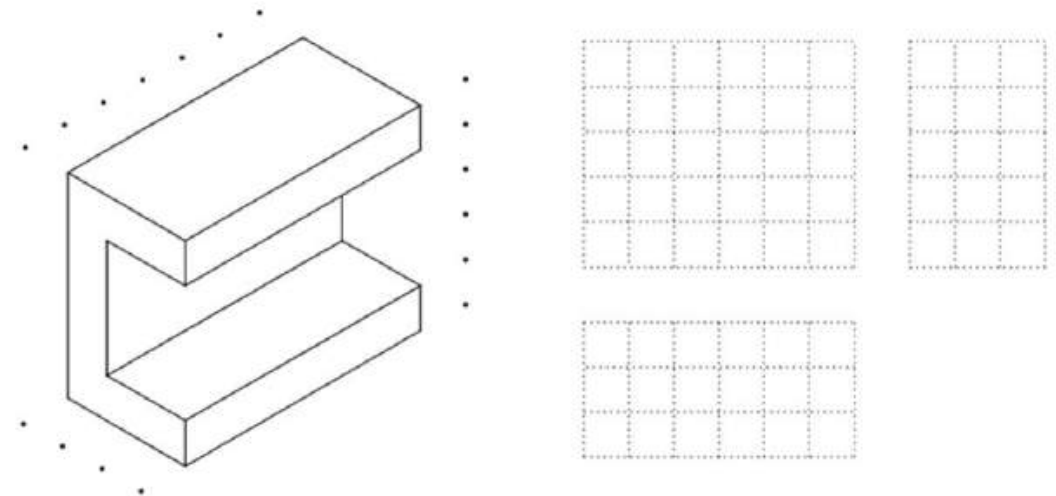

j)
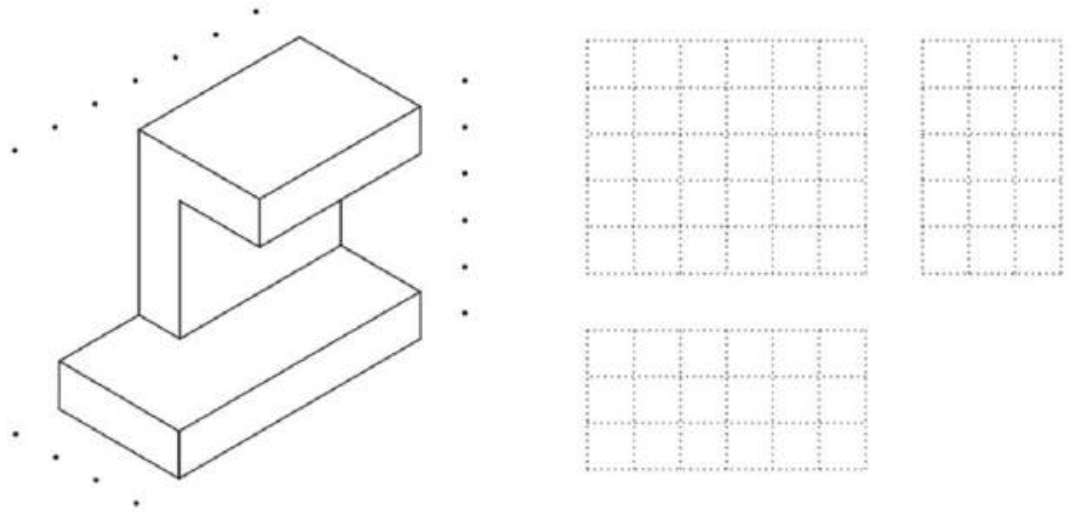
k)
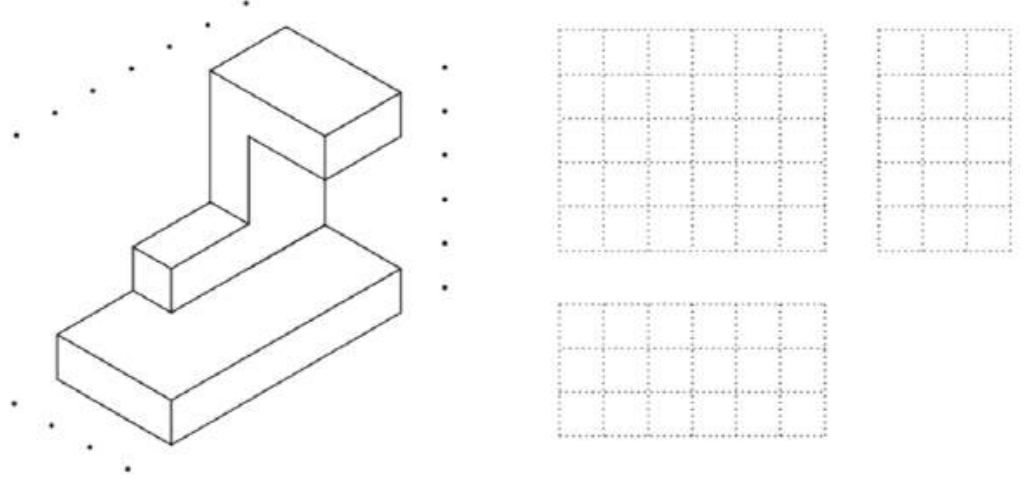

I)
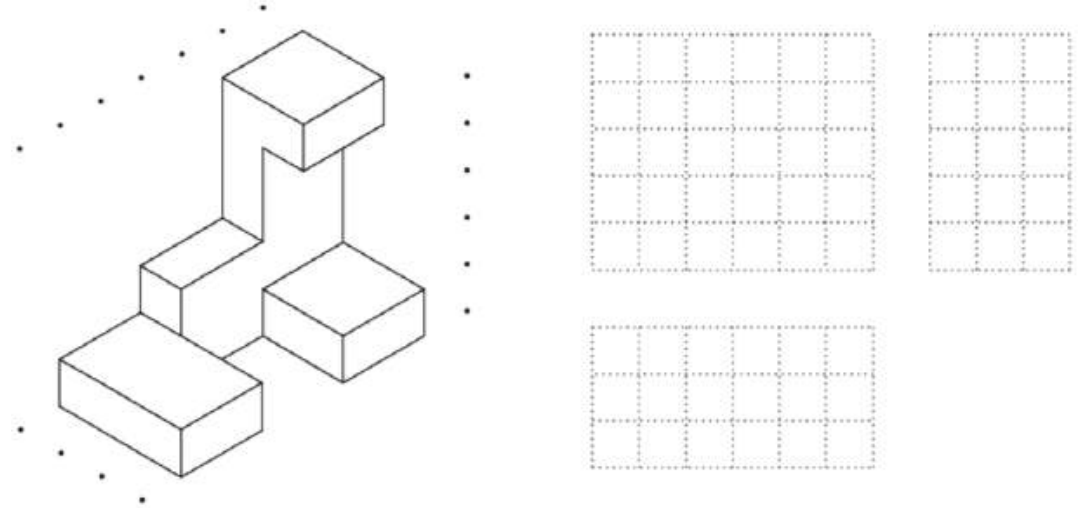

m)
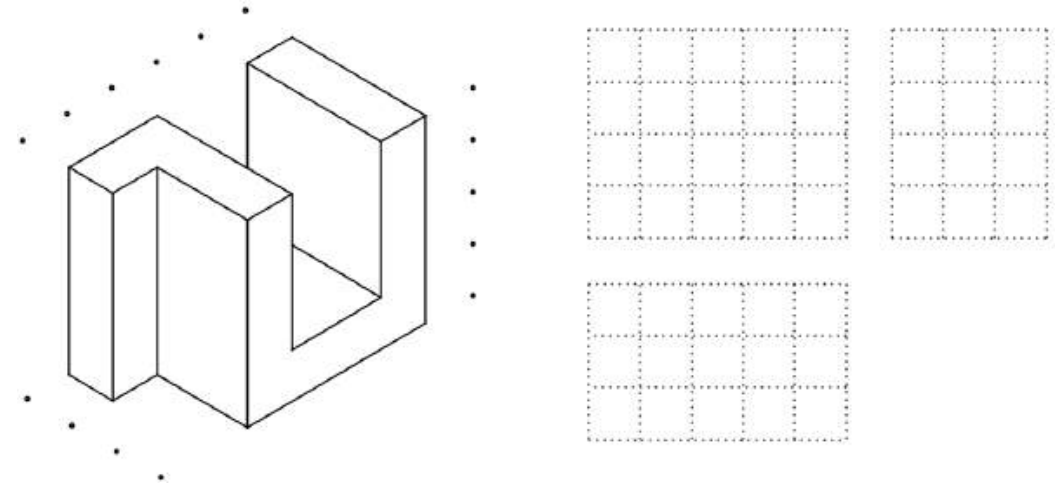

n)
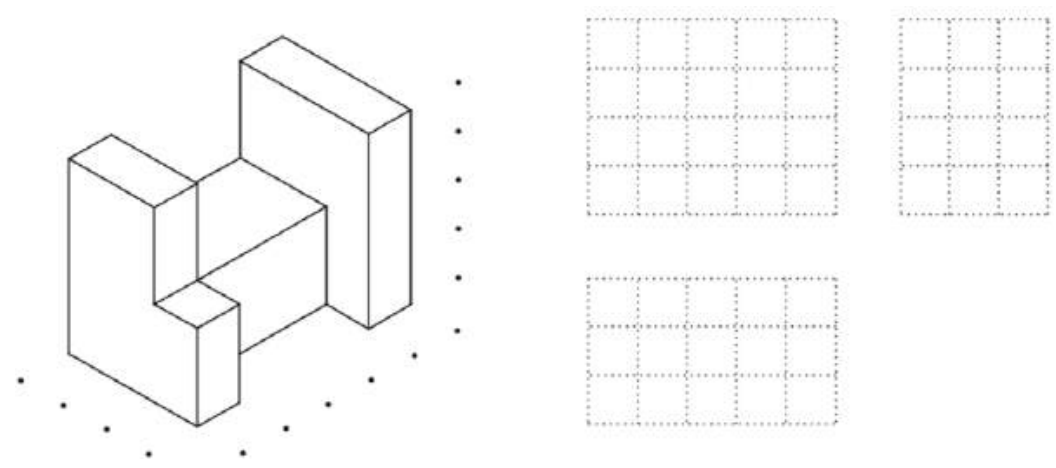
13) Desenhar as vistas ortográficas: VF, VS e VLD.

a)
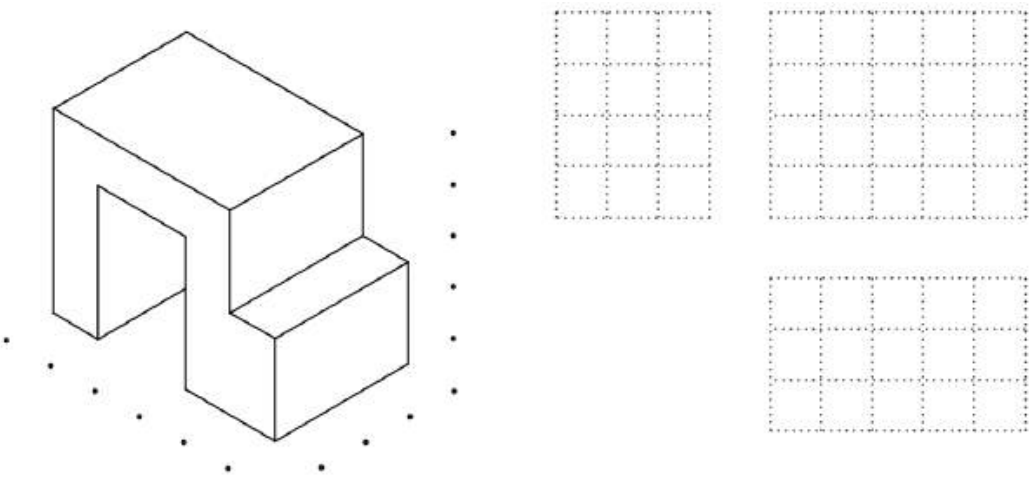

b)
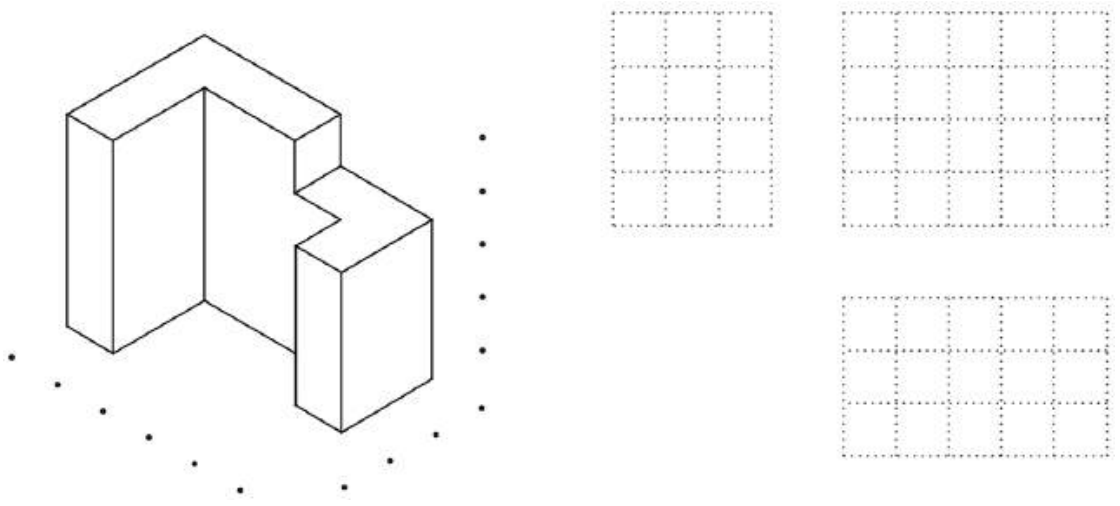

c)
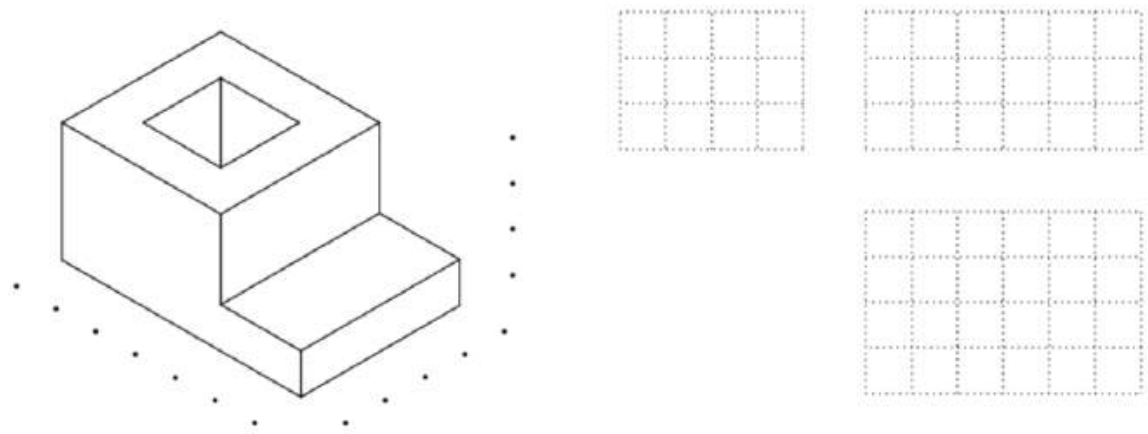

d)
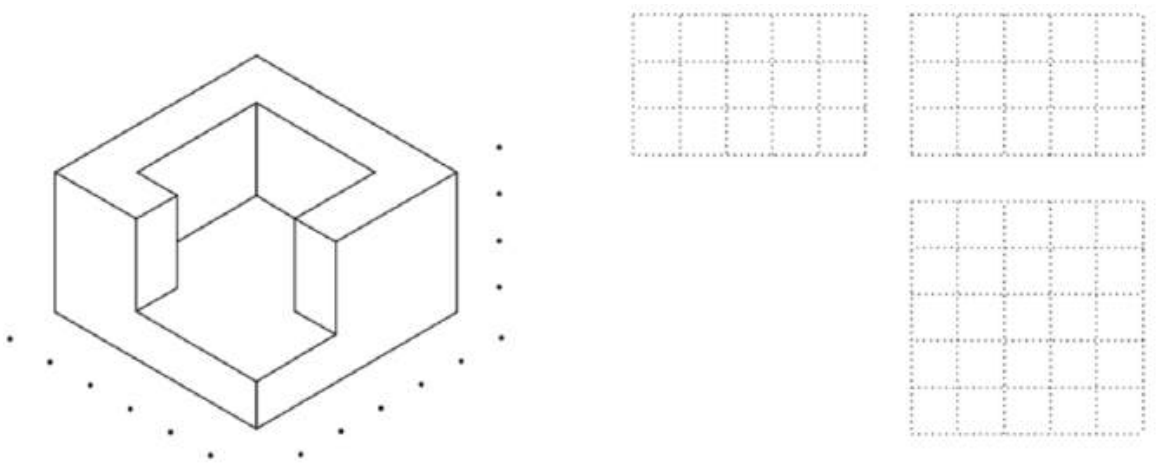
14) Analisando as projeções, completar o que falta nas vistas ortográficas.

a)
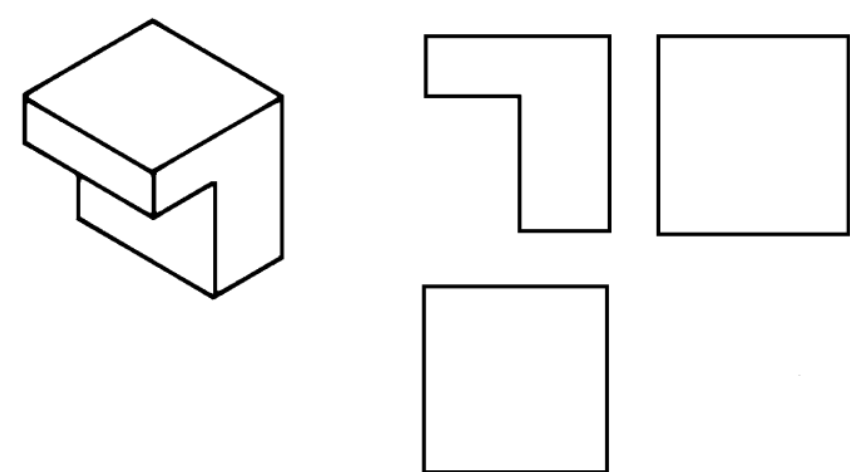

b) \}
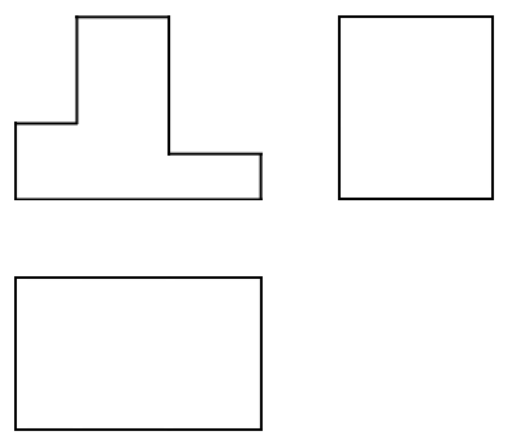

e)
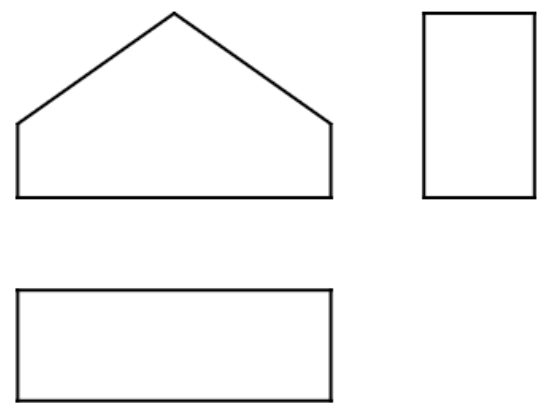

f)
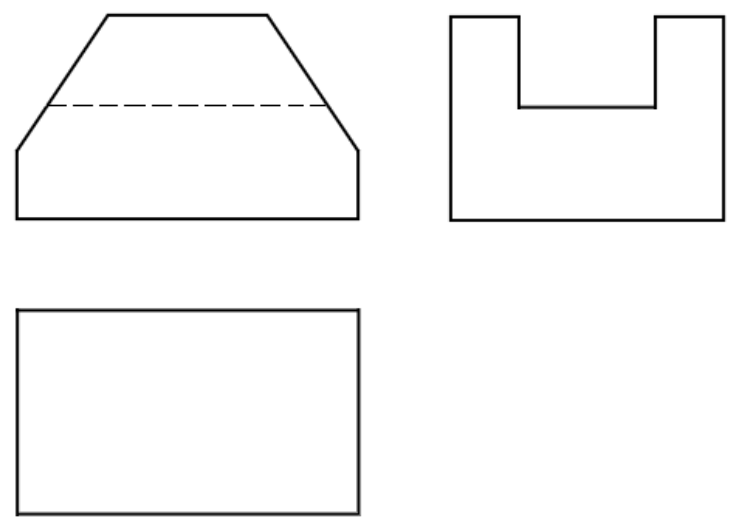
15) Desenhar mais uma vista de cada objeto.
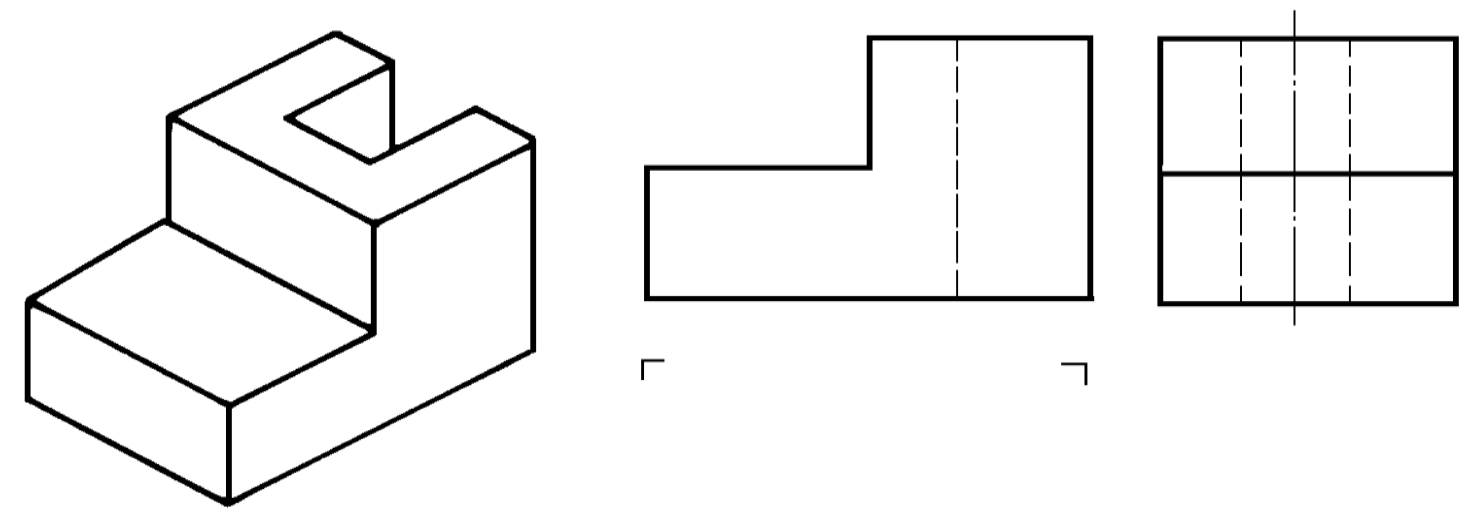

ட

\lrcorner
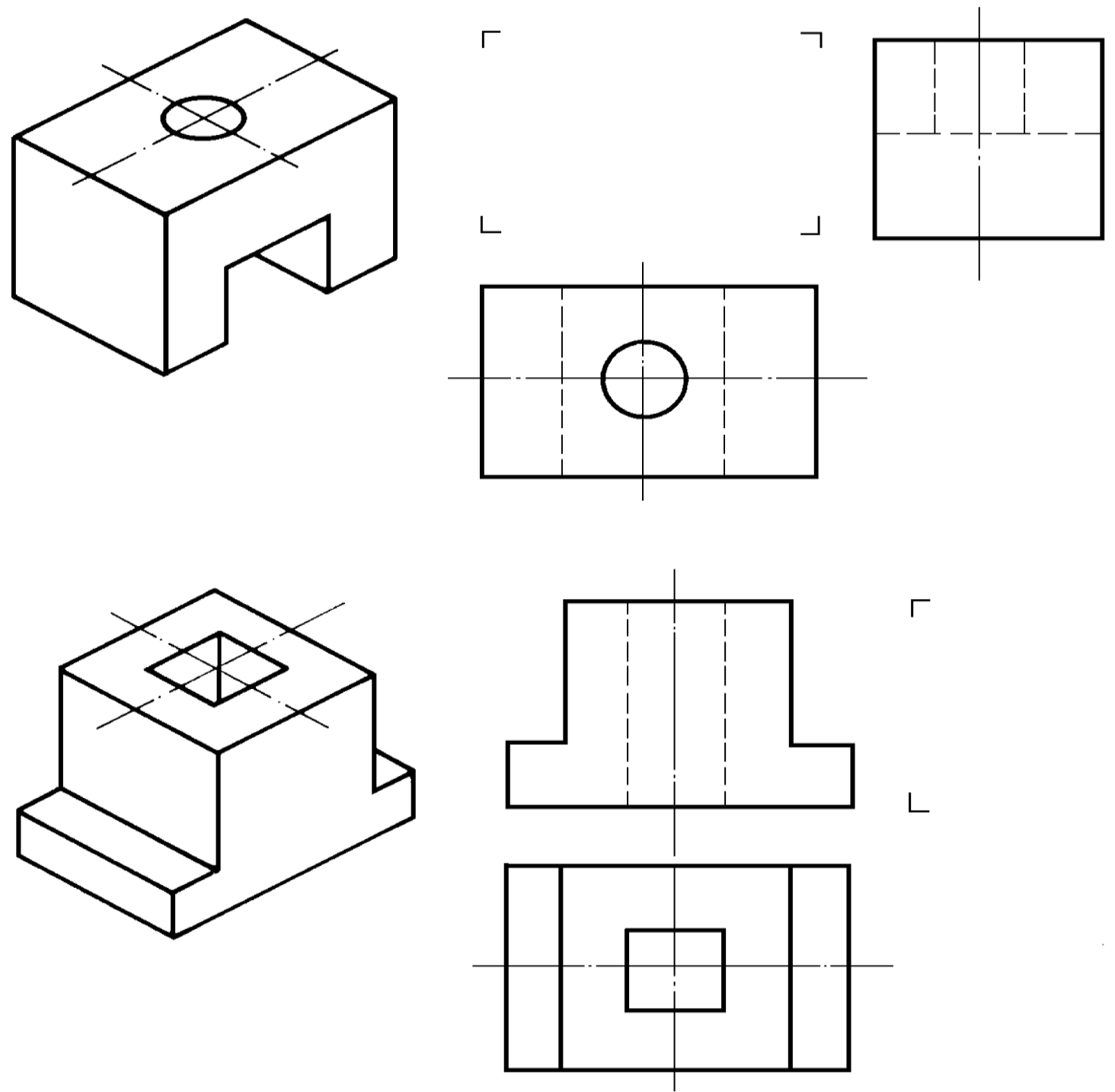

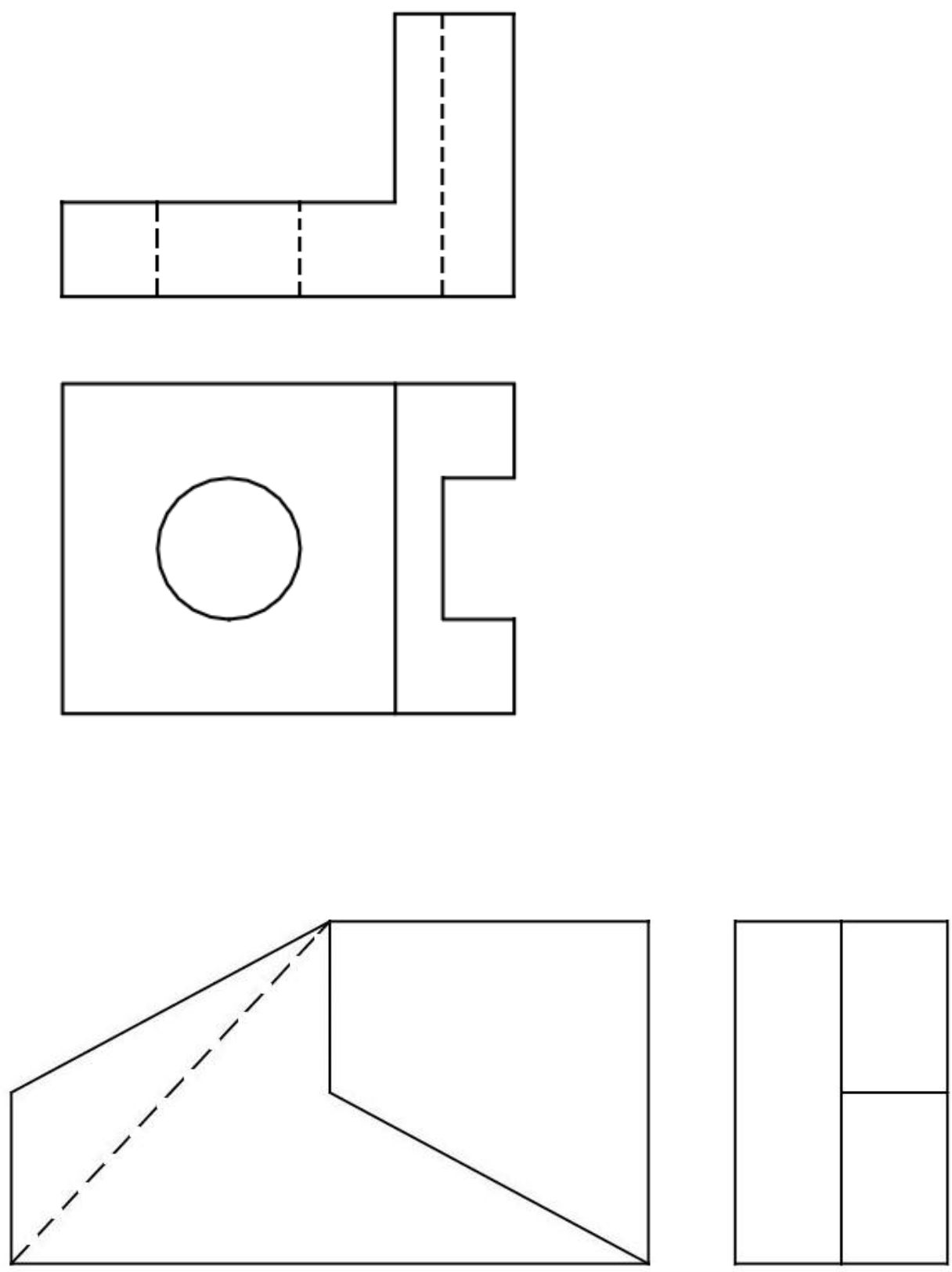
16) Desenhar as vistas ortográficas: VF, VS e VLE.

a)
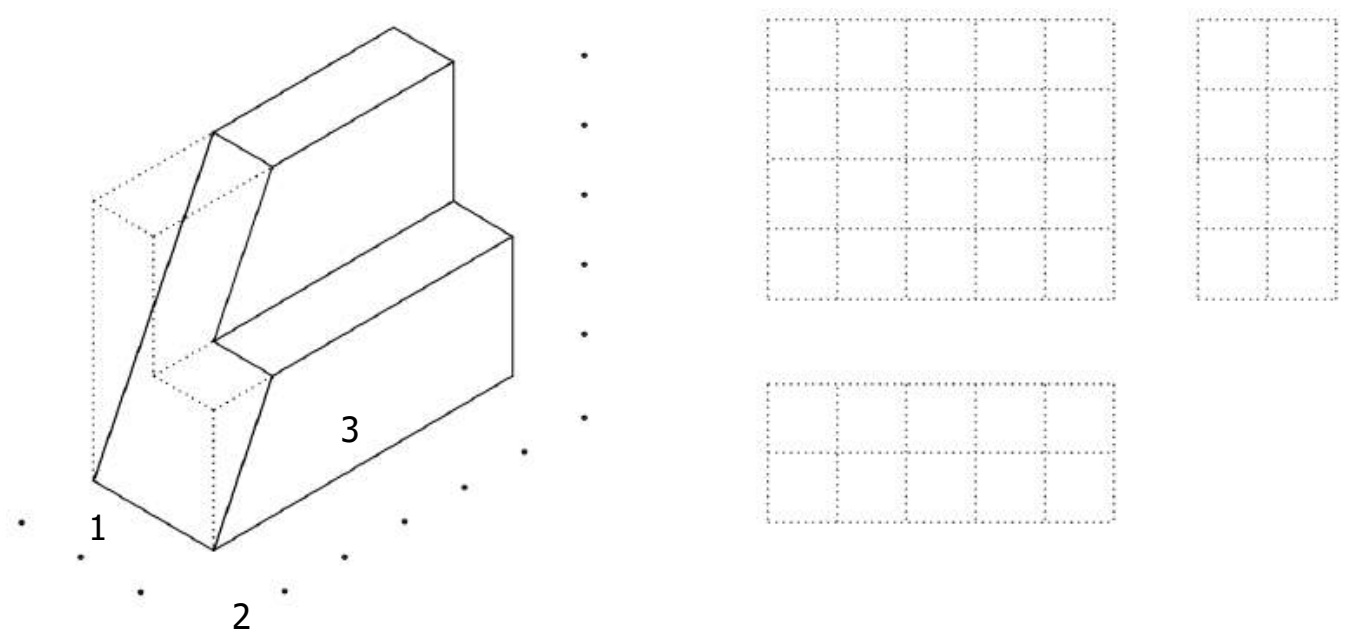

b)
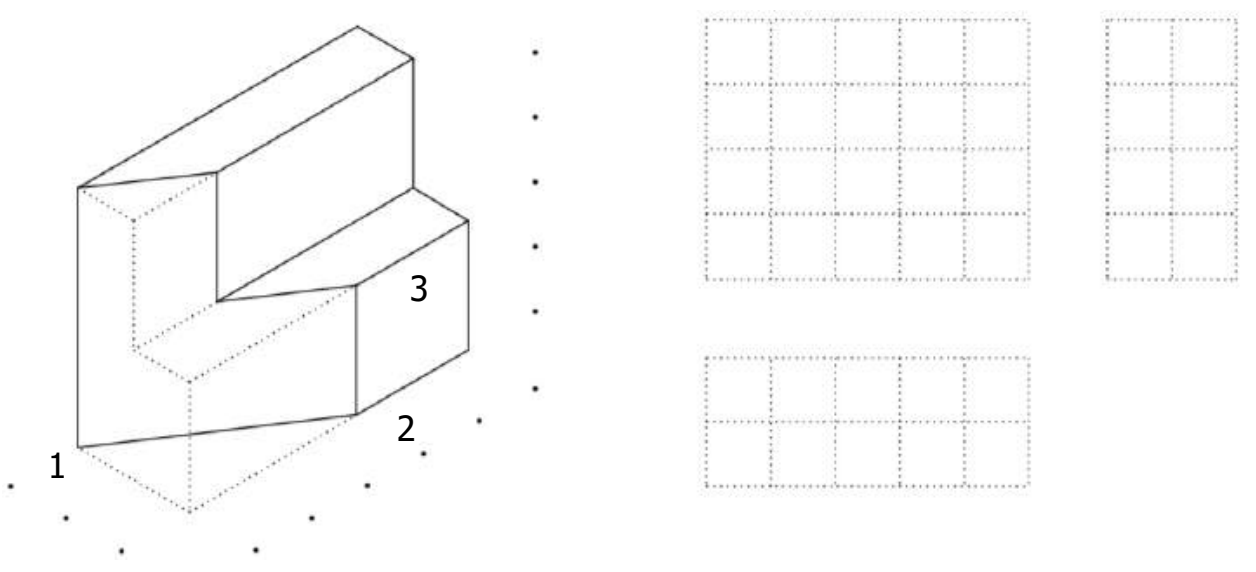


\section{CAPÍTULO 7}

\section{COTAGEM EM DESENHO TÉCNICO - NBR 10126}

A NBR 10126 (ABNT, 1987 - Versão Corrigida: 1998) tem como objetivo fixar os princípios gerais de cotagem, através de linhas, símbolos, notas e valor numérico numa unidade de medida.

As recomendações na aplicação de cotas são:

- Cotagem completa para descrever de forma clara e concisa o objeto;

- Desenhos de detalhes devem usar a mesma unidade para todas as cotas sem o emprego do símbolo;

- Evitar a duplicação de cotas, cotar o estritamente necessário;

- Sempre que possível evitar o cruzamento de linhas auxiliares com linhas de cotas e com linhas do desenho;

- A cotagem deve se dar na vista ou corte que represente mais claramente o elemento.

Os elementos gráficos para a representação da cota são (Figura 7.1):

- Linha de cota;

- Linha auxiliar;

- Limite da linha de cota (seta ou traço oblíquo);

- Valor numérico da cota.

Figura 7.1 - Elementos de cotagem.

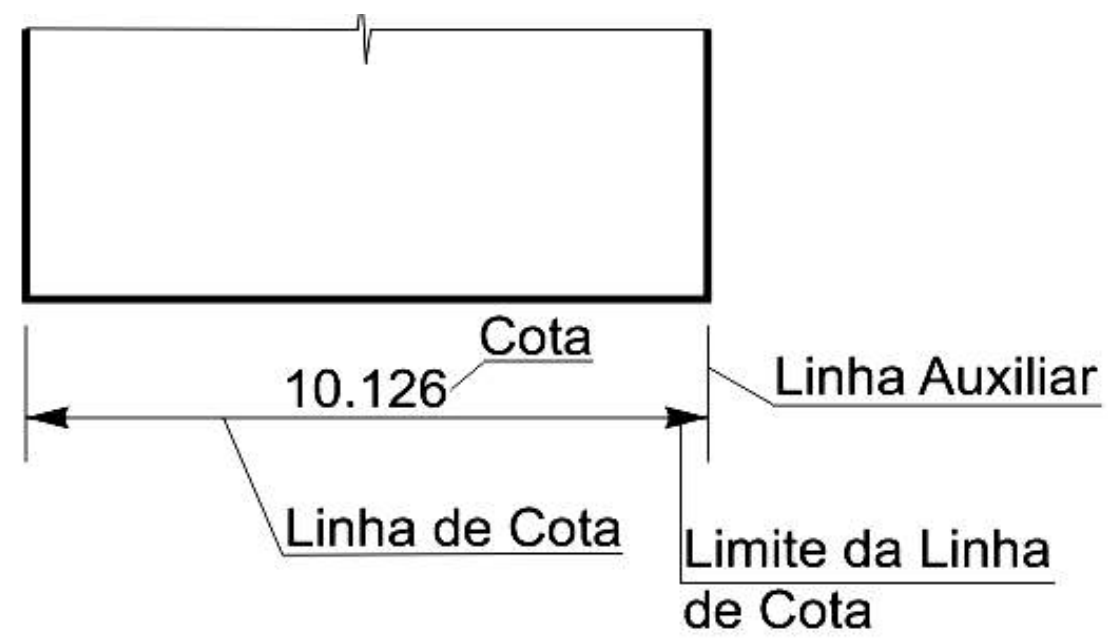


As linhas auxiliares e de cotas devem ser desenhadas como linhas estreitas contínuas. A linha auxiliar deve ser prolongada ligeiramente além da respectiva linha de cota. Um pequeno espaço deve ser deixado entre a linha de contorno e a linha auxiliar. Quando houver espaço disponível, as setas de limitação da linha de cota devem ser apresentadas entre os limites da linha de cota. Quando o espaço for limitado as setas podem ser apresentadas externamente no prolongamento da linha de cota (Figura 7.2).

Figura 7.2 - Elementos de cotagem.
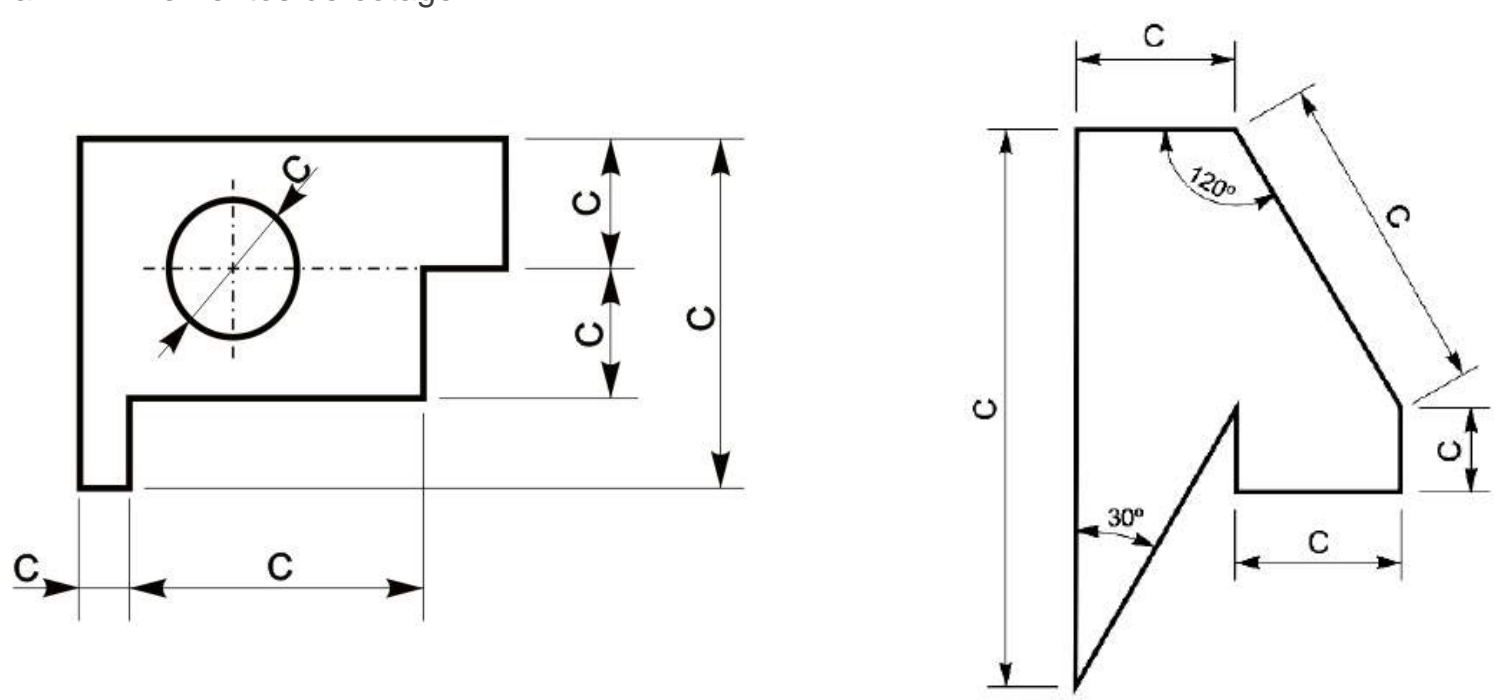

\subsection{EXEMPLOS DE COTAGEM}

A linha auxiliar deve ser perpendicular ao elemento dimensionado, mas se necessário poderá ser desenhada obliquamente a este (aprox. 60), porém paralelas entre si.

Figura 7.3 - Linha auxiliar oblíqua ao elemento dimensionado.

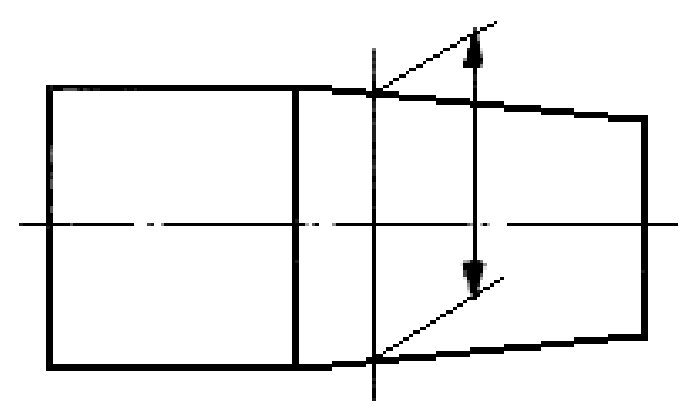

Fonte: NBR 10126 (ABNT, 1987) 
A linha de cota não deve ser interrompida, mesmo que o elemento o seja.

Figura 7.4 - Cotagem em elemento interrompido.

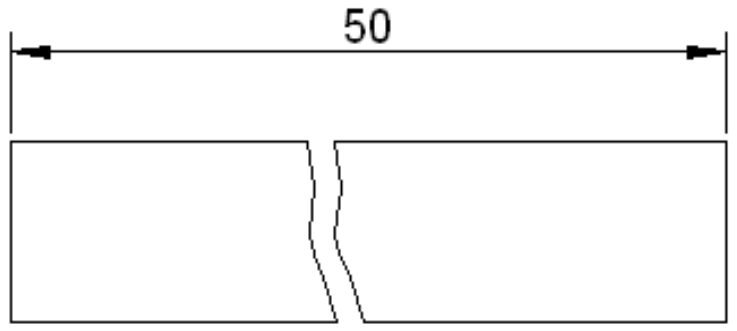

A indicação dos limites da linha de cota é feita por meio de setas ou traços oblíquos. Somente uma indicação deve ser usada num mesmo desenho, entretanto, se o espaço for pequeno, outra forma pode ser utilizada. As indicações são as seguintes:

- a seta é desenha com linhas curtas formando ângulos de $15^{\circ}$. A seta pode ser aberta, ou fechada preenchida;

- o traço oblíquo é desenhado com uma linha curta e inclinado a $45^{\circ}$.

Figura 7.5 - Indicações dos limites de linha de cota.

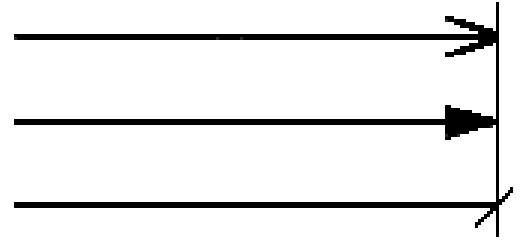

Eixos, linhas de centro, arestas e contornos de objetos não devem ser usados como linha de cota (exceção aos desenhos esquemáticos).

Figura 7.6 - Cotagem de diâmetro de circunferência.

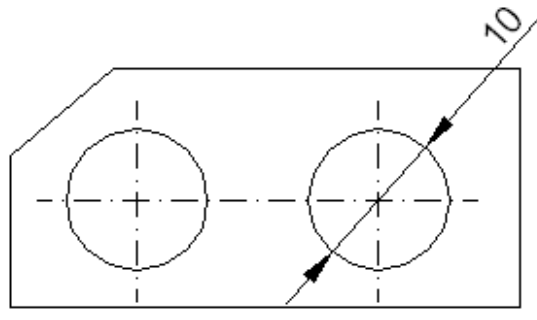

Correto

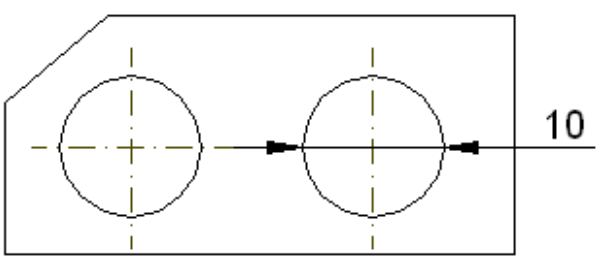

Errado 
As cotas de cordas, arcos e ângulos devem ser como mostra a Figura 7.7.

Figura 7.7 - Cotagem de cordas, arcos e ângulos.

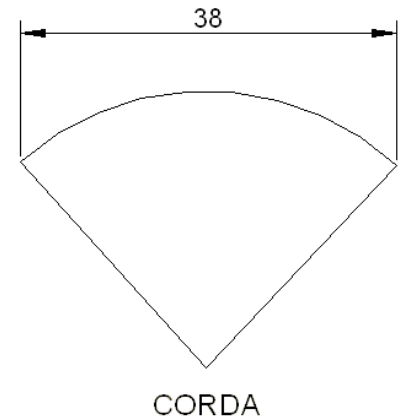

CORDA

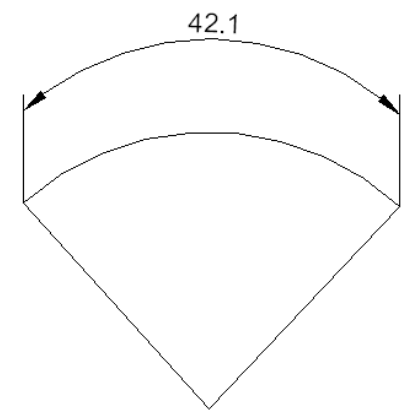

ARCO

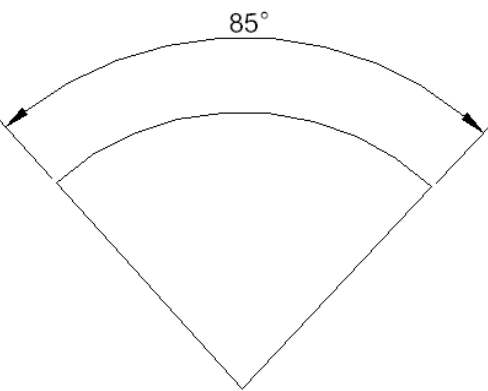

ÂNGULO

Em grandes raios, onde o centro esteja fora dos limites disponíveis para cotagem, a linha de cota deve ser quebrada.

Figura 7.8 - Cotagem de raios de arcos de circunferência.

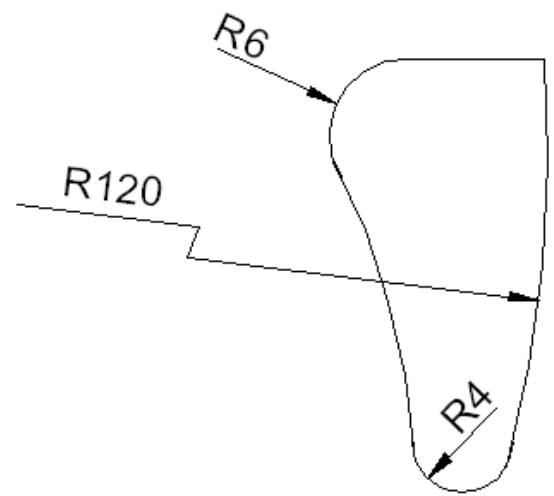

A linha de centro e a linha de contorno, não devem ser usadas como linha de cota, porém, podem ser usadas como linha auxiliar. A linha de centro, quando usada como linha auxiliar, deve continuar como linha de centro até a linha de contorno do objeto. 
Figura 7.9 - Linha de centro usada como linha auxiliar.

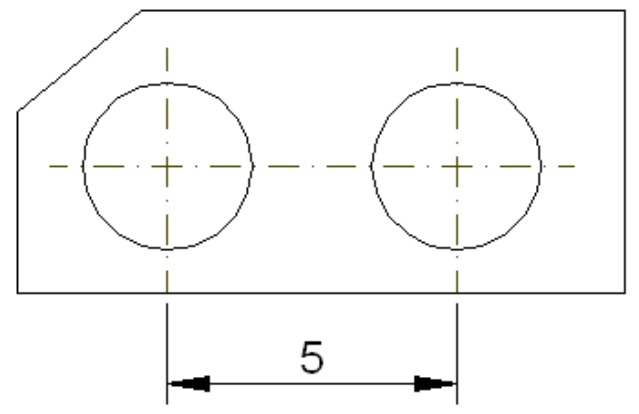

São utilizados símbolos para identificação de elementos geométricos, tais como: diâmetro $(\varnothing)$, raio $(R)$, quadrado $(\square)$. Os símbolos de diâmetro e quadrado podem ser omitidos quando a forma for claramente identificada.

As cotas devem ser localizadas de tal modo que não sejam cortadas ou separadas por qualquer outra linha.

Existem dois métodos de cotagem, mas somente um deles deve ser utilizado num mesmo desenho:

Método 1: as cotas devem ser localizadas acima e paralelamente às suas linhas de cotas e preferivelmente no centro, exceção pode ser feita onde a cotagem sobreposta é utilizada, conforme mostra a Figura a seuir. As cotas devem ser escritas de modo que possam ser lidas da base e/ou lado direito do desenho.

Figura 7.10 - Localização das cotas no método 1.
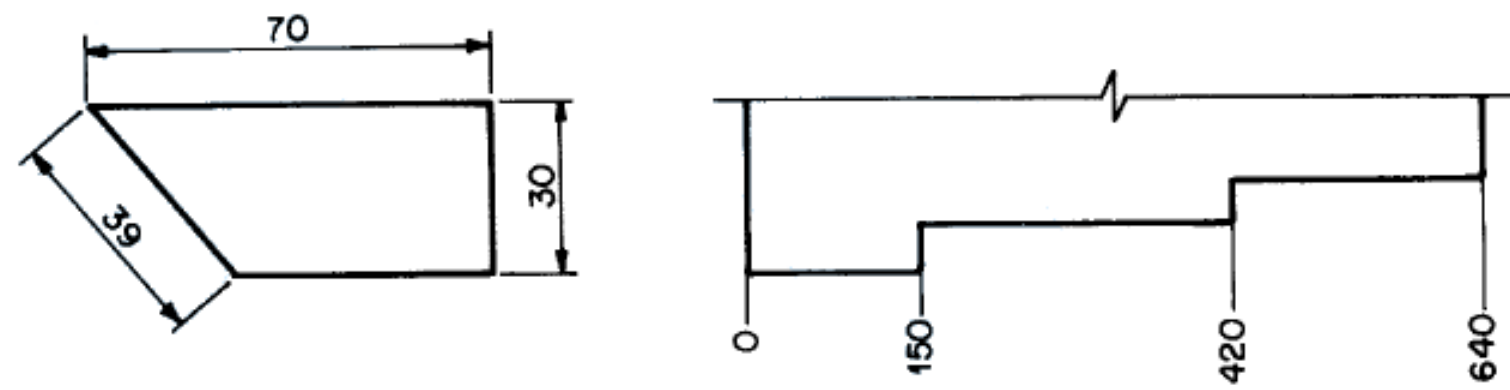

Fonte: NBR 10126 (ABNT, 1987)

Cotas em linhas de cotas inclinadas devem ser seguidas como mostra a Figura 7.11. 
Figura 7.12 - Localização das cotas em linhas de cotas inclinadas no método 1.

Fonte: NBR 10126 (ABNT, 1987)

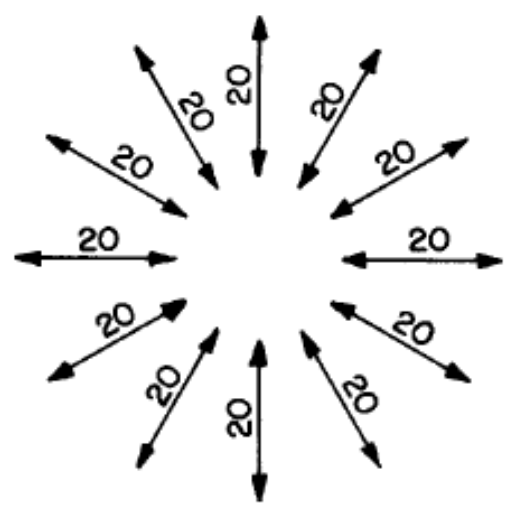

Na cotagem angular podem ser seguidas uma das formas apresentadas na figura 7.13 .

Figura 7.13 - Cotagem angular no método 1.
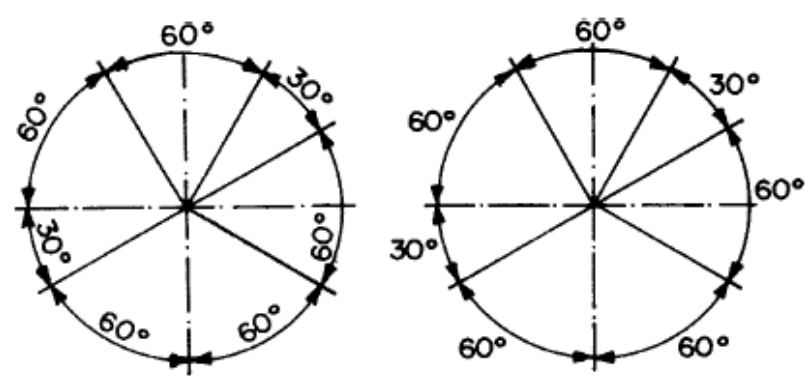

Fonte: NBR 10126 (ABNT, 1987)

Método 2: as cotas devem ser lidas da base da folha de papel. As linhas de cotas devem ser interrompidas, preferivelmente no meio, para inscrição da cota.

Figura 7.14 - Localização das cotas no método 2.
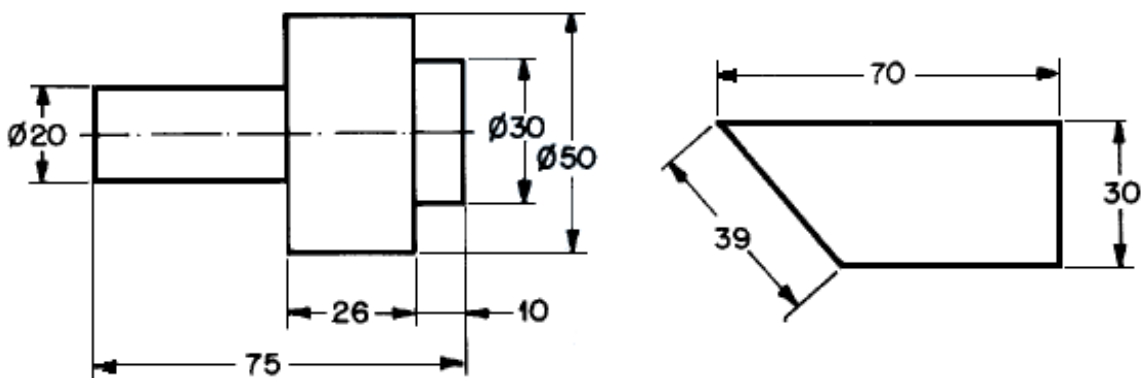

Fonte: NBR 10126 (ABNT, 1987) 
$\mathrm{Na}$ cotagem angular podem ser seguidas uma das formas apresentadas na Figura 7.15.

Figura 7.15 - Cotagem angular no método 2.
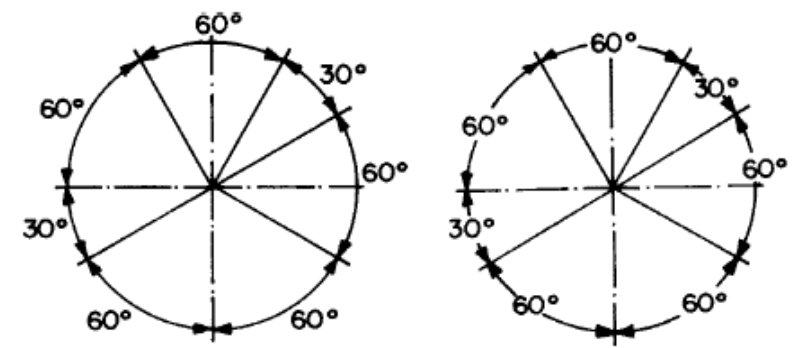

Fonte: NBR 10126 (ABNT, 1987)

Observação: Em Desenho Técnico Mecânico, o método mais utilizado é o 1 (salvo situações com cotagem de chapas metálicas). Ou seja, o que será utilizado em nossos desenhos sempre será este método mostrado abaixo. Outro método de cotagem será considerado errado em nossa disciplina.

Figura 7.16 - Cotagem Representado em Desenho Técnico Mecânico.

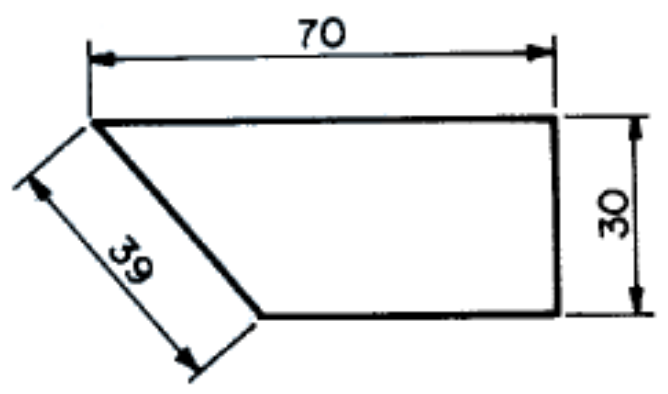

\subsection{MAIS EXEMPLOS DE COTAGEM}
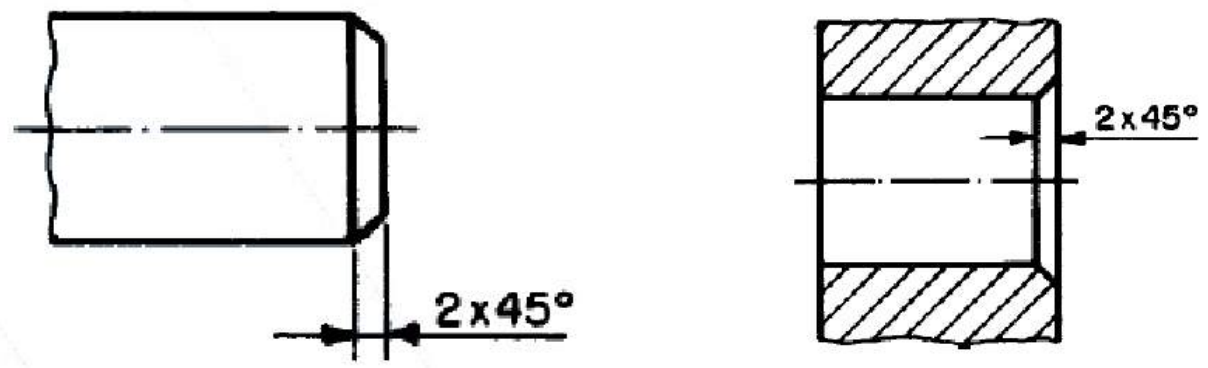

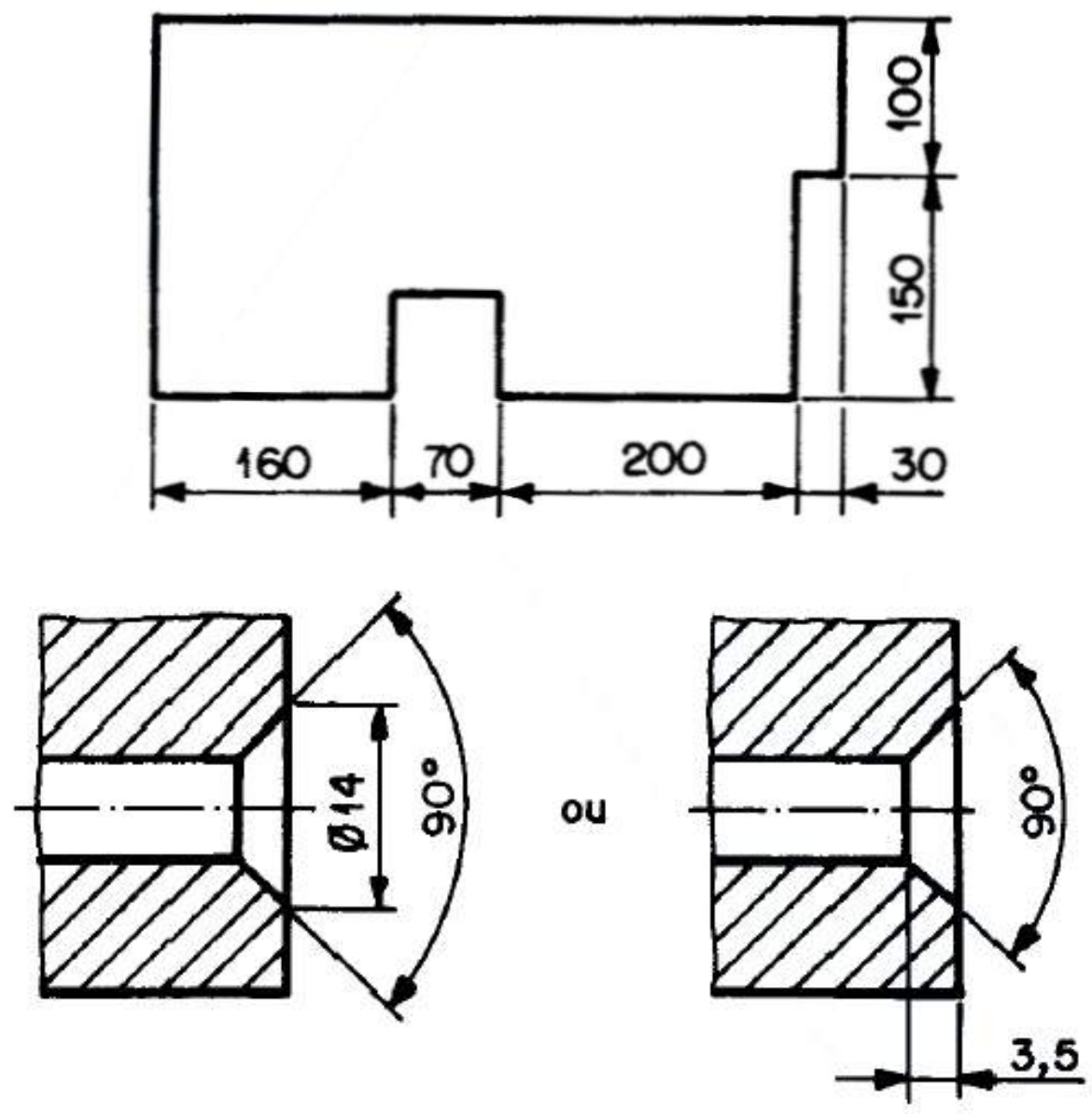

\subsection{COTAGEM EM SÉRIE}

O próprio nome já diz, utiliza-se um vértice como referência, geralmente no canto inferior esquerdo, para iniciar a cotagem e as novas cotas são inseridas a partir das cotas já existentes. Conforme mostrado na figura a seguir.

O problema é que pode gerar uma sequência de pequenos erros, somandose um erro fora do previsto no projeto.

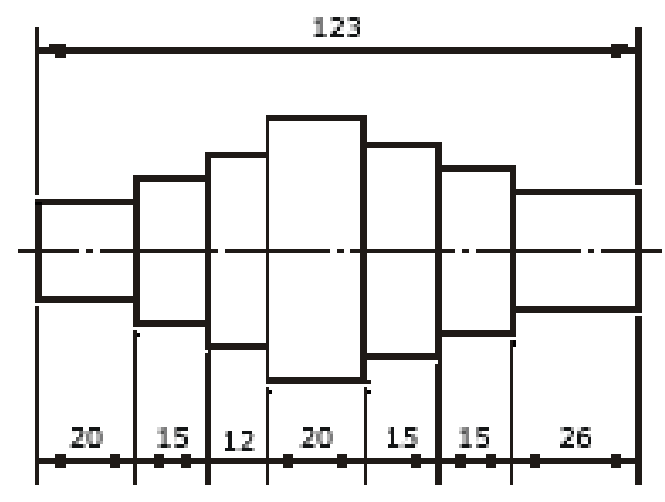

(a)

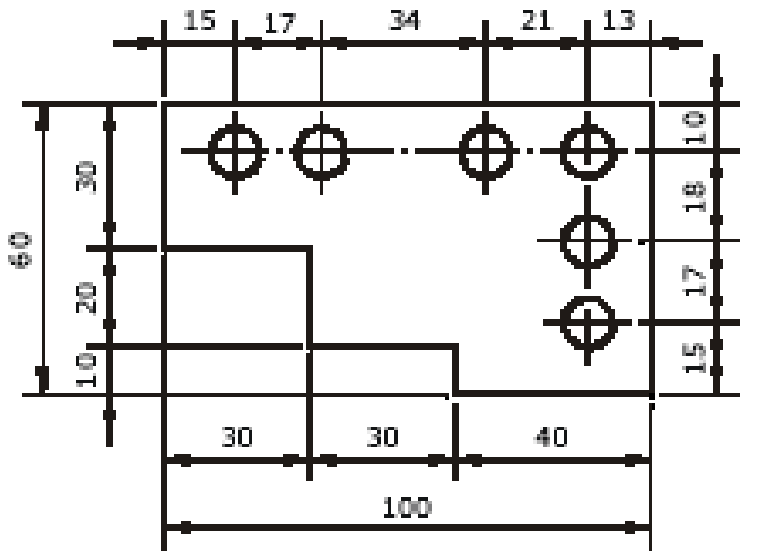

(b) 
7.4 COTAGEM UTILIZANDO FACES DE REFERÊNCIA

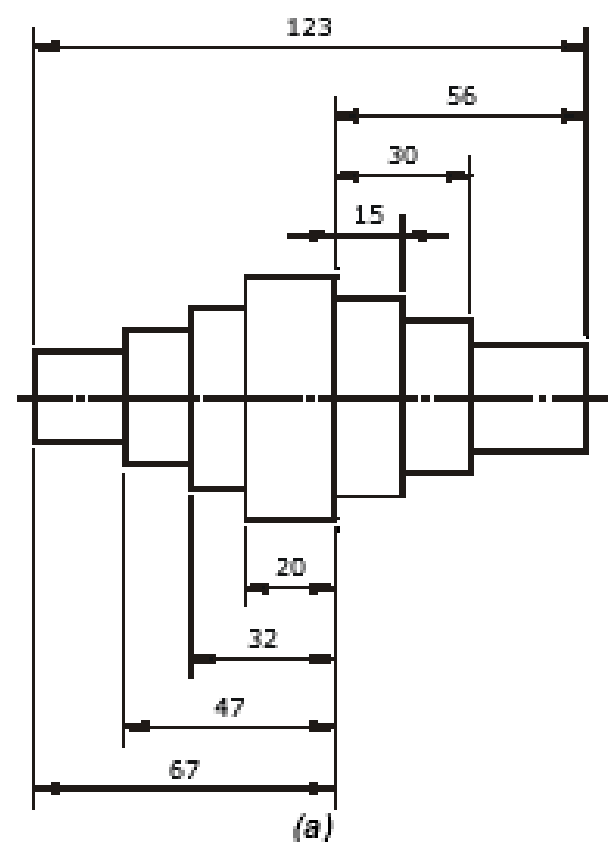

(a)

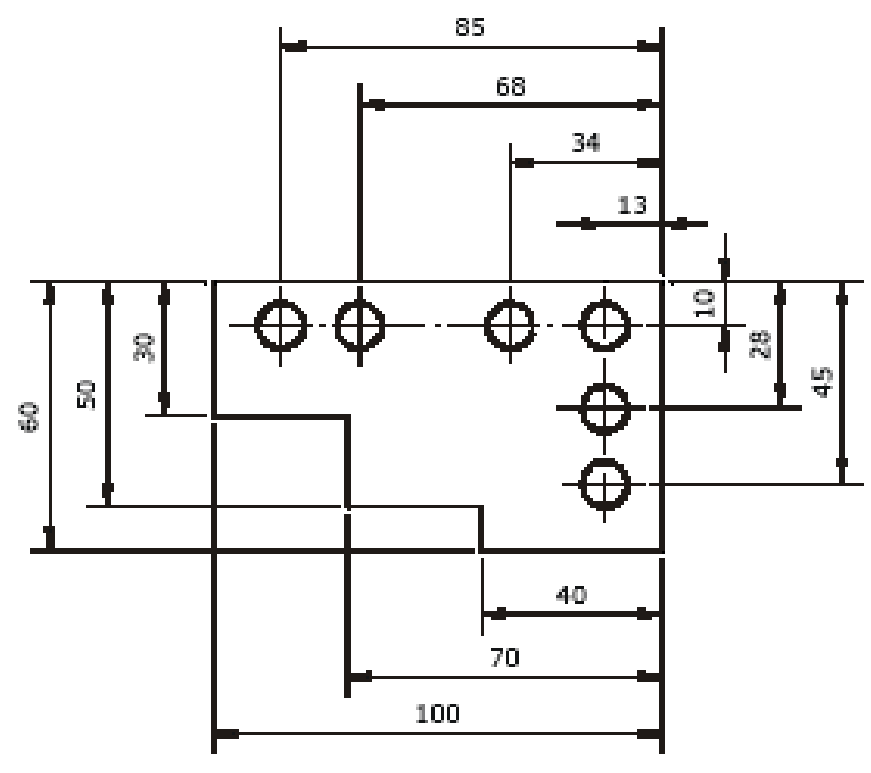

(b)

7.5 SEQÜENCIA DE COTAGEM
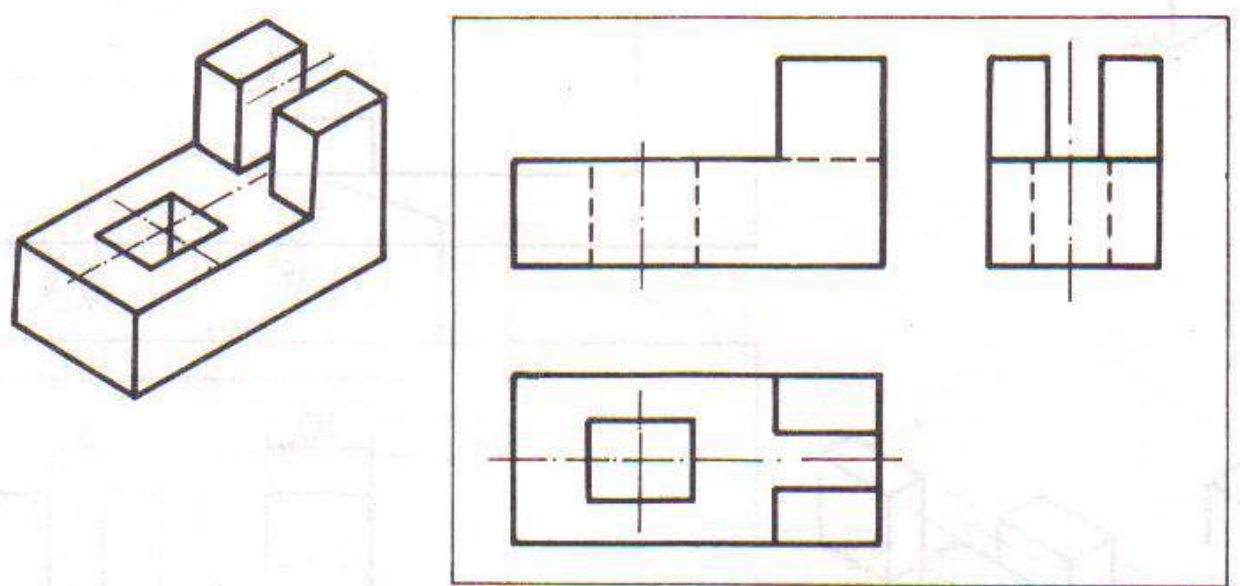

10 Passo
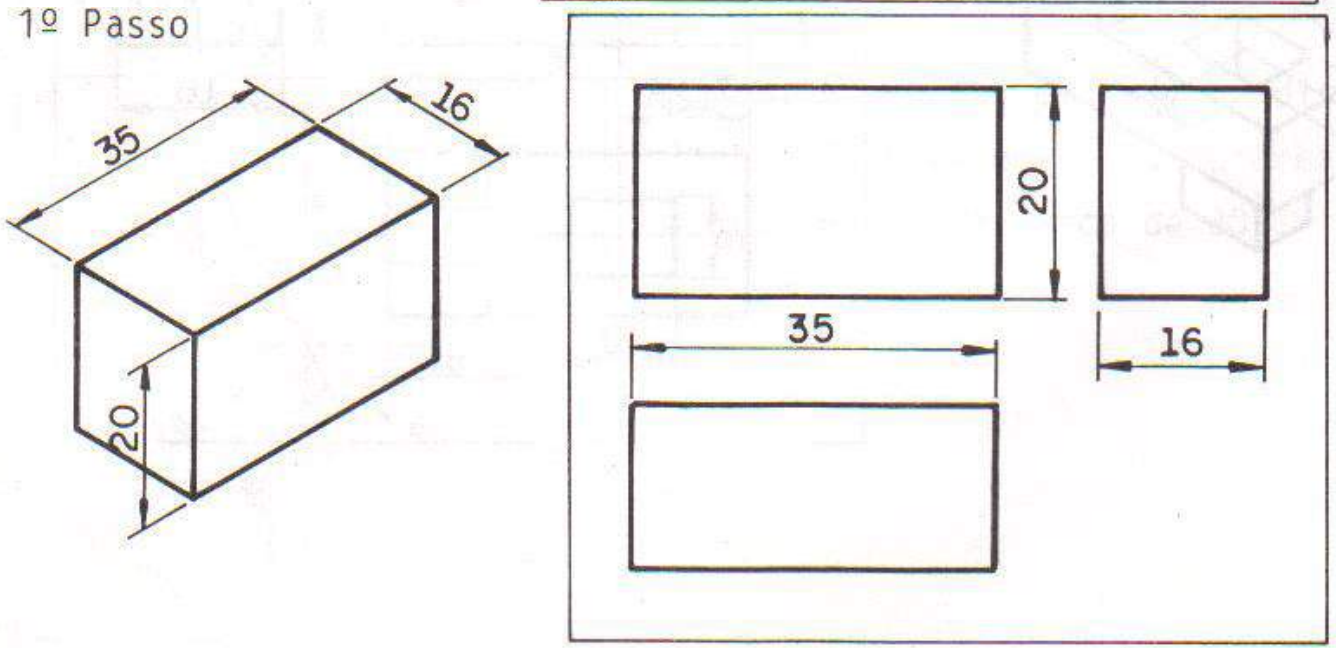

Catapan, Strobel e Santana (2020) 

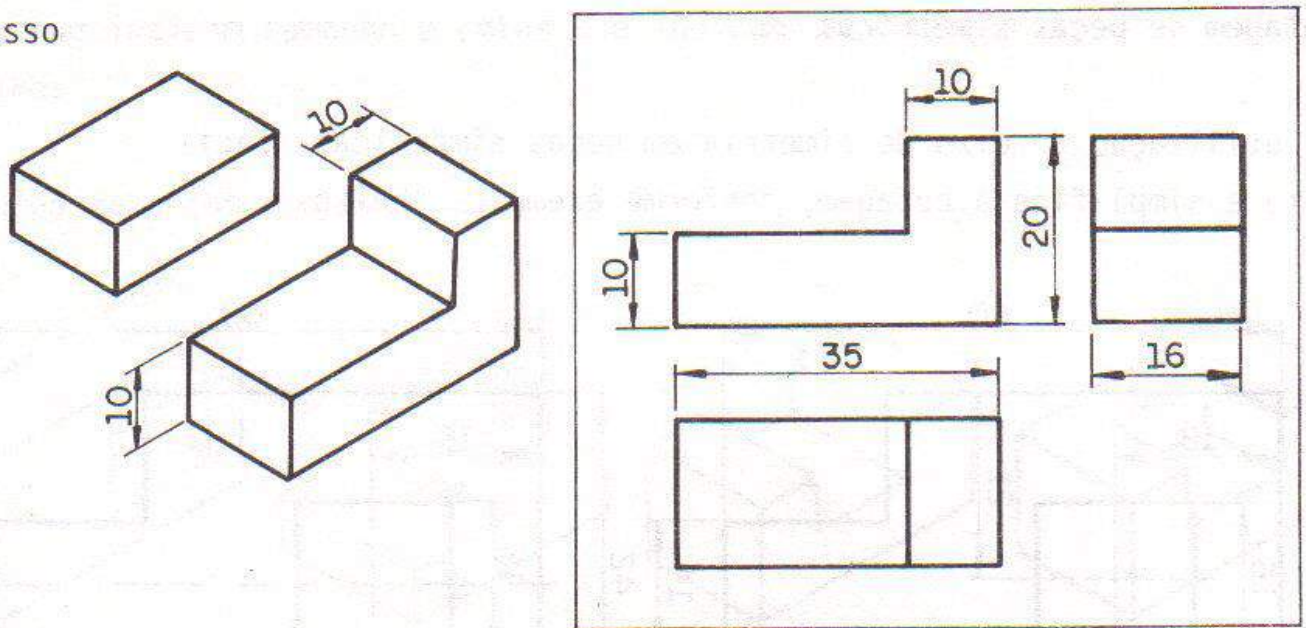

3․ Passo
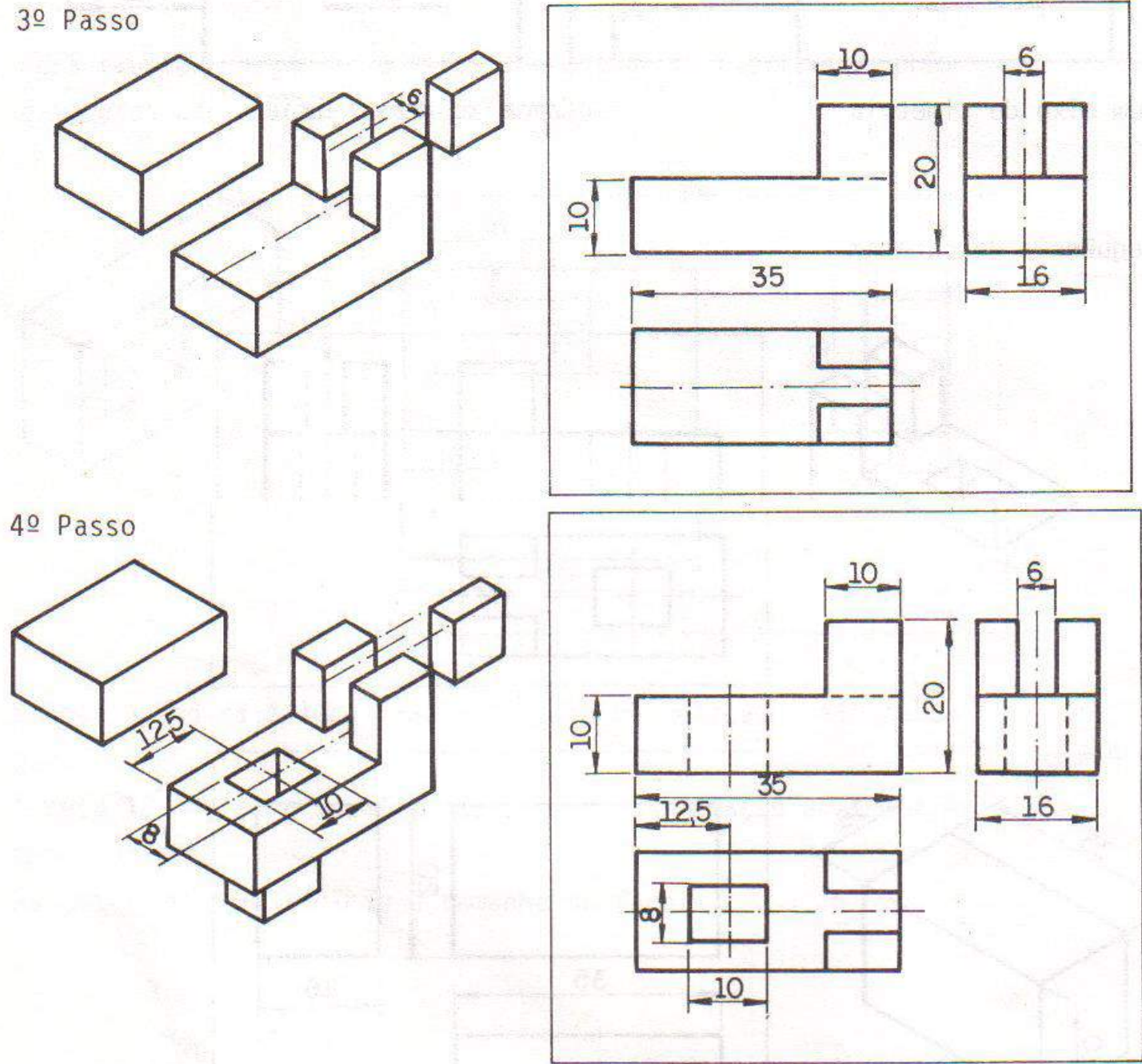

Observação: É importante salientar que sempre se deve evitar a cotagem de linhas tracejadas, ou seja, de arestas não visíveis. Nesse caso, deve ser representado em alguma projeção da vista. Conforme visto acima. 


\section{EXERCÍCIOS}

1. Analise o desenho técnico abaixo e responda às questões a seguir.

a) Escreva dentro dos parênteses as letras correspondentes a cada elemento de cotagem.

( ) Linha de cota

( ) Linha auxiliar de cota

( ) Cota

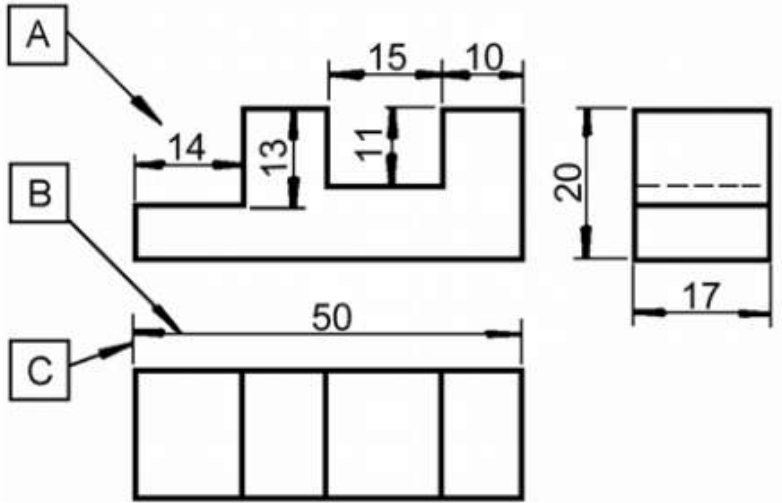

a) Escreva as cotas básicas de: comprimento: altura: largura:

b) Escreva as cotas básicas que determinam o tamanho do rasgo: e

c) Escreva a cota que determina a localização do rasgo:

d) Escreva as cotas que determinam o tamanho do rebaixo: e

2. Observe as perspectivas isométricas e escreva as cotas nas projeções ortográficas:

a)
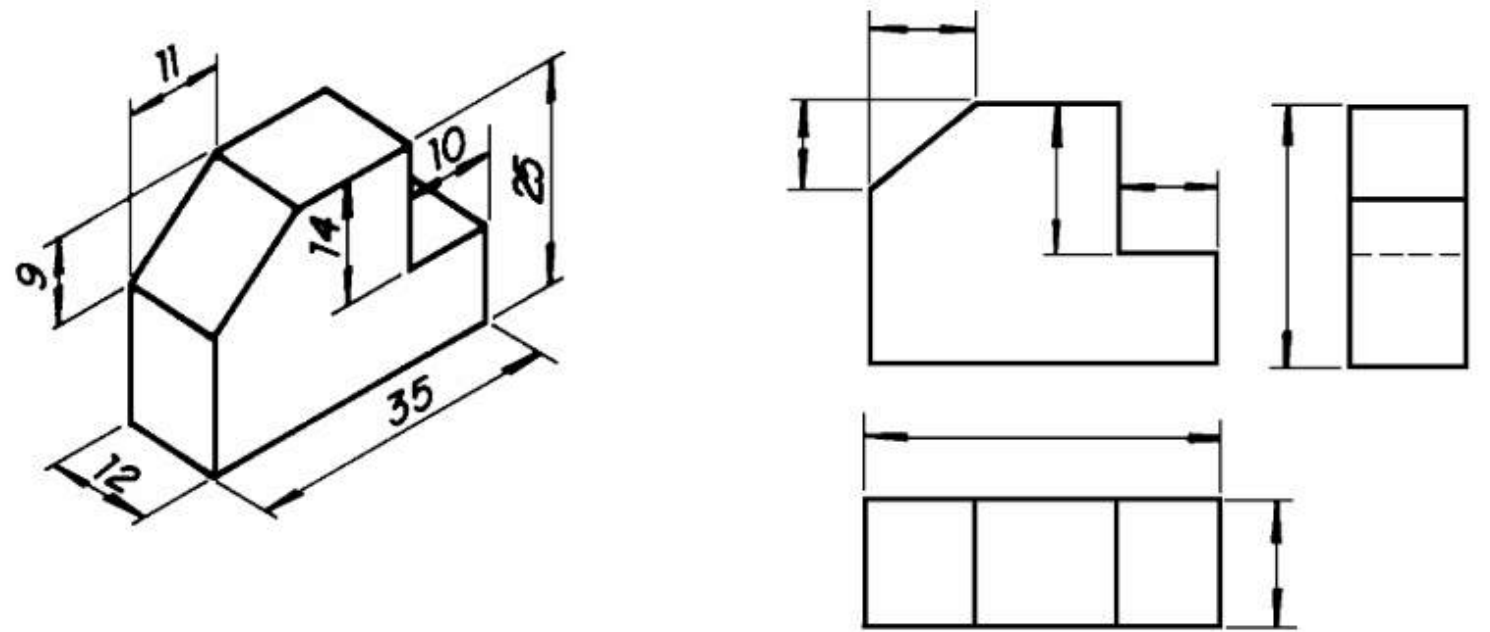
b)
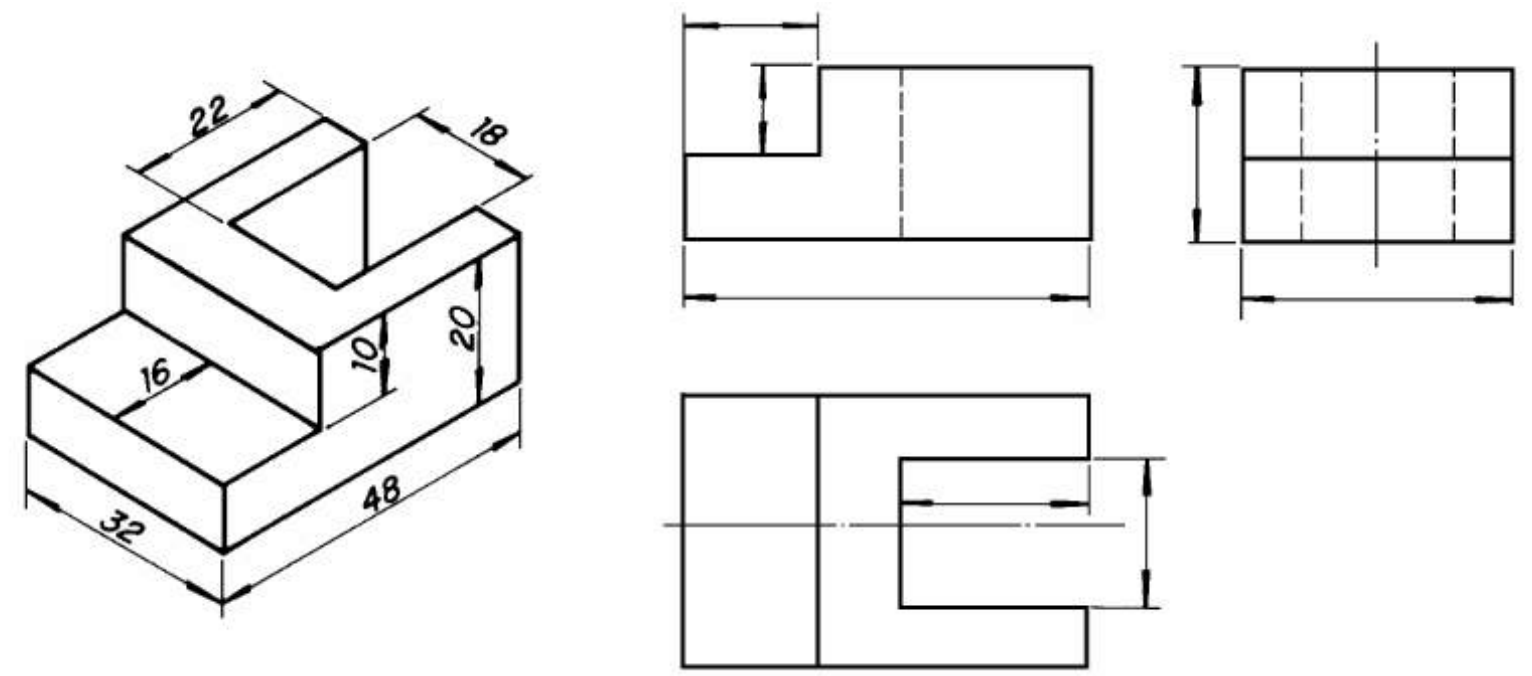

c)
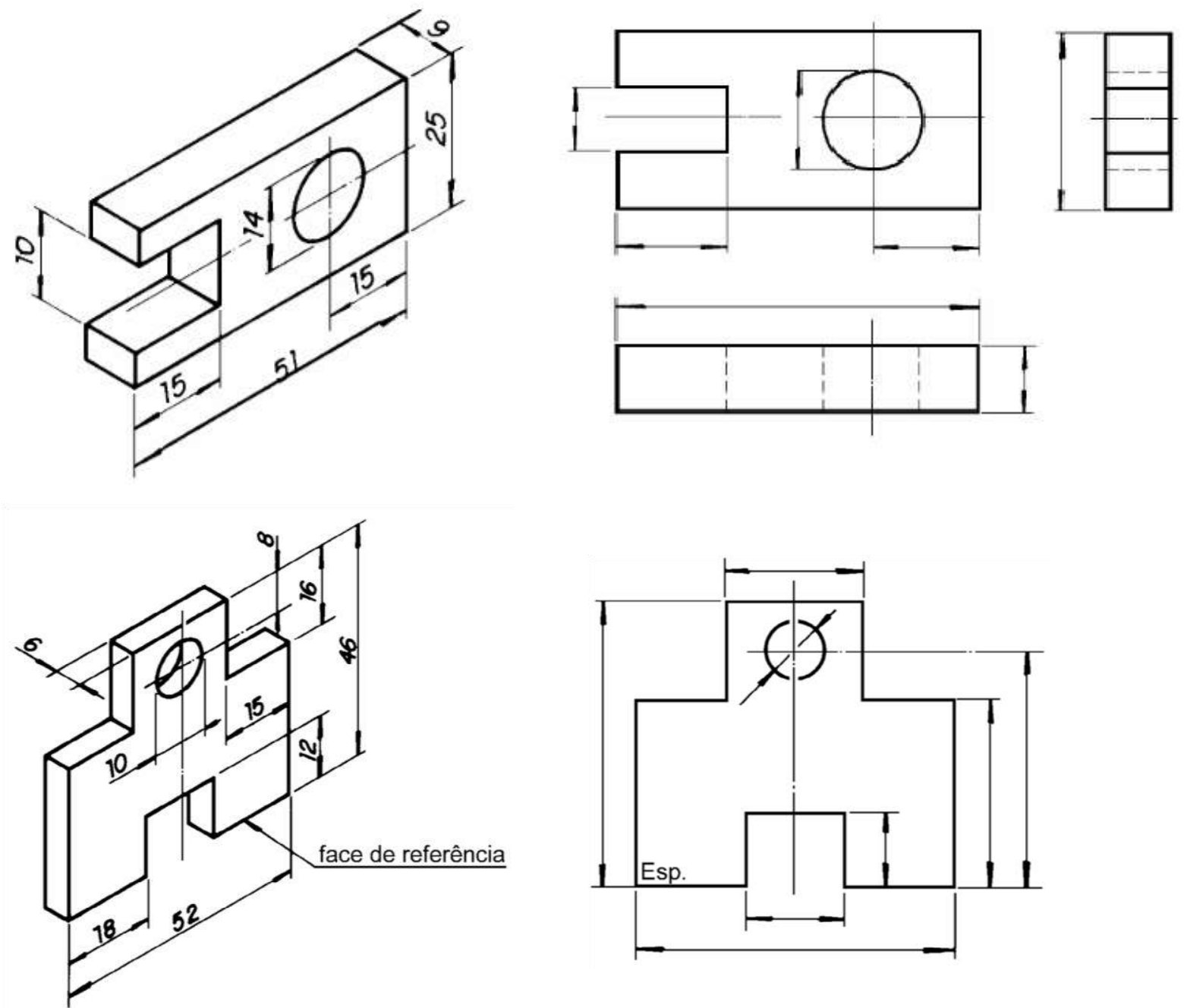

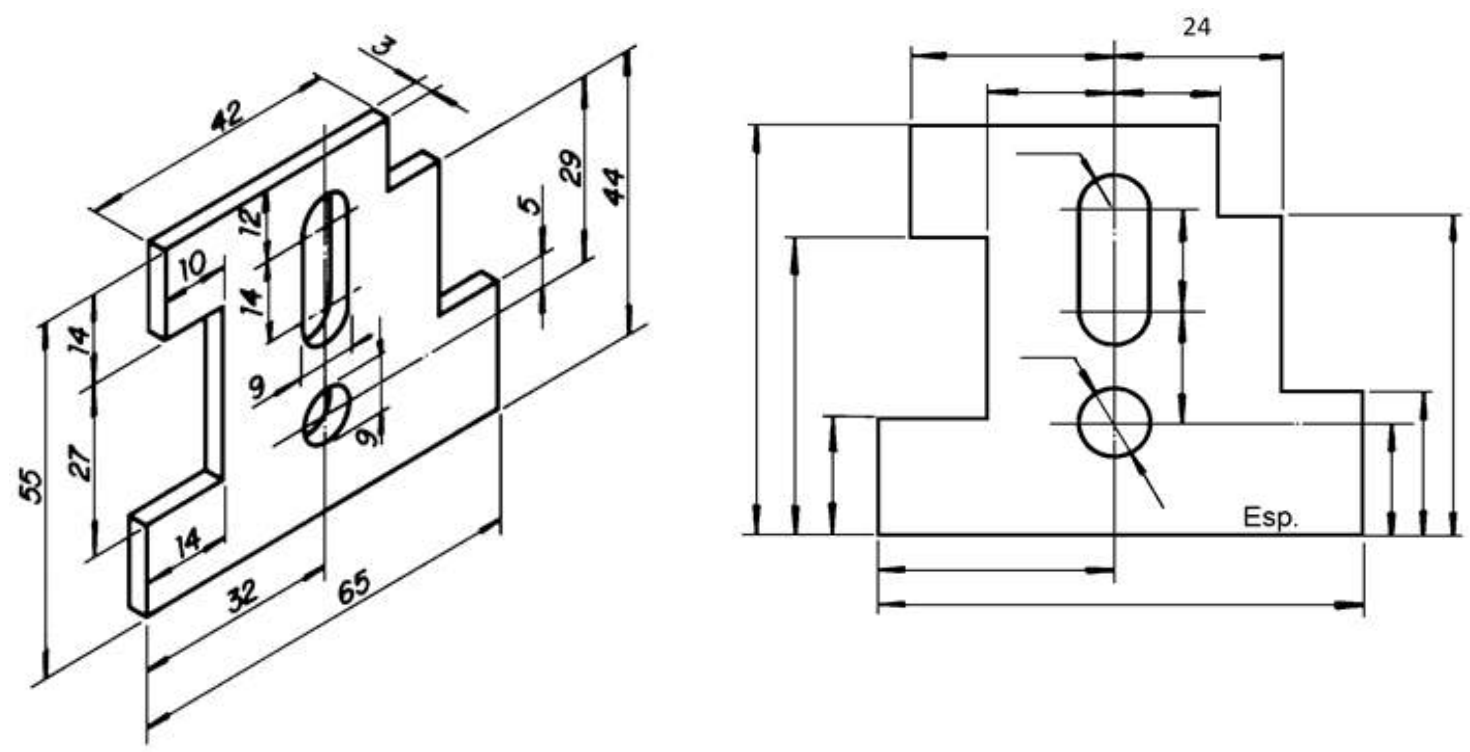

3. Desenhe à mão livre as projeções da peça abaixo (VF, VLE e VS), colocando eixos de simetria (quando necessário) e fazendo a cotagem.
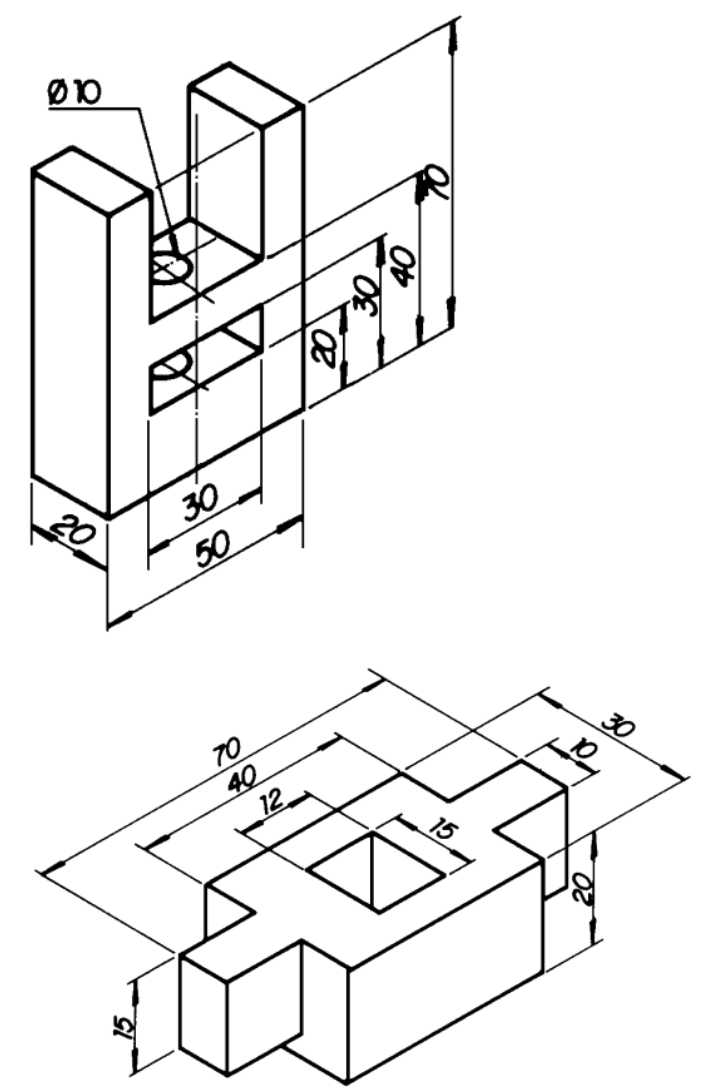


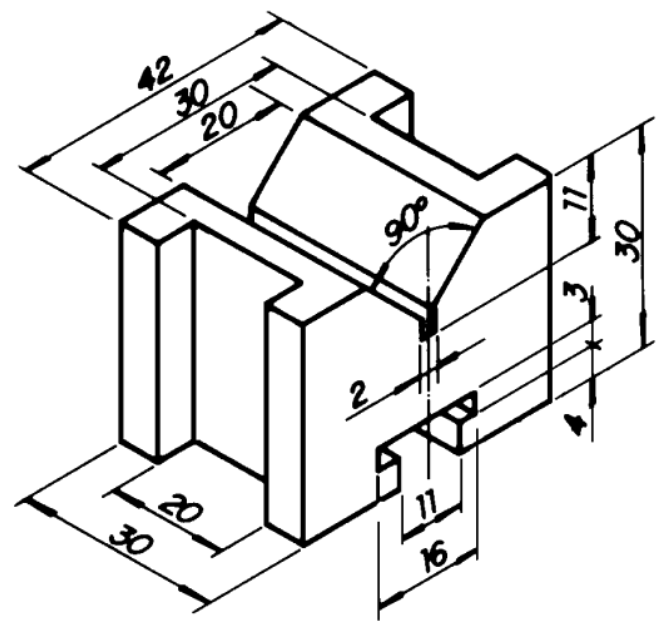

4. Com o auxílio dos instrumentos, represente as três vistas ortográficas dos objetos: VF, VS e VLE.

a) Escala 5:1

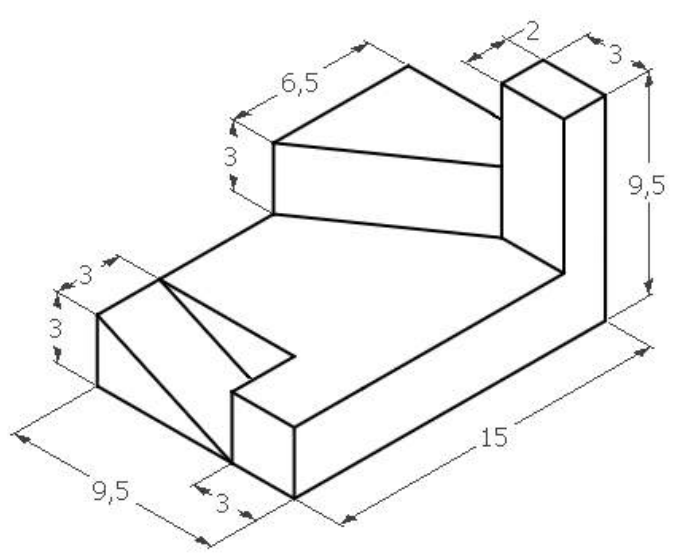

b) Escala 2:1

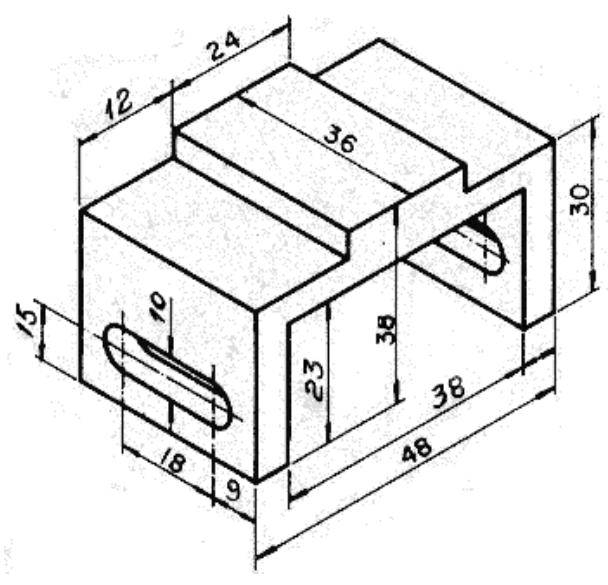


c) Escala 1:1

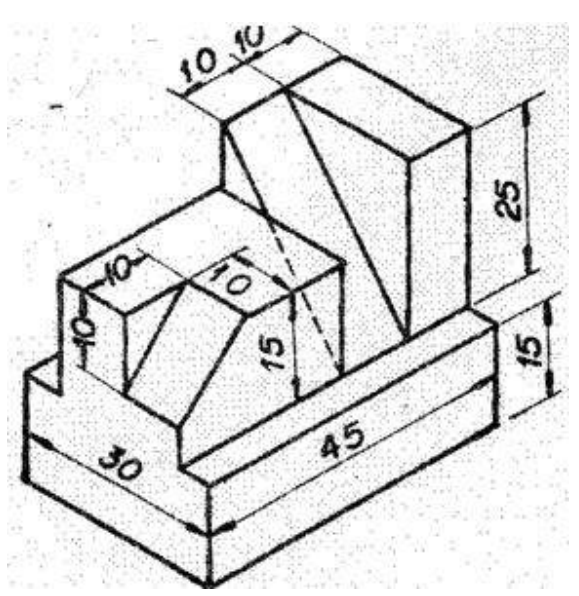

d) Escala 1:1

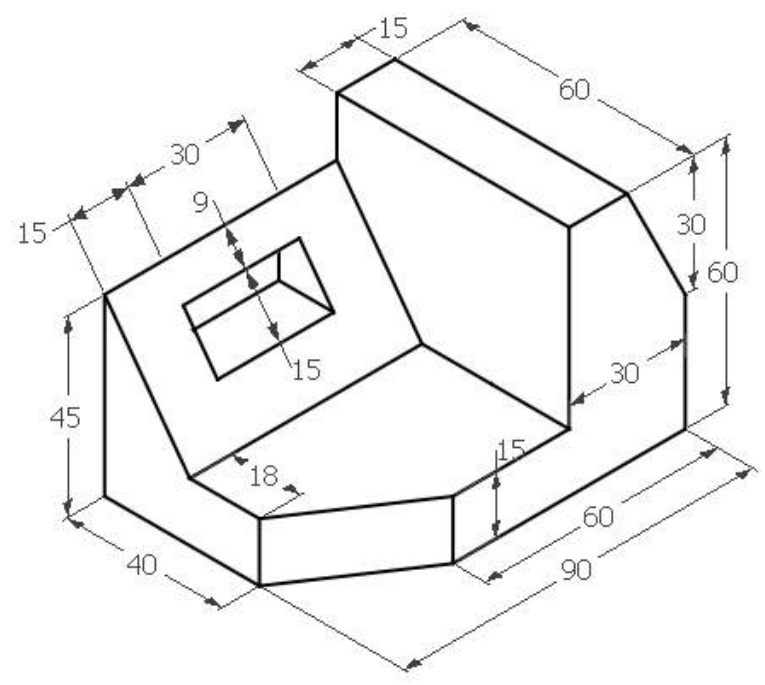

e) Escala 1:1

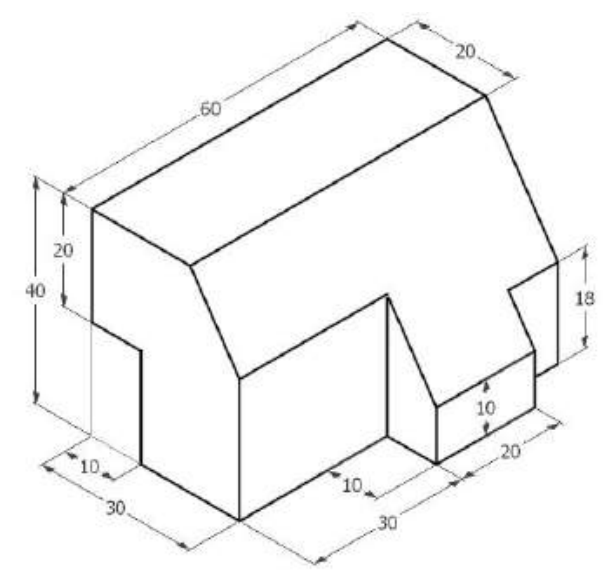


f) Escala 10:1

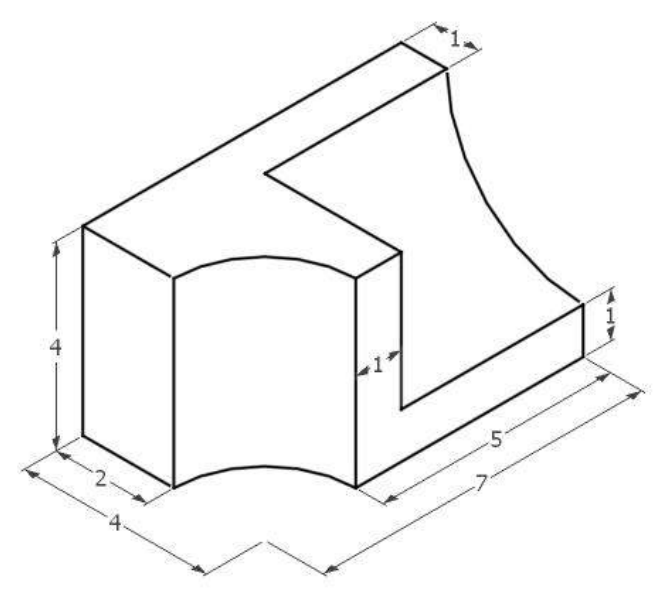

g) Escala 10:1

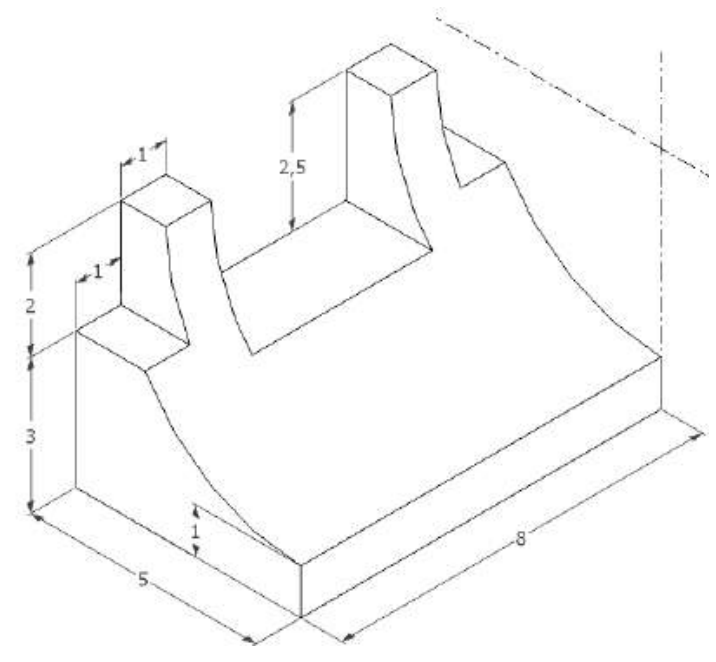

h) Escala 1:1

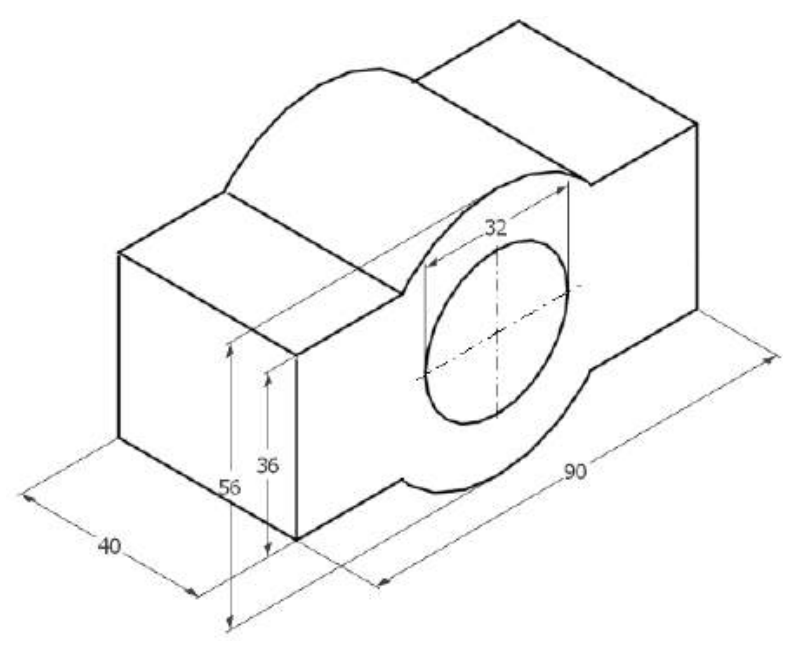


i) Escala 1:1 (apenas a Vista Frontal e Superior)

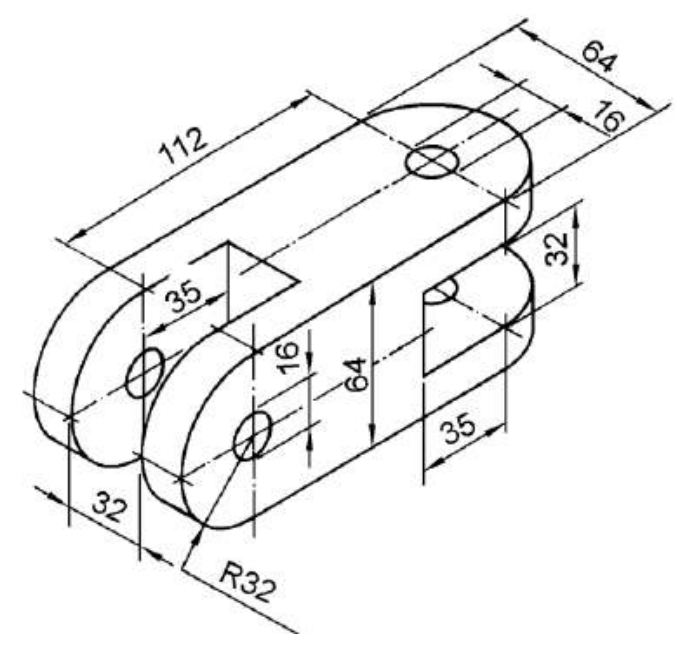




\section{CAPÍTULO 8}

\section{SÓLIDOS GEOMÉTRICOS}

Os sólidos geométricos têm três dimensões: comprimento, largura e altura. Embora existam infinitos sólidos geométricos, apenas alguns, que aprestam determinadas propriedades, são estudados pela geometria.

Os sólidos geométricos são separados do resto do espaço por superfícies que os limitam. E essas superfícies podem ser planas ou curvas.

Dentre os sólidos geométricos limitados por superfícies planas, temos os prismas, o cubo e as pirâmides. Dentre os sólidos geométricos limitados por superfícies curvas, temos o cilindro, o cone e a esfera, que são também chamados de sólidos de revolução.

É muito importante que você conheça bem os principais sólidos geométricos porque, por mais complicada que seja, a forma de uma peça sempre vai ser analisada como o resultado da combinação de sólidos geométricos ou de suas partes.

\subsection{PRISMA}

O prisma é um sólido geométrico limitado por polígonos. Ele é constituído de vários elementos. Para quem lida com desenho técnico é muito importante conhecêlos bem. Vejam quais são eles nesta ilustração:
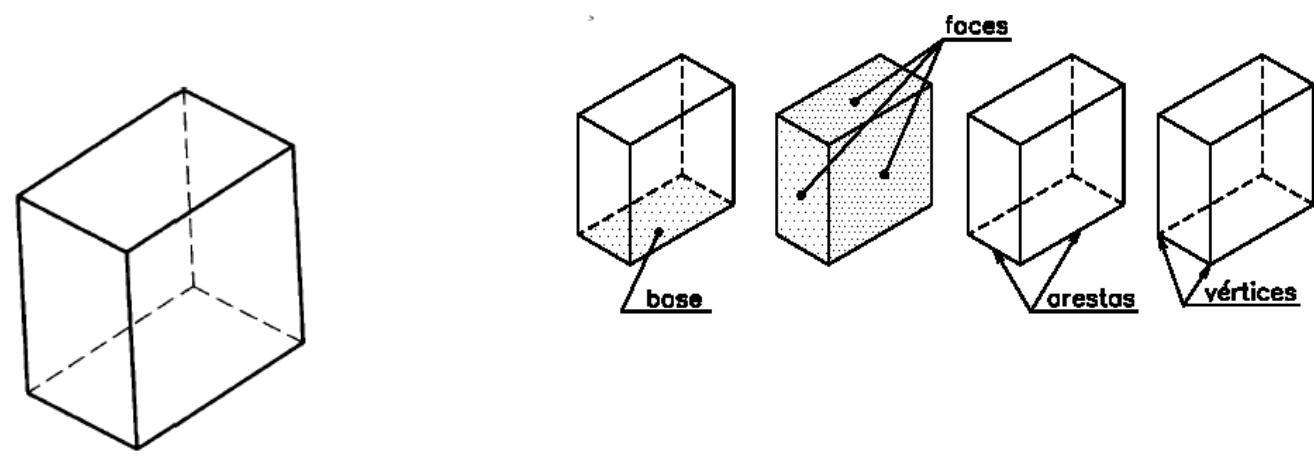


\subsection{PIRÂMIDES}

A pirâmide é outro sólido geométrico limitado por polígonos. Outra maneira de imaginar a formação de uma pirâmide consiste em ligar todos os pontos de um polígono qualquer a um ponto $\mathrm{P}$ do esboço.

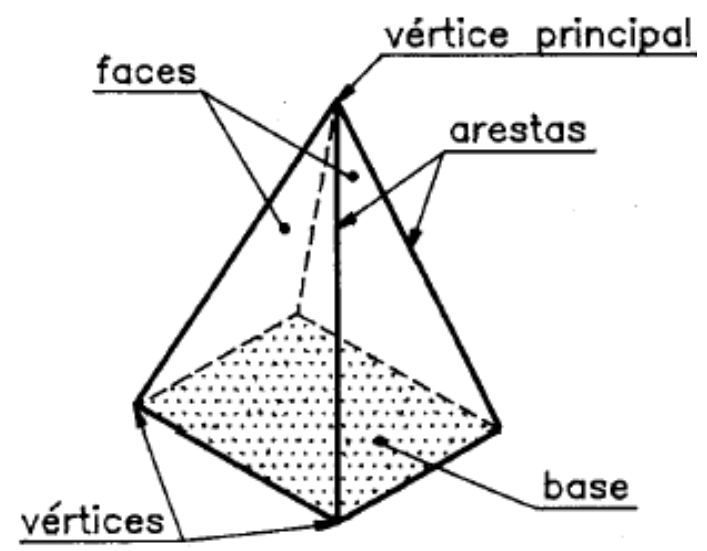

\subsection{SÓLIDOS DE REVOLUÇÃO}

São chamados sólidos de revolução, os sólidos geométricos formados pela rotação de figuras planas em torno de um eixo. O cilindro, o cone e a esfera são os principais sólidos de revolução.

\subsection{CILINDRO}

É o sólido geométrico formado pela revolução de um retângulo em torno de um de seus lados.

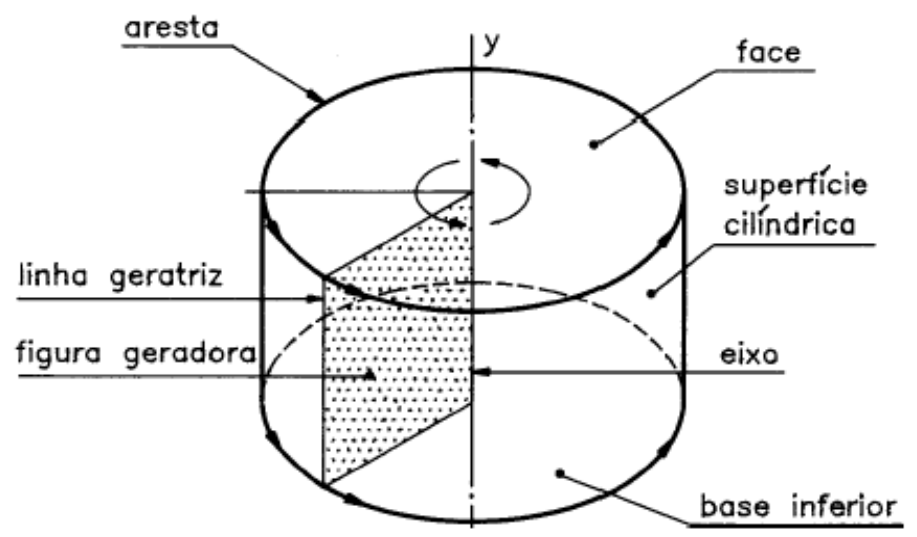

\subsection{CONE}


Cone é o sólido gerado pela revolução de um triângulo retângulo em torno de um de seus catetos que se confunde com o eixo.

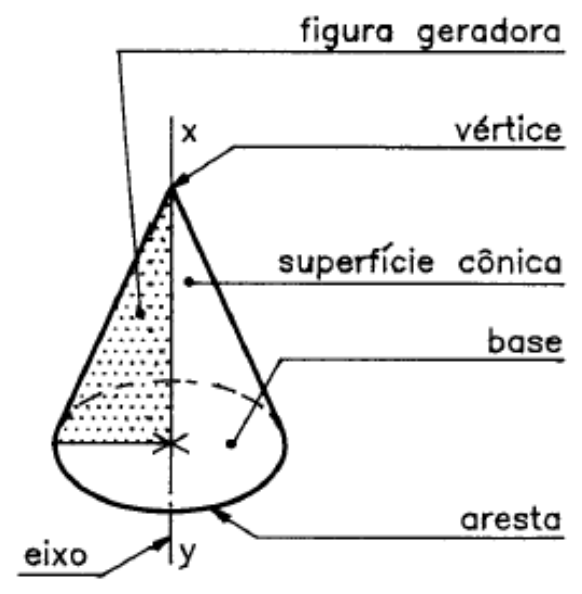

\subsection{ESFERA}

É o sólido limitado por superfície curva, cujos pontos são eqüidistantes de um ponto inferior chamado centro. O raio da esfera é o segmento de reta que une o centro da esfera a qualquer um de seus pontos. Diâmetro da esfera é o segmento de reta que passa pelo centro da esfera unindo dois de seus pontos.

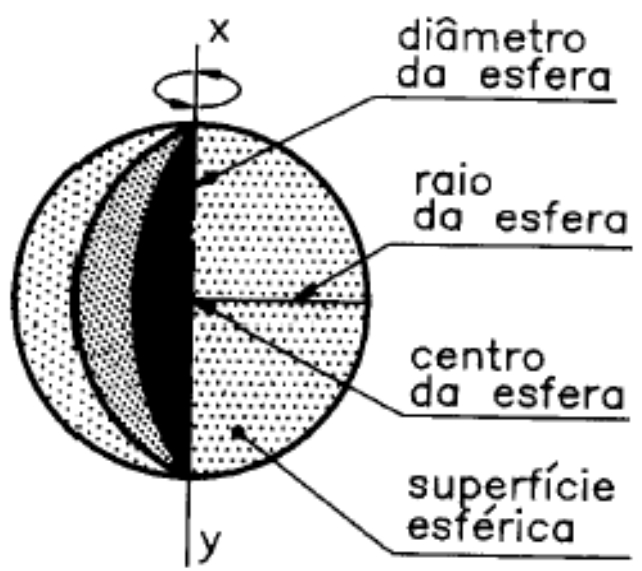




\subsection{SÓLIDOS GEOMÉTRICOS TRUNCADOS}

Quando um sólido geométrico é cortado por um plano, resultam novas figuras geométricas: os sólidos geométricos truncados. Veja alguns exemplos de sólidos truncados, com seus respectivos nomes:
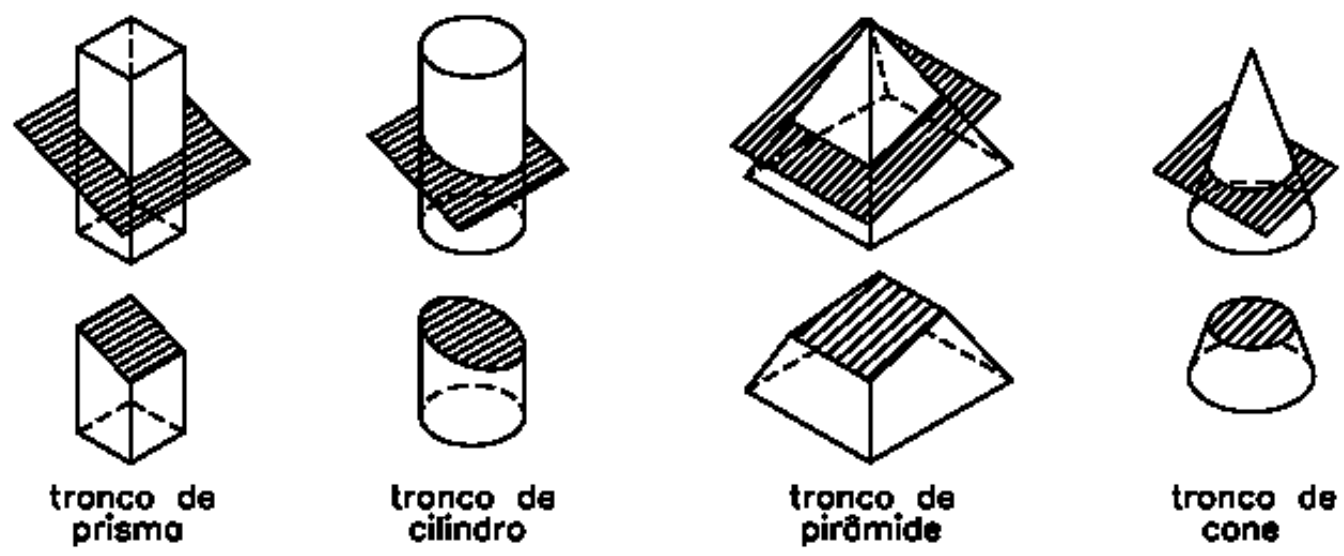

\subsection{SÓLIDOS GEOMÉTRICOS VAZADOS}

Os sólidos geométricos que apresentam partes ocas são chamados sólidos geométricos vazados.
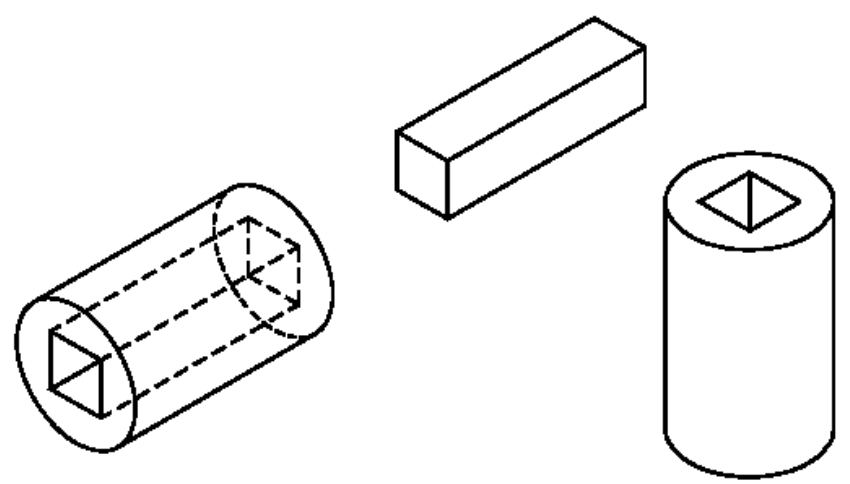

\subsection{TERMOS TÉCNICOS}

O uso de termos técnicos dentro da área mecânica, mais especificamente dentro do desenho técnico é muito importante, pois exprime situações de usinagem e montagem de conjuntos mecânicos. Os mais comuns são: 

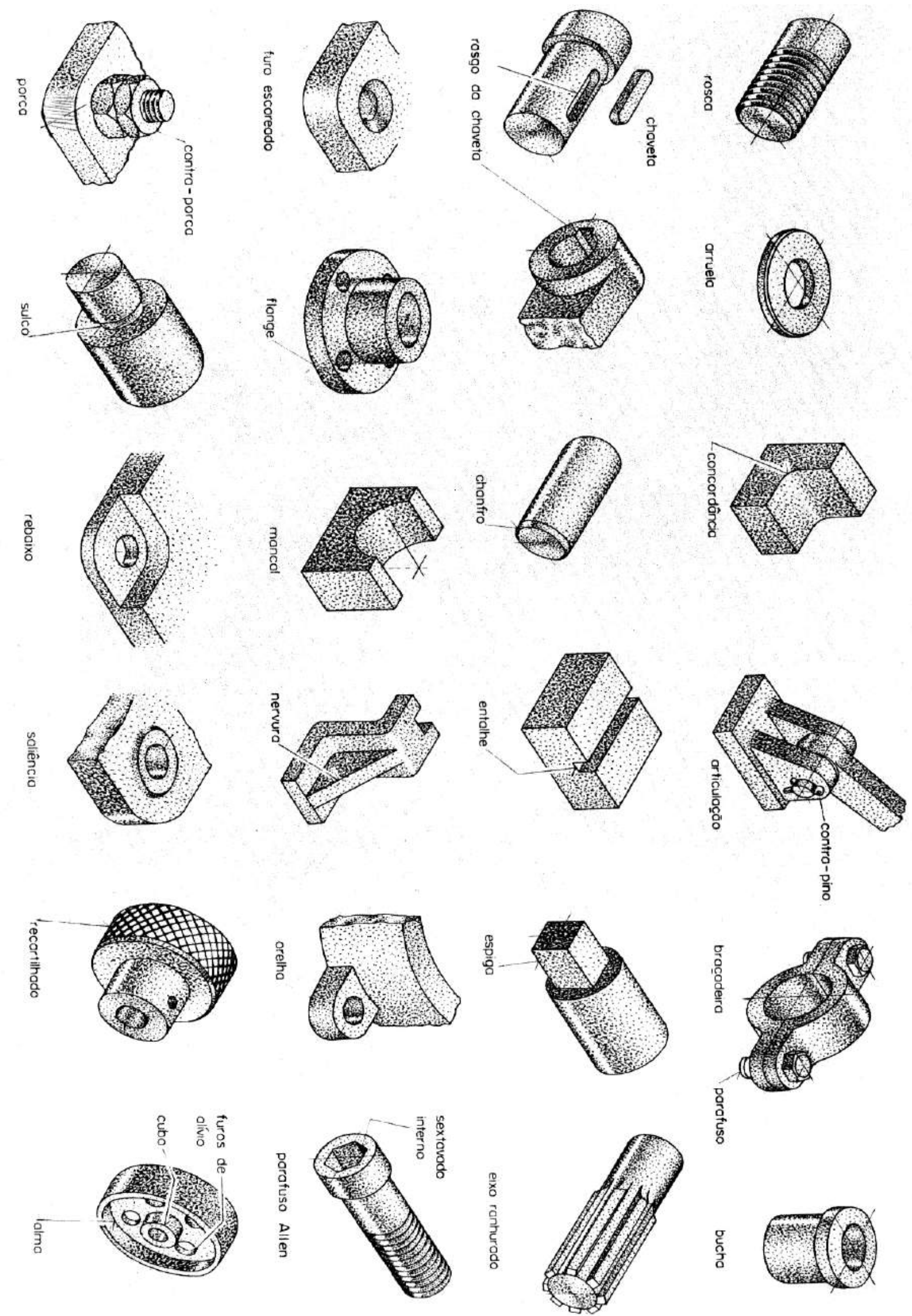


\section{CAPÍTULO 9}

\section{PERSPECTIVAS}

Quando olhamos para um objeto, temos a sensação de profundidade e relevo. As partes que estão mais próximas de nós parecem maiores e as partes mais distantes aparentam ser menores.

A fotografia mostra um objeto do mesmo modo como ele é visto pelo olho humano, pois transmite a idéia de três dimensões: comprimento, largura e altura.

O desenho, para transmitir essa mesma idéia, precisa recorrer a um modo especial de representação gráfica: a perspectiva. Ela representa graficamente as três dimensões de um objeto em um único plano, de maneira a transmitir a idéia de profundidade e relevo.

Existem diferentes tipos de perspectiva. Veja como fica a representação de um cubo em três tipos diferentes de perspectiva:

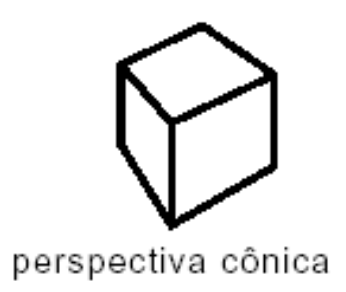

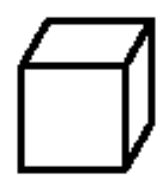

perspectiva cavaleira

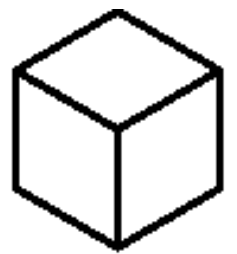

perspectiva isométrica

Cada tipo de perspectiva mostra o objeto de um jeito. Comparando as três formas de representação, você pode notar que a perspectiva isométrica È a que dá idéia menos deformada do objeto.

Isso quer dizer mesma; métrica quer dizer medida. A perspectiva isométrica mantém as mesmas proporções do comprimento, da largura e da altura do objeto representado. Além disso, o traçado da perspectiva isométrica é relativamente simples. Por essas razões, neste curso, você estudará esse tipo de perspectiva.

\subsection{PERSPECTIVAS CÔNICA}

É um sistema perspectivo fundamentado na projeção cônica do objeto sobre um quadro transparente. Corresponderia a desenhar sobre a lâmina de vidro a imagem do objeto, mantendo o olho imóvel num ponto (ponto de vista). 
Conforme o cubo tiver nenhuma, uma ou duas das suas três direções fundamentais paralelas ao quadro, a respectiva projeção cônica terá três, dois ou apenas um ponto de fuga.

Este sistema implica em construções geométricas bastante complexas, exigindo, normalmente, o uso de desenho instrumental; em conseqüência, a transformação das medidas do espaço para as medidas do plano e vice-versa não pode ser feita de modo simples e imediato.

Por isso, em Desenho Técnico, e especialmente no esboço à mão livre, é utilizada com mais freqüência, os sistemas de perspectivas paralelas que não apresentam os inconvenientes mencionados acima.

Como o nome indica, esses sistemas que serão tratados à seguir, fundamentam-se nas projeções paralelas (cilíndricas), em que todas as linhas do feixe projetante são paralelas.
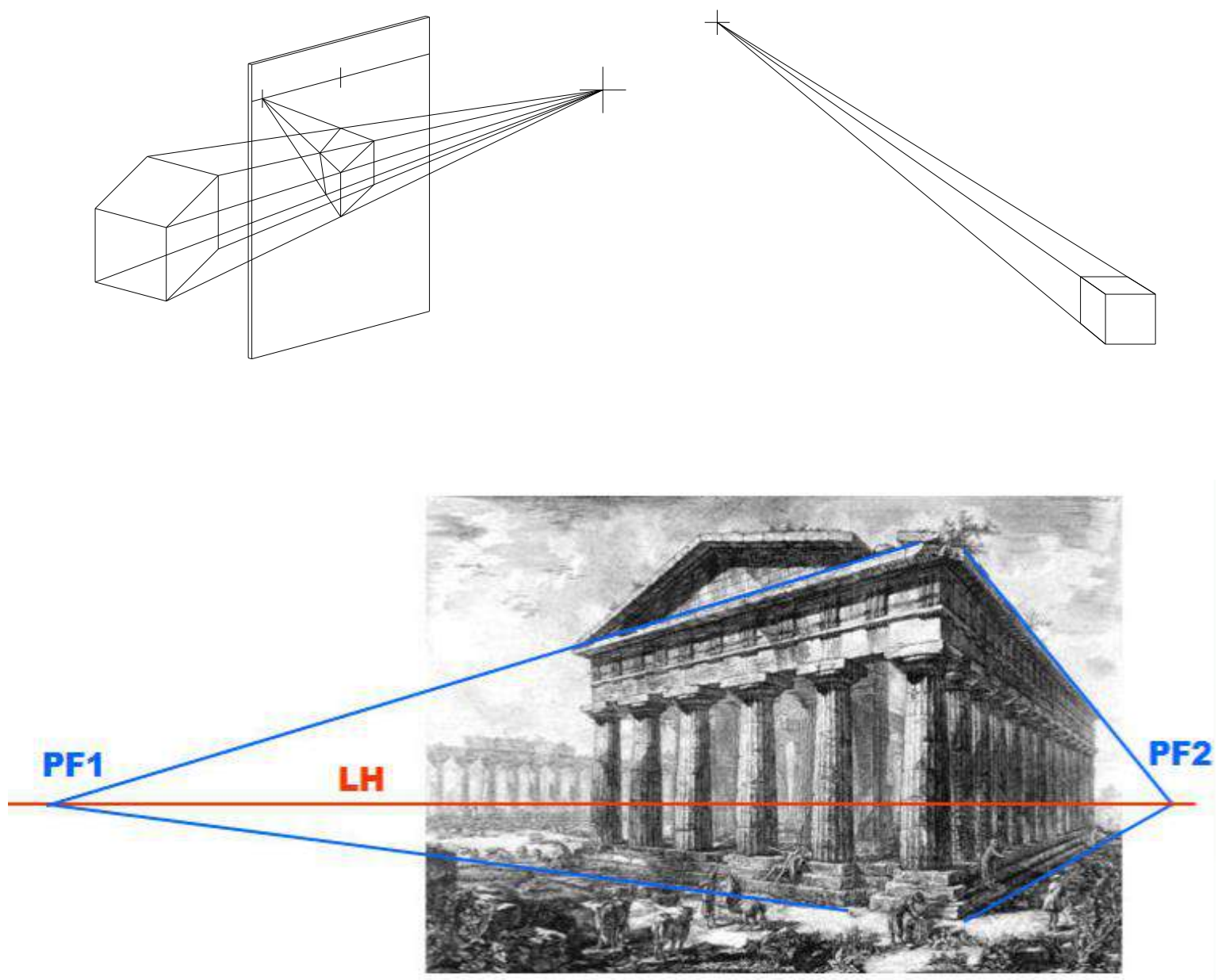

Exemplo de Imagem com dois pontos de fuga. 


\subsection{PERSPECTIVAS CAVALEIRA}

É o sistema perspectivo obtido quando o feixe paralelo (cilíndrico) de projetantes é oblíquo em relação ao quadro, sendo colocada paralelamente ao mesmo a face mais importante do objeto. No desenho sobre a lâmina de vidro, é obtida uma projeção oblíqua quando o olho é movido ao mesmo tempo em que a ponta do lápis, de maneira a que as visuais que unem cada ponto do objeto ao correspondente ponto do desenho e ao olho, sejam sempre paralelas entre si e a uma direção oblíqua em relação ao vidro.

$\mathrm{Na}$ realidade, as faces do cubo, paralelas ao quadro, permanecem em verdadeira grandeza, enquanto as arestas perpendiculares ao quadro se projetam inclinadas, sofrendo uma certa deformação.

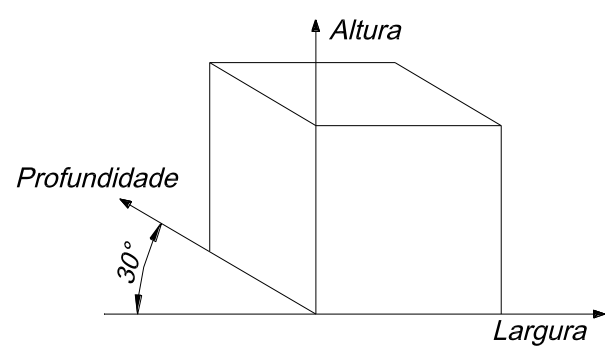

Cavaleira $30^{\circ}$

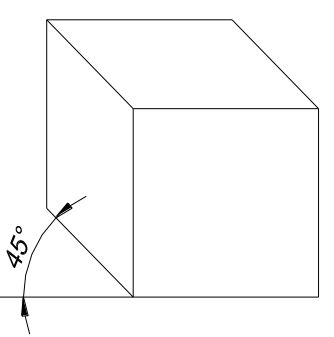

Cavaleira $45^{\circ}$

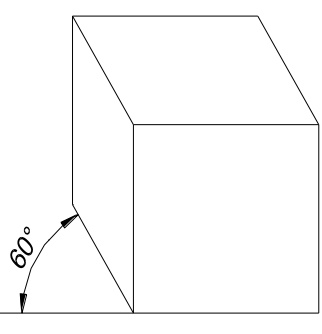

Cavaleira $60^{\circ}$

\begin{tabular}{|c|c|c|c|}
\hline \multirow{2}{*}{ TIPOS } & \multicolumn{3}{|c|}{ Coeficiente de Redução das Escalas dos Eixos } \\
\cline { 2 - 4 } & Largura & Altura & Profundidade \\
\hline Cavaleira $30^{\circ}$ & 1 & 1 & $2 / 3$ \\
\hline Cavaleira $45^{\circ}$ & 1 & 1 & $1 / 2$ \\
\hline Cavaleira $60^{\circ}$ & 1 & 1 & $1 / 3$ \\
\hline
\end{tabular}

\subsection{PERSPECTIVA ISOMÉTRICA}

\subsubsection{PERSPECTIVA ISOMÉTRICA SIMPLIFICADA}

Em quase todos os usos práticos do sistema isométrico não se considera a redução que sofrem as linhas, marcando-se sobre os eixos seus comprimentos reais. Assim, teremos uma figura com uma forma exatamente igual, mas um pouco maior, na proporção de 1 para ,23, linear, e seu volume de 1,00m3 para 1,23m3 (figura a seguir). 

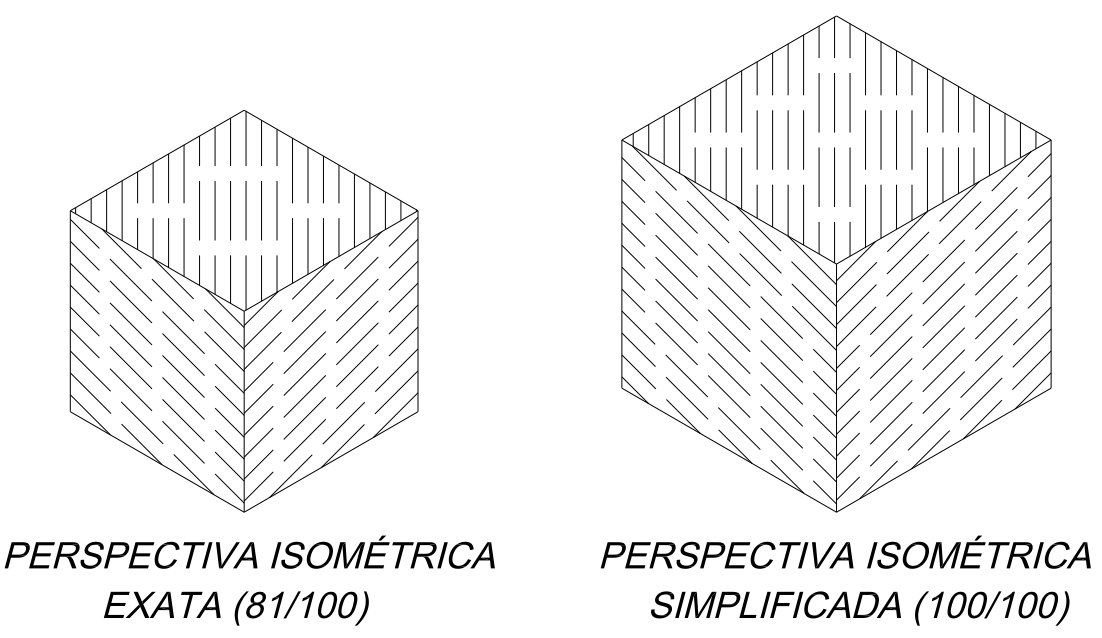

\subsubsection{TRAÇADO DA PERSPERCTIVA ISOMÉTRICA SIMPLIFICADA} EIXOS ISOMÉTRICOS

O desenho da perspectiva isométrica é baseado num sistema de três semiretas que têm o mesmo ponto de origem e formam entre si três ângulos de $120^{\circ}$. Essas semi-retas, assim dispostas, recebem o nome de eixos isométricos. Cada uma das semi-retas é um eixo isométrico. Os eixos isométricos podem ser representados em posições variadas, mas sempre formando, entre si, ângulos de $120^{\circ}$. Neste curso, os eixos isométricos serão representados sempre na posição indicada na figura anterior. $O$ traçado de qualquer perspectiva isométrica parte sempre dos eixos isométricos.
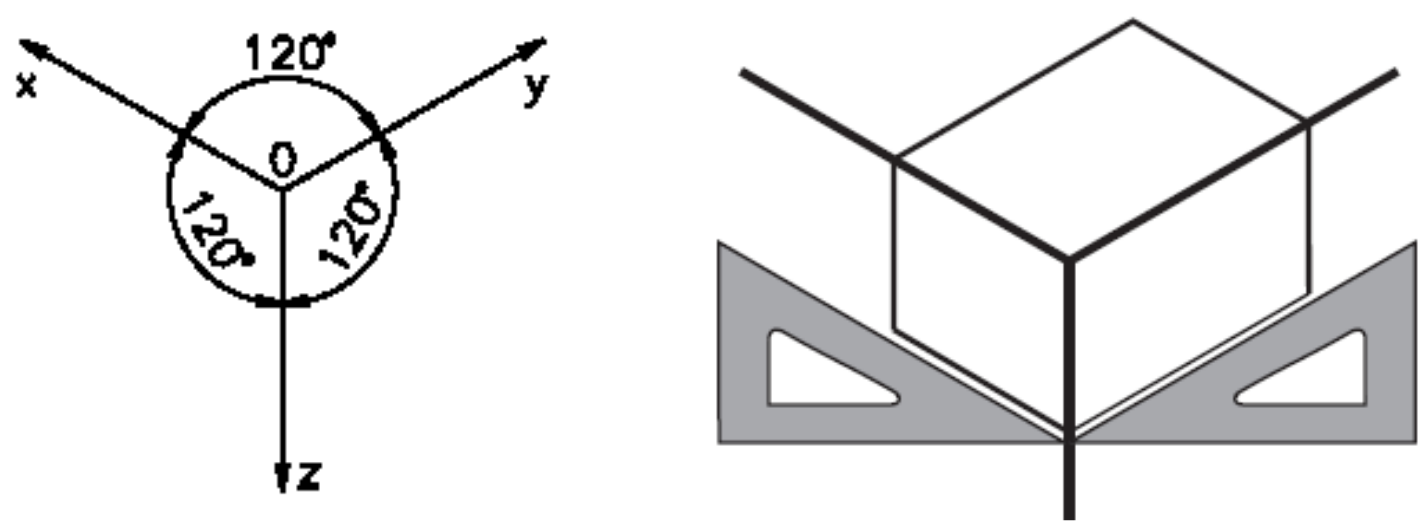


\subsubsection{LINHA ISOMÉTRICA}

Qualquer reta paralela a um eixo isométrico é chamada linha isométrica. Observe a figura a seguir:

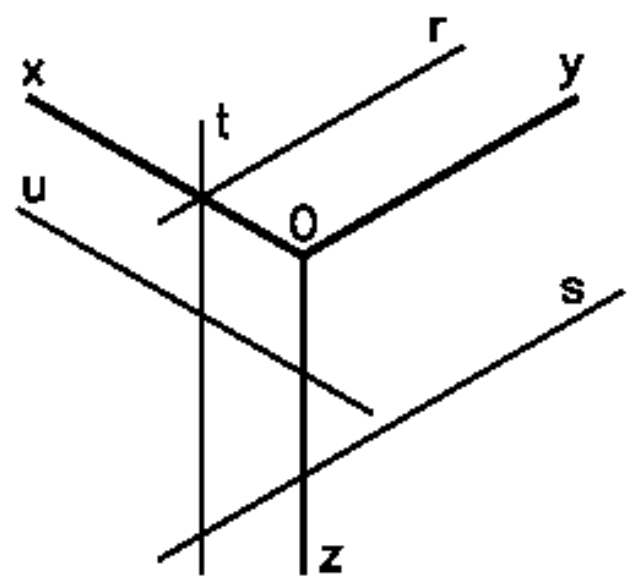

\subsubsection{TRAÇANDO A PERSPECTIVA ISOMÉTRICA}

Dadas as vistas principais de um objeto, parte-se de um ponto que representa o vértice $O$ do sólido envolvente e traçam-se os três eixos, que farão entre si ângulos de 120․ Em seguida, constrói-se o paralelepípedo envolvente do sólido com as maiores dimensões de largura, altura e profundidade, segundo a visibilidade desejada para os três planos. Analisando as vistas ortográficas, fazem-se cortes no sólido envolvente de acordo com as formas e dimensões dadas nas referidas vistas, adaptando, separadamente, cada vista no seu plano, até que se tenha o objeto desejado (Figura abaixo). As linhas ocultas não são habitualmente representadas em perspectiva.
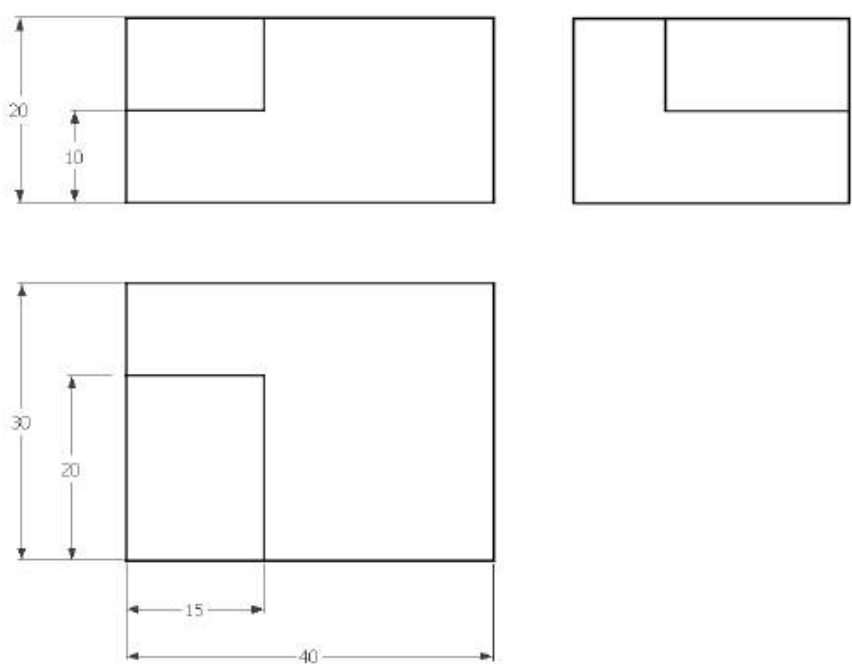
Construção da perspectiva isométrica simplificada de um objeto.
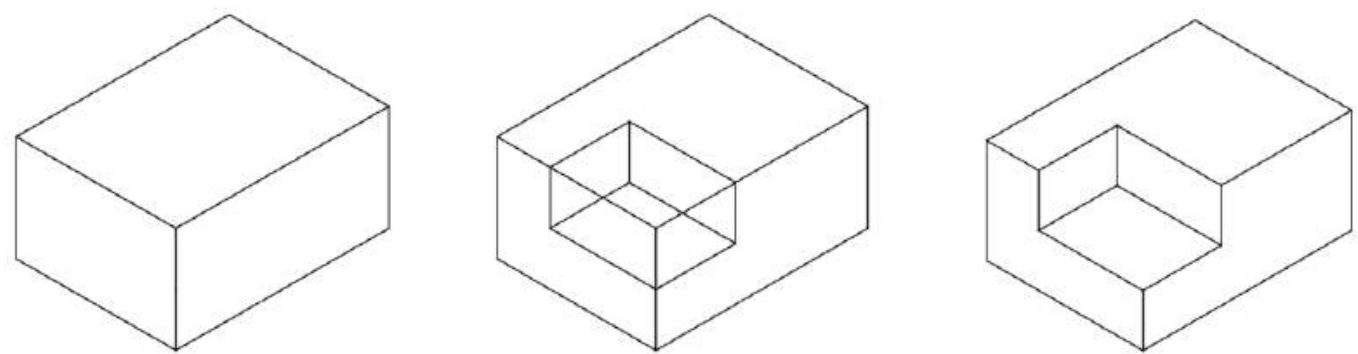

9.4 TRAÇANDO A PERSPECTIVA ISOMÉTRICA DE UM PRISMA - PASSOA-PASSO

O traçado da perspectiva será demonstrado em cinco fases apresentadas separadamente. Na prática, porém, elas são traçadas em um mesmo desenho. Em cada nova fase você deve repetir todos os procedimentos anteriores.

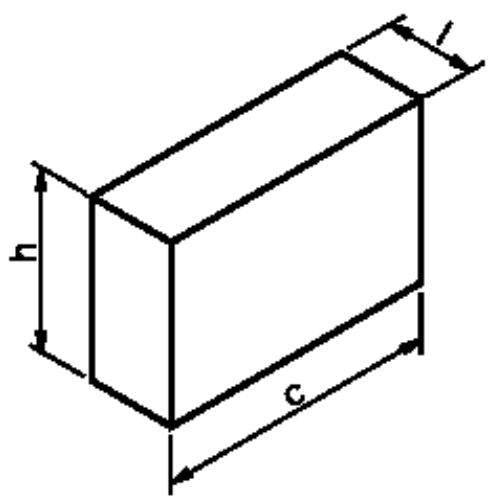

prisma retangular dimensões básicas:

$\mathrm{c}=$ comprimento;

I = largura;

$\mathrm{h}=$ altura

$1^{\circ}$ fase - Trace levemente, os eixos isométricos e indique o comprimento, a largura e a altura sobre cada eixo, tomando como base as medidas aproximadas do prisma representado na figura anterior.

$2^{\circ}$ fase - A partir dos pontos onde você marcou o comprimento e a altura, trace duas linhas isométricas que se cruzam. Assim ficará determinada a face da frente do modelo.
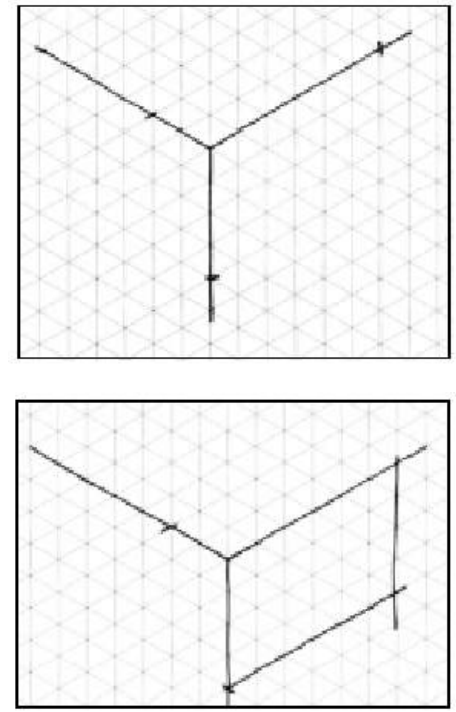
$3^{\circ}$ fase - Trace agora duas linhas isométricas que se cruzam a partir dos pontos onde você marcou o comprimento e a largura. Assim ficará determinada a face superior do modelo.

$4^{\circ}$ fase - E, finalmente, você encontrará a face lateral do modelo. Para tanto, basta traçar duas linhas isométricas a partir dos pontos onde você indicou a largura e a altura.

$5^{\circ}$ fase (conclusão) - Apague os excessos das linhas de construção. Depois, é só reforçar os contornos da figura e está concluído o traçado da perspectiva isométrica do prisma retangular.
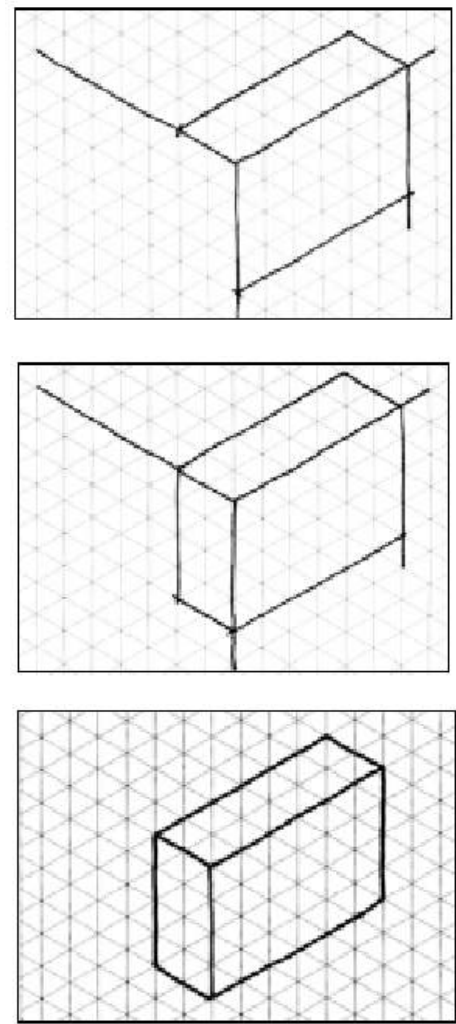

\subsection{PERSPECTIVA ISOMÉTRICA DE ELEMENTOS PARALELOS}

A forma do prisma com elementos paralelos deriva do prisma retangular. Por isso, o traçado da perspectiva do prisma com elementos paralelos parte da perspectiva do prisma retangular ou prisma auxiliar.

O traçado das cinco fases será baseado no modelo prismático indicado a seguir.

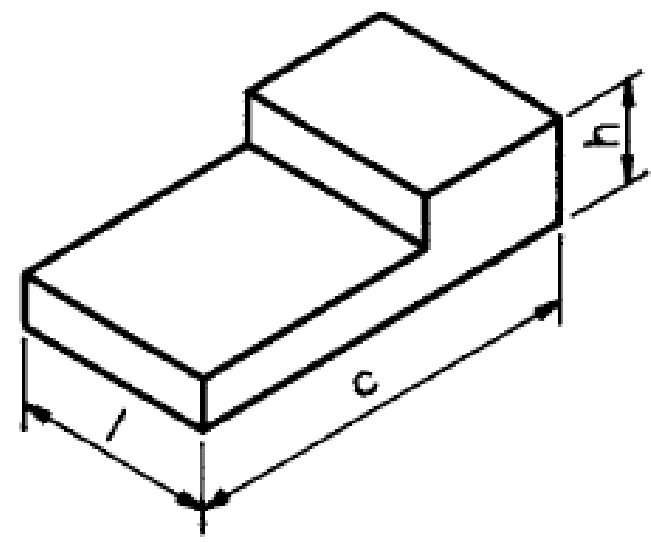

Prisma com rebaixo:

$\mathrm{c}=$ comprimento

I = largura

$\mathrm{h}=$ altura 
$1^{\circ}$ fase - Esboce a perspectiva isométrica do prisma auxiliar utilizando as medidas aproximadas do comprimento, largura e altura do prisma com rebaixo.

$2^{\circ}$ fase - $\mathrm{Na}$ face da frente, marque $\mathrm{o}$ comprimento e a profundidade do rebaixo e trace as linhas isométricas que 0 determinam.
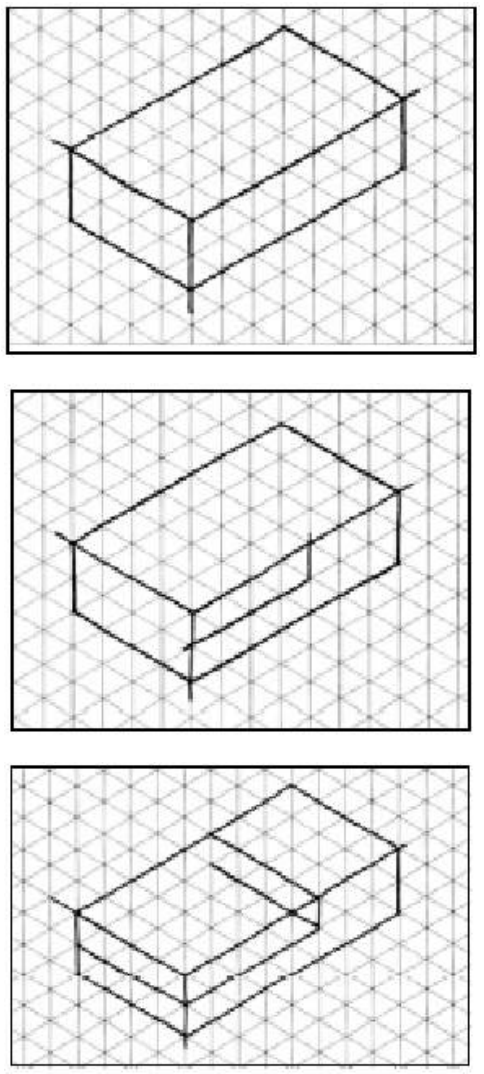

$3^{\circ}$ fase - Trace as linhas isométricas que determinam a largura do rebaixo. Note que a largura do rebaixo coincide com a largura do modelo.

$4^{\circ}$ fase - Complete o traçado do rebaixo.

$5^{\circ}$ fase (conclusão) - Finalmente, apague as linhas de construção e reforce os contornos do modelo.
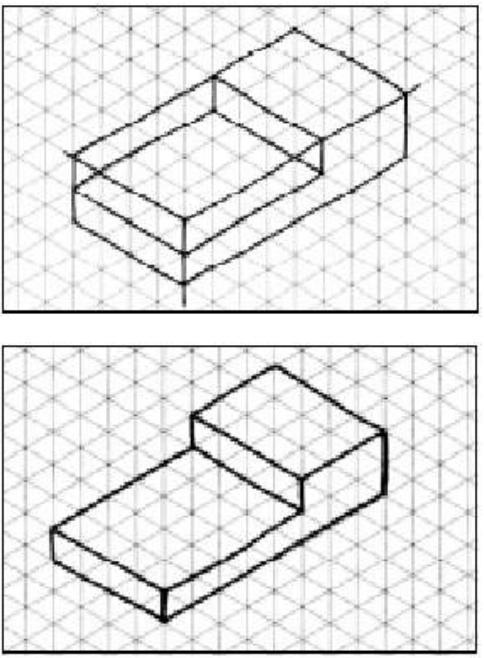

\subsection{PERSPECTIVA ISOMÉTRICA DE ELEMENTOS OBLÍQUOS}

Os modelos prismáticos também podem apresentar elementos oblíquos. Observe os elementos dos modelos abaixo: 


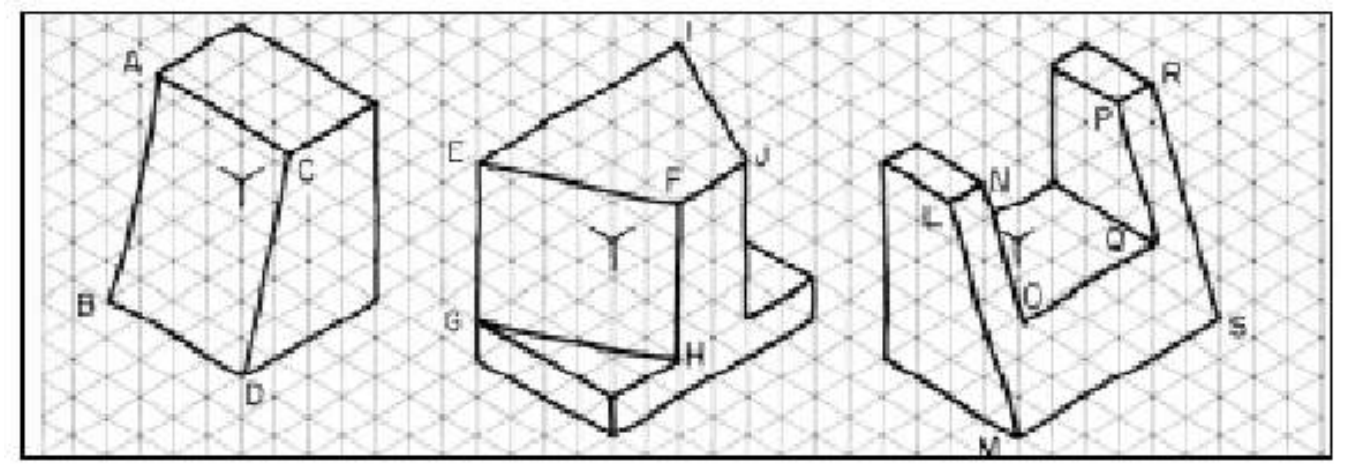

Esses elementos são oblíquos porque têm linhas que não são paralelas aos eixos isométricos. Nas figuras anteriores, os segmentos de reta: $A B, C D, E F, G H, I J$, LM, NO, PQ e RS são linhas não isométricas que formam os elementos oblíquos. O traçado da perspectiva isométrica de modelos prismáticos com elementos oblíquos também será demonstrado em cinco fases.

O modelo a seguir servir. de base para a demonstração do traçado. $O$ elemento oblíquo deste modelo chama-se chanfro.

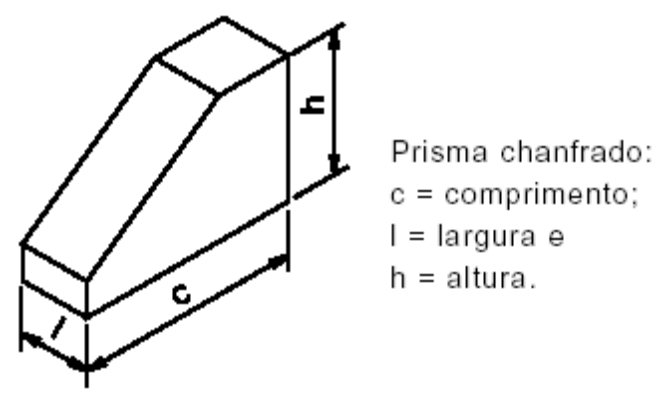

$1^{\circ}$ fase - Esboce a perspectiva isométrica do prisma auxiliar, utilizando as medidas aproximadas do comprimento, largura e altura do prisma chanfrado.

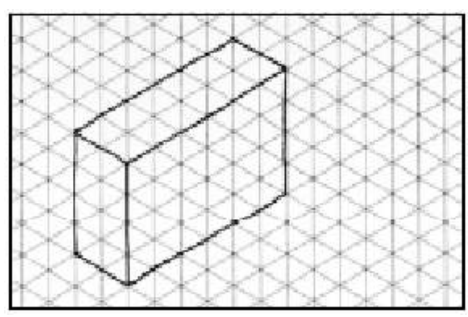

$2^{\circ}$ fase - Marque as medidas do chanfro na face da frente e trace a linha não isométrica que determina o elemento.

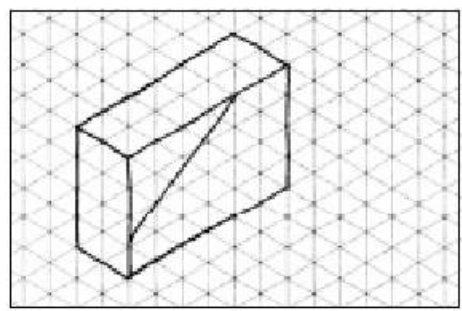


$3^{\circ}$ fase - Trace as linhas isométricas que determinam a largura do chanfro.

$4^{\circ}$ fase - Complete o traçado do elemento.
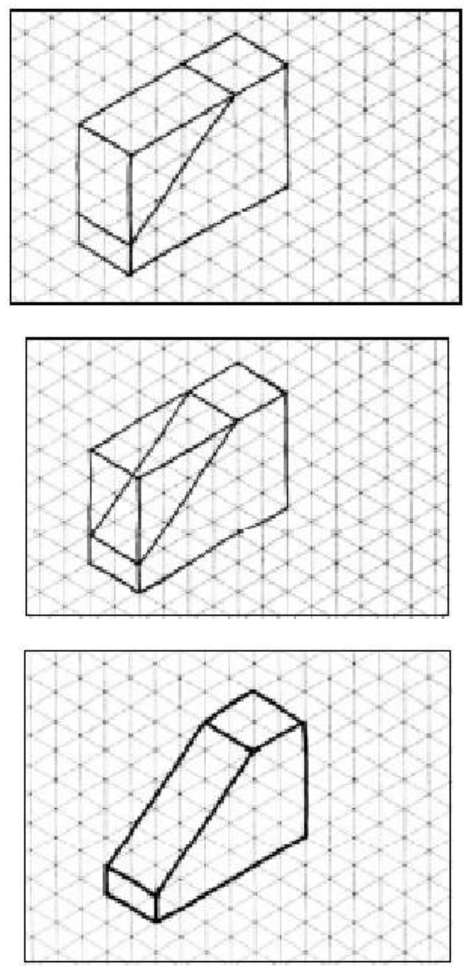

$5^{\circ}$ fase - Agora é só apagar as linhas de construção e reforçar as linhas de contorno do modelo.

\subsection{PERSPECTIVA ISOMÉTRICA DO CÍRCULO}

Um círculo, visto de frente, tem sempre a forma redonda. Entretanto, quando giramos o círculo. Imprimimos um movimento de rotação ao círculo, ele aparentemente muda, pois assume a forma de uma elipse.
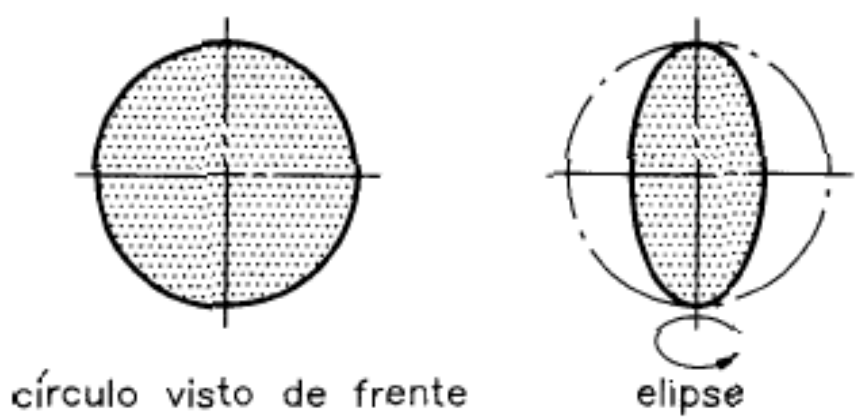

Para obter a perspectiva isométrica de circunferências e de arcos de circunferências utilizamos a chamada elipse isométrica.

Uma circunferência pode ser inscrita num quadrado, e esse, ao ser perspectivado, transforma-se num losango, que terá uma elipse inscrita.

Para executar o desenho isométrico das circunferências, são executadas as seguintes etapas: 
1) Desenha-se o quadrado $A B C D$ que circunscreve a circunferência. Traçam-se os eixos isométricos e marcam-se os lados do quadrado nos eixos. Tem-se agora o losango ABCD (Figura abaixo).

Figura - Etapa 1 da construção da perspectiva isométrica de uma circunferência.
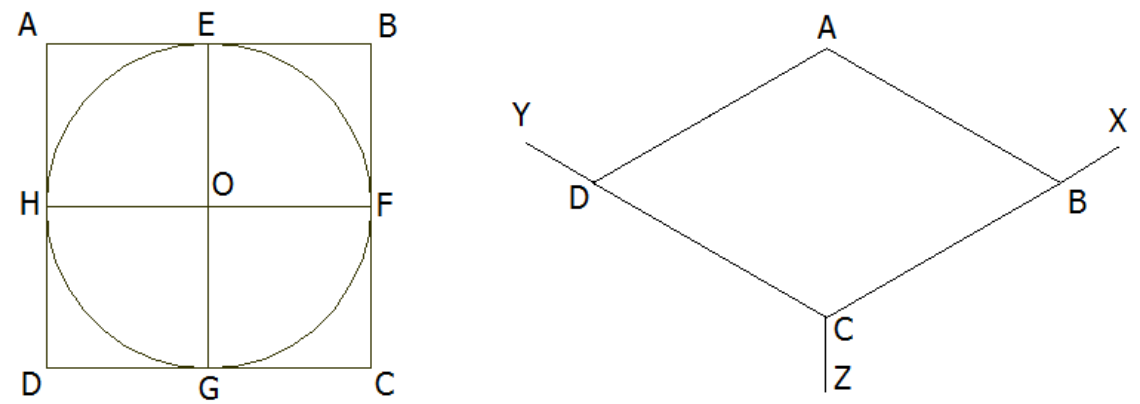

2) Marque os pontos médios nas arestas, conforme a figura a seguir:

a) entre $A$ e B, gerando o ponto "E";

b) entre B e C, gerando o ponto " $F$ ";

c) entre C e D, gerando o ponto " $G$ ";

d) entre $B$ e A, gerando o ponto "H".

Figura - Etapa 2 da construção dos pontos médios da PI de uma circunferência.

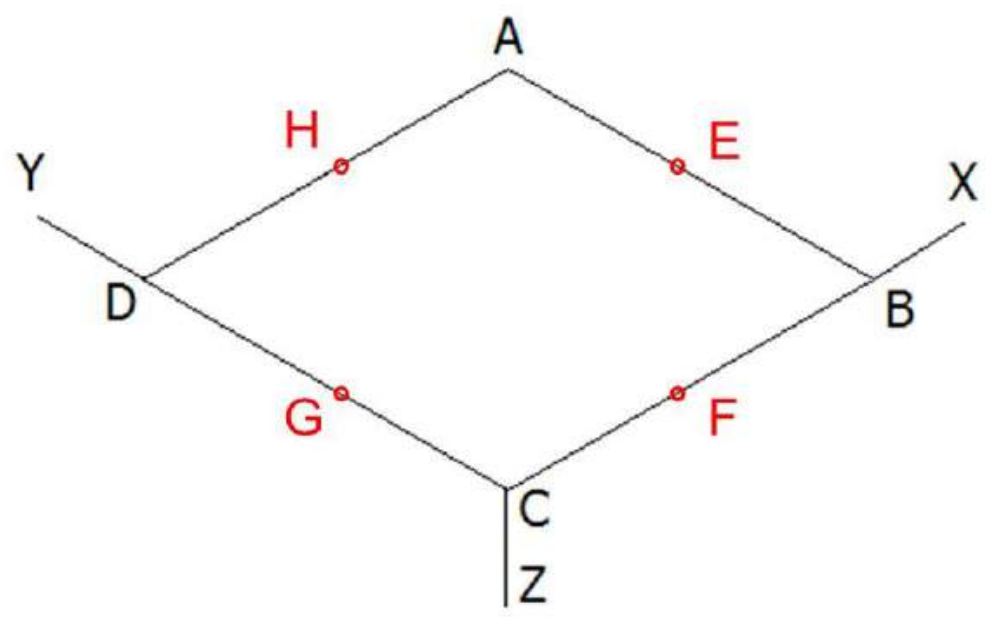

3) Através dos vértices de maior ângulo (120), trace uma reta até os pontos opostos:

a) do ponto $A$ até o ponto $F$;

b) do ponto $A$ até o ponto $G$;

c) do ponto $\mathrm{C}$ até o ponto $\mathrm{H}$;

d) do ponto $\mathrm{C}$ até o ponto $\mathrm{E}$.

Catapan, Strobel e Santana (2020) 
Figura - Etapa 2 da construção da perspectiva isométrica de uma circunferência.

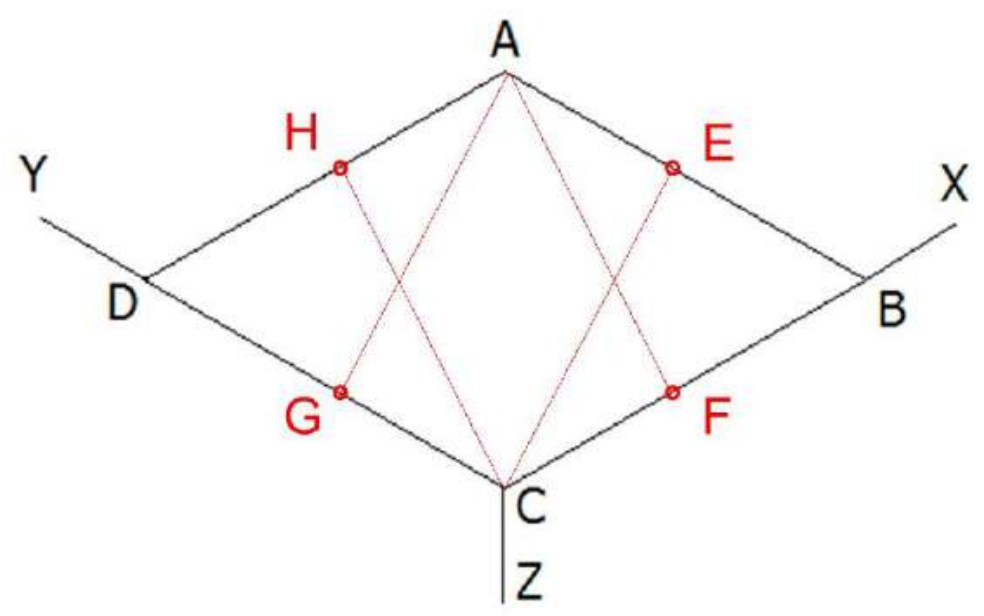

4) Com a ponta seca do compasso nos vértices de maior ângulo (120ํ) (neste caso no $\mathrm{C}$ e A), traçam-se os arcos HE e GF respectivamente.

Figura - Etapa 3 da construção dos arcos maiores de uma circunferência em PI.
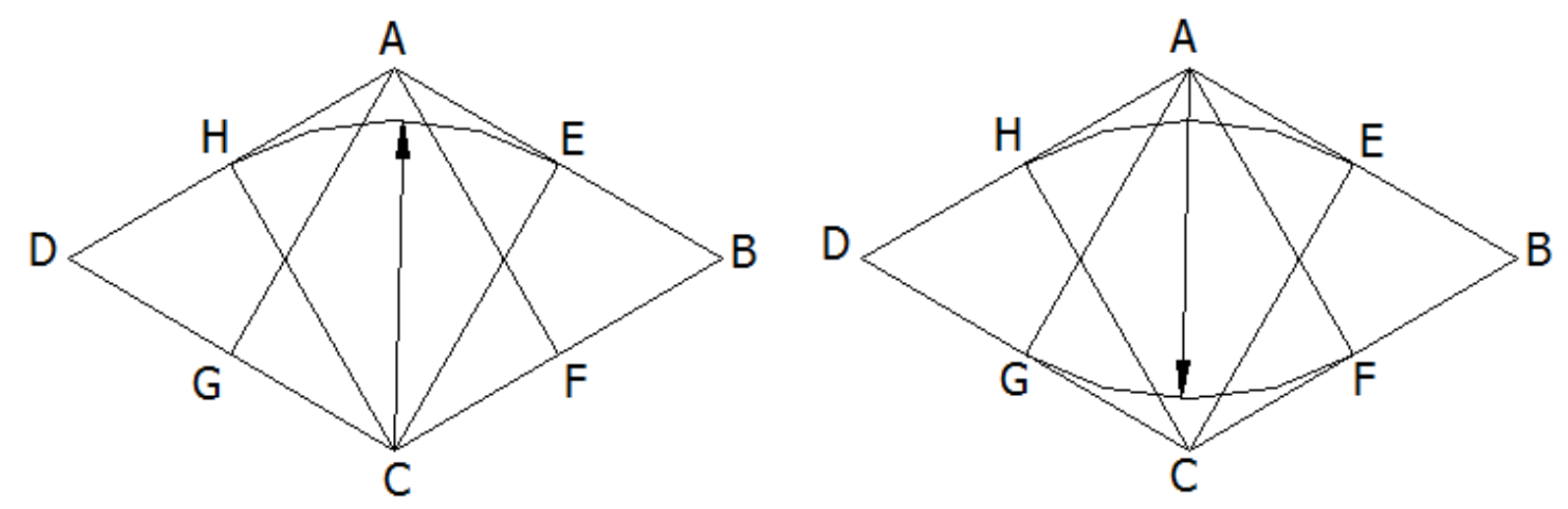

5) Após o passo anterior, são gerados os pontos "I" e "J", que são os cruzamentos das retas feitas na etapa 3. Com centro (ponta-seca) nos pontos I e J, traçam-se os arcos EF e HG, completando a elipse isométrica. 
Figura - Etapa 5 da construção dos arcos menores de uma circunferência em PI.

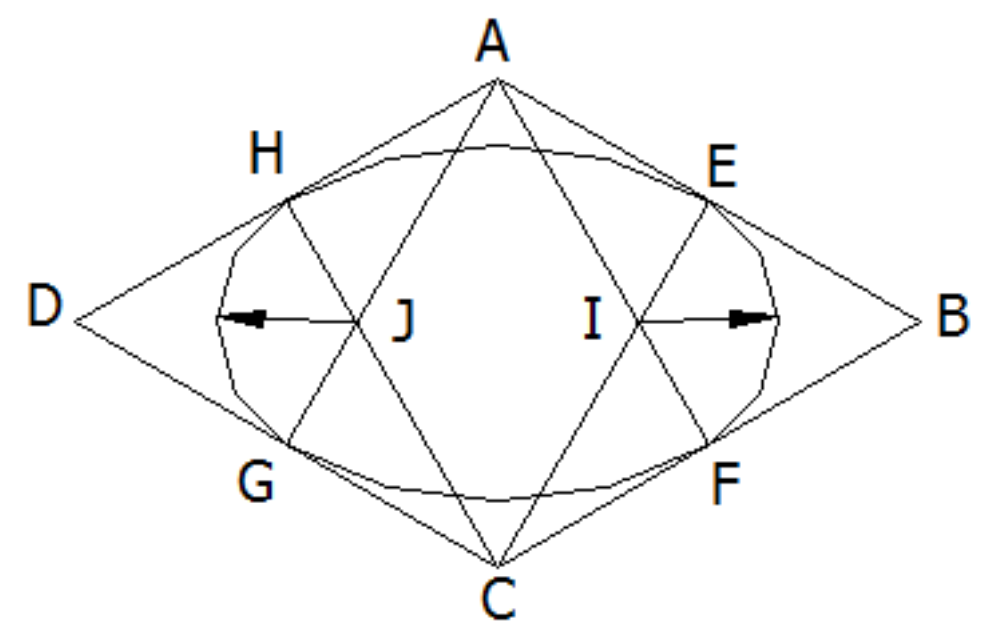

Obs: O que é importante salientar: antes de iniciar esses passos, deve-se achar o centro do furo e desenhar o quadrado isométrico.

O procedimento é o mesmo qualquer que seja o plano utilizado. Notem, na figura abaixo, os sentidos das elípses.

Figura - Representação da perspectiva isométrica de circunferências.

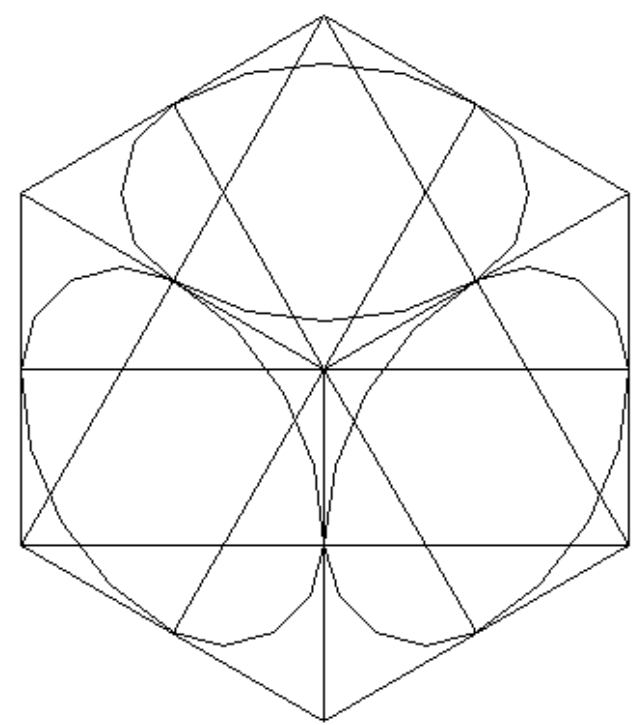




\section{EXERCÍCIO}

Represente o desenho em perspectiva isométrica em Escala 1:1. Lembre-se que para fazer o furo em perspectiva, é necessário antes fazer o quadrado isométrico com as arestas do tamanho do diâmetro do furo.
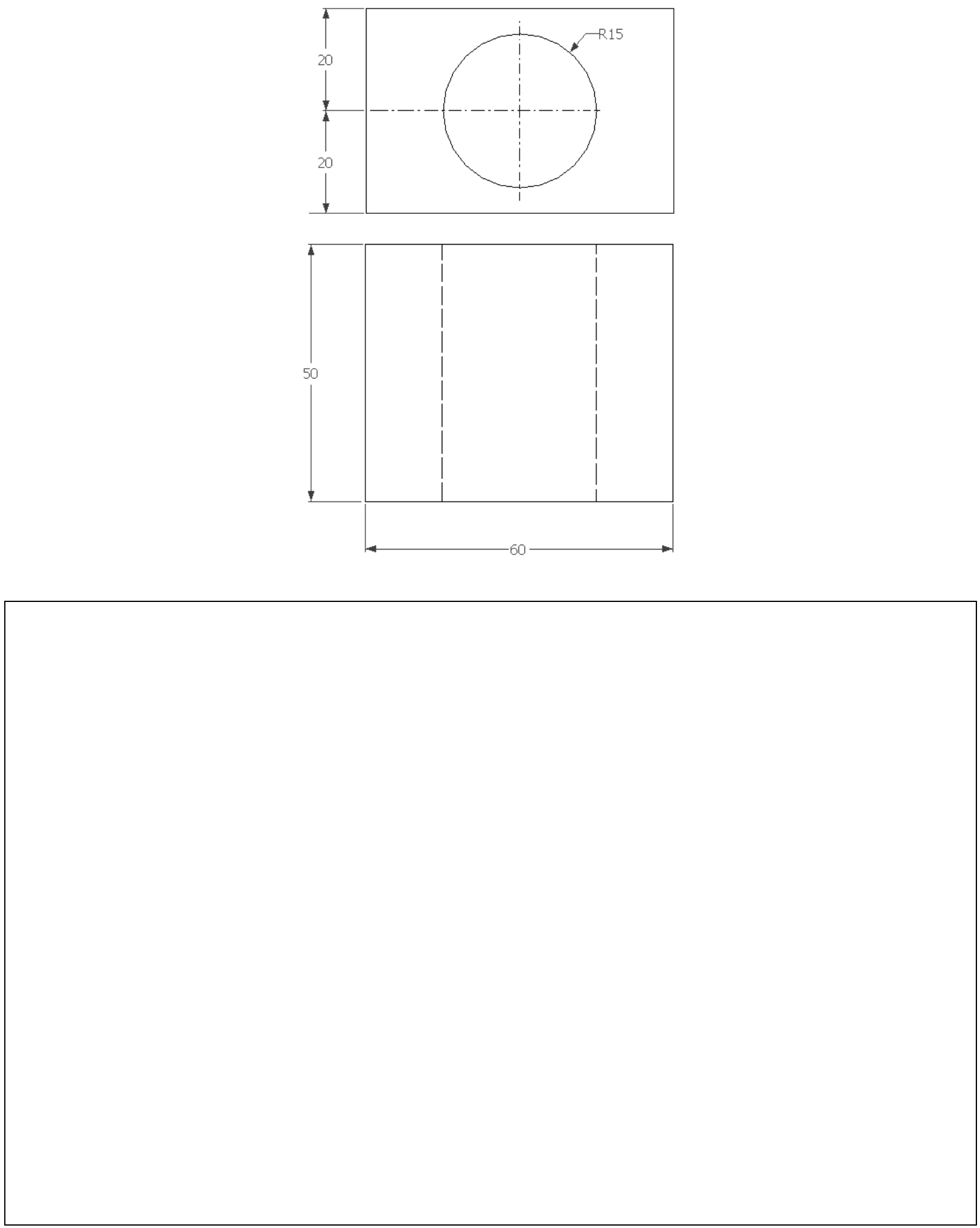


\section{CAPÍTULO 10}

\section{PERSPECTIVA ISOMÉTRICA DE MODELOS COM ELEMENTOS CIRCULARES E ARREDONDADOS}

Os modelos prismáticos com elementos circulares e arredondados também podem ser considerados como derivados do prisma.

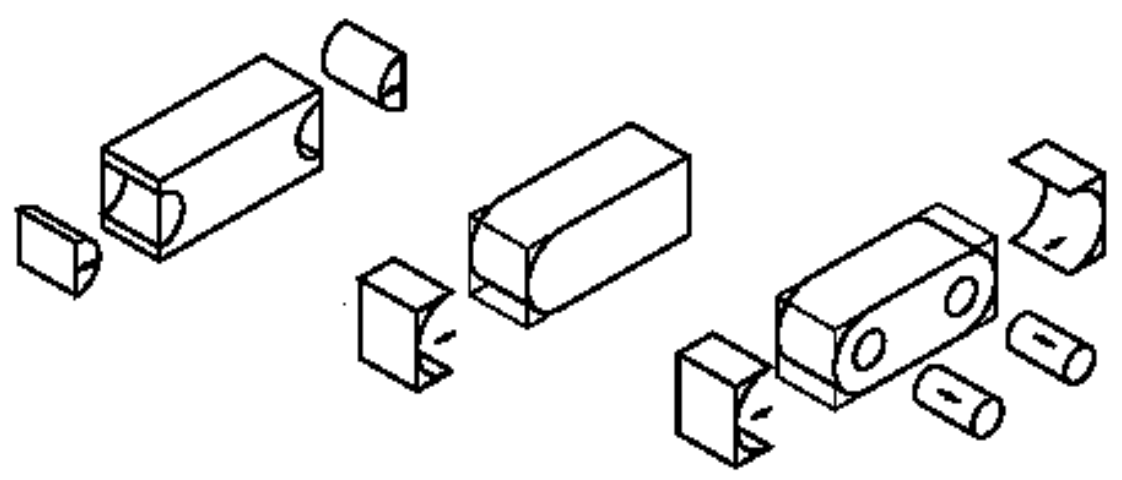

O traçado da perspectiva isométrica desses modelos também parte dos eixos isométricos e da representação de um prisma auxiliar, que servirá como elemento de construção.

O tamanho desse prisma depende do comprimento, da largura e da altura do modelo a ser representado em perspectiva isométrica. Mais uma vez, o traçado será demonstrado em cinco fases. Acompanhe atentamente cada uma delas e aproveite para praticar no reticulado da direita. Observe o modelo utilizado para ilustrar as fases. Os elementos arredondados que aparecem no modelo têm forma de semicírculo.

Para traçar a perspectiva isométrica de semicírculos, você precisa apenas da metade do quadrado auxiliar. 


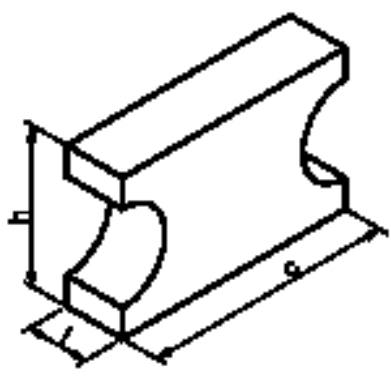

$1^{\circ}$ fase - Trace o prisma auxiliar respeitando - comprimento, a largura e a altura aproximados do prisma com elementos arredondados.

$2^{\circ}$ fase - Marque, na face anterior e na face posterior, os semiquadrados que auxiliam 0 traçado dos semicírculos.

$3^{\circ}$ fase - Trace os semicírculos que determinam os elementos arredondados, na face anterior e na face posterior do modelo.

$4^{\circ}$ fase - Complete o traçado das faces laterais.

$5^{\circ}$ fase - Apague as linhas de construção e reforce o contorno do traçado.
Prisma com

elementos arredondados

$\mathrm{c}=$ comprimento

I = largura

$\mathrm{h}=$ altura
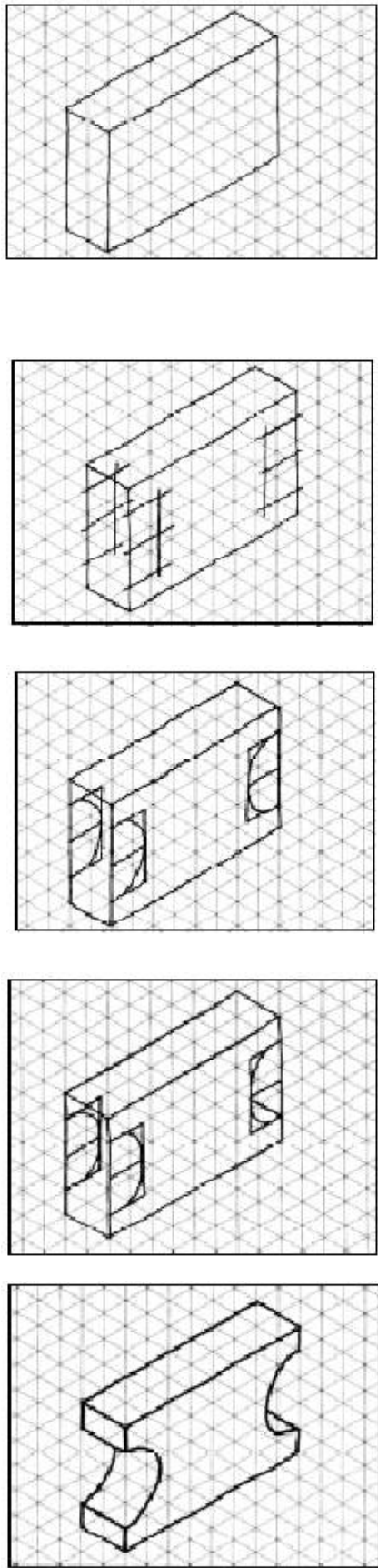


\section{CAPÍTULO 11}

\section{PERSPECTIVA ISOMÉTRICA DE MODELOS COM ELEMENTOS DIVERSOS}

Na prática, você encontrará peças e objetos que reúnem elementos diversos em um mesmo modelo. Veja alguns exemplos.
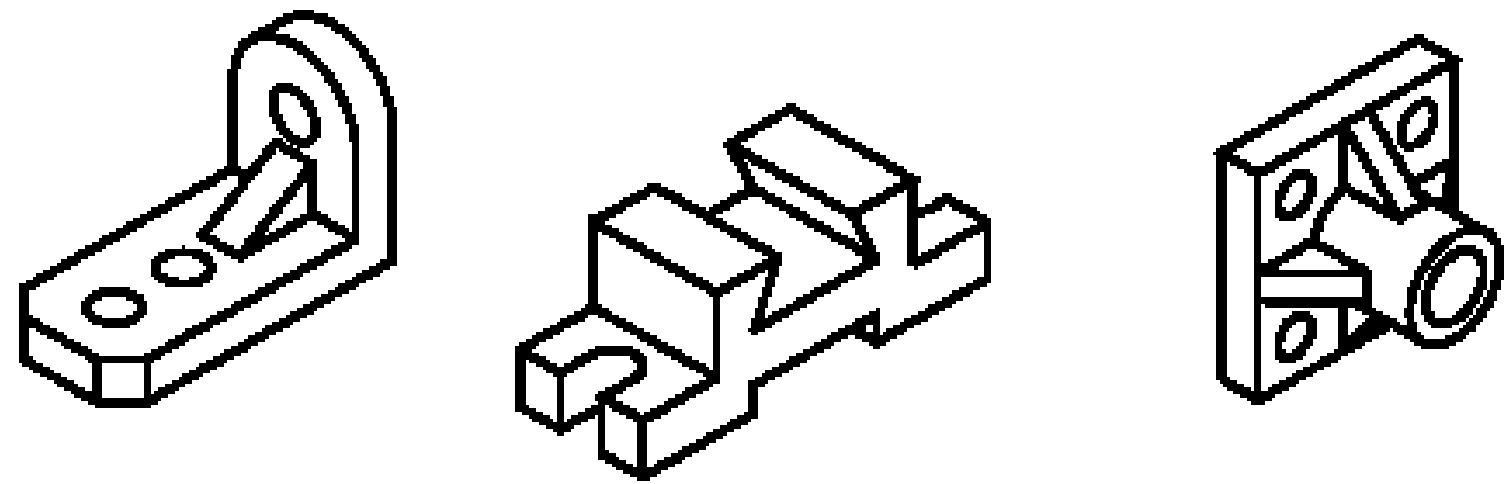

Os modelos acima apresentam chanfros, rebaixos, furos e rasgos. Com os conhecimentos que você já adquiriu sobre o traçado de perspectiva isométrica é possível representar qualquer modelo prismático com elementos variados.

Isso ocorre porque a perspectiva isométrica desses modelos parte sempre de um prisma auxiliar e obedece à seqüência de fases do traçado que você já conhece.

\section{VISUALIZAÇÃO DOS OBJETOS}

Os eixos isométricos poderão ocupar várias posições, de modo a representar o objeto de qualquer ângulo (Figura a seguir).

Figura - Posição dos eixos isométricos.
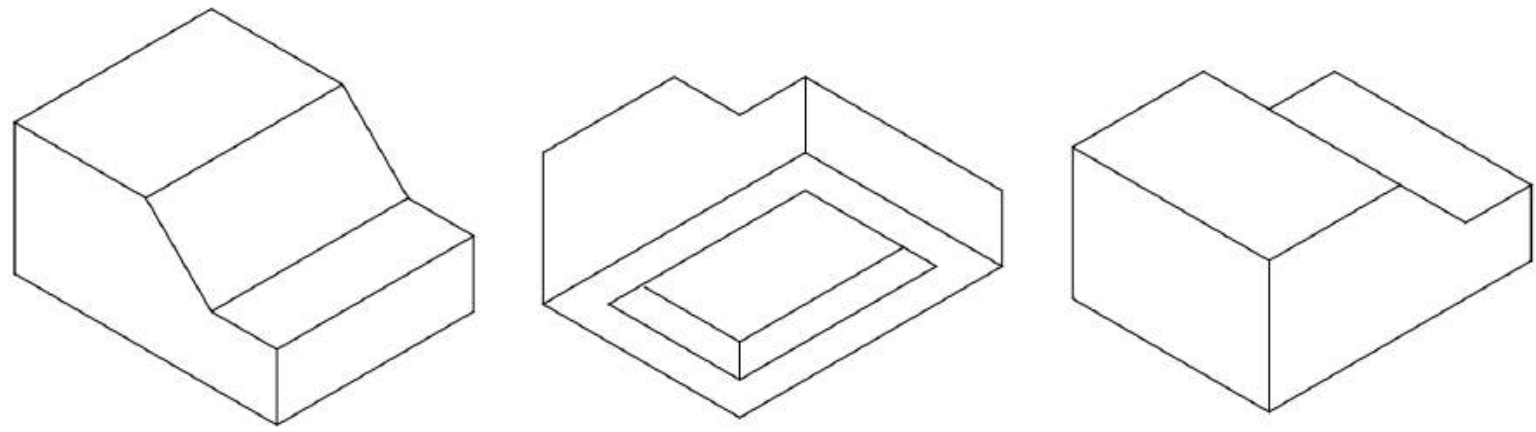
Figura - em forma de projeção ortogonal.
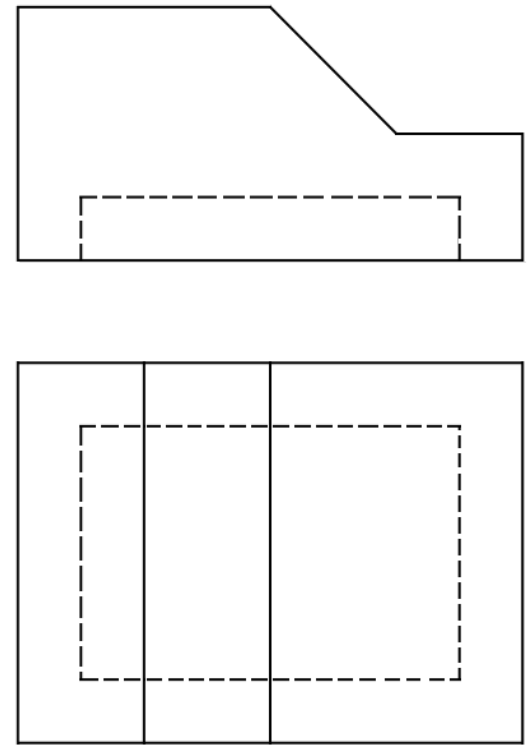

Não uma regra que determina quais eixos deve estar correlacionada para formar vista perspectiva isométrica. Por conveniência, usa-se a vista (posicionamento) que demonstra o maior número de detalhes da peça.

A seguir mostra como se deve iniciar qualquer desenho em Perspectiva Isométrica.

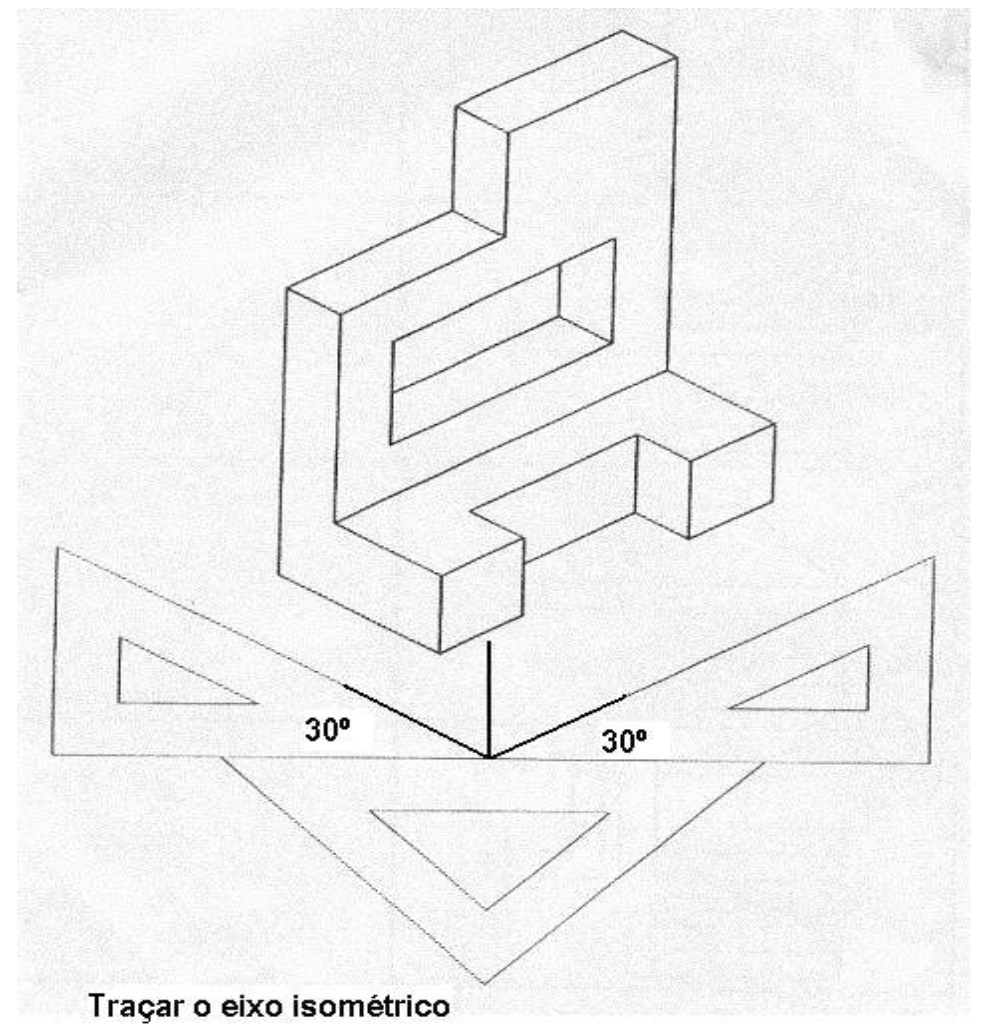




\section{EXERCÍCIOS DE PERSPECTIVA ISOMÉTRICA SIMPLIFICADA}

1) Construir a Perspectiva Isométrica das peças dadas.

a) Escala 2:1
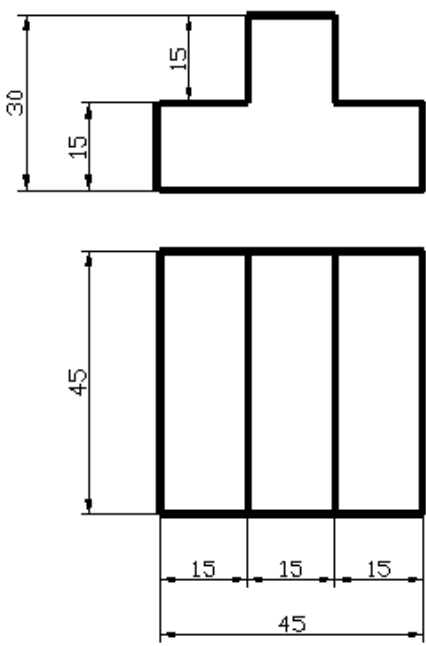

b) Escala 2:1
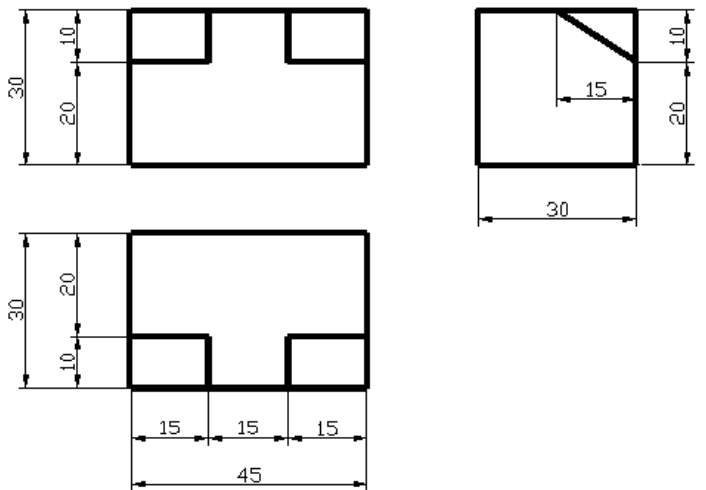

c) Escala 2:1
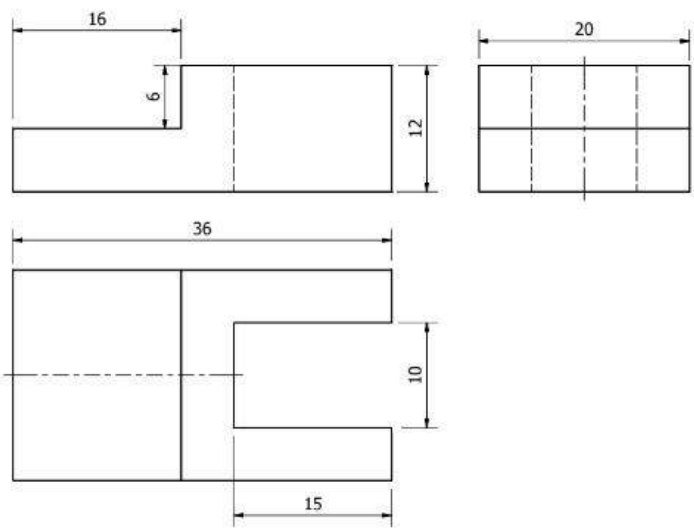

Catapan, Strobel e Santana (2020) 
d) Escala 1:1
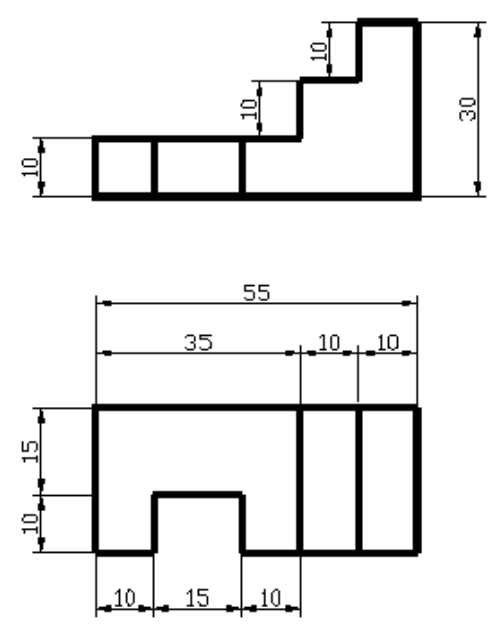

e) Esacala 2:1
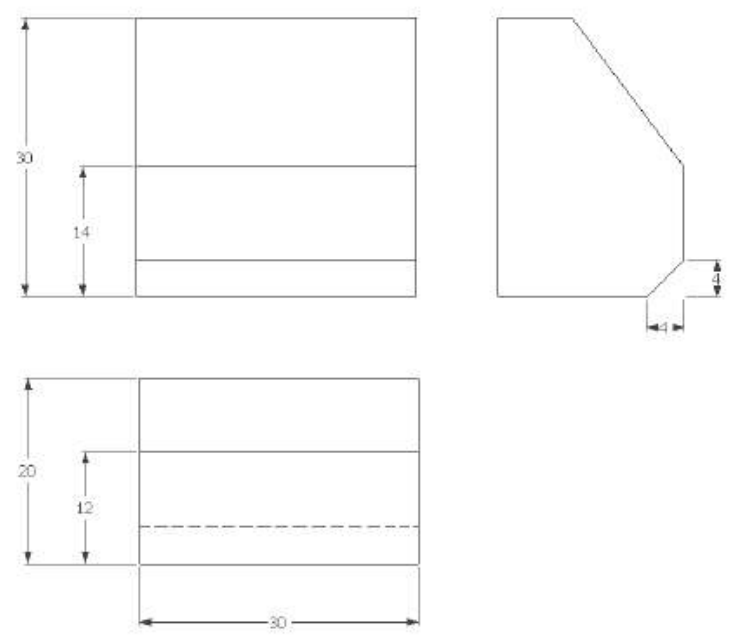

d) Escala 2:1
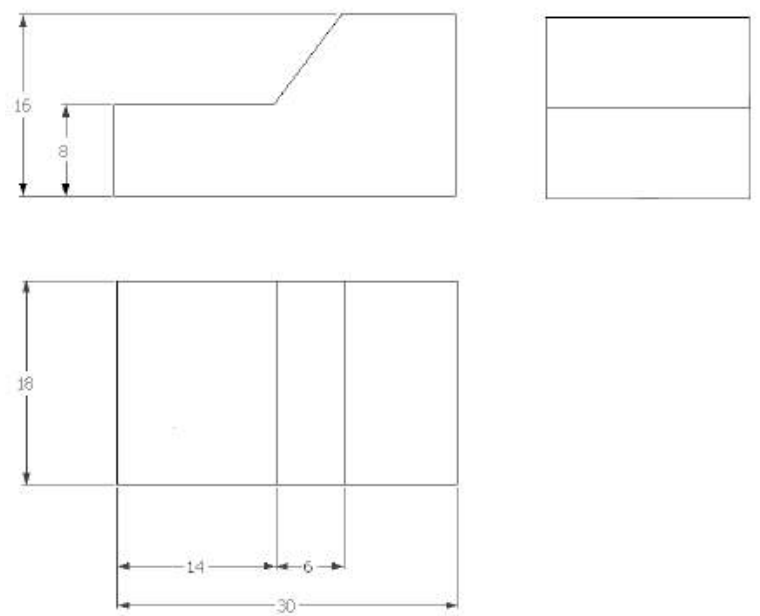
e) Escala 2:1
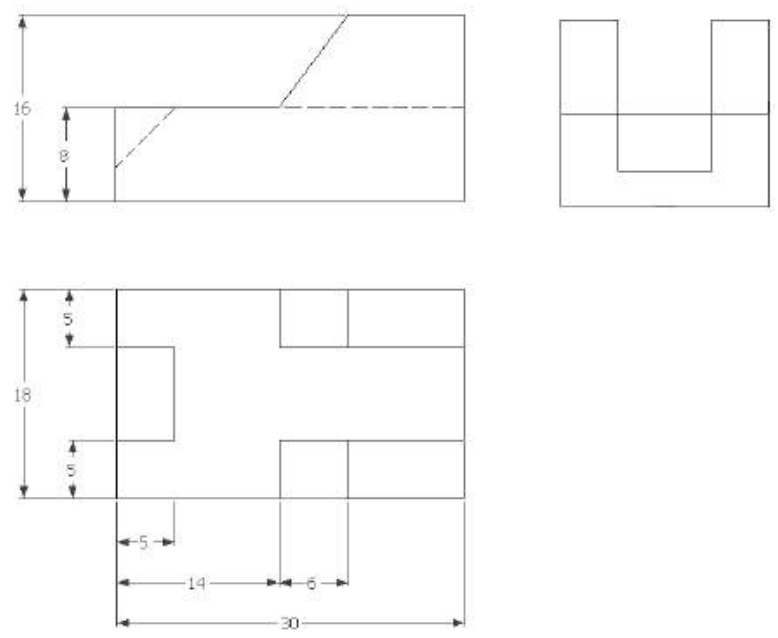

f) Escala 2:1
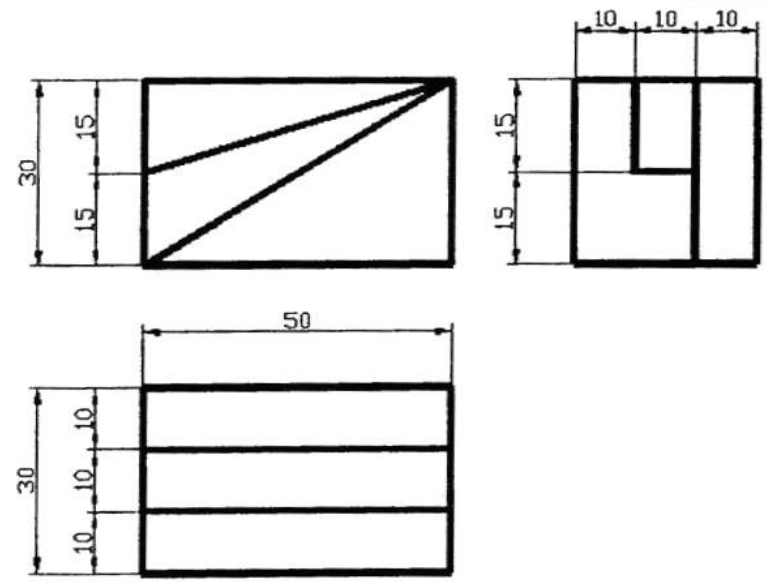

g) Escala 2:1
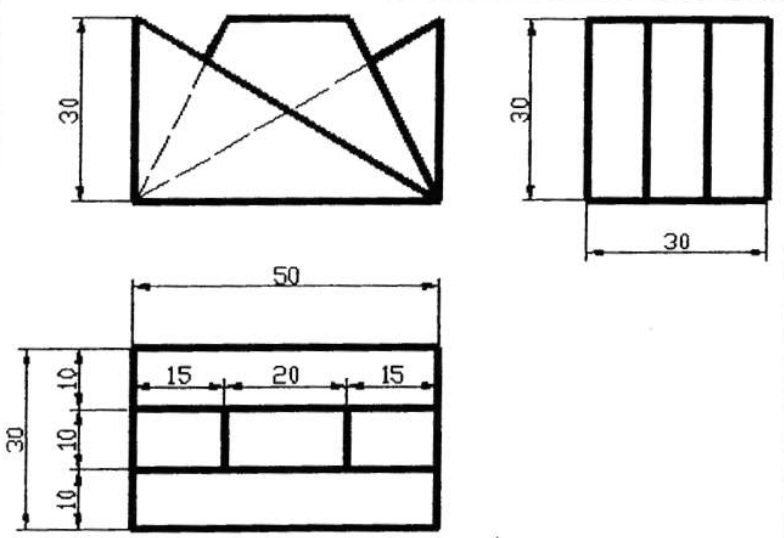
h) Escala 2:1
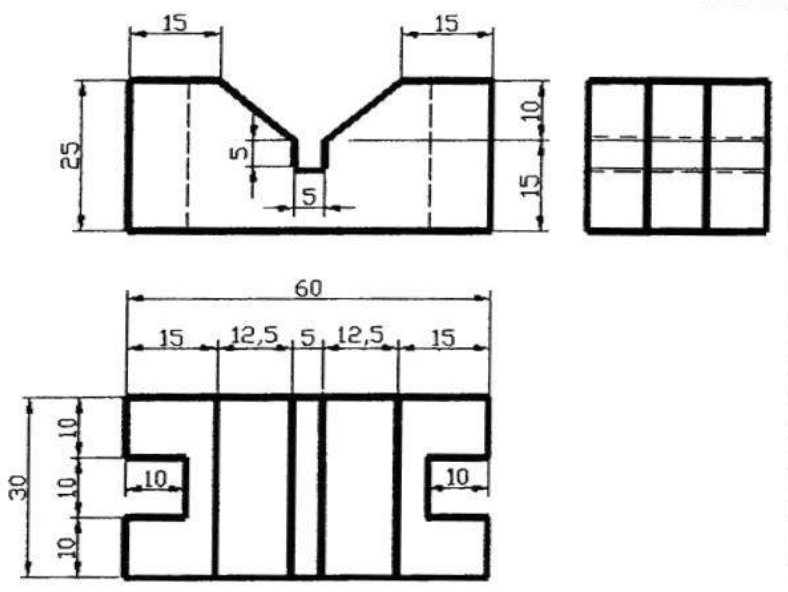

i) Escala 1:1
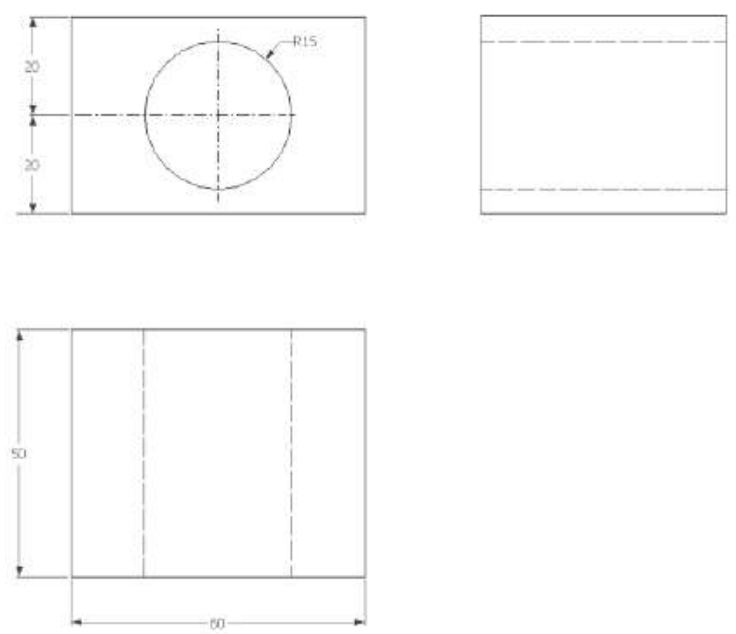

j) Escala 1:1

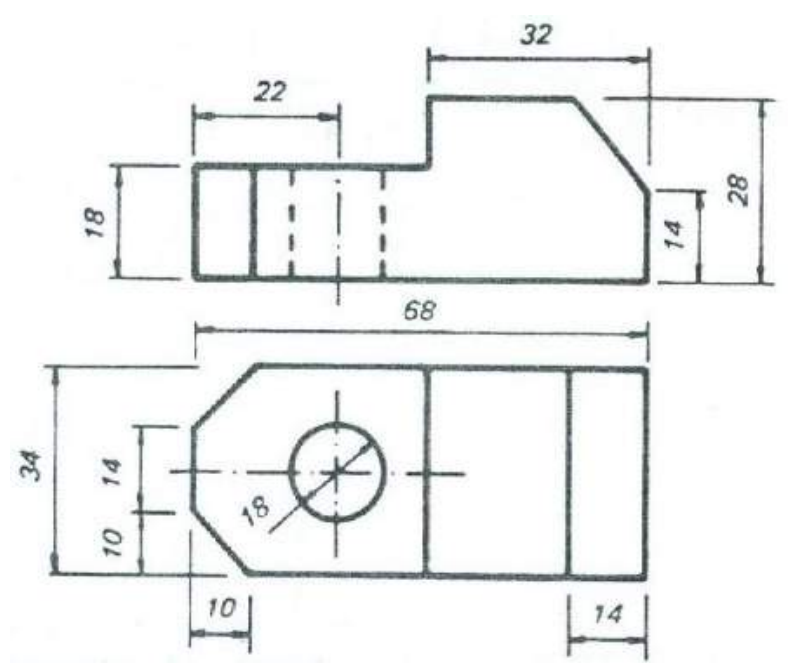

Catapan, Strobel e Santana (2020) 
k) Escala 1:1
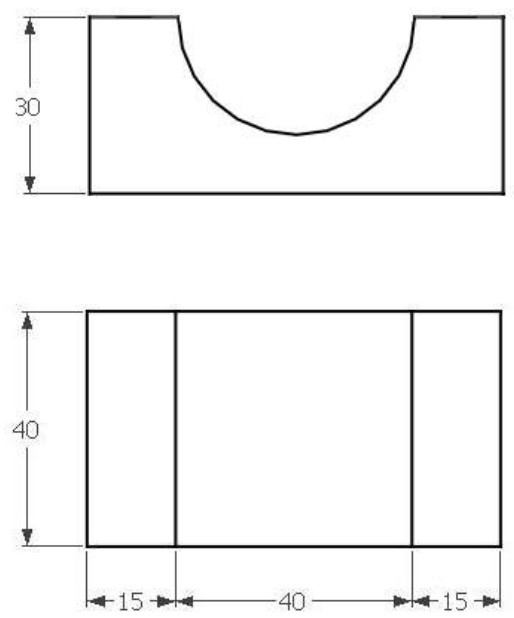

I) Escala 1:1

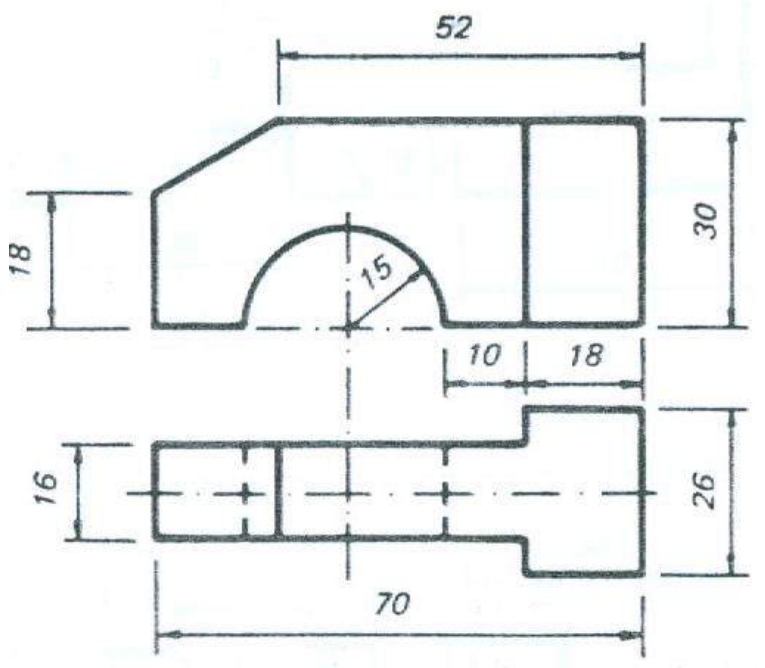

m) Escala 2:1

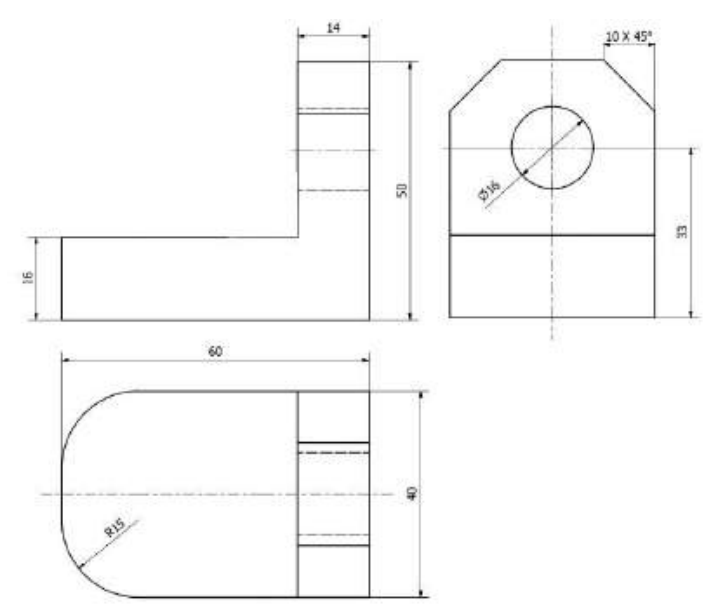




\section{CAPÍTULO 12}

\section{VISTAS AUXILIARES}

A Figura 12.1 mostra as três vistas principais de um objeto com superfície inclinada, pode-se observar que em nenhuma das três vistas aparece em verdadeira grandeza a parte inclinada do objeto.

Figura 12.1 - Vistas ortográficas de um objeto com superfície inclinada.

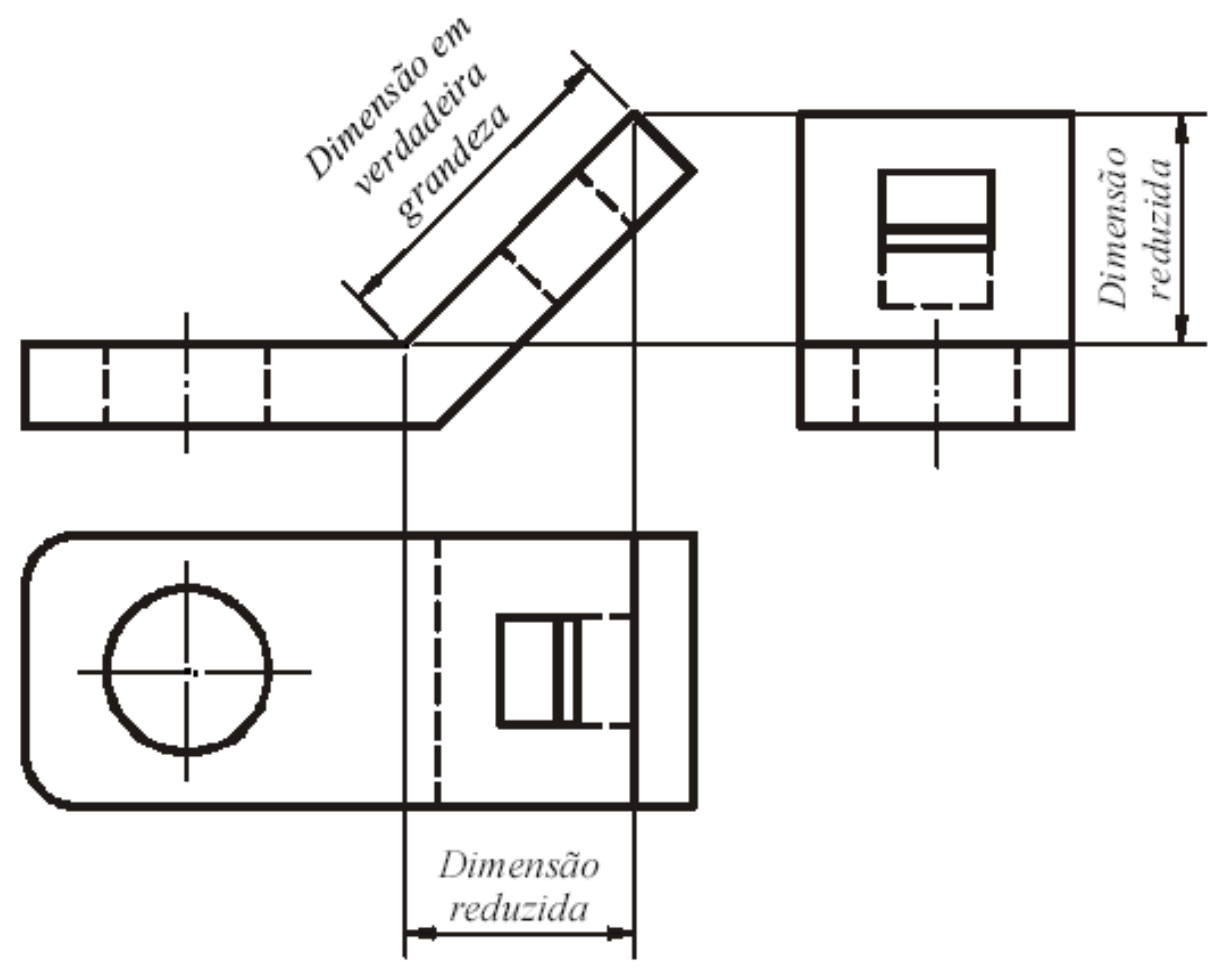

Fonte: http://www.eel.usp.br

A representação da verdadeira grandeza de uma superfície inclinada só será possível fazendo a sua projeção ortogonal em um plano paralelo à parte inclinada, como mostra a Figura 12.2. 
Figura 12.2 - Projeção ortogonal de um objeto num plano paralelo à superfície inclinada.

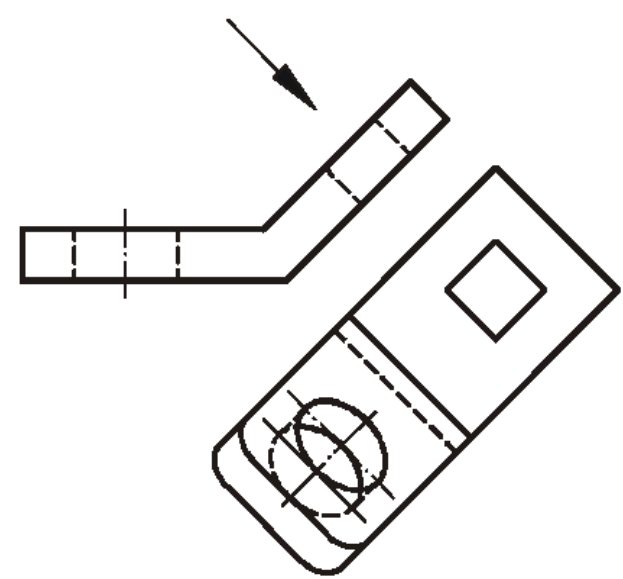

Fonte: http://www.eel.usp.br

A Figura 12.3 mostra um exemplo de uma peça que possui uma superfície inclinada e onde foi acrescentado um plano de projeção paralelo a essa face de modo a representá-la em verdadeira grandeza.

Figura 12.3 - Vista auxiliar de um objeto para identificar a VG de sua superfície inclinada.

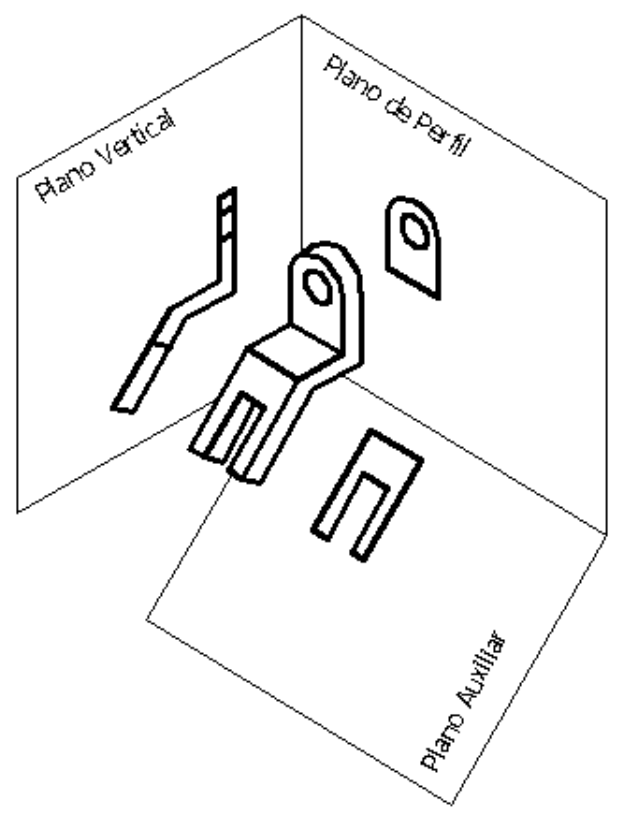

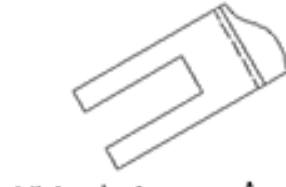

Vista de A

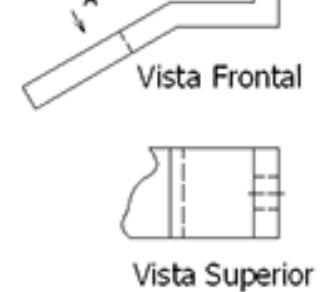

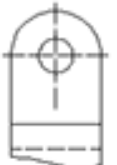

Vista Lat. Esq.

Como o desenho técnico tem como objetivo representar com clareza as formas espaciais dos objetos, não tem sentido prático desenhar as partes das vistas que aparecem com dimensões fora das suas verdadeiras grandezas. Desta forma, a ABNT recomenda a utilização de vistas parciais, limitadas por linhas de rupturas, 
que representam somente as partes que aparecem as formas verdadeiras dos objetos, conforme mostram as Figuras 12.3 e 12.4 .

Figura 12.4 - Utilização de vistas parciais em vistas auxiliares.

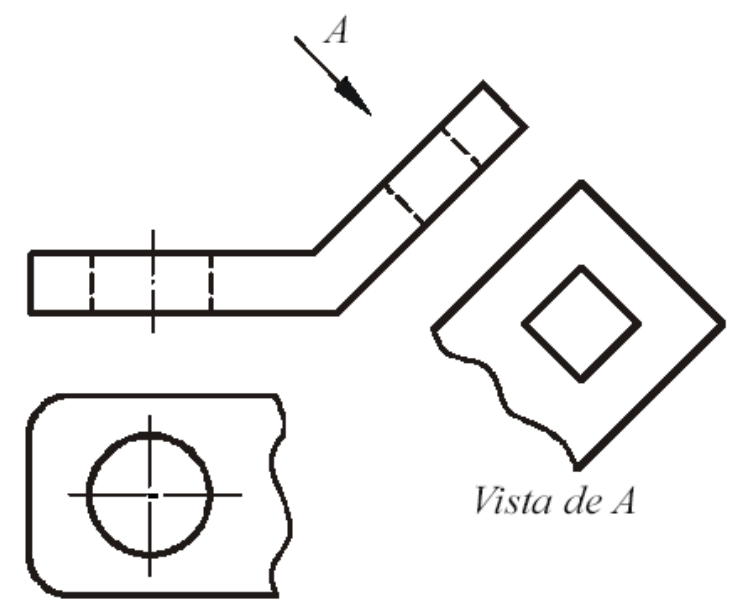

Fonte: http://www.eel.usp.br

As vistas auxiliares, como são localizadas em posições diferentes das posições resultantes das vistas principais, devem ter o sentido de observação indicado por uma seta designada por uma letra, que será usada para identificar a vista resultante daquela direção.

A Figura 12.5 mostra que as vistas auxiliares, além de representarem a forma do objeto com maior clareza, permitem que as cotas sejam referenciadas em verdadeiras grandezas nas dimensões cotadas.

Figura 12.5 - Cotagem em vistas auxiliares.

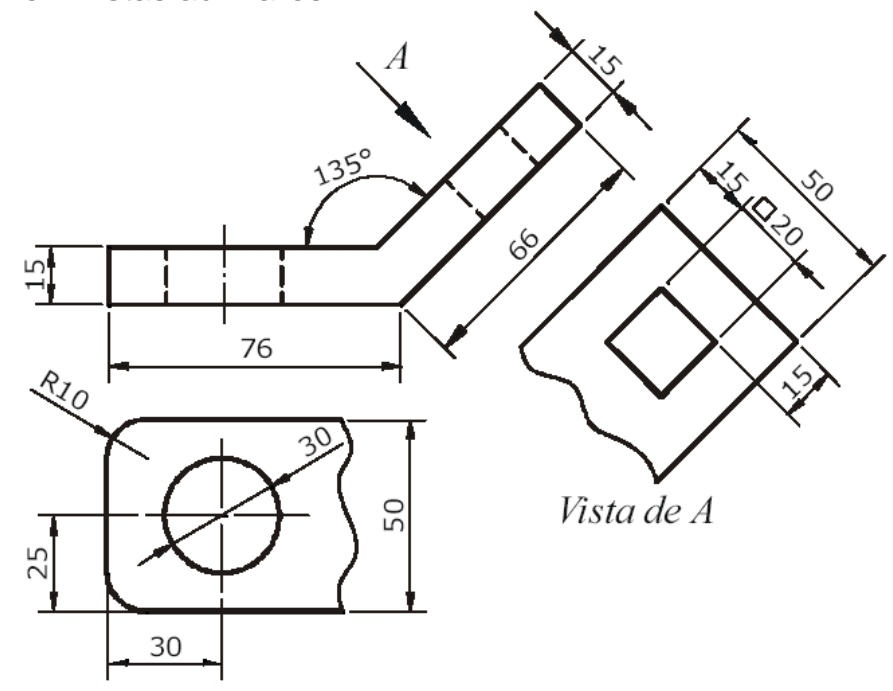

Fonte: http://www.eel.usp.br 
Na Figura 12.6 são mostradas duas representações. Na primeira, (Figura 12.6a) o objeto está representado por meio de suas vistas frontal, superior, lateral esquerda e lateral direita, não sendo possível representar a verdadeira grandeza de alguns detalhes da peça. E na segunda (Figura 12.6b) são utilizados planos auxiliares de projeção paralelos a estes detalhes, de modo a representá-los em sua verdadeira grandeza. Portanto, a maneira correta de representar o objeto da Figura 12.6 é utilizando a segunda forma.

Figura 12.6 - Representação desaconselhável (esquerda) e correta (direita) fazendo uso de planos auxiliares de projeção (vistas auxiliares).
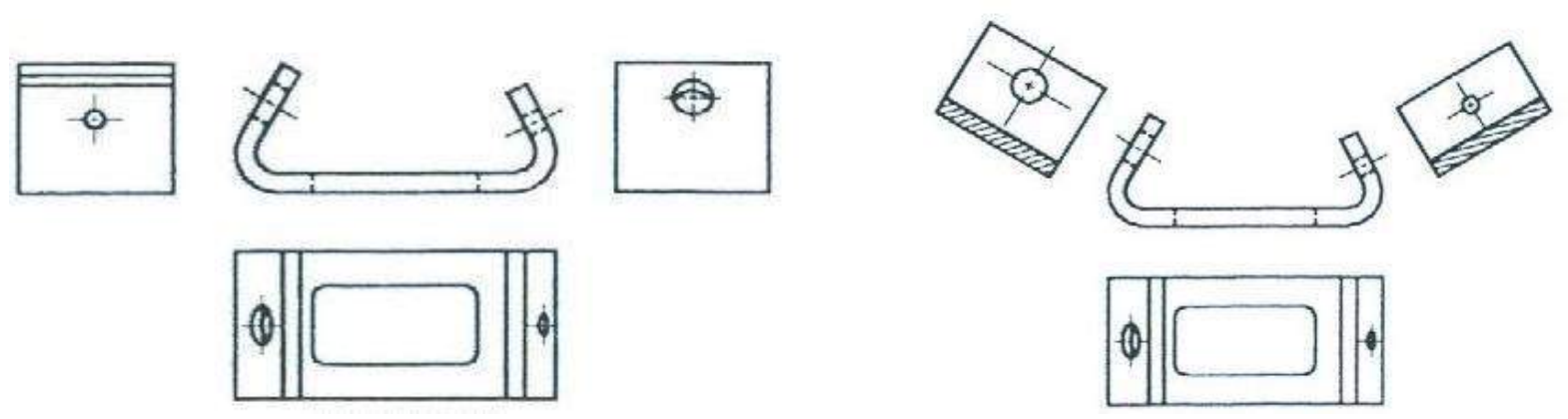

\section{EXERCÍCIOS DE VISTAS AUXILIARES}

1) Representar o objeto por meio da vista frontal (VF), da vista superior parcial (VSP) e da vista auxiliar (VA) do detalhe inclinado.

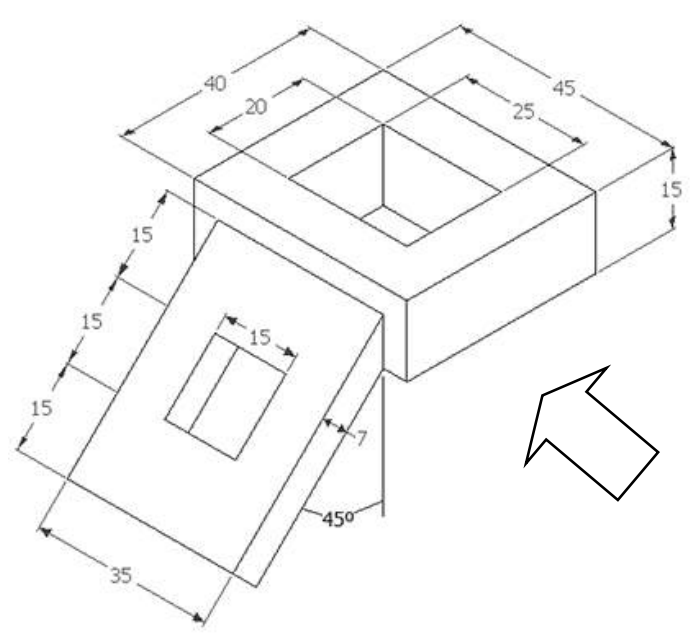


2) Representar o objeto por meio da vista frontal (VF), e de vistas auxiliares 1 e 2 (VA1 e VA2) dos detalhes inclinados.

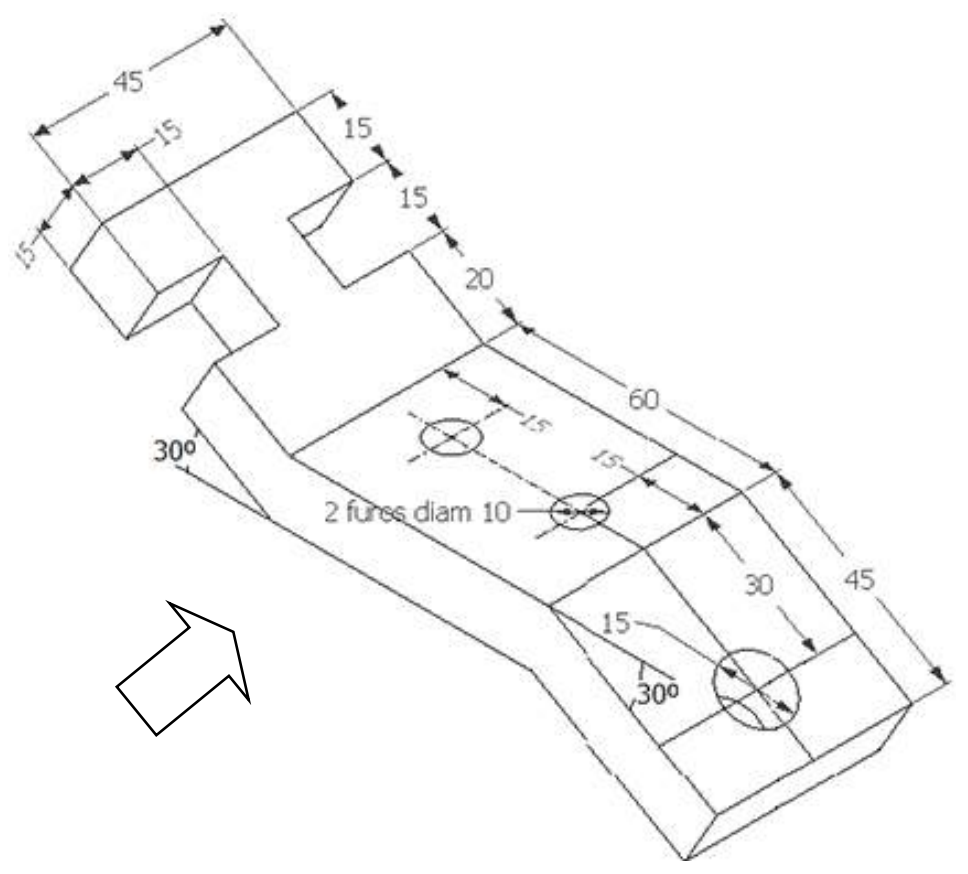

3) Representar o objeto por meio da vista frontal (VF), vista superior (VS), e de uma vista auxiliar dos detalhes inclinados.

a)

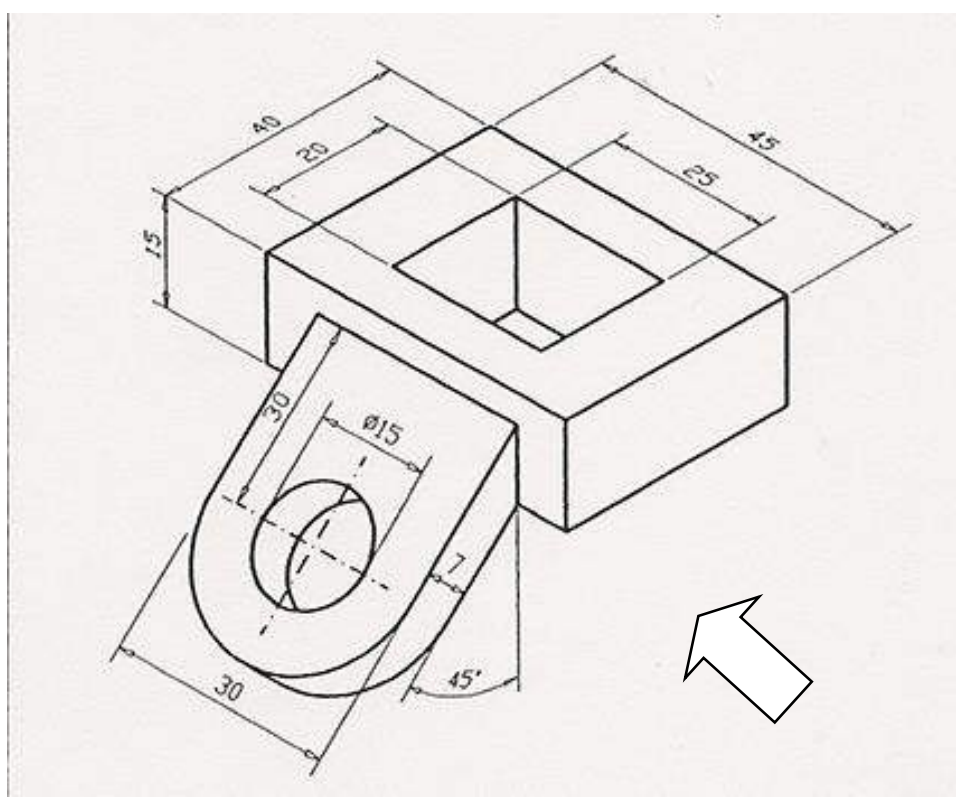


b)

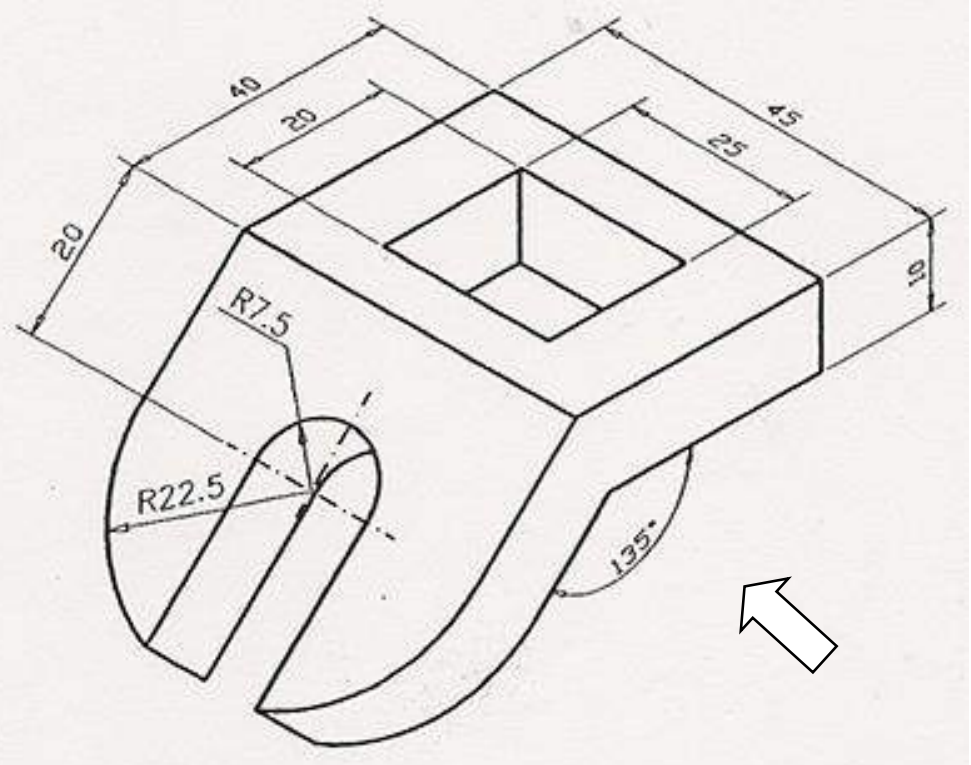


4) Representar o objeto por meio da vista frontal (VF), vista superior (VS), e de vistas auxiliares 1 e 2 (VA1 e VA2) dos detalhes inclinados.

a)

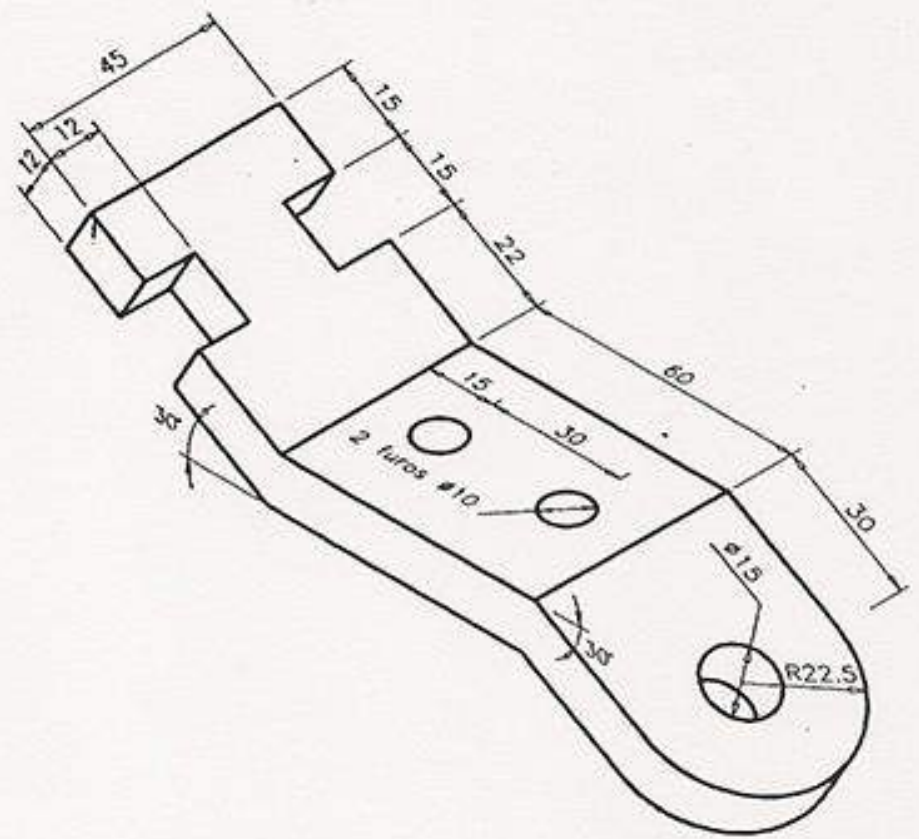


b)

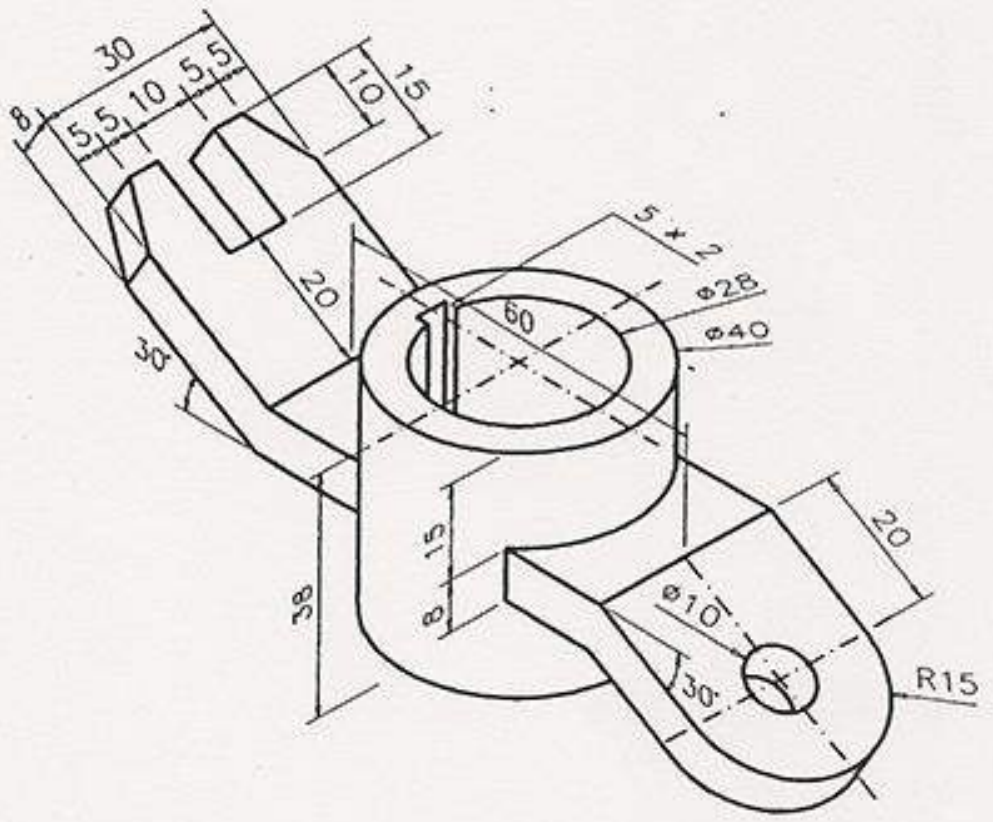




\section{CAPÍTULO 13}

\section{CORTE}

Significa divisão, separação. Em desenho técnico, o corte de uma peça é sempre imaginário. Ele permite ver as partes internas da peça.
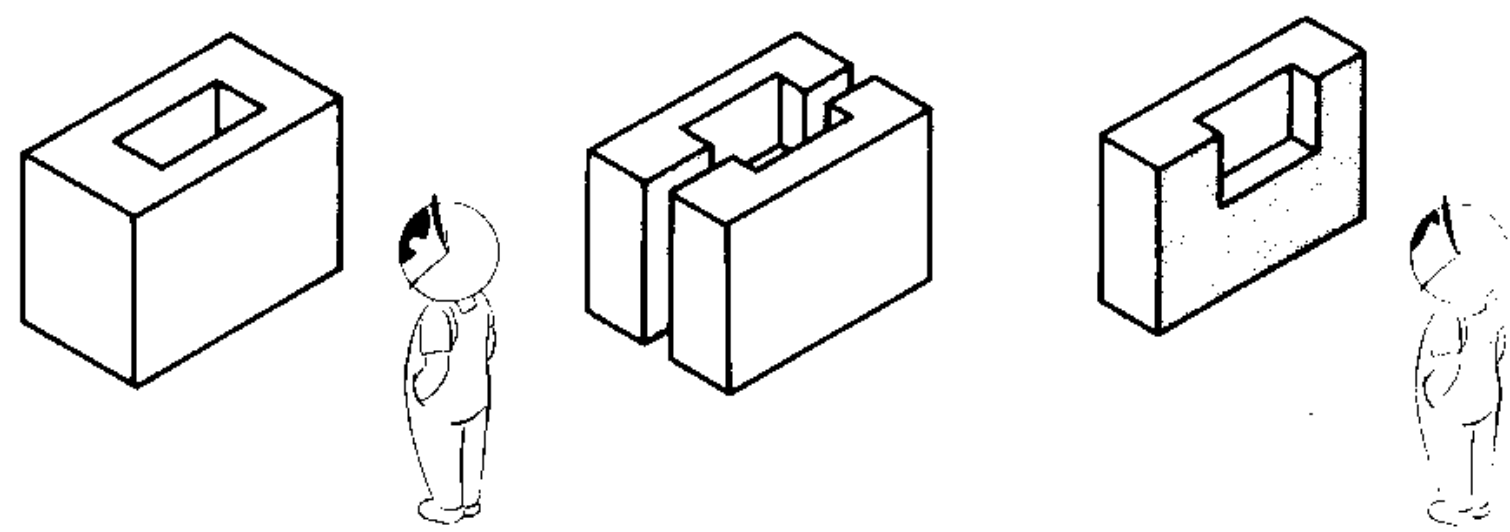

\subsection{HACHURA}

$\mathrm{Na}$ posição em corte, a superfície imaginada cortada é preenchida com hachuras. Elas são linhas estreitas que, além de representarem a superfície imaginada cortada, mostram também os tipos de materiais.

Figura 13.1. Maneira mais apropriada de representar hachura.

\section{hachuras}

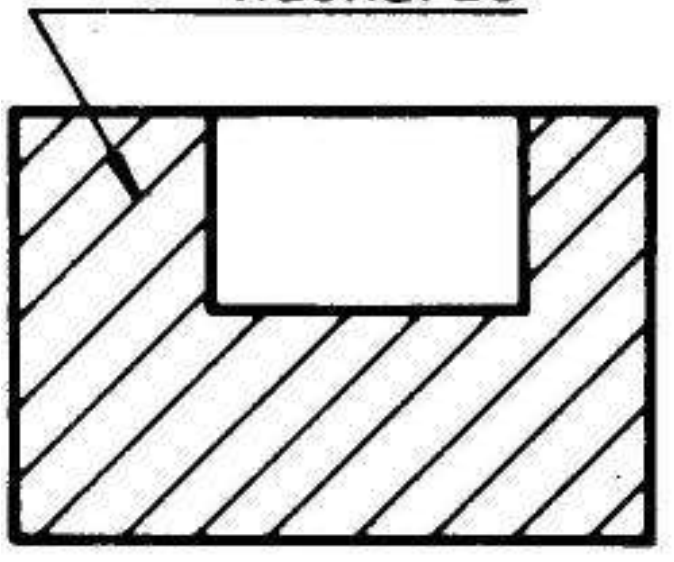


Figura 13.2. Hachuras para diferentes materiais (NBR 12298).
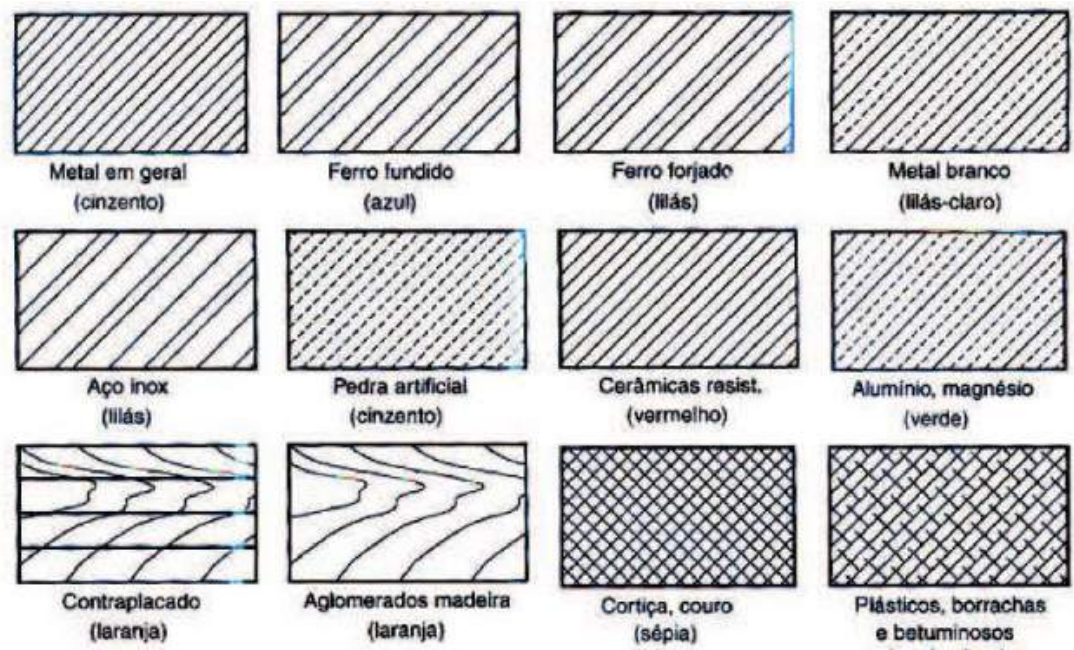

(azul)

(iilás)

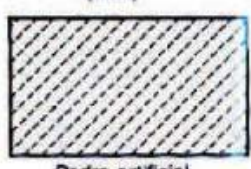

Pedra artificial

(cinzento)

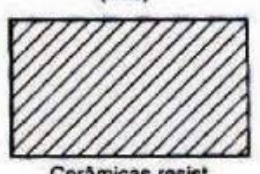

Cerâmicas rasis:

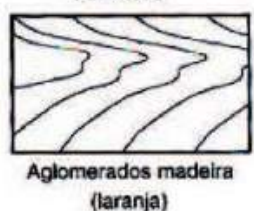

(vermelho)

Metal branco

(iliás-ciaro)
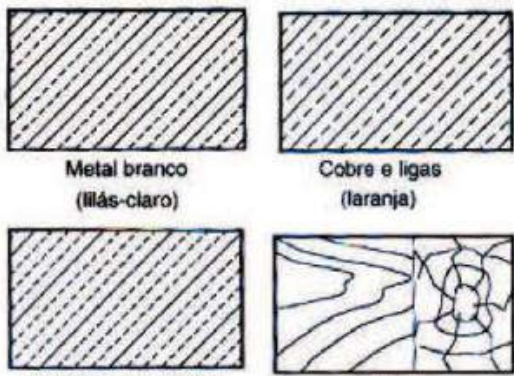

Aluminio, magnésio

(verde)
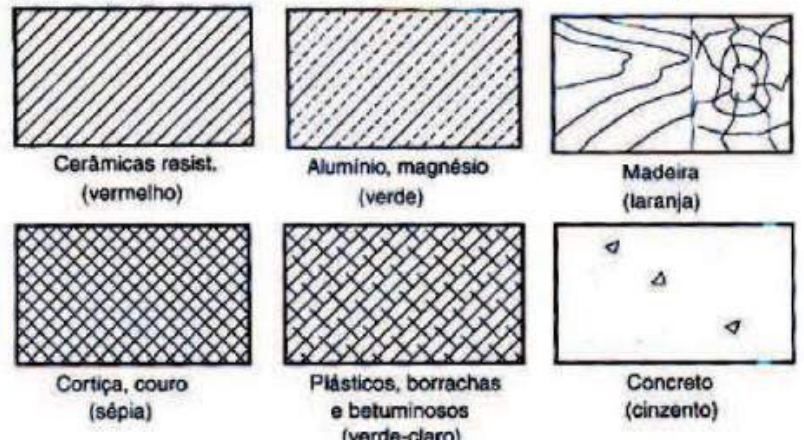

(laranja)

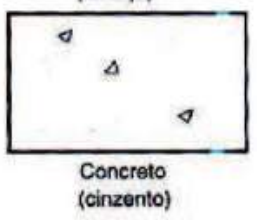

(sépia)

Segundo a NBR 12298, as Hachuras são formadas por linhas inclinadas a 45을 em relação às linhas principais do contorno ou eixos de simetria.

Figura 13.3. Representação da hachura a $45^{\circ}$.
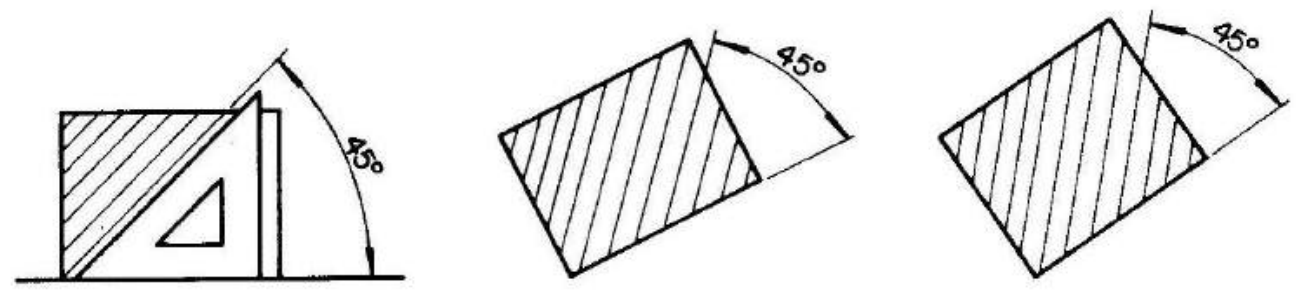

Contudo, deverá ser evitada a aplicação de uma direção paralela à de alguma aresta contida na envolvente da seção.

Figura 13.4. Exemplos de hachura diferente de $45^{\circ}$.
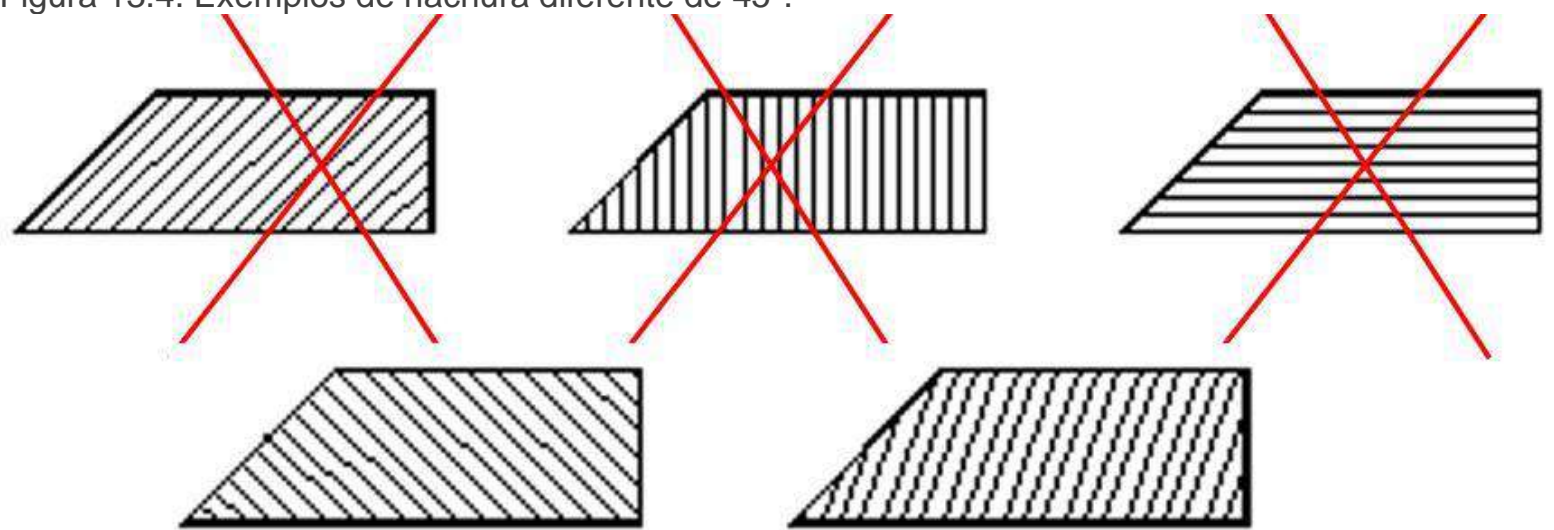

Catapan, Strobel e Santana (2020) 
Em caso de peças montadas, onde é necessário a diferenciação das hachuras para a identificação de peças, essas devem figurar com hachuras diferindo pela direção (angulação) ou pelo espaçamento.

Figura 13.5. Exemplos de hachura em peças montadas.

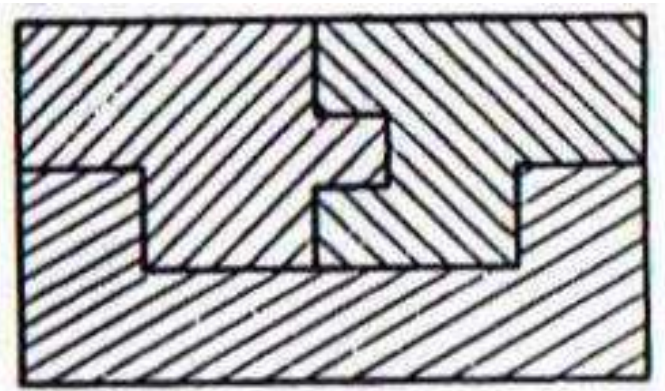

menos oconsethóvel

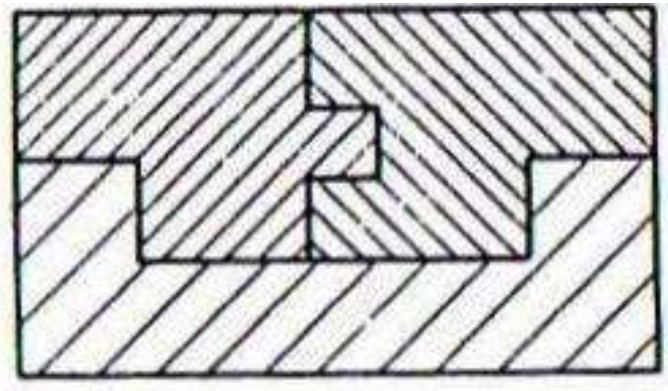

mois oconselhóvel

É importante destacar que as linhas que representam as arestas não visíveis, não precisam ser representadas nas vistas de cortes em alguns casos, principalmente se essas estão na mesma área onde das hachuras.

Figura 13.6. Exemplos de representações de linhas não visíveis em vistas de corte.

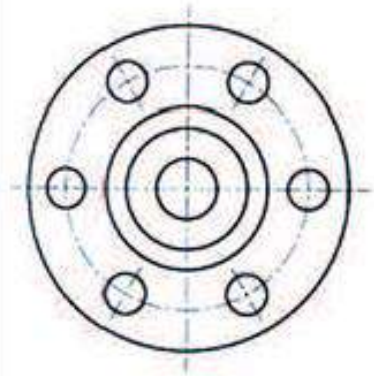

Certo
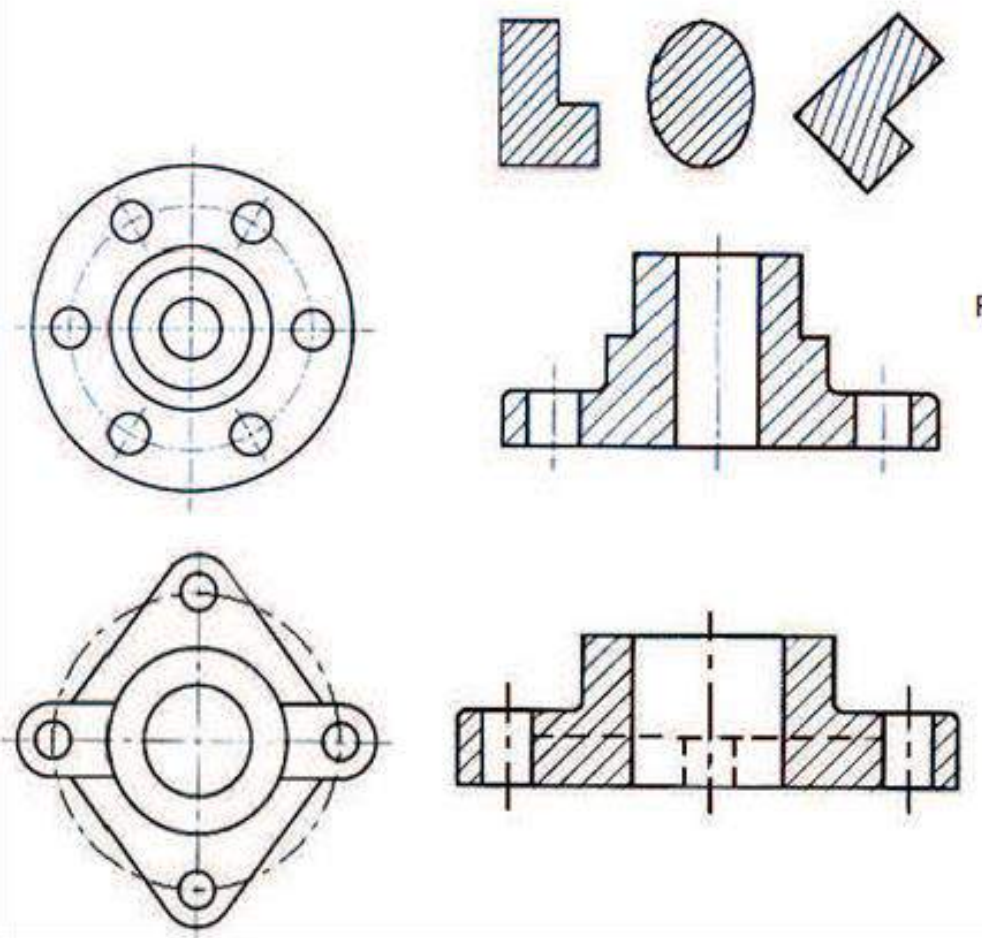

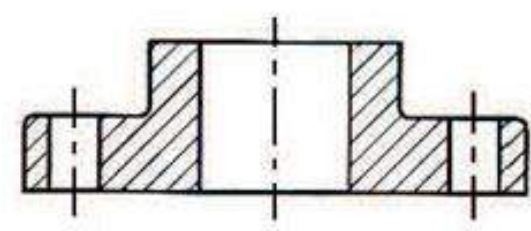

Errado
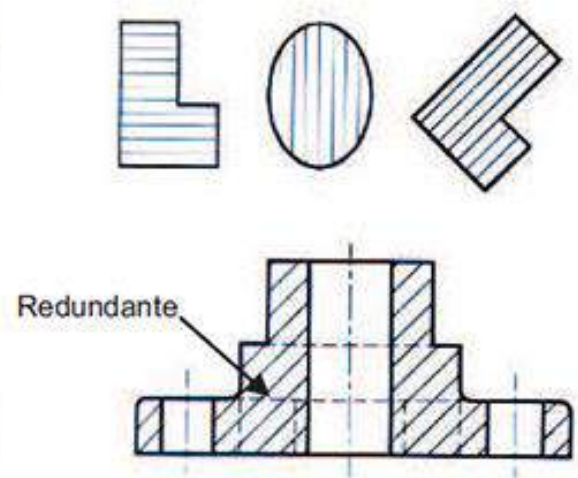


\section{QUANDO DEVEMOS USAR?}

Elevação frontal (interpretação confusa)

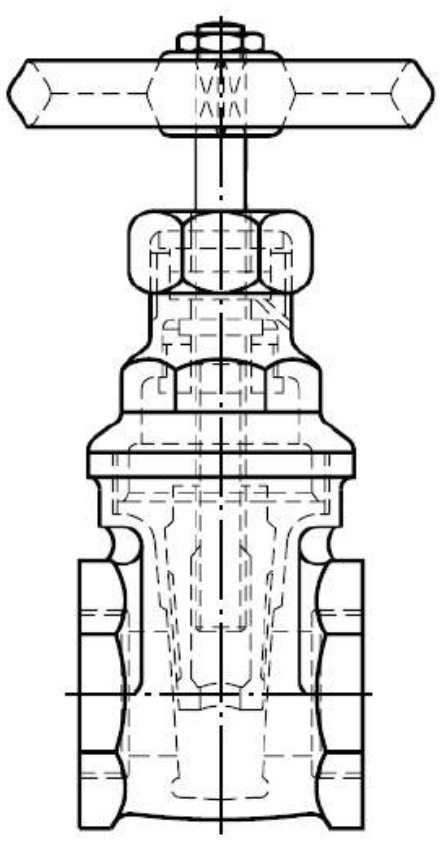

Corte total (melhor interpretação da montagem)

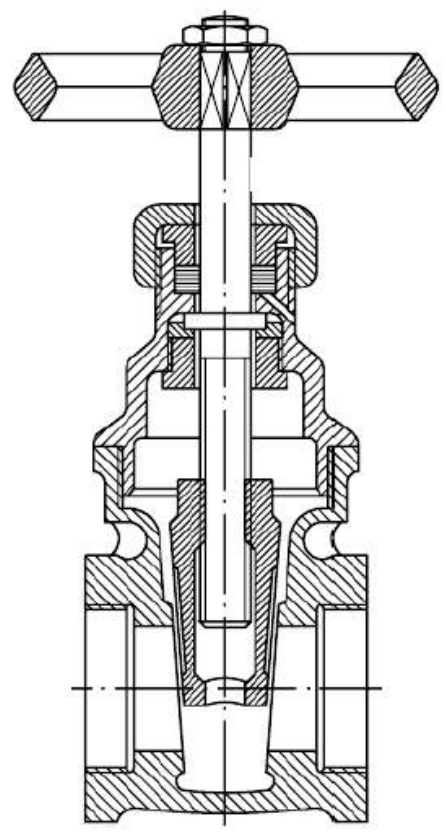

\subsection{EXEMPLOS DE CORTES}

As Figuras 13.7, 13.8 e 13.9 apresentam cortes nas vistas frontal, superior e lateral esquerda, respectivamente. A disposição dos cortes segue a mesma disposição das vistas ortográficas.

Figura 13.7 - Corte realizado na vista frontal.
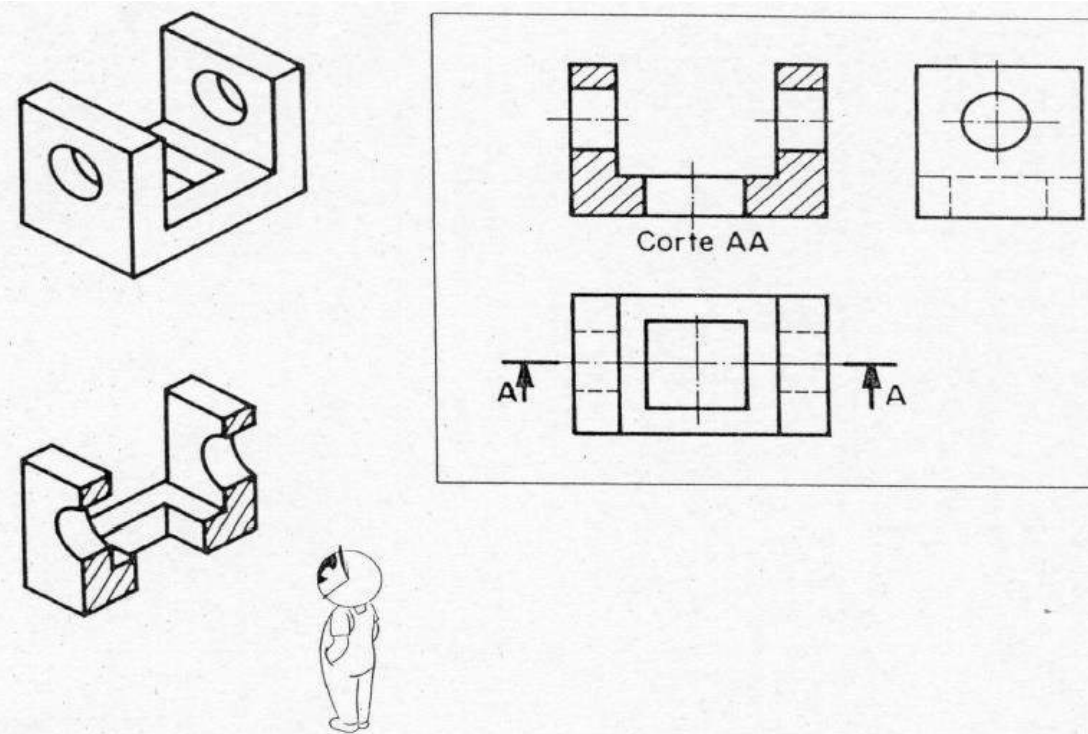

Fonte: Rosado, V. O. G., 2005.

Catapan, Strobel e Santana (2020) 
Figura 13.8 - Corte realizado na vista superior.
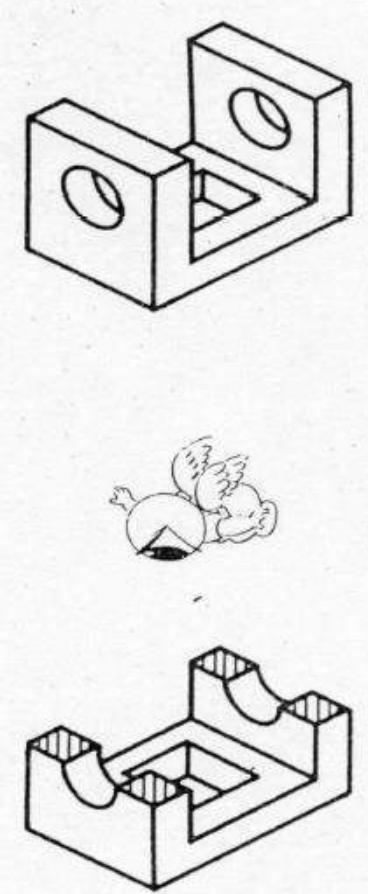
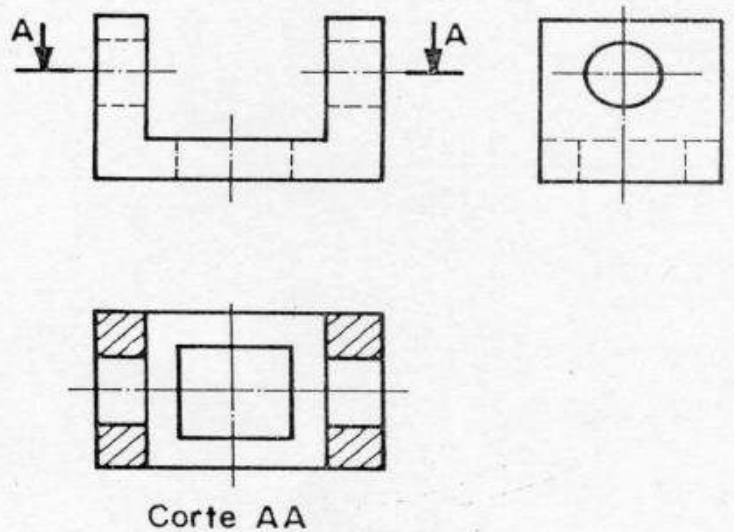

Fonte: Rosado, V. O. G., 2005.

Figura 13.9 - Corte realizado na vista lateral esquerda.
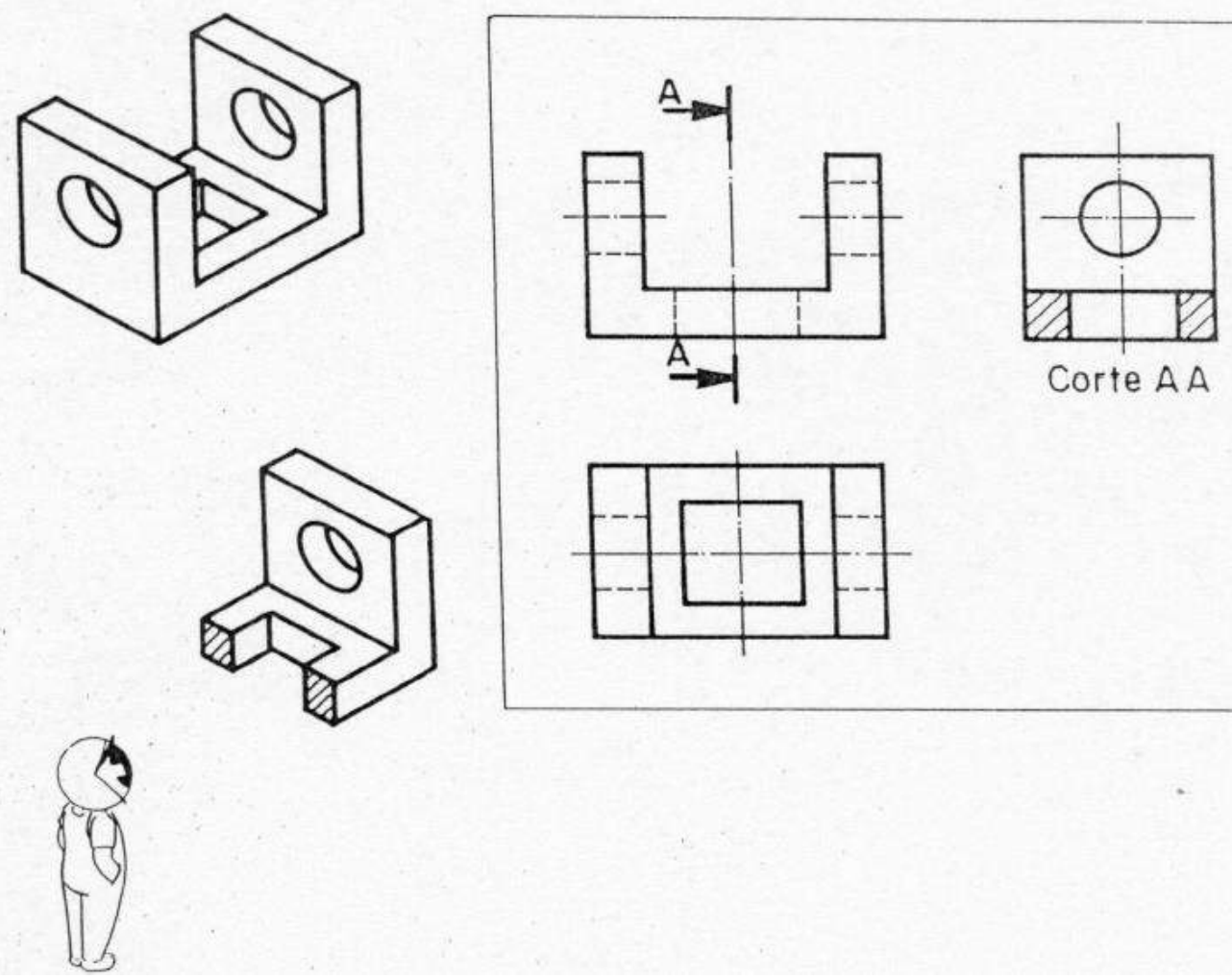

Fonte: Rosado, V. O. G., 2005. 
Na Figura 13.10 se observa duas das vistas principais que foram substituídas pelos cortes.

Figura 13.10 - Cortes realizados nas vistas frontal e lateral esquerda.
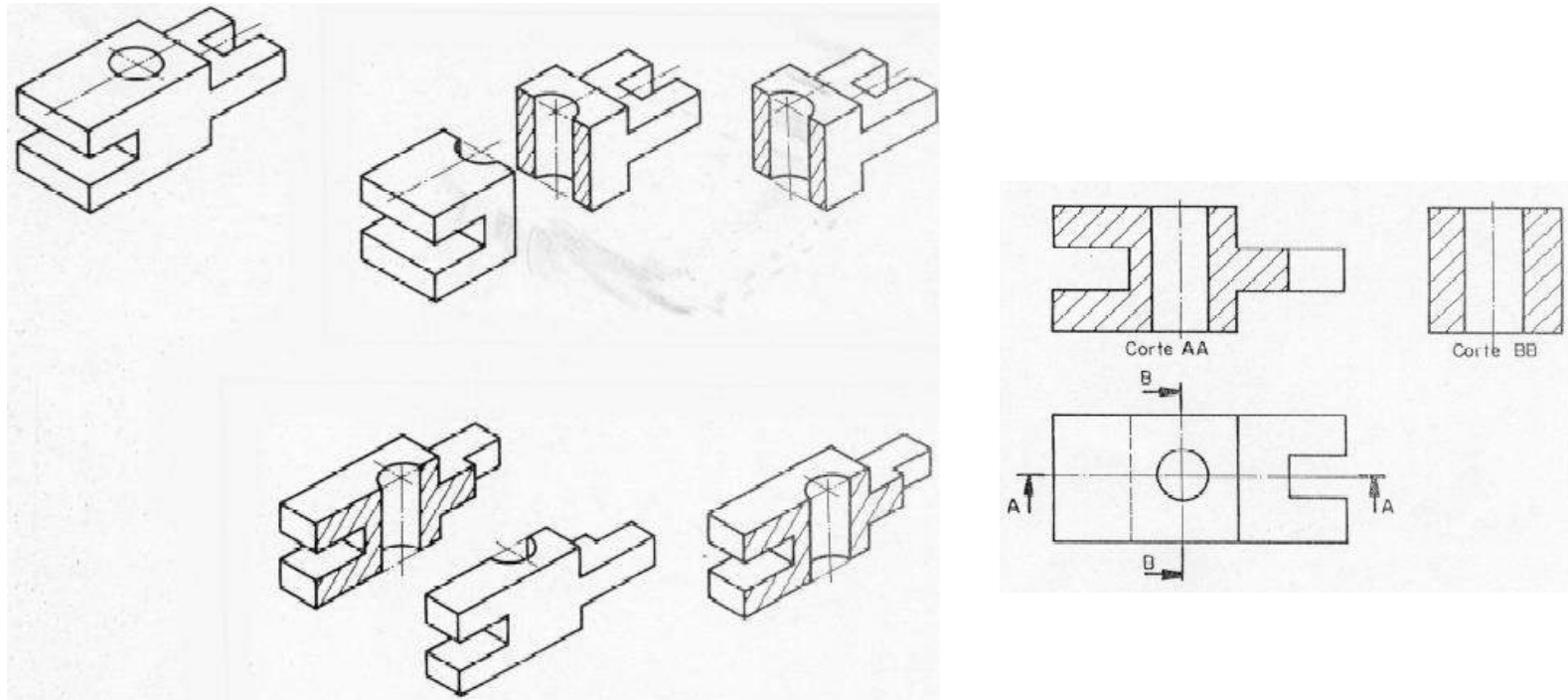

Fonte: Rosado, V. O. G., 2005.

\subsection{TIPOS DE CORTES}

Corte pleno ou total: O objeto é cortado em toda a sua extensão. Normalmente o plano passa pelo eixo principal (Figura 13.11a).

Meio-corte: É utilizado no desenho de peças simétricas, onde metade aparece em corte e a outra metade aparece em vista externa (Figura 13.11b).

Figura 13.11 - Tipos de cortes: a) Corte pleno ou total; b) Meio-corte.
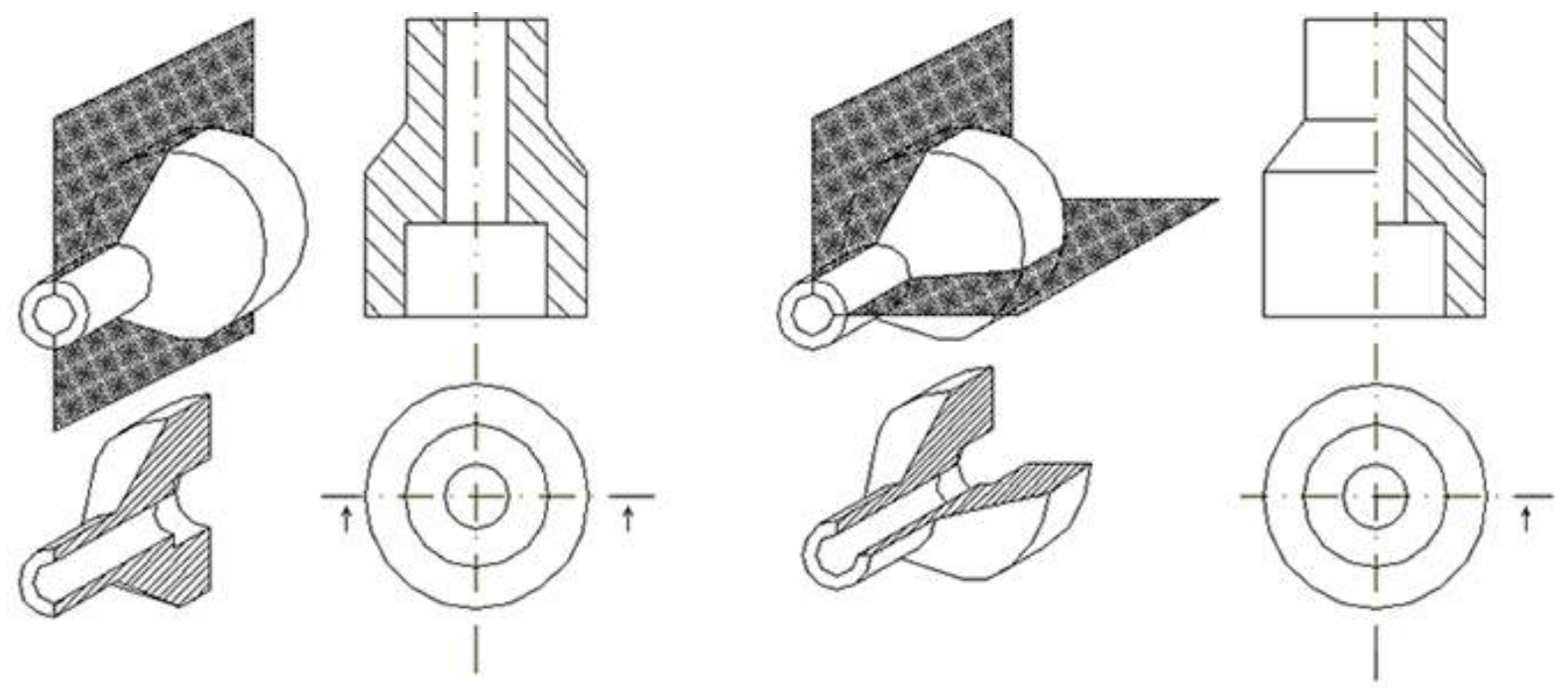
Corte em desvio: Quando o plano muda de direção para mostrar detalhes fora do eixo principal (Figura 13.12a).

Corte parcial: Representado sobre parte de uma vista, para mostrar algum detalhe interno da peça (Figura 13.12b).

Figura 13.12 - Tipos de cortes: a) Corte em desvio; b) Corte parcial.
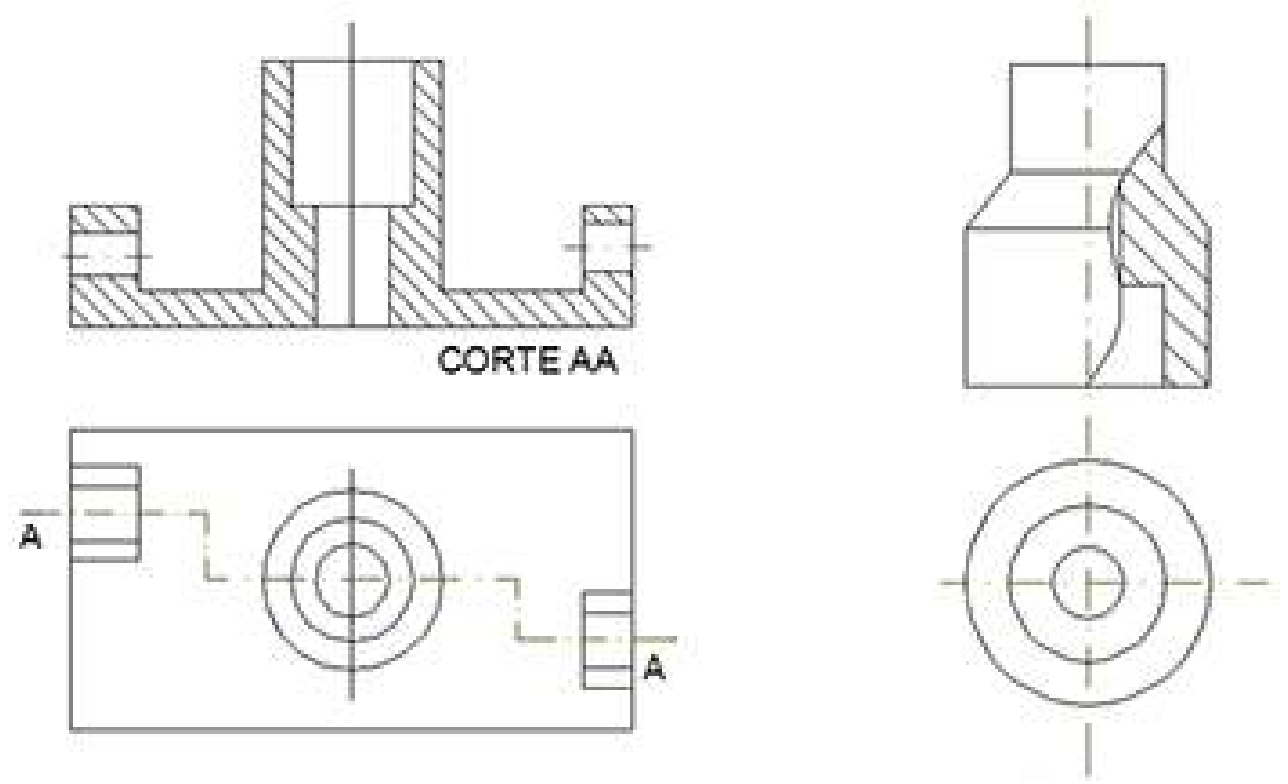

Corte rebatido: Quando o objeto possui detalhes simétricos que não passam pelo plano de corte.

Figura 13.12 - corte rebatido.

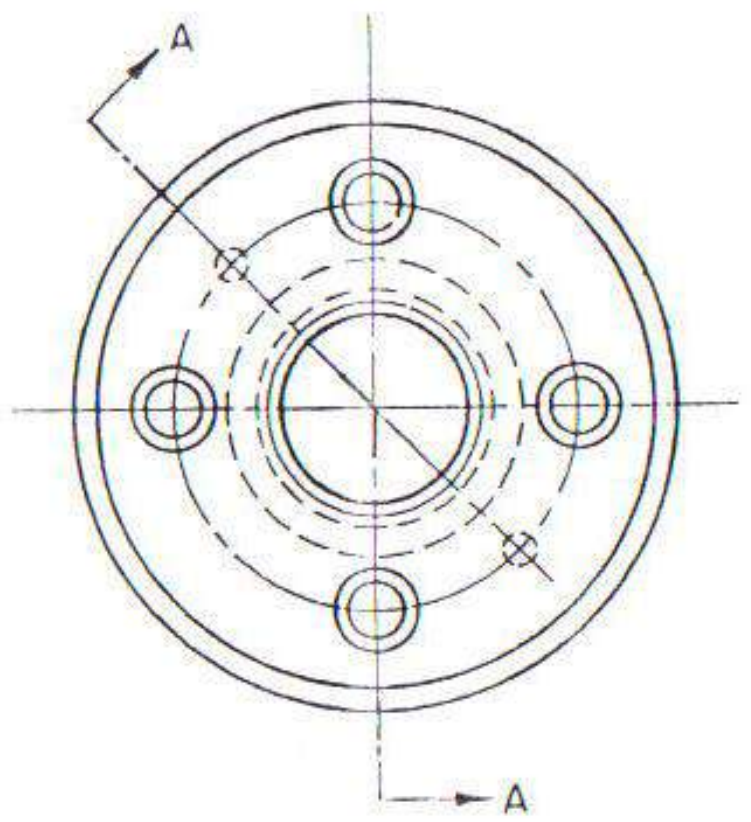


É importante destacar que em cortes, no sentido longitudinal, não são hachurados quando esses passarem por: nervuras, dentes de engrenagem, parafusos, porcas, eixos, arruelas, entre outros elementos mecânicos. Alguns exeplos serão demonstrados a seguir.

Figura 13.13 - Corte em polia onde não é hachurado o braço da polia.
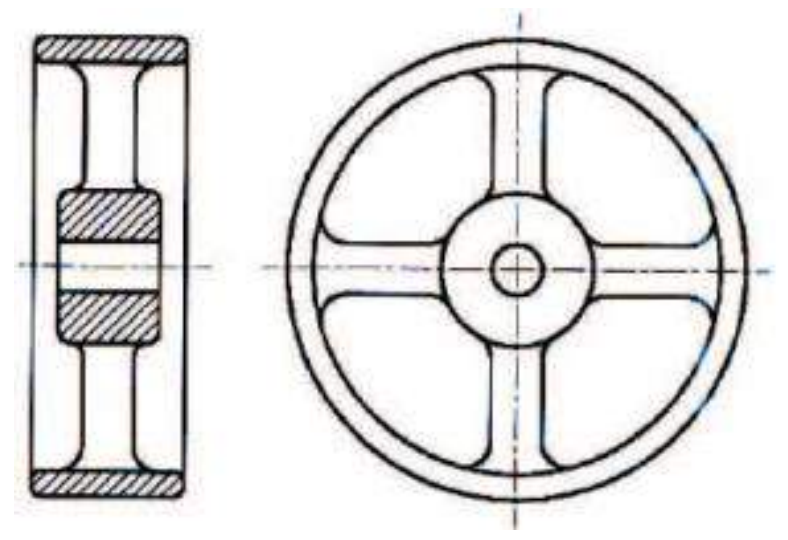

Figura 13.14 - Corte em peça com nervura
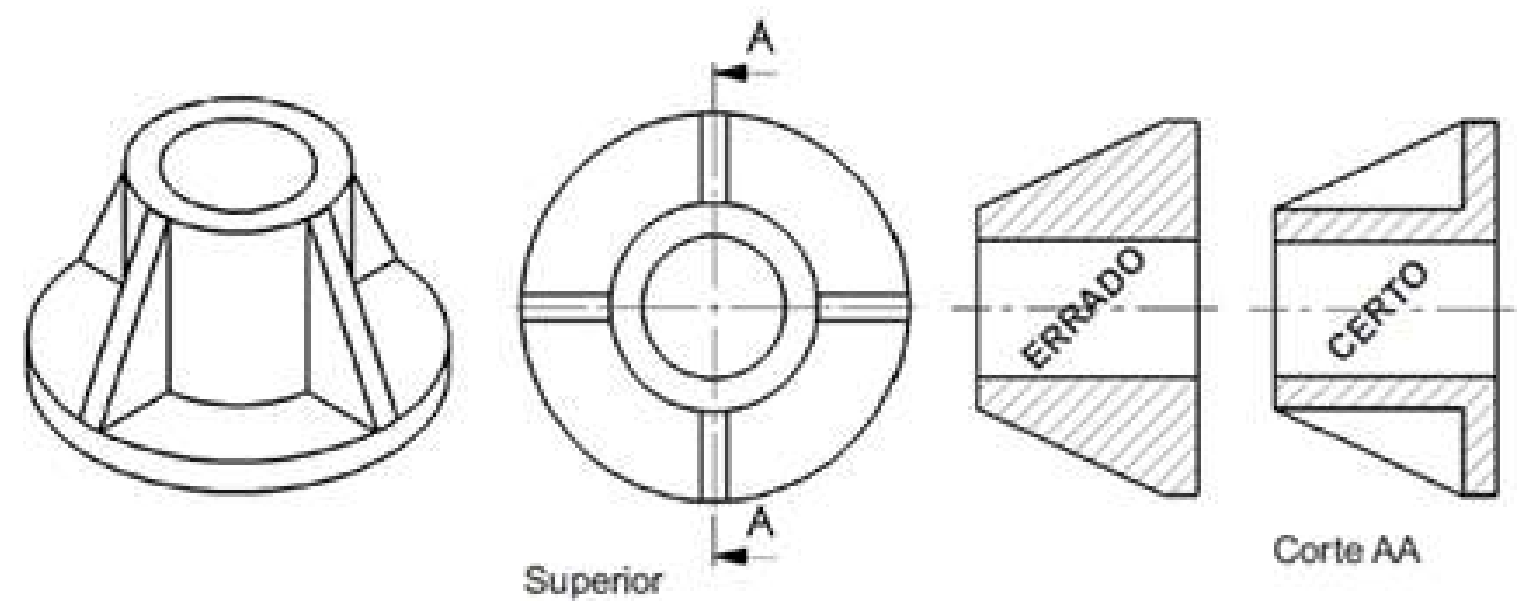

Corte AA

Figura 13.15 - Corte em parafuso (13.15a), pinos (13.15b) e rebites (13.15c)
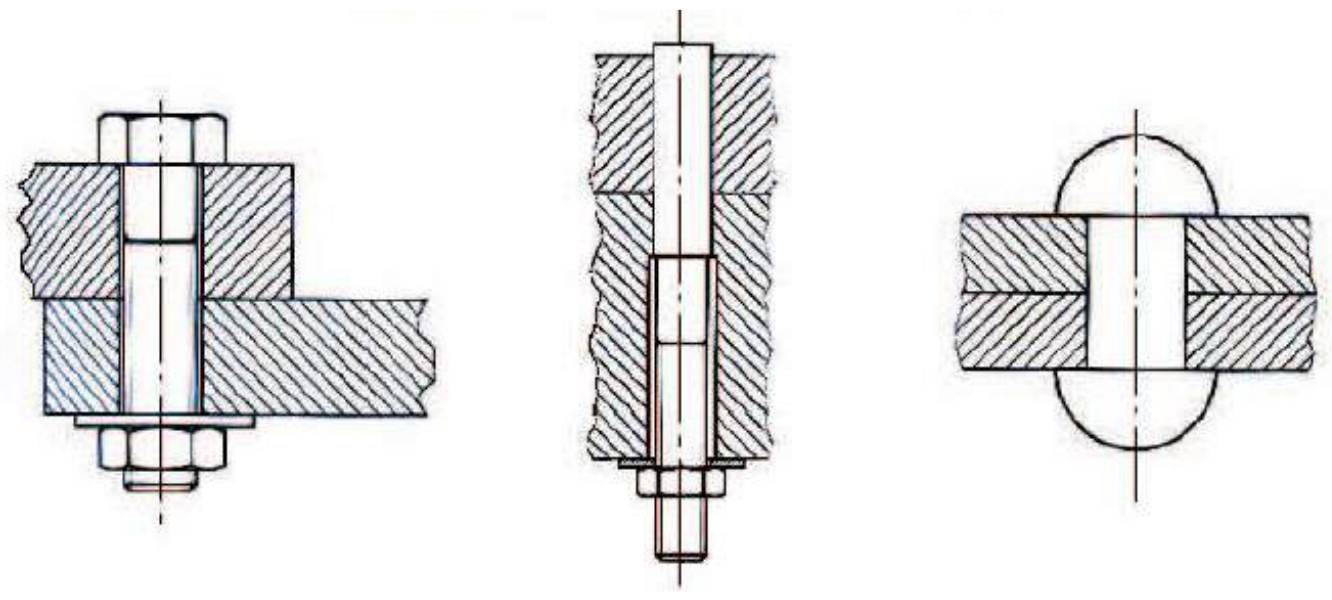


\subsection{CORTES E SEÇÕES}

Basicamente a diferença que o Corte no desenho técnio se registra tanto a interseção do plano secante como a projeção da parte visível desta, situada além deste plano (Figura 13.16a) e a Seção é representado tão somente a interseção do plano secante com o objeto (Figura 13.16b).

Figura 13.16 - Corte em peça com nervura
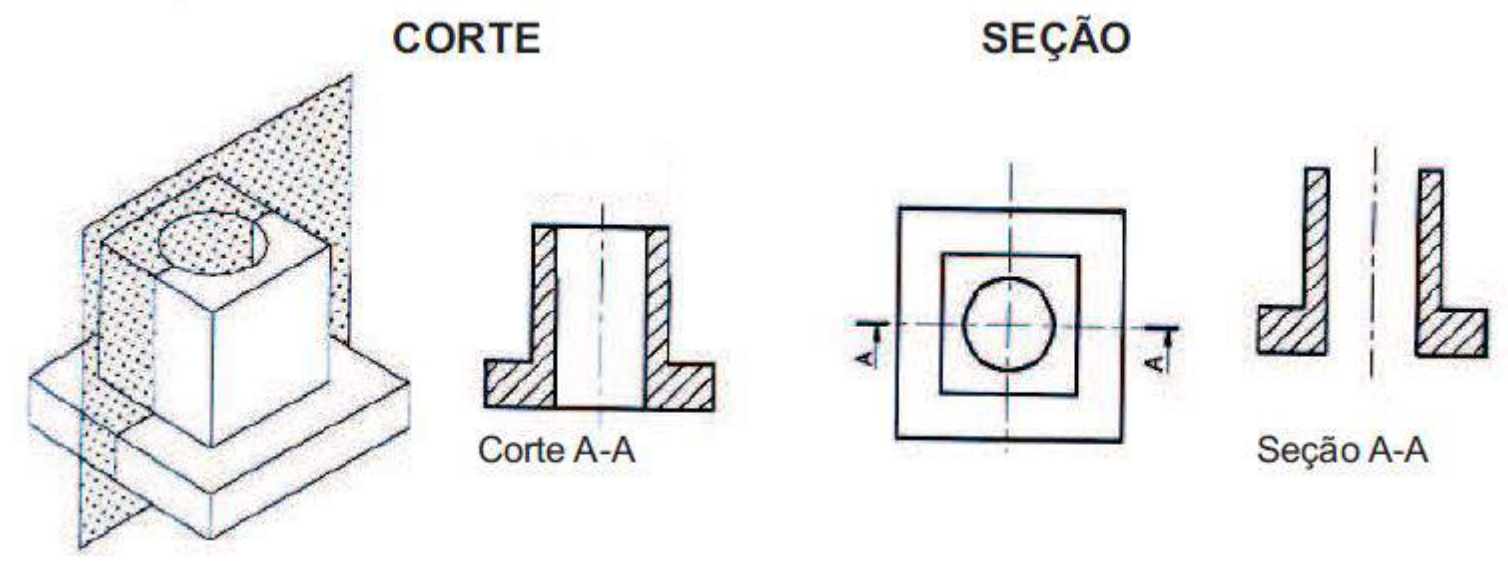

Nas vistas de seções pode ser representado não apenas como projeção da vista base, mas, sim, normal da região seccionada, conforme exposto na Figura 13.17.

Figura 13.16 - Corte em peça com nervura

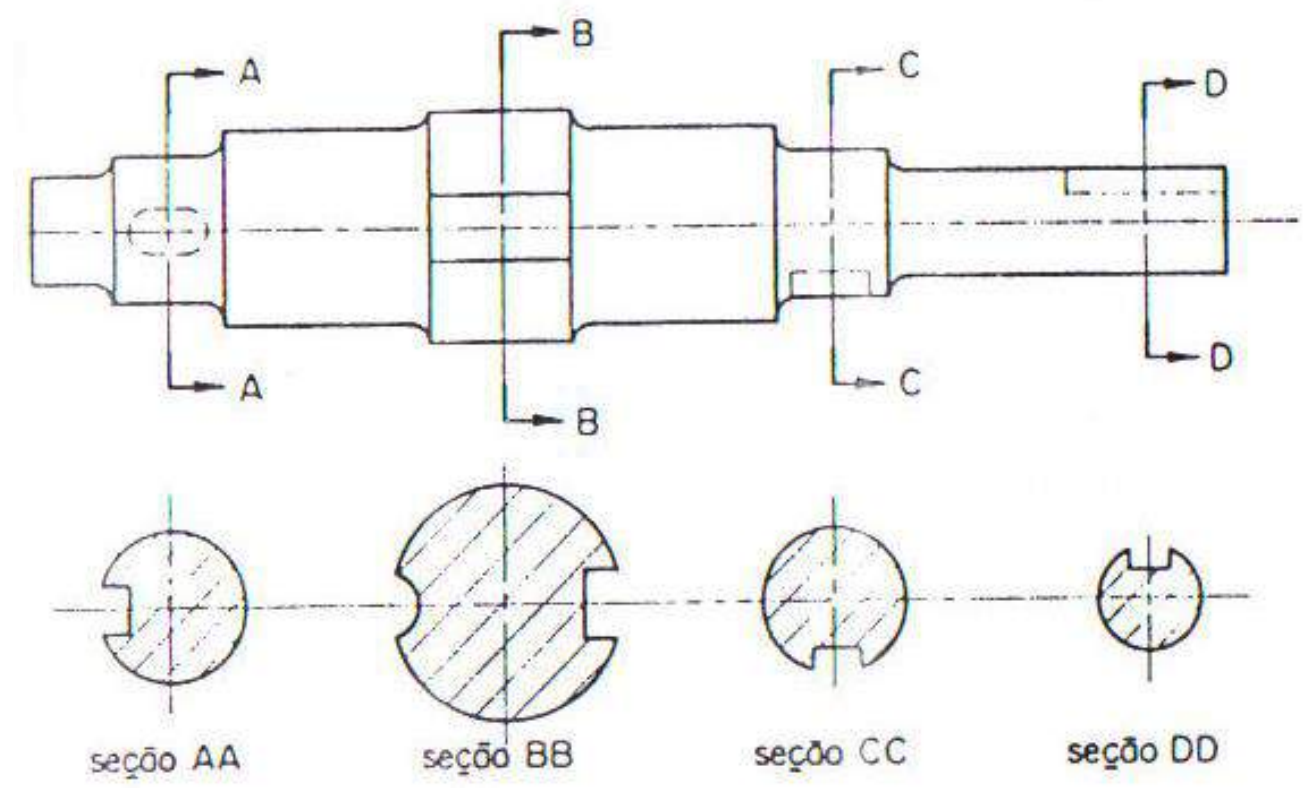

Catapan, Strobel e Santana (2020) 


\section{EXERCÍCIOS}

Exerício 1: Complete os desenhos técnicos, fazendo as hachuras nas partes maciças atingidas pelo corte.
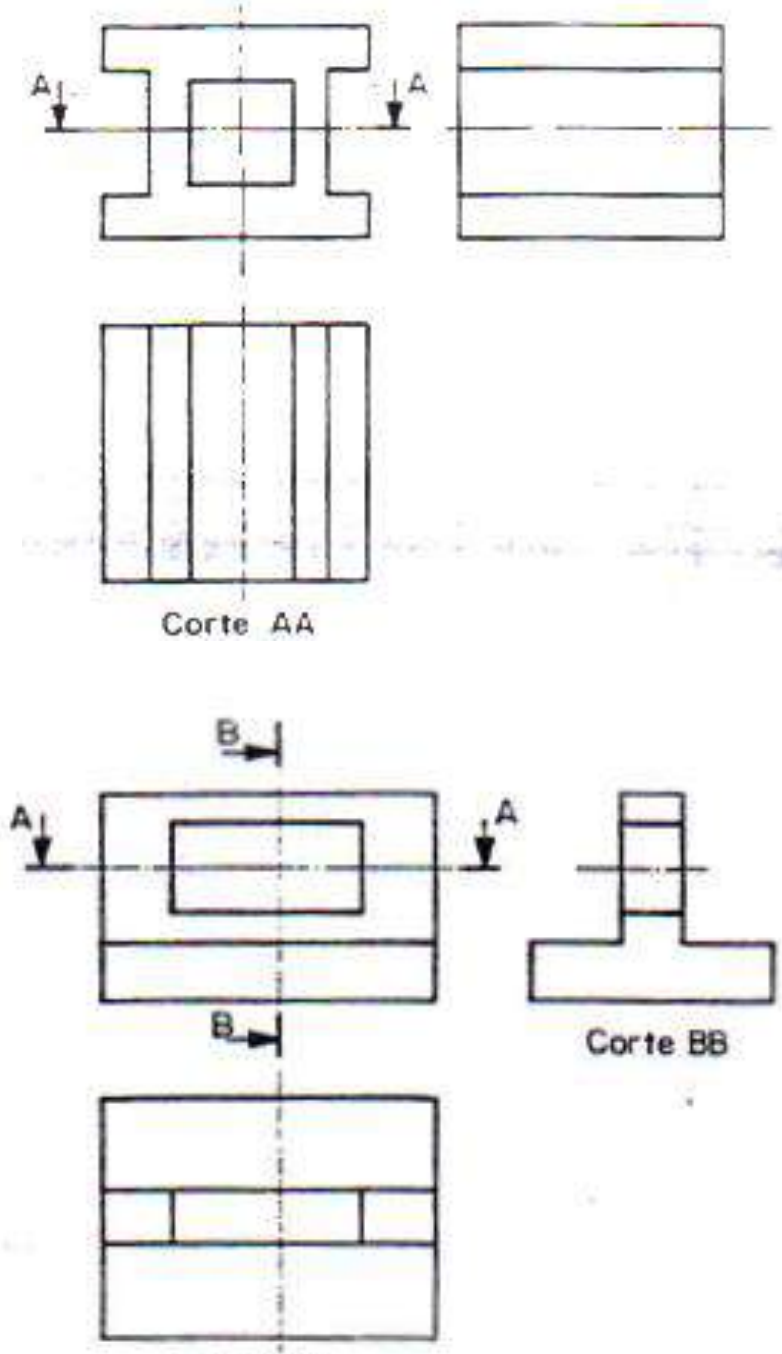

Corte AA
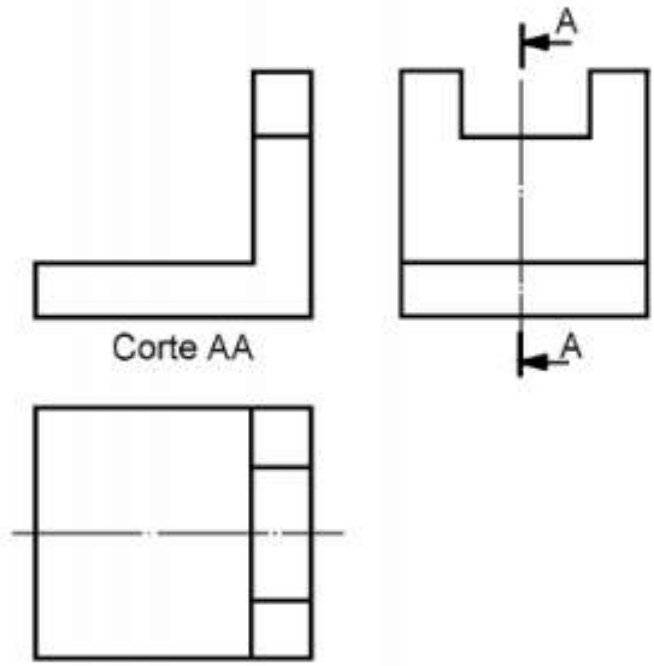

Catapan, Strobel e Santana (2020) 
Exerício 2: Analise o desenho técnico e escreva "V" para verdadeiro ou "F" para a alternativa falsa.
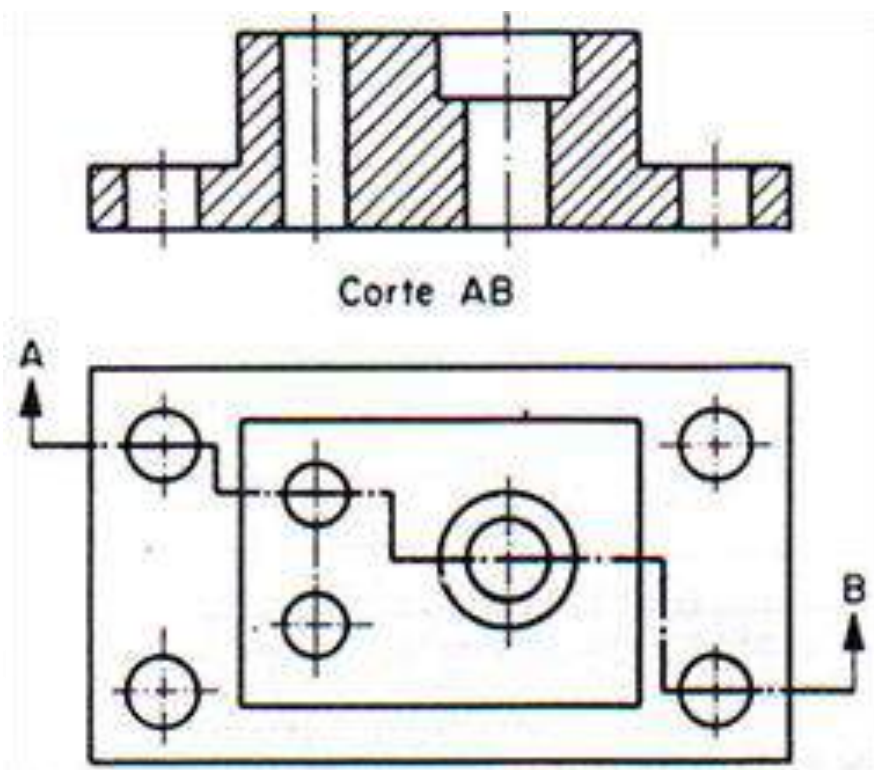

( ) O corte composto reuniu quatro cortes em apenas um.

( ) O corte composto está representado na vista superior (elevação)

( ) A perscpectiva em corte correspondente ao desenho técnico é a que está abaixo?

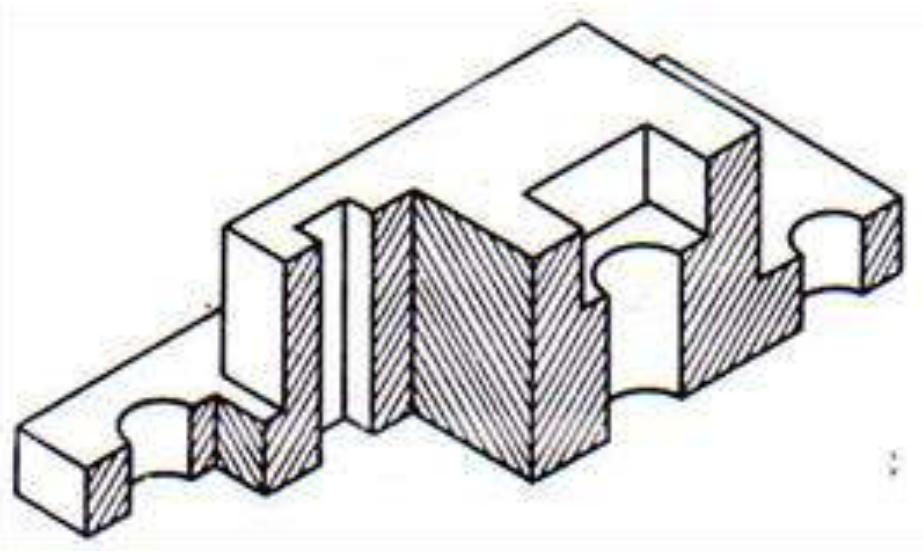




\section{EXERCÍCIOS DE CORTES}

1) Os desenhos abaixo estão sendo representados no lado esquerdo pela vista frontal e sob ela a vista superior. Do lado direto está sendo representado apenas a vista superior, com indicação de corte, e sobre ela o espaço onde a vista de corte deve ser representada. Representar os cortes indicado nos objetos dados.

a)

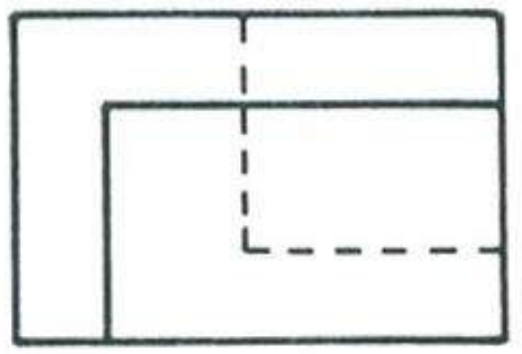

$r$

L
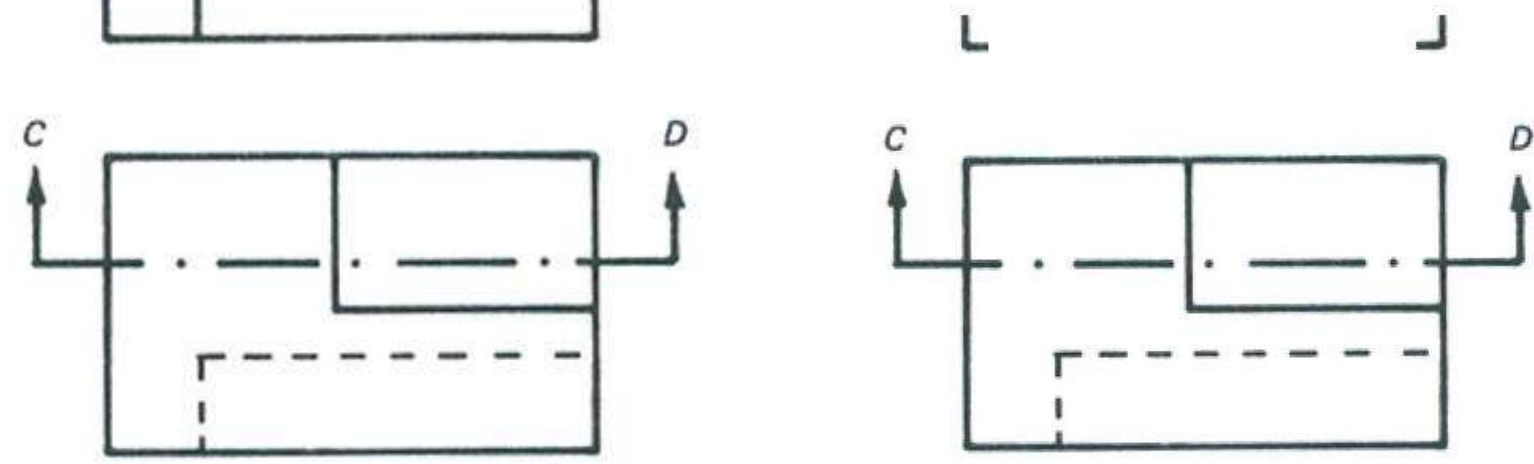

b)

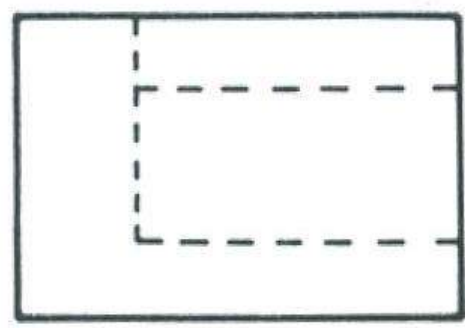

$\mathbf{r}$

フ

$\mathbf{L}$
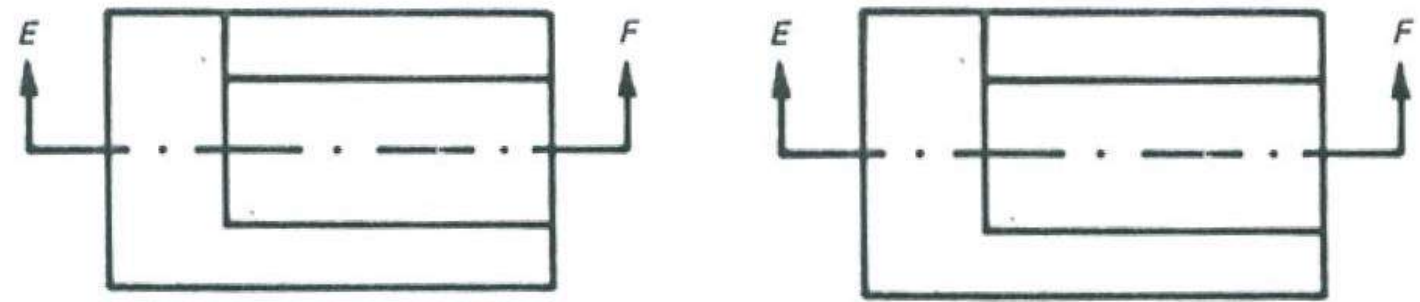

Catapan, Strobel e Santana (2020) 
c)

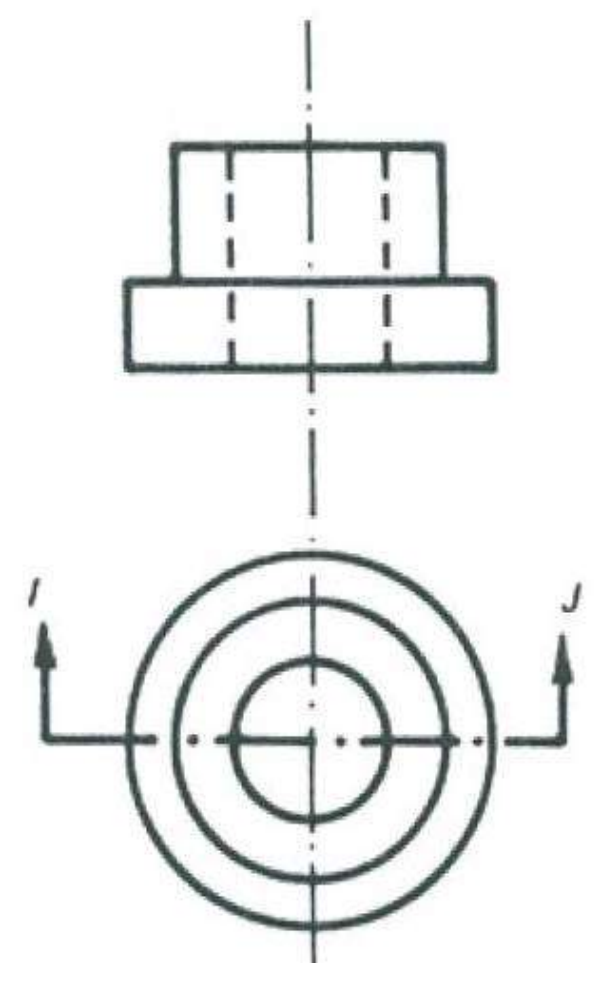

d)

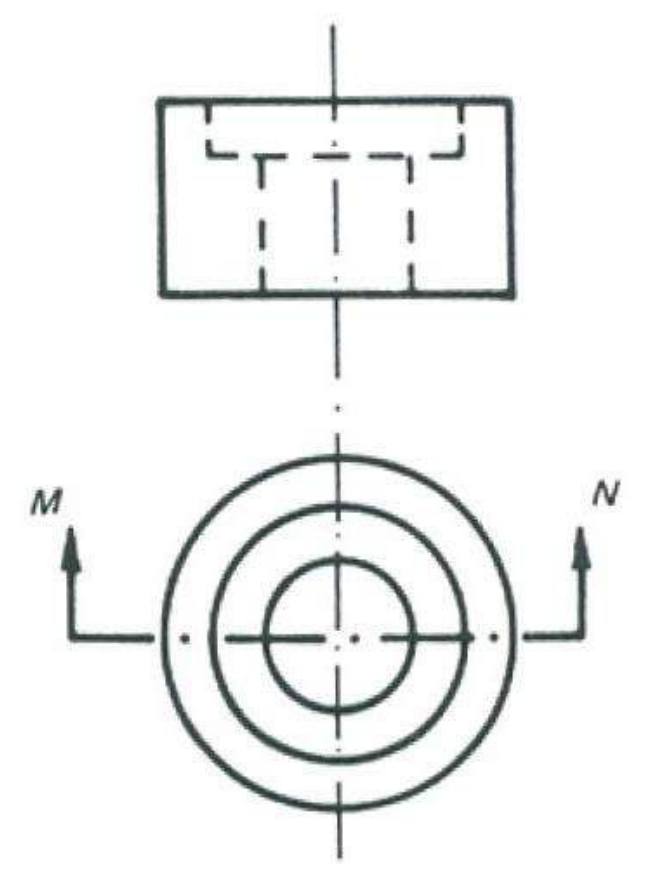

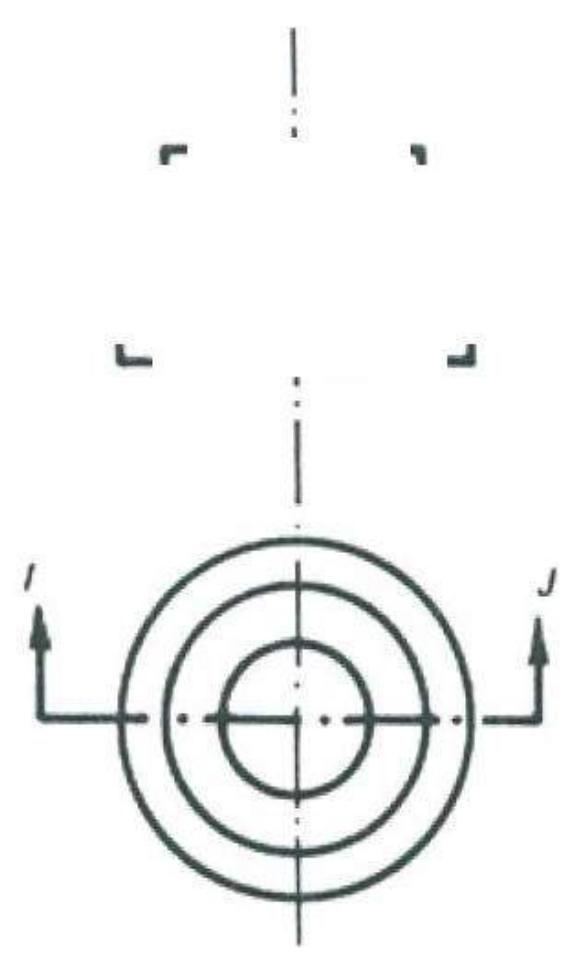
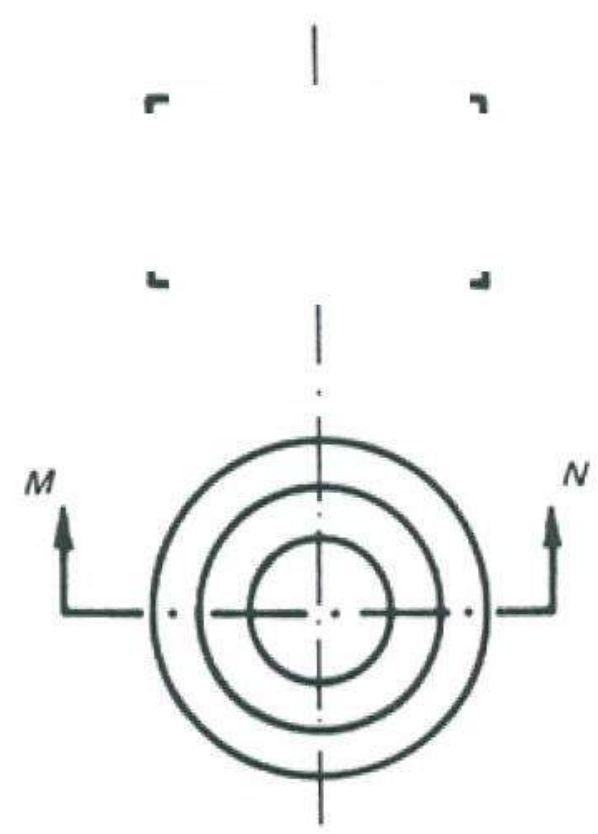
2) A Coluna "A" - são as peças representadas em perspectiva. Na Coluna B represente o sombreado das partes atingidas pelo corte. Na Coluna $\mathrm{C}-$ represente a hachura da região cortada.
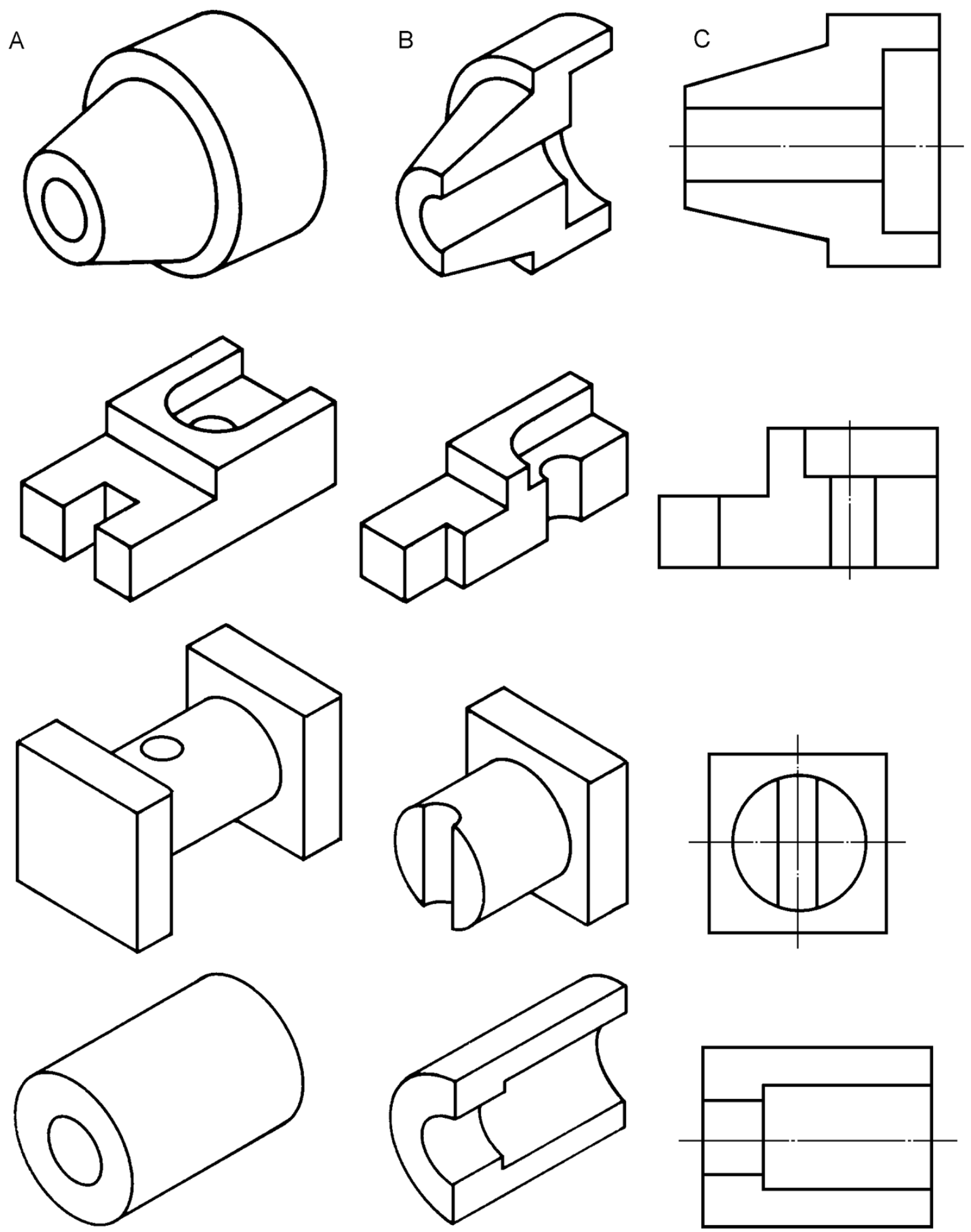
3) Indique as linhas de corte nas projeções adequadas nos desenhos abaixo.
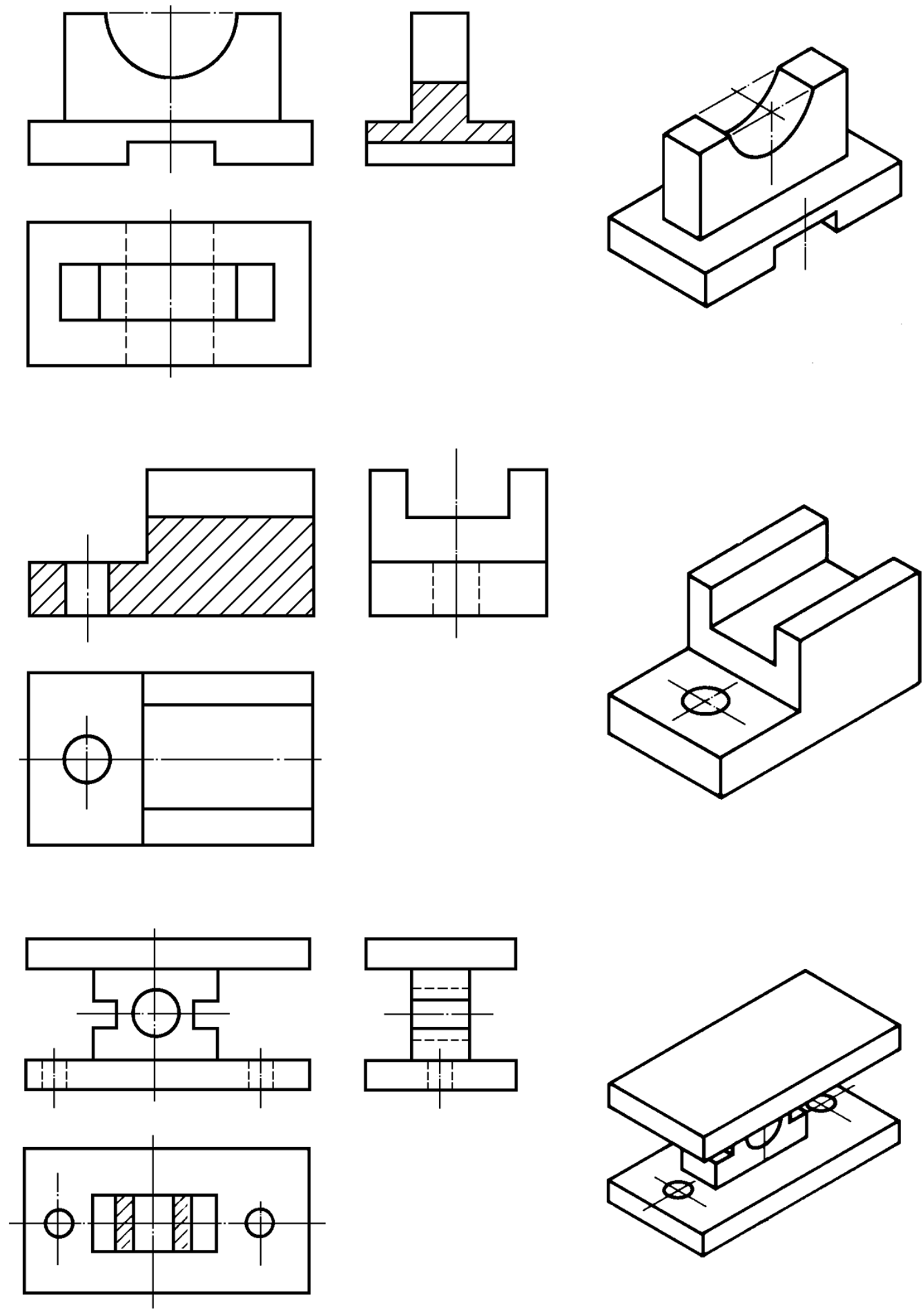
4) Representar o corte pleno e o meio corte das peças dadas, de acordo com o exemplo dado.

Exemplo:
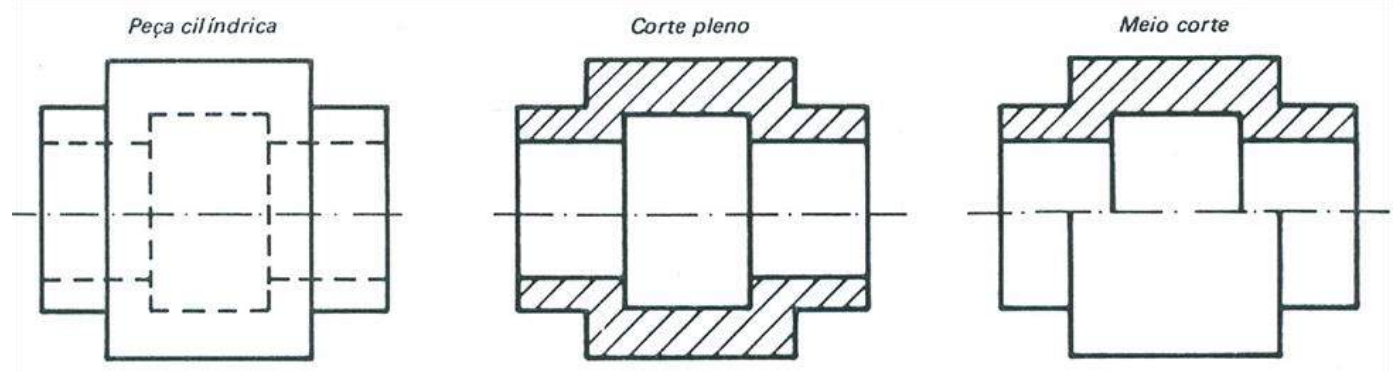

a)

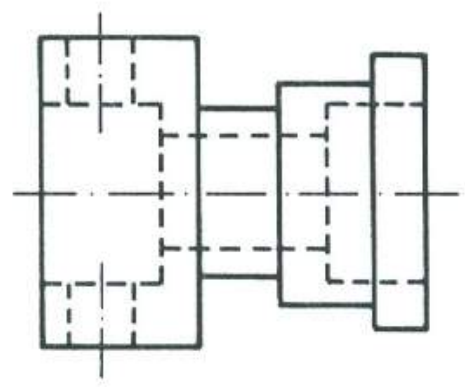<smiles>C1CCC1</smiles>
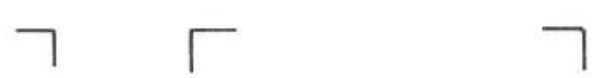

b)
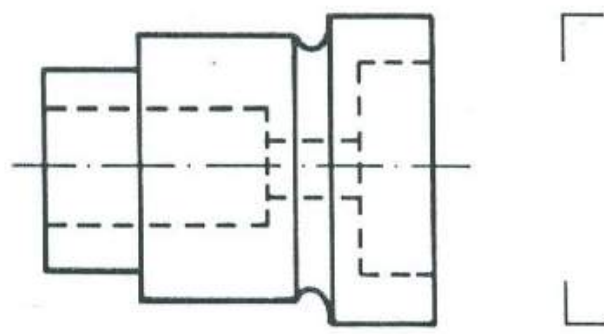

1

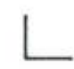

c)
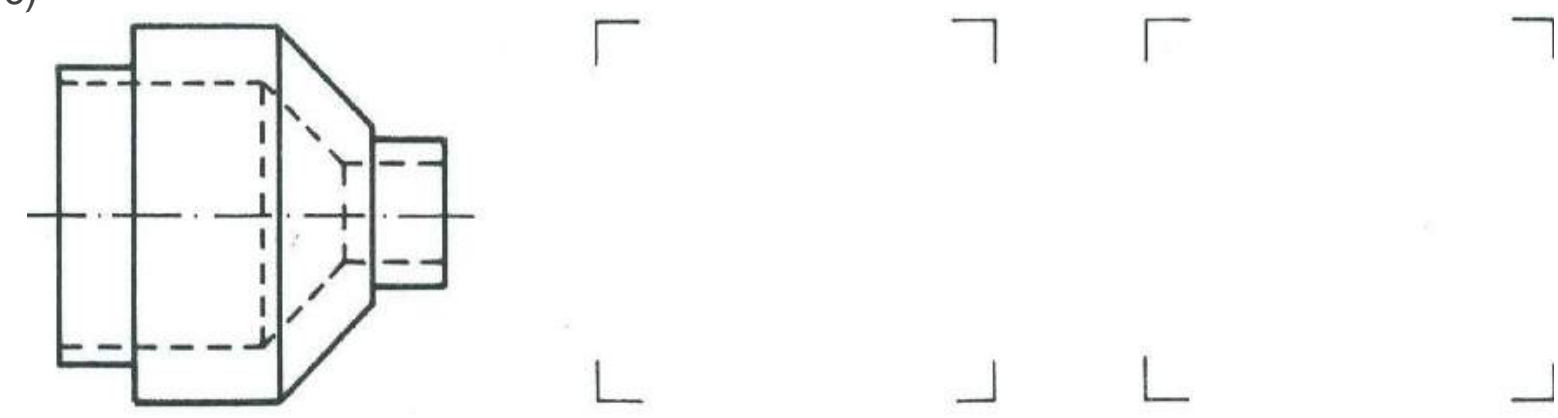
5) Nos desenhos abaixo, complete as vistas em corte e coloque as cotas.
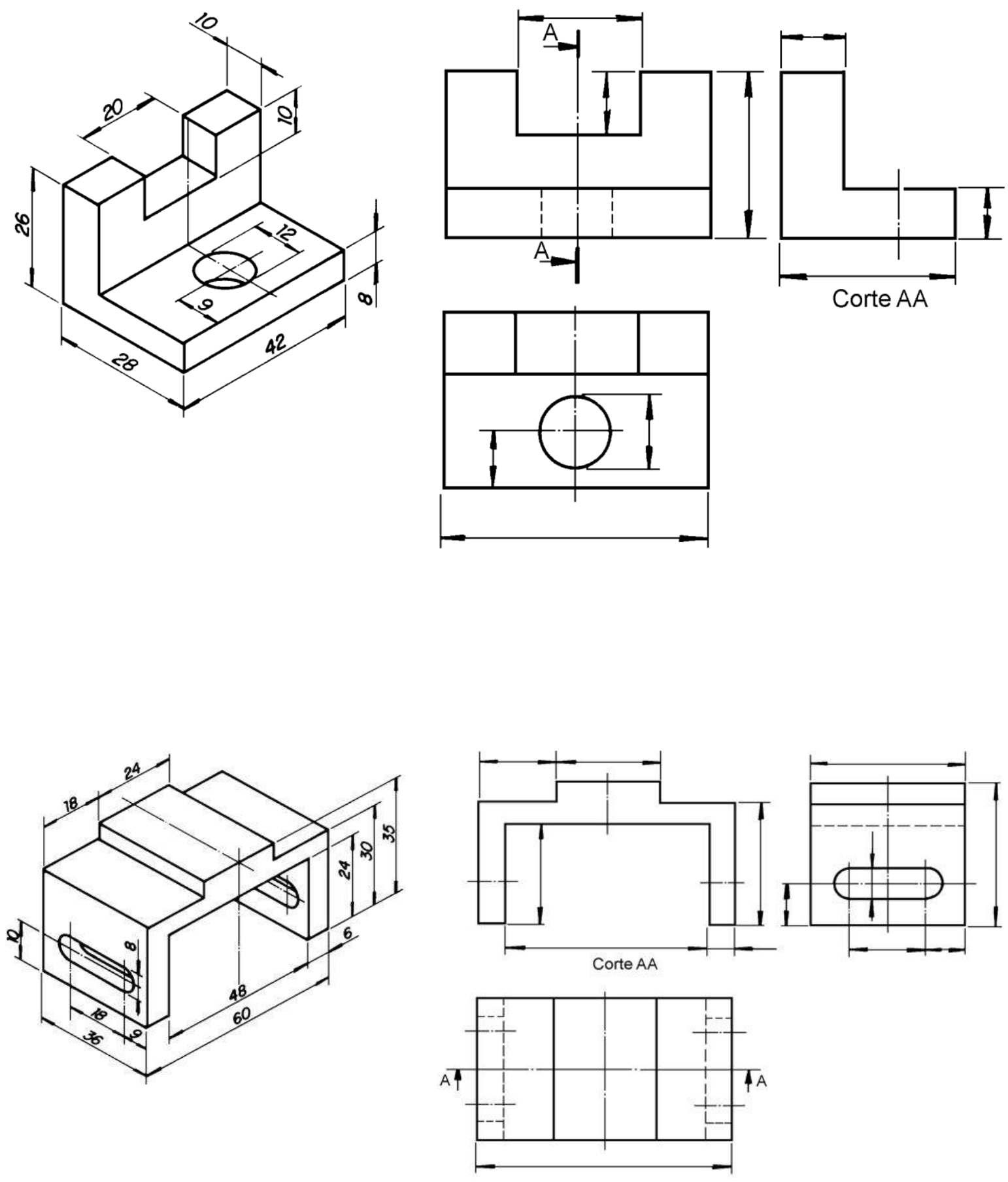
6) Representar a vista superior da peça abaixo. Trace uma linha de corte no meio da peça que passe sobre a linha de simetria/ longitudinal a peça. Represente a vista de corte, substituindo a vista frontal. Escala 1:1. Faça a cotagem nas vistas. Aplicar a Hachura de acordo com as Normas da ABNT.

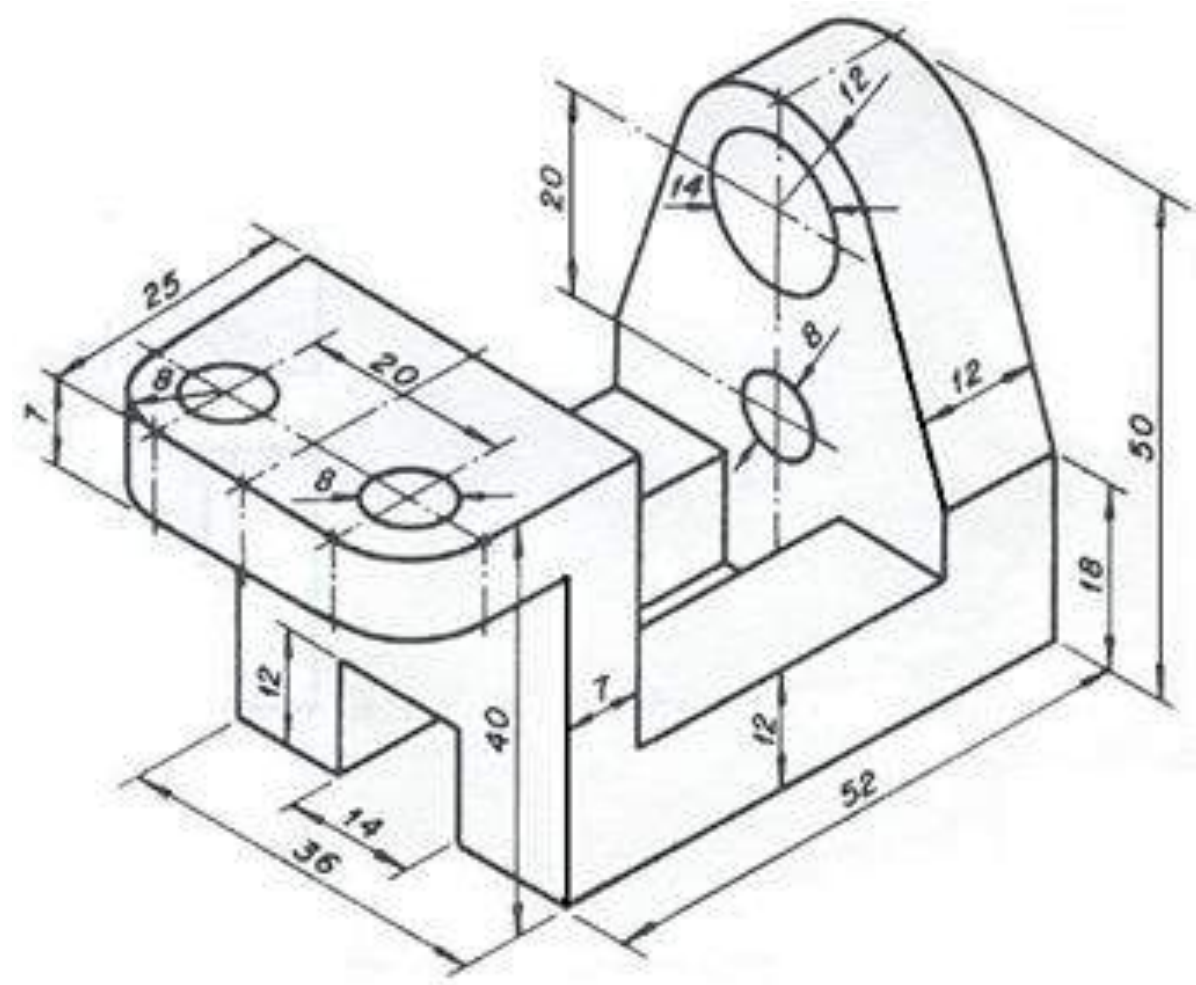


7) Representar a vista superior da peça abaixo. Trace uma linha de corte COMPOSTO sobre a vista superior, que demonstre o maior número de detalhes da peça. Represente a vista de corte, substituindo a vista frontal. Escala 1:1. Faça a cotagem nas vistas. Aplicar a Hachura de acordo com as Normas da ABNT.

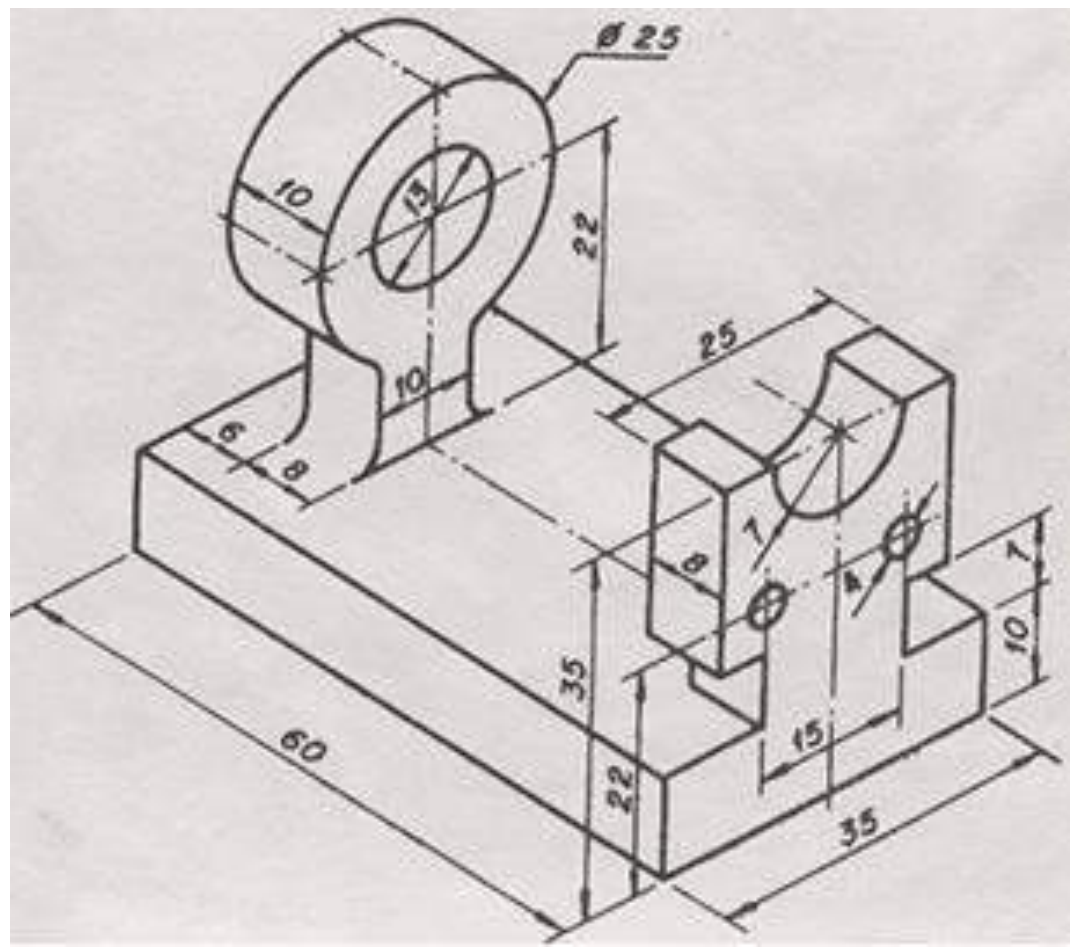


8) Representar a vista superior da peça abaixo. Trace uma linha de corte no meio da peça que passe sobre a linha de simetria/ longitudinal a peça. Represente a vista de corte, substituindo a vista frontal. Escala 1:1. Faça a cotagem nas vistas. Aplicar a Hachura de acordo com as Normas da ABNT.

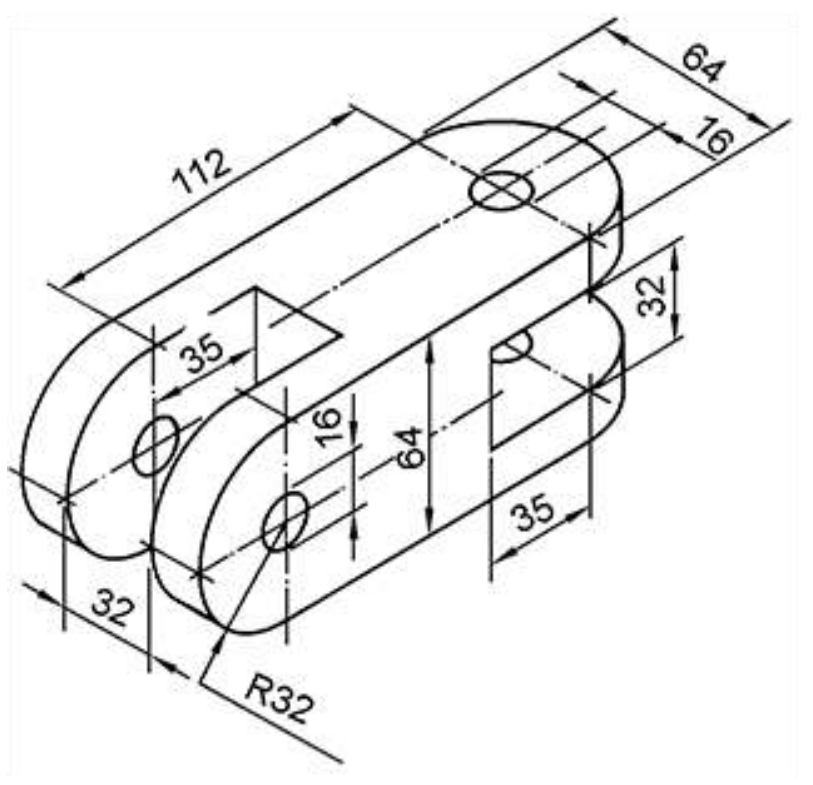


9) O desenho abaixo mostra uma perspectiva isométrica de um objeto utilizado para separar dois eixos na vertical. Para resistir a movimentações desses eixos é necessária uma nervura entre os furos. Com base nestas informações, siga:

a) Conclua o desenho da vista superior, caso necessário;

b) Indique uma linha de corte na vista superior sabendo que esta deve ser um corte total que passa pelo eixo de simetria da peça e nos centros dos furos, longitudinal a nervura;

c) Represente a Vista de Corte AA acima da vista superior. Observação: Os furos de $\varnothing 13 \mathrm{~mm}$ e ø10mm são passantes (ou seja, possuem comprimentos de $44 \mathrm{~mm}$ e $34 \mathrm{~mm}$, respectivamente);

d) Insira as cotas no desenho.

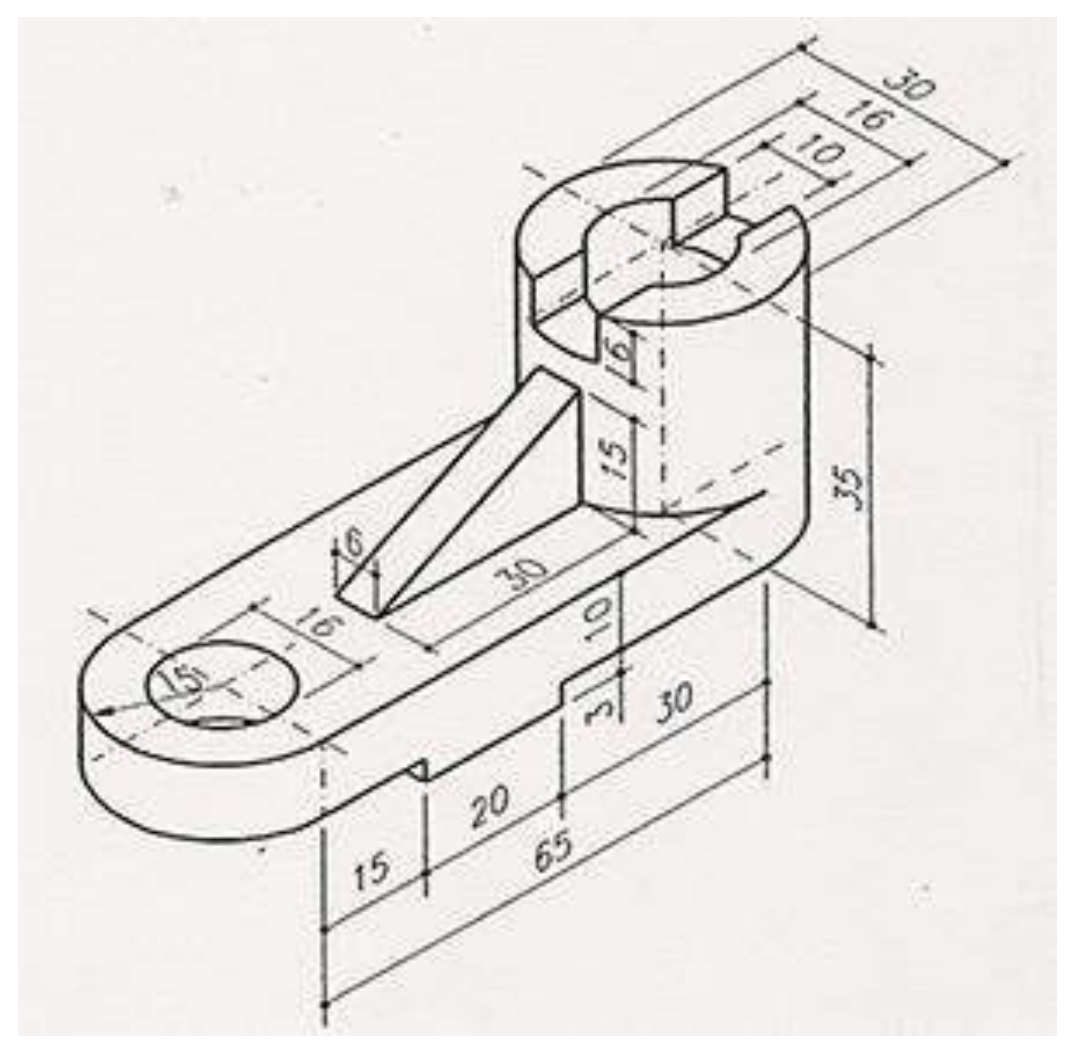


10) Representar as vistas da peça abaixo e substituir as vistas frontal pelo Corte AA, sabendo esse corte é aplicado na vista superior e deve passar pelos centros dos furos de ø20mm. Aplicar a Hachura de acordo com as Normas da ABNT.

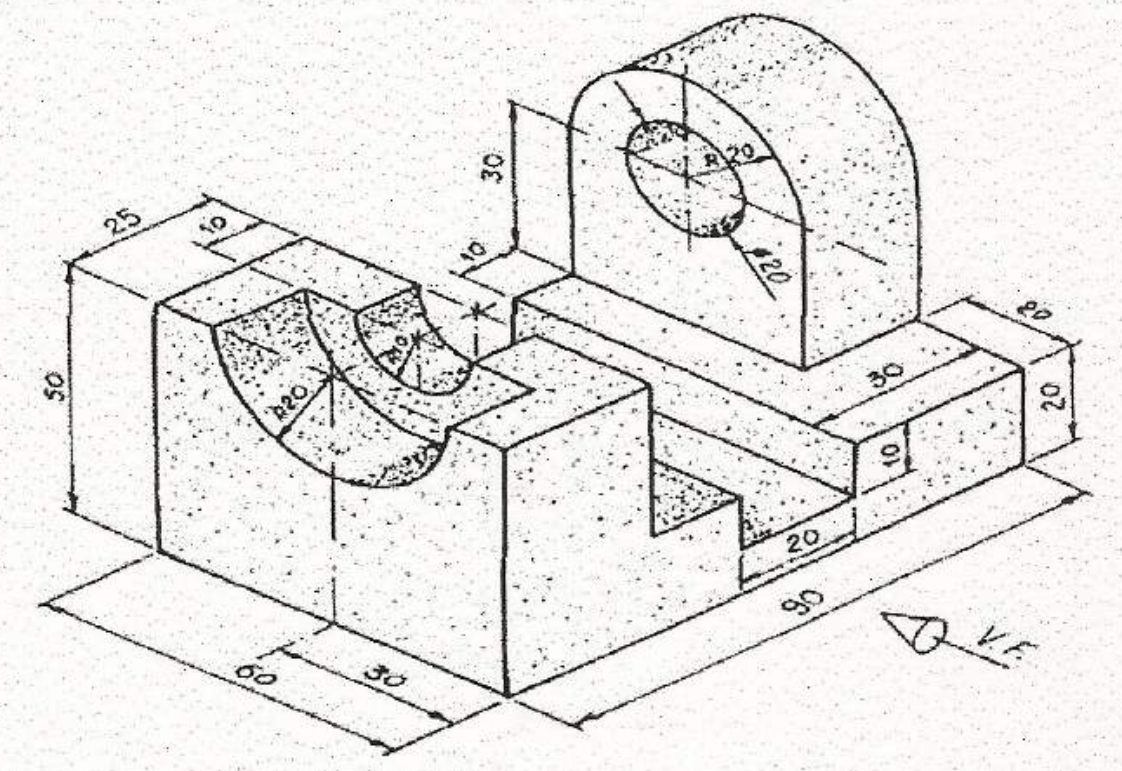


11) Sabendo que a peça não é cortada e que a representação em Perspectiva Isométrica é apenas para facilitar o entendimento da peça, desenhe a vista superior do objeto. Aplique o meio corte semelhante ao corte que está representado abaixo. Represente a vista de corte (meio corte) substituindo a vista frontal.

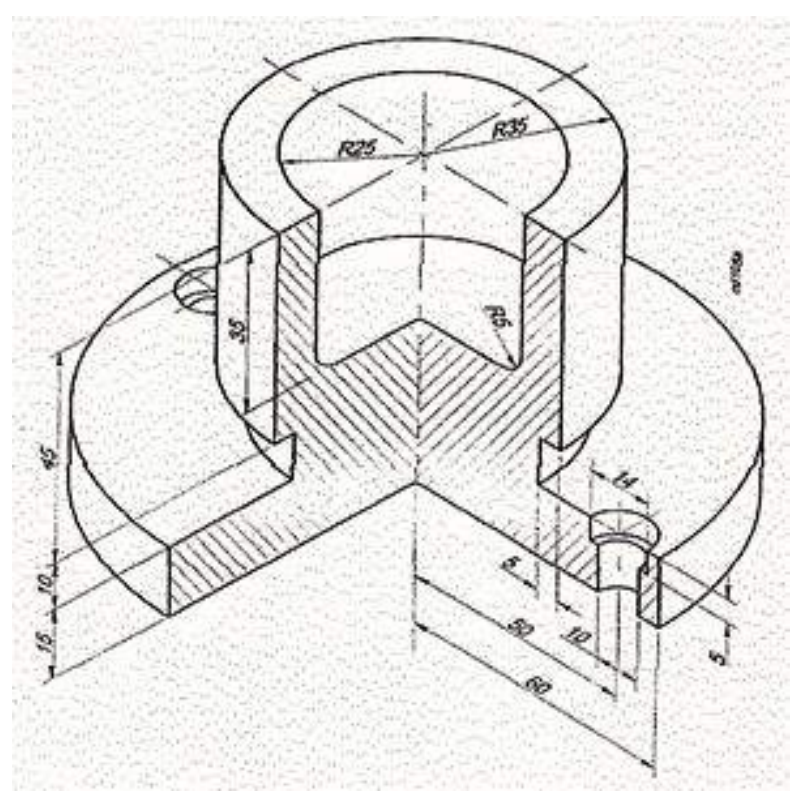




\section{REFERÊNCIAS BIBLIOGRÁFICAS}

AGOSTINHO, OSWALDO LUIZ; DOS SANTOS, ANTONIO CARLOS; LIRANI, JOÃO.

Tolerâncias, ajustes, desvios e análise de dimensões. 7.ed. São Paulo: Blücher. 2001.

OLIVEIRA, A. P., Desenho Técnico, Apostila do Instituto Técnico, 2007.

PROVENZA, F. P. - PROTEC - Desenhista de Máquinas. São Paulo. Escola PROTEC, $4^{\circ}$ Ed. 1991.

PROVENZA, F. P. - PROTEC - Projetista de Máquinas. São Paulo. Escola PROTEC, $4^{\circ}$ Ed. 1996.

SANTANA, F. E., Desenho Técnico, Apostila da Faculdade de Tecnologia em São Carlos FATESC, Rev 00, 2005.

SENAI-ES. Leitura e Interpretação de Desenho Técnico Mecânico. Vitória: Senai-ES, 1996.

SOCIESC, DES - Desenho Técnico, Apostila da Escola Técnica Tupy, Rev 00, Joinville SC. 2004. 


\section{SOBRE OS AUTORES}

Márcio Fontana Catapan: Doutor em Engenharia Mecânica pela UFPR (2014), mestre em Engenharia Mecânica pela UFSC (2006) e graduado em Engenharia Mecânica pela UP (2002). Experiência profissional como engenheiro de produtos e coordenador na área de projetos por mais de 10 anos, atuando em empresas como $\mathrm{CNHi}$, Electrolux, entre outras. Professor com experiência de 15 anos na área de projetos mecânicos em diversas universidades. Atualmente é Professor adjunto na Universidade Federal do Paraná - UFPR desde 2011 com atuação na graduação e pós-graduação. Experiência e vivência na área de desenho técnico há 20 anos.

Christian Scapulatempo Strobel: Doutor em Engenharia Mecânica (2012), mestre em Engenharia Mecânica (2007) e graduado em Engenharia Mecânica (2004), com todas as titulações na pela Pontifícia Universidade Católica do Paraná - PUC-PR. Experiência profissional como engenheiro de produtos e serviços na Electrolux $\mathrm{e}$ Trane (Ingersoll Rand), professor em diversas universidades, como PUC-PR, UP, FAE. Atualmente é Professor adjunto na Universidade Federal do Paraná - UFPR desde 2012. Experiência e vivência na área de desenho técnico há 20 anos. Escritor de livros na área da engenharia mecânica.

Fábio Evangelista Santana: Doutor em Engenharia de Produção (2017) pela UFSC com sanduíche no Instituto para Tecnologia e Trabalho da Universidade Tecnológica de Kaiserslautern, Alemanha; mestre em Engenharia Mecânica (2005) pela UFSC; graduado em Engenharia de Produção Mecânica pela USP (2002) e técnico Mecânica de Precisão pela escola SENAI Suíço-brasileira (1997). Experiência profissional como Engenheiro de Produto na Bosch Rexroth e na Embraco - SC. Desde 2009 é professor com dedicação exclusiva do Instituto Federal de Educação, Ciência e Tecnologia de Santa Catarina (IFSC), câmpus Araranguá - SC, onde atua diretamente com a disciplina de desenho técnico. Experiência e vivência na área de desenho técnico há 25 anos. Autor de outros livros na área de Desenho Assistido por Computador. 
Agência Brasileira ISBN

ISBN: 978-65-81028-06-0 